EUROPAPARLAMENTS- OG RÅDSDIREKTIV 2005/36/EF

av 7. september 2005

om godkjenning av yrkeskvalifikasjoner(*)

\section{EUROPAPARLAMENTET OG RÅDET FOR DEN EUROPEISKE UNION HAR -}

under henvisning til traktaten om opprettelse av Det europeiske fellesskap, særlig artikkel 40, artikkel 47 nr. 1, artikkel 47 nr. 2 første og tredje punktum og artikkel 55,

under henvisning til forslag fra Kommisjonen $\left({ }^{1}\right)$,

under henvisning til uttalelse fra Den europeiske økonomiske og sosiale komité $\left({ }^{2}\right)$,

etter framgangsmåten fastsatt i traktatens artikkel 251( $\left.{ }^{3}\right)$ og

ut fra følgende betraktninger:

1) I henhold til traktatens artikkel $3 \mathrm{nr} .1$ bokstav c) er fjerning av hindringer for fri bevegelighet for personer og tjenester mellom medlemsstatene ett av Fellesskapets mål. For medlemsstatenes borgere omfatter dette blant annet retten til å utøve et yrke, enten som selvstendig næringsdrivende eller som lønnsmottaker, $i$ en annen medlemsstat enn der de har tilegnet seg sine yrkeskvalifikasjoner. I tillegg fastsetter traktatens artikkel $47 \mathrm{nr}$. 1 at det skal vedtas direktiver om gjensidig godkjenning av diplomer, attester og andre kvalifikasjonsbeviser.

2) Etter Europarådets møte i Lisboa 23. og 24. mars 2000 vedtok Kommisjonen en melding om en intern markedsstrategi for tjenester særlig rettet mot å gjøre fri tjenesteyting innenfor Fellesskapet like enkelt som innenfor én medlemsstat. Etter Kommisjonens melding om de nye europeiske arbeidsmarkedene og deres åpenhet og adgang for alle borgere, gav Europarådet på sitt møte i Stockholm 23. og 24. mars 2001 Kommisjonen i oppgave å framlegge for Europarådets vårmøte i 2002 konkrete forslag til en mer ensartet, åpen og fleksibel ordning for godkjenning av kvalifikasjoner.

(*) Denne fellesskapsrettsakten, kunngjort i EUT L 255 av 30.9.2005, s. 22, er omhandlet i EØS-komiteens beslutning nr. 142/2007 av 26. oktober 2007 om endring av EØS-avtalens vedlegg VII (Gjensidig godkjennelse av yrkeskvalifikasjoner) og protokoll 37, se EØS-tillegget til Den europeiske unions tidende nr. 19, 10.4.2008, s. 70.

(1) EFT C $181 \mathrm{E}$ av 30.7 .2002 , s. 183

$\left.{ }^{2}\right)$ EUT C $61 \mathrm{E}$ av 14.3.2003, s. 67.

$\left({ }^{3}\right)$ Europaparlamentsuttalelse av 11.2.2004 (EUT C 97 av 22.4.2004, s. 230), Rådets felles holdning av 21.12.2004 (EUT C $58 \mathrm{E}$ av 8.3.2005, s. 1) og Europaparlamentets holdning av 11.5.2005 (ennå ikke offentliggjort i EUT). Rådsbeslutning av 6.6.2005.
3) Den garantien som ved dette direktiv gis personer som har tilegnet seg sine yrkeskvalifikasjoner i en medlemsstat for å få adgang til det samme yrket og utøve dette $\mathrm{i}$ en annen medlemsstat med de samme rettighetene som medlemsstatens borgere, berører ikke vandrearbeideres plikt til å oppfylle alle vilkår for likebehandling ved utøvelse som måtte være fastsatt av sistnevnte medlemsstat, under forutsetning av at disse er objektivt begrunnet og forholdsmessige.

4) For å legge forholdene til rette for fri tjenesteyting, bør det foreligge særlige regler for å utvide muligheten til å utøve yrkesvirksomhet under den opprinnelige yrkestittelen. Når det gjelder informasjonssamfunnstjenester som ytes over avstand, bør bestemmelsene i europaparlamentsog rådsdirektiv 2000/31/EF av 8. juni 2000 om visse rettslige aspekter ved informasjonssamfunnstjenester, særlig elektronisk handel, i det indre marked $\left({ }^{4}\right)$ også få anvendelse.

5) I lys av de ulike ordningene som er opprettet for midlertidig og tidvis tjenesteyting over landegrensene på den ene side og for etablering på den annen side, bør kriteriene klargjøres for å skille mellom disse to begrepene når det gjelder tjenesteyterens bevegelighet til vertsstatens territorium.

6) Tilrettelegging av tjenesteyting må sikres samtidig som det tas behørig hensyn til offentlig helse og sikkerhet samt forbrukervern. Derfor bør det planlegges særlige bestemmelser for lovregulerte yrker som har innvirkning på offentlig helse eller sikkerhet, og som midlertidig eller tidvis yter tjenester over landegrensene.

7) Vertsstater kan, der det er nødvendig og i samsvar med fellesskapsretten, fastsette krav til erklæringer. Disse kravene bør ikke føre til en uforholdsmessig byrde for tjenesteytere eller hindre eller gjøre utøvelsen av friheten til å yte tjenester mindre attraktiv. Behovet for slike krav bør gjennomgås regelmessig i lys av framdriften $\mathrm{i}$ arbeidet med å opprette en fellesskapsramme for administrativt samarbeid mellom medlemsstatene.

$\overline{\left({ }^{4}\right)} \quad$ EFT L 178 av 17.7 .2000$, s. 1. 
8) Tjenesteyteren bør omfattes av disiplinære regler i vertsstaten som har en direkte og særlig sammenheng med yrkeskvalifikasjonene, som for eksempel definisjonen av yrket, omfanget av den virksomhet som omfattes av yrket eller som er forbeholdt yrket, bruken av titler samt alvorlig yrkesmessig forsømmelse som er direkte og

9) Samtidig som det for etableringsadgangen opprettholdes de prinsipper og garantier som ligger til grunn for de ulike gjeldende ordningene for godkjenning, bør reglene for slike ordninger forbedres i lys av den erfaring som gjøres. Dessuten er berørte direktiver endret ved flere anledninger, og bestemmelsene i disse direktivene bør omorganiseres og forenkles ved at de anvendte prinsippene gjøres mer ensartede. Det er derfor nødvendig å erstatte rådsdirektiv 89/48/EØF( $\left.{ }^{1}\right)$ og 92/51/EØF( $\left.{ }^{2}\right)$, og dessuten europaparlaments- og rådsdirektiv 1999/42/ $\left.\mathrm{EF}^{3}\right)$ om den generelle ordningen for godkjenning av yrkeskvalifikasjoner samt rådsdirektiv 77/452/EØF $\left(^{4}\right)$, 77/453/EØF( $\left.{ }^{5}\right), 78 / 686 / \mathrm{E} Ø \mathrm{~F}\left({ }^{6}\right), 78 / 687 / \mathrm{E} \varnothing \mathrm{F}\left({ }^{7}\right), 78 / 1026 /$ $\mathrm{E} \varnothing \mathrm{F}\left({ }^{8}\right), 78 / 1027 / \mathrm{E} \varnothing \mathrm{F}\left({ }^{9}\right), 80 / 154 / \mathrm{E} \varnothing \mathrm{F}\left({ }^{10}\right), 80 / 155 / \mathrm{E} \varnothing \mathrm{F}\left({ }^{11}\right)$, $85 / 384 / \mathrm{E} \emptyset \mathrm{F}\left({ }^{12}\right), 85 / 432 / \mathrm{E} \varnothing \mathrm{F}\left({ }^{13}\right), 85 / 433 / \mathrm{E} Ø \mathrm{~F}\left({ }^{14}\right) \operatorname{og} 93 / 16 /$ $\mathrm{E} Ø \mathrm{~F}\left({ }^{15}\right)$ om yrkene sykepleier med ansvar for alminnelig sykepleie, tannlege, veterinær, jordmor, arkitekt, farmasøyt og lege, og samle dem i en enkelt tekst. særlig knyttet til forbrukervern og -sikkerhet.

seg utenfor Den europeiske unions territorium. All godkjenning bør i alle tilfeller oppfylle minstekrav til utdanning for visse yrker.

11) Når det gjelder yrker som omfattes av den generelle ordningen for godkjenning av kvalifikasjoner, heretter kalt «den generelle ordningen», bør medlemsstatene beholde retten til å fastsette et minstenivå med hensyn til de kvalifikasjoner som kreves for å sikre kvaliteten på de tjenestene som ytes på medlemsstatens territorium. Imidlertid bør medlemsstatene i henhold til traktatens artikkel 10, 39 og 43 ikke pålegge en borger $\mathrm{i}$ en medlemsstat å tilegne seg de kvalifikasjoner som hovedsakelig fastsettes bare ved å henvise til diplomer utstedt $\mathrm{i}$ henhold til statenes nasjonale utdanningssystem, dersom personen allerede helt eller delvis har tilegnet seg disse kvalifikasjonene i en annen medlemsstat. Som følge av dette bør det fastsettes at enhver vertsstat der et yrke er lovregulert, må ta hensyn til de kvalifikasjonene som er tilegnet $i$ en annen medlemsstat og vurdere om disse svarer til de kvalifikasjonene medlemsstaten krever. Den generelle ordningen for godkjenning hindrer imidlertid ikke at en medlemsstat stiller særskilte krav til en person som utøver et yrke på medlemsstatens territorium på grunn av anvendelsen av regler for yrkesutøvelse begrunnet $\mathrm{i}$ allmennhetens interesse. Slike regler kan for eksempel gjelde organiseringen av yrket, yrkesstandarder, herunder yrkesetiske regler, kontroll og ansvar. Endelig er ikke formålet med dette direktiv å gripe inn i medlemsstatenes berettigede interesse $\mathrm{i}$ å hindre at noen av deres borgere forsøker å omgå nasjonal yrkeslovgivning.

10) Dette direktiv skaper ingen hindring for medlemsstatenes mulighet til, i samsvar med egne regler, å godkjenne yrkeskvalifikasjoner som tredjestatsborgere har tilegnet

( $\left.{ }^{1}\right)$ EFT L 19 av 24.1.1989, s. 16. Direktivet endret ved europaparlaments- og rådsdirektiv 2001/19/EF (EFT L 206 av 31.7.2001, s. 1).

(2) EFT L 209 av 24.7.1992, s. 25. Direktivet sist endret ved kommisjonsvedtak 2004/108/EF (EUT L 32 av 5.2.2004, s. 15).

$\left(^{3}\right)$ EFT L 201 av 31.7.1999, s. 77.

$\left({ }^{4}\right)$ EFT L 176 av 15.7.1977, s. 1. Direktivet sist endret ved tiltredelsesakten av 2003

${ }^{5}$ ) EFT L 176 av 15.7.1977, s. 8. Direktivet sist endret ved direktiv 2001/19/ EF.

$\left.{ }^{(}{ }^{6}\right)$ EFT L 233 av 24.8.1978, s. 1. Direktivet sist endret ved tiltredelsesakten av 2003.

(7) EFT L 233 av 24.8.1978, s. 10. Direktivet sist endret ved tiltredelsesakten av 2003.

$\left.{ }^{8}\right)$ EFT L 362 av 23.12.1978, s. 1. Direktivet sist endret ved direktiv 2001/19/ EF.

$\left({ }^{9}\right)$ EFT L 362 av 23.12.1978, s. 7. Direktivet sist endret ved direktiv 2001/19/ EF.

$\left({ }^{10}\right)$ EFT L 33 av 11.2.1980, s. 1. Direktivet sist endret ved tiltredelsesakten av 2003.

(11) EFT L 33 av 11.2.1980, s. 8. Direktivet sist endret ved direktiv 2001/19/EF

$\left.{ }^{12}\right)$ EFT L 223 av 21.8.1985, s. 15. Direktivet sist endret ved tiltredelsesakten av 2003.

(13) EFT L 253 av 24.9.1985, s. 34. Direktivet sist endret ved direktiv 2001/19 EF.

(14) EFT L 253 av 24.9.1985, s. 37. Direktivet sist endret ved tiltredelsesakten av 2003.

$\left.{ }^{15}\right)$ EFT L 165 av 7.7.1993, s. 1. Direktivet sist endret ved europaparlamentsog rådsforordning (EF) nr. 1882/2003 (EUT L 284 av 31.10.2003, s. 1).
12) Dette direktiv omhandler medlemsstatenes godkjenning av yrkeskvalifikasjoner ervervet $\mathrm{i}$ andre medlemsstater. Det omhandler imidlertid ikke medlemsstatenes godkjenning av vedtak om godkjenning som andre medlemsstater har gjort i henhold til dette direktiv. Følgelig kan en person som innehar yrkeskvalifikasjoner som er godkjent $i$ henhold til dette direktiv, ikke benytte en slik godkjenning til å oppnå andre rettigheter i sin hjemstat enn dem som følger av den yrkeskvalifikasjonen personen har tilegnet seg i hjemstaten, med mindre vedkommende kan godtgjøre å ha tilegnet seg ytterligere yrkeskvalifikasjoner i vertsstaten.

13) For å fastsette ordningen for godkjenning i henhold til den generelle ordningen, bør de ulike nasjonale utdannings- og opplæringsordningene inndeles i ulike nivåer. Disse nivåene, som er fastsatt bare for at den generelle ordningen skal fungere, berører verken de nasjonale utdannings- og opplæringsstrukturene eller medlemsstatenes kompetanse på dette området. 
14) Ordningen for godkjenning som er fastsatt ved direktiv 89/48/EØF og 92/51/EØF, endres ikke. Følgelig bør innehaveren av et diplom som dokumenterer en bestått utdanning av minst ett års varighet ut over videregående opplæring, kunne tillates adgang til et lovregulert yrke i en medlemsstat der slik adgang forutsetter at utøveren er innehaver av et diplom som dokumenterer en bestått høyskole- eller universitetsutdanning av fire års varighet, uansett hvilket nivå diplomet som kreves tilhører i vertsstaten. Motsatt gjelder at der adgang til et lovregulert yrke forutsetter en høyskole- eller universitetsutdanning på mer enn fire år, bør slik adgang bare tillates for innehavere av et diplom som dokumenterer en bestått høyskole- eller universitetsutdanning av minst tre års varighet.

15) I mangel av harmonisering av minstekrav til utdanning for adgang til de yrker som omfattes av den generelle ordningen, bør vertsstaten kunne innføre et utligningstiltak. Dette tiltaket skal være forholdsmessig og særlig ta hensyn til søkerens yrkeserfaring. Erfaringen viser at et krav om at vandrearbeideren skal velge mellom en egnethetsprøve og en prøveperiode, gir tilstrekkelige garantier med hensyn til søkerens kvalifikasjonsnivå, slik at et eventuelt unntak fra denne valgmuligheten i hvert enkelt tilfelle bør være begrunnet av et ufravikelig krav i allmennhetens interesse.

16) For å fremme fri bevegelighet for fagfolk, og samtidig sikre et tilstrekkelig kvalifikasjonsnivå, bør ulike yrkessammenslutninger og -organisasjoner eller medlemsstater kunne foreslå felles plattformer på europeisk plan. Det bør på visse vilkår og i samsvar med medlemsstatenes myndighet til å fastsette de kvalifikasjoner som kreves for utøvelse av yrker på deres territorium, samt innholdet i og organiseringen av medlemsstatenes ordninger for utdanning og yrkesrettet opplæring, og i samsvar med fellesskapsretten, særlig på området konkurranse, tas hensyn til disse initiativene $\mathrm{i}$ dette direktiv, og i denne sammenheng fremmes en mer automatisk form for godkjenning under den generelle ordningen. Yrkessammenslutninger som er i en slik stilling at de kan legge fram felles plattformer, bør være representative på nasjonalt på europeisk plan. En felles plattform er et sett av kriterier som gjør det mulig å kompensere for de vesentligste ulikhetene som er påvist i opplæringskravene i minst to tredeler av medlemsstatene, herunder alle medlemsstater som regulerer dette yrket. Disse kriteriene kan for eksempel omfatte krav som tilleggsopplæring, en praktisk prøveperiode under tilsyn, en egnethetsprøve eller et fastsatt minstenivå for yrkespraksis, eller kombinasjoner av disse.
17) For å ta hensyn til alle situasjoner der det fremdeles ikke finnes bestemmelser om godkjenning av yrkeskvalifikasjoner, bør den generelle ordningen utvides til de tilfeller som ikke omfattes av en særskilt ordning, enten fordi yrket ikke omfattes av noen av disse ordningene eller fordi søkeren, selv om yrket omfattes av en slik særskilt ordning, av en særlig og ekstraordinær årsak ikke oppfyller vilkårene for å dra nytte av den.

18) Reglene som gir adgang til en rekke former for industri-, forretnings- og håndverksvirksomhet, bør forenkles $\mathrm{i}$ medlemsstater der disse yrkene er lovregulert, forutsatt at denne virksomheten har vært utøvd $\mathrm{i}$ en annen medlemsstat $\mathrm{i}$ en tilstrekkelig lang og nylig periode, samtidig som en ordning for automatisk godkjenning basert på yrkeserfaring beholdes for disse formene for virksomhet.

19) Fri bevegelighet for og gjensidig godkjenning av kvalifikasjonsbeviser for leger, sykepleiere med ansvar for alminnelig sykepleie, tannleger, veterinærer, jordmødre, farmasøyter og arkitekter bør være basert på det grunnleggende prinsippet om automatisk godkjenning av kvalifikasjonsbeviser på grunnlag av samordnede minstekrav til utdanning. I tillegg bør adgang i medlemsstatene til yrkene som lege, sykepleier med ansvar for alminnelig sykepleie, tannlege, veterinær, jordmor og farmasøyt gjøres betinget av at utøveren innehar en særlig kvalifikasjon som sikrer at vedkommende har gjennomgått en utdanning som oppfyller de fastsatte minstekravene. Denne ordningen bør suppleres med en rekke ervervede rettigheter som kvalifiserte yrkesutøvere kan dra fordel av på visse vilkår.

20) Forå tahensyntil særtrekkeneved kvalifikasjonsordningen for leger og tannleger og gjeldende fellesskapsrett på området gjensidig godkjenning, bør prinsippet om automatisk godkjenning av spesialistkompetanse for leger og tannleger som er felles for minst to medlemsstater, fortsatt gjelde for all spesialistkompetanse som er godkjent på det tidspunkt dette direktiv trer i kraft. For å forenkle ordningen bør imidlertid automatisk godkjenning etter tidspunktet for ikrafttredelse av dette direktiv bare gjelde for de nye områdene for spesialistkompetanse som er felles for minst to femdeler av medlemsstatene. Videre er dette direktiv ikke til hinder for at medlemsstatene i samsvar med egne regler gjør gjensidig avtale om automatisk godkjenning innenfor visse områder for spesialistkompetanse for leger og tannleger som medlemsstatene har felles, men som ikke automatisk blir godkjent $\mathrm{i}$ henhold til dette direktiv.

21) Automatisk godkjenning av kvalifikasjonsbeviser for leger med grunnutdanning bør ikke berøre medlemsstatenes kompetanse til å knytte disse kvalifikasjonene til yrkesvirksomhet eller ikke. 
22) Alle medlemsstater bør godkjenne tannlegeyrket som et særskilt yrke som skiller seg fra legeyrket, uavhengig av om det foreligger spesialisering i odontostomatologi. Medlemsstatene bør sørge for at tannlegeutdanningen gir de ferdigheter som er nødvendige for forebygging, diagnostikk og behandling av misdannelser og sykdommer i tenner, munn, kjever og omkringliggende vev. Yrkesvirksomheten som tannlege bør utføres av innehavere av et kvalifikasjonsbevis som tannlege, slik det er fastsatt i dette direktiv.

23) Det syntes ikke ønskelig å fastsette standardisert utdanning for jordmødre for samtlige medlemsstater. Medlemsstatene bør isteden ha størst mulig frihet til å organisere denne utdanningen.

24) Med henblikk på å forenkle dette direktiv bør begrepet «farmasøyt» anvendes for å avgrense virkeområdet for bestemmelsene om automatisk godkjenning av kvalifikasjonsbeviser, uten at dette berører de særlige bestemmelsene i nasjonal lovgivning om denne virksomheten.

25) Innehavere av kvalifikasjonsbevis som farmasøyt er spesialister på legemidler og bør i prinsippet ha adgang til et minsteområde av virksomhet på dette området i samtlige medlemsstater. Når dette minsteområdet skal defineres, bør dette direktiv verken medvirke til å begrense den virksomhet som er tilgjengelig for farmasøyter i medlemsstatene, særlig med hensyn til biomedisinske analyser, eller opprette et monopol for disse yrkesutøverne, ettersom dette bare henhører til medlemsstatenes myndighetsområde. Bestemmelsene $i$ dette direktiv berører ikke medlemsstatenes mulighet til å innføre ytterligere utdanningsvilkår for adgang til virksomhet som ikke omfattes av det samordnede minsteområdet av virksomhet. Dette betyr at vertsstater bør kunne innføre slike vilkår for de av medlemsstatens borgere som innehar kvalifikasjoner som omfattes av automatisk godkjenning i henhold til dette direktiv.

26) Dette direktiv har ikke til hensikt å samordne alle vilkår for adgang til og utøvelse av virksomhet på området farmasi. Særlig bør den geografiske fordelingen av apoteker og monopol for utlevering av legemidler fortsatt være en sak for medlemsstatene. Dette direktiv endrer ikke lover eller forskrifter i medlemsstatene som forbyr selskaper å utøve visse former for farmasøytisk virksomhet eller som underlegger utøvelsen av slik virksomhet særlige vilkår.
27) Arkitektonisk utforming, bygningers kvalitet, deres harmoniske innpassing $\mathrm{i}$ omgivelsene, respekt for det naturlige og bymessige miljø samt den felles og private kulturarv er av offentlig interesse. Gjensidig godkjenning av kvalifikasjoner bør derfor være basert på kvalitative og kvantitative kriterier som sikrer at innehavere av godkjente kvalifikasjoner er i stand til å forstå og omsette enkeltpersoners, samfunnsgruppers og myndigheters behov med hensyn til arealplanlegging, utforming, prosjektering og oppføring av bygninger, bevaring og utnyttelse av den arkitektoniske kulturarven samt vern av den naturlige likevekt.

28) Nasjonale regler på området arkitektur og for adgang til og utøvelse av en arkitekts yrkesvirksomhet kan variere mye i omfang. I de fleste medlemsstater utøves arkitektvirksomhet rettslig eller faktisk av personer med tittelen arkitekt, enten alene eller sammen med en annen tittel, uten at disse personer dermed har enerett til utøvelsen av denne virksomheten, med mindre noe annet er bestemt ved lov. Denne virksomheten eller deler av den kan også utøves av andre yrkesgrupper, særlig ingeniører som har fått spesialutdanning innenfor bygningsfag eller byggekunst. Med henblikk på å forenkle dette direktiv bør begrepet «arkitekt» anvendes for å avgrense virkeområdet for bestemmelsene om automatisk godkjenning av kvalifikasjonene på området arkitektur, uten at det berører særlige bestemmelser i nasjonal lovgivning som styrer denne virksomheten.

29) Der en yrkessammenslutning eller -organisasjon på nasjonalt og europeisk plan for et lovregulert yrke fremmer en begrunnet anmodning om særskilte bestemmelser om godkjenning av kvalifikasjoner på grunnlag av samordning av minstekrav til utdanning, bør Kommisjonen vurdere om det er hensiktsmessig å vedta et forslag til endring av dette direktiv.

30) For å sikre at ordningen for godkjenning av yrkeskvalifikasjoner er effektiv, bør det fastsettes ensartede formaliteter og saksbehandlingsregler for gjennomføringen av den samt visse nærmere bestemmelser om utøvelsen av yrket.

31) Siden samarbeid mellom medlemsstatene og mellom medlemsstatene og Kommisjonen sannsynligvis vil lette gjennomføringen av dette direktiv og oppfyllelsen av de forpliktelsene som følger av direktivet, bør det fastsettes nærmere bestemmelser om dette samarbeidet. 
32) Innføringen på fellesskapsplan av yrkesbeviser fra yrkessammenslutninger og -organisasjoner vil kunne lette mobiliteten for fagfolk, særlig ved å gjøre utvekslingen av opplysninger mellom vertsstaten og hjemstaten raskere. Dette yrkesbeviset bør gjøre det mulig å overvåke yrkeskarrieren til fagfolk som etablerer seg i ulike medlemsstater. Slike yrkesbeviser kan, samtidig som bestemmelsene om vern av personopplysninger etterkommes, inneholde opplysninger om fagpersonens yrkeskvalifikasjoner (universitet eller utdanningsinstitusjon, tilegnede kvalifikasjoner, yrkeserfaring), vedkommendes juridiske etablering, pålagte straffetiltak i forbindelse med yrket samt opplysninger om vedkommende myndighet.

33) Etableringen av et nett av kontaktpunkter som har som oppgave å gi borgerne i medlemsstatene opplysninger og bistand, vil gjøre det mulig å sikre innsynsmulighet i ordningen for godkjenning. Disse kontaktpunktene vil gi alle borgere som anmoder om det og Kommisjonen alle opplysninger og adresser som er relevante for framgangsmåten for godkjenning. Utpeking av ett enkelt kontaktpunkt av hver enkelt medlemsstat innenfor dette nettet påvirker ikke organiseringen av kompetanse på nasjonalt plan. Dette forhindrer blant annet ikke at det på nasjonalt plan utpekes flere kontorer, der det utpekte kontaktpunktet innenfor det nevnte nettet har ansvar for samordningen med de andre kontorene og om nødvendig for å informere borgerne om det berørte vedkommende kontor.

34) Administrering av de ulike ordningene for godkjenning som opprettes av sektordirektivene og den generelle ordningen har vist seg å være tungvint og komplisert. Det er derfor behov for å forenkle administrasjonen og ajourføre dette direktiv for å ta hensyn til den vitenskapelige og tekniske utvikling, der særlig minstekravene til utdanning samordnes med henblikk på automatisk godkjenning av kvalifikasjonsbeviser. For dette formål bør det nedsettes en enkelt komité for godkjenning av yrkeskvalifikasjoner, og det bør sikres at representanter for yrkesorganisasjoner, også på europeisk plan, involveres i passende grad.

35) De tiltak som er nødvendige for gjennomføringen av dette direktiv, bør vedtas i samsvar med rådsbeslutning 1999/468/EF av 28. juni 1999 om fastsettelse av nærmere regler for utøvelsen av den gjennomføringsmyndighet som er tillagt Kommisjonen( $\left.{ }^{1}\right)$.

36) Medlemsstatenes utarbeidelse av en periodisk rapport om gjennomføringen av dette direktiv, som inneholder statistiske opplysninger, vil gjøre det mulig

(') EFT L 184 av 17.7.1999, s. 23. å fastslå virkningen av ordningen for godkjenning av yrkeskvalifikasjoner.

37) Det bør fastsettes en egnet framgangsmåte for å vedta midlertidige tiltak dersom anvendelsen av en bestemmelse i dette direktiv skulle innebære større vanskeligheter i en medlemsstat.

38) Bestemmelsene i dette direktiv berører ikke medlemsstatenes myndighet når det gjelder organiseringen av deres nasjonale trygdeordninger og fastsettelsen av den virksomhet som må utøves innenfor disse ordningene.

39) I lys av den raske teknologiske og vitenskapelige utviklingen er livslang læring av særlig betydning for et stort antall yrker. I denne sammenheng er det opp til medlemsstatene å vedta nærmere regler for hvordan fagfolk gjennom egnet videreutdanning kan holde seg à jour med den tekniske og vitenskapelige utvikling.

40) Ettersom målene for dette direktiv, som er å rasjonalisere, forenkle og forbedre reglene for godkjenning av yrkeskvalifikasjoner, ikke i tilstrekkelig grad kan nås av medlemsstatene, og derfor bedre kan nås på fellesskapsplan, kan Fellesskapet treffe tiltak i samsvar med nærhetsprinsippet som fastsatt i traktatens artikkel 5. I samsvar med forholdsmessighetsprinsippet fastsatt $i$ nevnte artikkel går dette direktiv ikke lenger enn det som er nødvendig for å nå disse målene.

41) Dette direktiv berører ikke anvendelsen av traktatens artikkel 39 nr. 4 og artikkel 45 som blant annet omhandler notarius publicus.

42) Når det gjelder etableringsrett og tjenesteyting, berører dette direktiv ikke andre særlige lovbestemmelser om godkjenning av yrkeskvalifikasjoner, for eksempel gjeldende bestemmelser på transportområdet, for forsikringsformidlere og for revisorer som foretar lovfestet revisjon. Dette direktiv berører ikke anvendelsen av rådsdirektiv 77/249/EØF av 22. mars 1977 med henblikk på å lette den faktiske gjennomføring av advokaters adgang til å yte tjenester $\left({ }^{2}\right)$, eller av europaparlaments- og rådsdirektiv 98/5/EF av 16. februar 1998 om lettelse av adgangen til å utøve advokatyrket på permanent grunnlag $i$ en annen medlemsstat enn staten der den faglige kvalifikasjonen er ervervet $\left({ }^{3}\right)$. Godkjenning av advokaters yrkeskvalifikasjoner for umiddelbar etablering under denne yrkestittel i vertsstaten bør omfattes av dette direktiv.

( $\left.{ }^{2}\right)$ EFT L 78 av 26.3.1977, s. 17. Direktivet sist endret ved tiltredelsesakten av 2003.

$\left({ }^{3}\right)$ EFT L 77 av 14.3.1998, s. 36. Direktivet sist endret ved tiltredelsesakten av 2003. 
43) I den utstrekning de er lovregulerte, omfatter dette direktiv også frie yrker, som i henhold til dette direktiv er yrker som utøves på grunnlag av relevante yrkeskvalifikasjoner, personlig, ansvarlig og yrkesmessig selvstendig, av personer som yter intellektuelle og konseptuelle tjenester i oppdragsgiverens og allmennhetens interesse. Utøvelsen av yrket kan i medlemsstatene, i samsvar med traktaten, være underlagt særlige rettslige begrensninger basert på nasjonal lovgivning og på lovbestemmelser fastsatt på en selvstendig måte, innenfor den rammen, av det representative yrkesorgan som sikrer og videreutvikler profesjonaliteten og tjenestekvaliteten og tillitsforholdet til oppdragsgiveren.

44) Dette direktiv berører ikke tiltak som er nødvendige for å sikre et høyt nivå for helse- og forbrukervern -

\section{VEDTATT DETTE DIREKTIV:}

\section{AVDELING I}

\section{ALMINNELIGE BESTEMMELSER}

\author{
Artikkel 1
}

\section{Formål}

Ved dette direktiv fastsettes reglene som en medlemsstat som krever bestemte yrkeskvalifikasjoner for adgang til eller utøvelse av et lovregulert yrke på sitt territorium (heretter kalt «vertsstaten»), skal anvende ved godkjenning av slike yrkeskvalifikasjoner for adgang til og utøvelse av yrket som er oppnådd i en eller flere andre medlemsstater (heretter kalt «hjemstaten»), og som gir innehaveren av disse kvalifikasjonene rett til å utøve yrket der.

\section{Artikkel 2}

\section{Virkeområde}

1. Dette direktiv får anvendelse på alle statsborgere i en medlemsstat som ønsker å utøve et lovregulert yrke, herunder frie yrker, i en annen medlemsstat enn der de tilegnet seg sine yrkeskvalifikasjoner, enten som selvstendig næringsdrivende eller som lønnsmottaker.

2. Alle medlemsstater kan i samsvar med egen lovgivning tillate statsborgere av andre medlemsstater som innehar kvalifikasjonsbeviser som ikke er ervervet i en medlemsstat, å utøve et lovregulert yrke i betydningen i artikkel 3 nr. 1 bokstav a) på sitt territorium. Når det gjelder yrker som omfattes av avdeling III kapittel III, skal denne første godkjenningen skje i samsvar med de minstekrav til utdanning som er fastsatt i nevnte kapittel.
3. Der det for et gitt lovregulert yrke finnes andre særlige bestemmelser direkte knyttet til godkjenning av yrkeskvalifikasjoner i et særskilt dokument i fellesskapsretten, får tilsvarende bestemmelser i dette direktiv ikke anvendelse.

Artikkel 3

\section{Definisjoner}

1. I dette direktiv menes med:

a) «lovregulert yrke» en eller flere former for yrkesvirksomhet, der adgang til og utøvelse eller en form for utøvelse direkte eller indirekte ved lov eller forskrift, er omfattet av et krav om besittelse av bestemte yrkeskvalifikasjoner; særlig skal bruken av en yrkestittel som ved lov eller forskrift er begrenset til innehavere av en gitt yrkeskvalifikasjon, utgjøre en form for utøvelse. I tilfeller der første punktum i denne definisjonen ikke får anvendelse, skal et yrke som omhandlet i nr. 2 behandles som et lovregulert yrke,

b) «yrkeskvalifikasjoner» kvalifikasjoner bekreftet ved et kvalifikasjonsbevis, en kompetanseattest som nevnt i artikkel 11 bokstav a) i) og/eller yrkeserfaring,

c) «kvalifikasjonsbevis» diplomer, attester og annen dokumentasjon utstedt av en myndighet $i$ en medlemsstat utpekt $\mathrm{i}$ henhold til lov eller forskrift i vedkommende medlemsstat og som dokumenterer en bestått yrkesrettet opplæring som i hovedsak er ervervet i Fellesskapet. I tilfeller der første punktum i denne definisjonen ikke får anvendelse, skal et kvalifikasjonsbevis som nevnt i nr. 3, behandles som et kvalifikasjonsbevis,

d) «vedkommende myndighet» enhver myndighet eller ethvert organ som er særlig bemyndiget av en medlemsstat til å utstede eller motta kvalifikasjonsbeviser og andre dokumenter eller opplysninger og til å motta søknader og treffe de beslutninger som er nevnt i dette direktiv,

e) «lovregulert utdanning» enhver utdanning som er særlig rettet mot utøvelsen av et bestemt yrke og som omfatter ett eller flere kurs, eventuelt supplert med yrkesrettet opplæring eller med en praktisk prøveperiode eller yrkespraksis.

Strukturen i og nivået på den yrkesrettede opplæringen, den praktiske prøveperioden eller yrkespraksisen skal fastsettes ved lov eller forskrift av vedkommende medlemsstat eller overvåkes eller godkjennes av den myndighet som er utpekt for dette formål, 
f) «yrkeserfaring» faktisk og lovlig utøvelse av det berørte yrket $i$ en medlemsstat,

g) «prøveperiode» utøvelse av et lovregulert yrke i vertsstaten under tilsyn av en kvalifisert utøver av dette yrket og eventuelt ledsaget av videreutdanning. Perioden med praksis under tilsyn skal være gjenstand for en vurdering. De nærmere reglene for prøveperioden og vurderingen av denne, samt status for en vandrearbeider under tilsyn, skal fastsettes av vedkommende myndighet i vertsstaten.

Den status en person har i vertsstaten i perioden med praksis under tilsyn, særlig med hensyn til oppholdsrett samt forpliktelser, sosiale rettigheter og ytelser, stønader og vederlag, skal fastsettes av vedkommende myndigheter i nevnte medlemsstat i samsvar med gjeldende fellesskapsrett,

h) «egnethetsprøve» en prøve avgrenset til søkerens faglige kunnskaper som gjennomføres av vedkommende myndigheter i vertsstaten med sikte på å vurdere søkerens evne til å utøve et lovregulert yrke i denne medlemsstaten. For at denne prøven skal kunne gjennomføres, skal vedkommende myndigheter utarbeide en liste over de fag som på grunnlag av en sammenligning mellom den utdanningen som kreves i medlemsstaten og den søkeren har, ikke dekkes av det diplom eller andre kvalifikasjonsbeviser søkeren er i besittelse av.

Egnethetsprøven skal ta hensyn til at søkeren er en kvalifisert yrkesutøver i hjemstaten eller den seneste oppholdsstaten. Prøven skal omfatte fag som velges fra listen, og som det er en vesentlig forutsetning å ha kunnskap om for å kunne utøve yrket i vertsstaten. Prøven kan også omfatte kunnskap om de yrkesetiske regler som gjelder for den berørte virksomheten i vertsstaten.

Vedkommende myndigheter i vertsstaten skal fastsette detaljerte regler for anvendelse av egnethetsprøven og hvilken status en søker som ønsker å forberede seg til egnethetsprøven, skal ha i vertsstaten,

i) «foretaksleder» enhver person som $i$ et foretak innenfor den berørte bransjen har utøvd virksomhet

i) som foretaksleder eller leder av en filial av et foretak, eller

ii) som stedfortreder for eieren av et foretak eller en foretaksleder, der stillingen innebærer et ansvar som tilsvarer eierens eller lederens ansvar, eller

iii) $\mathrm{i}$ en lederstilling med oppgaver av forretningsmessig og/eller teknisk art samt ansvar for én eller flere av foretakets avdelinger.
2. Et yrke som utøves av medlemmene av en yrkessammenslutning eller -organisasjon på listen i vedlegg I, skal behandles som et lovregulert yrke.

Formålet med yrkessammenslutningene eller -organisasjonene nevnt i første ledd er særlig å fremme og opprettholde en høy standard innenfor det berørte yrkesområdet. For dette formål er disse godkjent i en særlig form av en medlemsstat, og tildeler kvalifikasjonsbeviser til sine medlemmer, sikrer at medlemmene respekterer de reglene for yrkesutøvelse de fastsetter, og gir dem retten til å bruke en tittel eller en forkortelse eller å dra fordel av en status som tilsvarer slike formelle kvalifikasjoner.

Hver gang en medlemsstat godkjenner en yrkessammenslutning eller -organisasjon som nevnt i første ledd, skal den underrette Kommisjonen, som skal offentliggjøre en hensiktsmessig melding om dette i Den europeiske unions tidende.

3. Et kvalifikasjonsbevis utstedt av en tredjestat skal anses som et kvalifikasjonsbevis dersom innehaveren har tre års yrkeserfaring $\mathrm{i}$ det berørte yrket på territoriet til den medlemsstat som godkjente kvalifikasjonsbeviset i samsvar med artikkel 2 nr. 2 som er godkjent av denne medlemsstaten.

\section{Artikkel 4}

\section{Virkninger av godkjenningen}

1. Vertsstatens godkjenning av yrkeskvalifikasjoner tillater at den begunstigede $\mathrm{i}$ den berørte medlemsstaten făr adgang til det samme yrket som vedkommende er kvalifisert til i hjemstaten og til å utøve det $\mathrm{i}$ vertsstaten på samme vilkår som medlemsstatens borgere.

2. I dette direktiv er det yrket som søkeren ønsker å utøve i vertsstaten det samme som søkeren er kvalifisert for i sin hjemstat, dersom de former for virksomhet yrket omfatter er sammenlignbare.

\section{AVDELING II}

\section{FRI TJENESTEYTING}

Artikkel 5

\section{Prinsippet om fri tjenesteyting}

1. Uten at det berører de særlige bestemmelsene i fellesskapsretten og artikkel 6 og 7 i dette direktiv, skal ikke medlemsstatene av noen grunn knyttet til yrkeskvalifikasjoner, begrense fri tjenesteyting i en annen medlemsstat,

a) dersom tjenesteyteren er lovlig etablert $i$ en medlemsstat med det formål å utøve det samme yrket der (heretter kalt «etableringsstaten»), og 
b) dersom tjenesteyteren flytter, og dersom vedkommende har utøvd yrket i etableringsstaten i minst to år i løpet av de siste ti år før tjenesteytingen og yrket ikke er lovregulert $\mathrm{i}$ denne medlemsstaten. Vilkåret om to års utøvelse får ikke anvendelse når enten yrket eller utdanningen til yrket er lovregulert.

2. Bestemmelsene i denne avdeling får anvendelse bare der tjenesteyteren flytter til vertsstatens territorium for midlertidig og leilighetsvis å utøve yrket nevnt i nr. 1 .

Tjenesteytingens midlertidige og leilighetsvise art skal vurderes fra sak til sak, særlig på grunnlag av ytingens varighet, hyppighet, regelmessighet og kontinuitet.

3. En tjenesteyter som flytter, skal være underlagt de faglige, lovgivningsmessige eller administrative reglene som gjelder yrket som er direkte knyttet til yrkeskvalifikasjoner, som for eksempel definisjonen av yrket, bruken av titler og alvorlig yrkesmessig forsømmelse som er direkte og særlig knyttet til forbrukervern og sikkerhet, samt disiplinærbestemmelser som får anvendelse i vertsstaten overfor fagfolk som utøver det samme yrket i denne medlemsstaten.

Artikkel 6

\section{Unntak}

I henhold til artikkel 5 nr. 1 skal vertsstaten unnta tjenesteytere som er etablert $\mathrm{i}$ en annen medlemsstat fra de krav den pålegger fagfolk etablert på vertsstatens territorium knyttet til

a) godkjenning av, registrering $i$ eller medlemskap i en yrkesorganisasjon eller et yrkesorgan. For å lette anvendelsen av de gjeldende disiplinærbestemmelsene på medlemsstatenes territorium i samsvar med artikkel 5 nr. 3, kan medlemsstatene enten fastsette en automatisk midlertidig registrering eller et proforma medlemskap i en slik yrkesorganisasjon eller et slikt yrkesorgan, forutsatt at denne registreringen eller dette medlemskapet ikke på noen måte forsinker eller kompliserer tjenesteytingen og ikke medfører tilleggskostnader for tjenesteyteren. En kopi av erklæringen og eventuelt av fornyelsen nevnt $\mathrm{i}$ artikkel $7 \mathrm{nr}$. 1, ledsaget av, for yrker som har sammenheng med offentlig helse og sikkerhet nevnt i artikkel 7 nr. 4 eller som drar fordel av automatisk godkjenning i henhold til avdeling III kapittel III, en kopi av dokumentene nevnt i artikkel $7 \mathrm{nr}$. 2, skal oversendes av vedkommende myndighet til vedkommende yrkesorganisasjon eller -organ, og skal for dette formål utgjøre automatisk midlertidig registrering eller proforma medlemskap,

b) registrering $\mathrm{i}$ et offentlig trygdeorgan med det formål å foreta avregninger med en forsikringsgiver for virksomhet som utøves til fordel for forsikrede personer.

Tjenesteyteren skal imidlertid på forhånd eller, dersom det haster, i etterkant underrette organet nevnt i bokstav b) om de tjenester vedkommende har ytt.

Artikkel 7

\section{Erklæring som skal avgis på forhånd dersom tjenesteyteren flytter}

1. Medlemsstatene kan kreve at en tjenesteyter som for første gang flytter fra én medlemsstat til en annen for å yte tjenester, på forhånd skal underrette vedkommende myndighet $\mathrm{i}$ vertsstaten om dette $\mathrm{i}$ form av en skriftlig erklæring, som omfatter nærmere opplysninger om en eventuell forsikringsdekning eller andre former for personlig eller kollektiv beskyttelse med hensyn til yrkesansvar. En slik erklæring skal fornyes hvert år dersom tjenesteyteren har til hensikt å yte midlertidige eller leilighetsvise tjenester i denne medlemsstaten i løpet av året. Tjenesteyteren kan selv velge hvordan denne erklæringen meddeles.

2. Ved første gangs tjenesteyting eller ved en vesentlig endring av de forhold som omhandles av dokumentene, kan medlemsstatene dessuten kreve at erklæringen ledsages av følgende dokumenter:

a) Bevis på tjenesteyterens nasjonalitet.

b) En bekrefteattest som bekrefter at innehaveren er lovlig etablert $\mathrm{i}$ en medlemsstat med det formål å utøve den berørte virksomheten, og at vedkommende på tidspunktet for utstedelse av attesten ikke er pålagt noe forbud, heller ikke midlertidig, mot å utøve denne virksomheten.

c) Bevis på yrkeskvalifikasjoner.

d) For tilfeller nevnt i artikkel $5 \mathrm{nr}$. 1 bokstav b), alle former for dokumentasjon på at tjenesteyteren har utøvd den berørte virksomheten $\mathrm{i}$ minst to år i løpet av de siste ti årene.

e) For yrker innenfor sikkerhetsbransjen, der medlemsstaten krever dette for egne borgere, bevis for at tjenesteyteren ikke er dømt for noe straffbart forhold. 
3. Tjenesten skal ytes under yrkestittelen i etableringsstaten, i den grad en slik tittel eksisterer i denne medlemsstaten for den berørte yrkesvirksomheten. Denne tittelen skal angis på det offisielle språket eller på ett av de offisielle språkene i etableringsstaten på en slik måte at det unngås forveksling med yrkestittelen i vertsstaten. Dersom yrkestittelen ikke finnes i etableringsstaten, skal tjenesteyteren angi sine formelle kvalifikasjoner på det offisielle språket eller ett av de offisielle språkene i vedkommende medlemsstat. Unntaksvis kan tjenesten ytes under yrkestittelen i bruk i vertsstaten når det gjelder tilfeller nevnt i avdeling III kapittel III.

4. For førstegangs tjenesteyting når det gjelder lovregulerte yrker som har sammenheng med offentlig helse eller sikkerhet og som ikke omfattes av automatisk godkjenning i henhold til avdeling III kapittel III, kan vedkommende myndighet $i$ vertsstaten kontrollere yrkeskvalifikasjonene til tjenesteyteren før tjenestene ytes for første gang. En slik forhåndskontroll skal være mulig bare dersom formålet med kontrollen er å unnga alvorlig skade for tjenestemottakerens helse eller sikkerhet på grunn av manglende yrkeskvalifikasjoner fra tjenesteyterens side, og der dette ikke går ut over det som er nødvendig for dette formål.

Innen høyst én måned etter å ha mottatt erklæringen og ledsagende dokumenter skal vedkommende myndighet bestrebe seg på å underrette tjenesteyteren om sin beslutning om ikke å kontrollere tjenesteyterens kvalifikasjoner eller om resultatet av en slik kontroll. Dersom det oppstår problemer som fører til forsinkelse, skal vedkommende myndighet underrette tjenesteyteren senest innen én måned om grunnen til forsinkelsen og tidsplanen for en beslutning, som må være fattet senest to måneder etter at fullstendig dokumentasjon er mottatt.

Dersom det er en vesentlig forskjell mellom yrkeskvalifikasjonene til tjenesteyteren og den utdanningen som kreves i vertsstaten, og i den utstrekning denne forskjellen er slik at den kan være skadelig for offentlig helse eller sikkerhet, skal vertsstaten gi tjenesteyteren mulighet til å vise, særlig ved hjelp av en egnethetsprøve, at vedkommende har skaffet seg den manglende kunnskapen eller kompetansen. I alle tilfeller skal tjenesten kunne ytes innen én måned etter at en beslutning er truffet i samsvar med forrige ledd.

Dersom vedkommende myndighet ikke har svart innen fristene i de foregående ledd, kan tjenesten ytes.

I tilfeller der kvalifikasjoner er blitt bekreftet i henhold til dette nummer, skal tjenesten kunne ytes under den yrkestittelen som brukes i vertsstaten.
Artikkel 8

\section{Administrativt samarbeid}

1. Vedkommende myndigheter i vertsstaten kan, for hvert tilfelle av tjenesteyting, be vedkommende myndigheter $\mathrm{i}$ etableringsstaten om alle opplysninger om hvorvidt tjenesteyteren er lovlig etablert, om vedkommendes redelige atferd samt om at vedkommende ikke har vært ilagt disiplinære eller straffesrettslige sanksjoner av yrkesmessig art. Vedkommende myndigheter i etableringsstaten skal gi disse opplysningene i samsvar med bestemmelsene i artikkel 56.

2. Vedkommende myndigheter skal sikre utveksling av alle opplysninger som er nødvendige for at klager fra en mottaker av en tjeneste mot en tjenesteyter skal bli fulgt opp på riktig måte. Mottakere skal underrettes om resultatet av klagen.

Artikkel 9

\section{Opplysninger til tjenestemottakerne}

I tilfeller der tjenesten ytes i henhold til etableringsstatens yrkestittel eller i henhold til tjenesteyterens kvalifikasjonsbevis, kan vedkommende myndigheter i vertsstaten kreve at tjenesteyteren, i tillegg til de andre opplysningkravene som er fastsatt i fellesskapsretten, gir tjenestemottakeren noen av eller alle opplysningene nedenfor:

a) Dersom tjenesteyteren er registrert $i$ et handelsregister eller et lignende offentlig register, det registeret der tjenesteyteren er registrert samt vedkommendes registreringsnummer, eller en tilsvarende måte å identifisere opplysninger på i dette registeret.

b) Dersom virksomheten er omfattet av en tillatelsesordning $\mathrm{i}$ etableringsstaten, navnet på og adressen til vedkommende tilsynsmyndighet.

c) Eventuell yrkessammenslutning eller lignende organ som tjenesteyteren er registrert $i$.

d) Tjenesteyterens yrkestittel, eller dersom en slik tittel ikke finnes, bevis på tjenesteyterens formelle kvalifikasjoner samt medlemsstaten der det ble tildelt.

e) Dersom tjenesteyteren utøver virksomhet som er underlagt merverdiavgift (mva.), registreringsnummeret for merverdiavgift som nevnt $\mathrm{i}$ artikkel $22 \mathrm{nr}$. $1 \mathrm{i}$ sjette rådsdirektiv 77/388/EØF av 17. mai 1977 om harmonisering av medlemsstatenes lovgivning med hensyn til omsetningsavgift — Felles merverdiavgiftssystem: ensartet avgiftsgrunnlag $\left({ }^{1}\right)$.

f) Nærmere opplysninger om eventuell forsikringsdekning eller andre former for personlig eller kollektiv beskyttelse med hensyn til yrkesansvar.

(1) EFT L 145 av 13.6.1977, s. 1. Direktivet sist endret ved direktiv 2004/66/ EF (EUT L 168 av 1.5.2004, s. 35). 
AVDELING III

\section{ETABLERINGSADGANG}

\author{
KAPITTEL I
}

Generell ordning for godkjenning av kvalifikasjonsbeviser

Artikkel 10

\section{Virkeområde}

Dette kapittel får anvendelse på alle yrker som ikke omfattes av kapittel II og III i denne avdeling, og i følgende tilfeller der søkeren av særlige og unntaksvise årsaker ikke oppfyller vilkårene fastsatt i de nevnte kapitlene:

a) For virksomhet oppført i vedlegg IV når vandrearbeideren ikke oppfyller kravene i artikkel 17, 18 og 19.

b) For leger med grunnutdanning, leger med spesialistutdanning, sykepleiere med ansvar for alminnelig sykepleie, tannleger, spesialistutdannede tannleger, veterinærer, jordmødre, farmasøyter og arkitekter når vandrearbeideren ikke oppfyller kravene til faktisk og lovlig yrkespraksis som omhandlet i artikkel 23, 27, 33, 37, 39,43 og 49 .

c) For arkitekter når vandrearbeideren innehar et kvalifikasjonsbevis som ikke er oppført i vedlegg V nr. 5.7.

d) Uten at det berører artikkel $21 \mathrm{nr}$. 1, artikkel 23 og artikkel 27, for leger, sykepleiere, tannleger, veterinærer, jordmødre, farmasøyter og arkitekter som har kvalifikasjonsbeviser som spesialist, som må ha deltatt $\mathrm{i}$ den utdanningen som fører til at de oppnår en tittel oppført i nr. 5.1.1, 5.2.2, 5.3.2, 5.4.2, 5.5.2, 5.6.2 og 5.7.1 i vedlegg V, og bare for godkjenning av relevant spesialfelt.

e) For sykepleiere med ansvar for alminnelig sykepleie og spesialsykepleiere som har kvalifikasjonsbevis som spesialist, som har deltatt i utdanningen som fører til at de oppnår en tittel oppført på listen i vedlegg V nr. 5.2.2, når vandrearbeideren søker godkjenning $\mathrm{i}$ en annen medlemsstat der den relevante yrkesvirksomheten utøves av spesialsykepleiere uten utdanning som sykepleier med ansvar for alminnelig sykepleie.

f) For spesialsykepleiere uten utdanning som sykepleier med ansvar for alminnelig sykepleie, når vandrearbeideren søker godkjenning $\mathrm{i}$ en annen medlemsstat der den relevante yrkesvirksomheten utøves av sykepleiere med ansvar for alminnelig sykepleie, spesialsykepleiere uten utdanning som sykepleier med ansvar for alminnelig sykepleie eller spesialsykepleiere som har kvalifikasjonsbevis som spesialist, som har deltatt $\mathrm{i}$ utdanningen som fører til at de oppnår en av titlene oppført på listen i nr. 5.2.2 i vedlegg V. g) For vandrearbeidere som oppfyller kravene i artikkel 3 nr. 3.

Artikkel 11

\section{Kvalifikasjonsnivåer}

For anvendelsen av artikkel 13 er yrkeskvalifikasjonene gruppert i nivåer slik det er beskrevet nedenfor:

a) En kompetanseattest utstedt av vedkommende myndighet i hjemstaten utpekt $\mathrm{i}$ henhold til lover eller forskrifter i denne medlemsstaten på grunnlag av

i) enten en utdanning som ikke utgjør en del av en attest eller et diplom i henhold til bokstav b), c), d) eller e), eller en særskilt eksamen uten forutgående utdanning, eller utøvelse av yrket på heltid i en medlemsstat $i$ tre sammenhengende år eller av tilsvarende varighet på deltid i løpet av de siste ti årene,

ii) eller allmennutdanning fra grunnskole eller videregående opplæring som viserbekrefte at innehaveren har ervervet allmenne kunnskaper.

b) En attest på en bestått videregående opplæring,

i) enten allmennutdanning supplert av et annet studium eller annen yrkesrettet opplæring enn den som er nevnt $i$ bokstav c), og/eller av en praktisk prøveperiode eller yrkespraksis som kreves i tillegg til nevnte studium,

ii) eller av teknisk eller yrkesfaglig art, eventuelt supplert med et studium eller en yrkesrettet opplæring som nevnt i punkt i), og/eller av en praktisk prøveperiode eller yrkespraksis som kreves i tillegg til nevnte studium.

c) Et diplom for

i) enten en annen utdanning ut over videregående opplæring enn den som er nevnt i bokstav d) og e), av minst ett års varighet, eller av tilsvarende varighet på deltid, der et av opptaksvilkårene vanligvis er at søkeren har bestått den videregående opplæringen som er nødvendig for å oppnå adgang til studier på universitets- eller høyskolenivå, eller fullføring av tilsvarende utdanning til videregående opplæring samt den yrkesrettede opplæringen som måtte kreves i tillegg til denne utdanningen ut over videregående opplæring, 
ii) eller når det gjelder et lovregulert yrke, opplæring med en særlig struktur, omhandlet i vedlegg II, som tilsvarer utdanningsnivået fastsatt i punkt i), som gir et sammenlignbart faglig nivå og som forbereder utøveren til et sammenlignbart nivå med hensyn til ansvar og funksjoner. Listen i vedlegg II kan endres etter framgangsmåten nevnt i artikkel $58 \mathrm{nr} .2$ for å ta hensyn til utdanning som oppfyller kravene i forrige punktum.

d) Et diplom for en bestått utdanning etter videregående opplæring av minst tre års og høyst fire års varighet, eller av tilsvarende varighet på deltid, ved et universitet eller en høyskole eller en annen utdanningsinstitusjon på tilsvarende nivå, samt den yrkesrettede opplæringen som måtte kreves i tillegg til utdanningen ut over videregående opplæring.

e) Et diplom for en bestått utdanning ut over videregående opplæring av minst fire års varighet, eller av tilsvarende varighet på deltid, ved et universitet eller en høyskole eller en annen utdanningsinstitusjon på tilsvarende nivå samt den yrkesrettede opplæringen som kreves i tillegg til utdanningen ut over videregående opplæring.

\section{Artikkel 12}

\section{Sidestilte kvalifikasjoner}

Alle kvalifikasjonsbeviser eller sett av kvalifikasjonsbeviser utstedt av vedkommende myndighet $i$ en medlemsstat for en bestått utdanning innenfor Fellesskapet, som er godkjent av vedkommende medlemsstat for å være på et tilsvarende nivå og som gir samme rett til adgang til eller utøvelse av et yrke eller forbereder til utøvelse av dette yrket, skal sidestilles med et kvalifikasjonsbevis av den typen som omfattes av artikkel 11, også det berørte nivået.

Alle yrkeskvalifikasjonsbeviser, selv om de ikke oppfyller kravene i hjemstatens gjeldende lover eller forskrifter for adgang til eller utøvelse av et yrke, som gir innehaveren rettigheter i henhold til disse bestemmelser, skal også sidestilles med slike kvalifikasjonsbeviser på de samme vilkår som i første ledd. Dette gjelder særlig dersom hjemstaten hever nivået på den utdanning som kreves for adgang til og utøvelse av et yrke, og dersom en person som har gjennomgått den tidligere utdanningen, som ikke oppfyller de nye kvalifikasjonskravene, drar fordel av ervervede rettigheter i henhold til nasjonale lover eller forskrifter. I slike tilfeller, ved anvendelsen av artikkel 13, anser vertsstaten at den tidligere utdanningen tilsvarer nivået på den nye utdanningen.
Artikkel 13

\section{Vilkår for godkjenning}

1. Dersom en vertsstat krever særlige yrkeskvalifikasjoner for adgang til eller utøvelse av et lovregulert yrke, skal vedkommende myndighet $\mathrm{i}$ denne medlemsstaten tillate adgang til og utøvelse av dette yrket på samme vilkår som gjelder for medlemsstatens borgere, for søkere som innehar den kompetanseattest eller det kvalifikasjonsbevis som kreves av en annen medlemsstat for adgang til eller utøvelse av yrket på dennes territorium.

Kompetanseattester eller kvalifikasjonsbeviser skal oppfylle følgende vilkår:

a) De skal være utstedt av en vedkommende myndighet i en medlemsstat, utpekt i samsvar med denne medlemsstatens lover eller forskrifter.

b) De skal bekrefte et nivå for yrkeskvalifikasjoner som minst tilsvarer nivået umiddelbart før det nivået som kreves i vertsstaten, slik det er beskrevet i artikkel 11.

2. Adgang til og utøvelse av yrket, slik det er beskrevet i nr. 1, skal også gis søkere som har utøvd yrket omhandlet i nevnte nummer på heltid i to år i løpet av de foregående ti årene i en annen medlemsstat som ikke lovregulerer dette yrket, forutsatt at de innehar en eller flere kompetanseattester eller en eller flere kvalifikasjonsbeviser.

Kompetanseattester og kvalifikasjonsbeviser skal oppfylle følgende vilkår:

a) De skal være utstedt av en vedkommende myndighet $i$ en medlemsstat, utpekt i samsvar med denne medlemsstatens lover eller forskrifter.

b) De skal bekrefte et nivå for yrkeskvalifikasjoner som minst tilsvarer nivået umiddelbart før det nivået som kreves i vertsstaten, slik det er beskrevet i artikkel 11.

c) De skal bekrefte at innehaveren er forberedt til å utøve det berørte yrket.

De to årene med yrkeserfaring som nevnt i første ledd, kan imidlertid ikke kreves dersom kvalifikasjonsbeviset som søkeren innehar, bekrefter lovregulert utdanning i henhold til artikkel 3 nr. 1 bokstav e) på de kvalifikasjonsnivåer som angis i artikkel 11 bokstav b), c), d) eller e). Den lovregulerte utdanningen oppført i vedlegg III skal anses som slik lovregulert utdanning på det nivå som er beskrevet i artikkel 11 bokstav c). Listen i vedlegg III kan endres etter framgangsmåten nevnt i artikkel 58 nr. 2 for å ta hensyn til lovregulert utdanning som gir en sammenlignbar yrkesmessig standard og som forbereder utøveren til et sammenlignbart nivå med hensyn til ansvar og funksjoner. 
3. Som unntak fra nr. 1 bokstav b) og nr. 2 bokstav b) skal vertsstaten tillate adgang til og utøvelse av et lovregulert yrke der adgang til dette yrket på vertsstatens territorium forutsetter at utøveren innehar et kvalifikasjonbevis som bekrefter en bestått utdanning på høyskole- eller universitetsnivå av minst fire års varighet, og der søkeren innehar en kvalifikasjon nevnt i artikkel 11 bokstav c).

\section{Artikkel 14}

\section{Utligningstiltak}

1. Artikkel 13 er ikke til hinder for at vertsstaten pålegger søkeren å fullføre en prøveperiode på inntil tre år eller avlegge en egnethetsprøve dersom

a) varigheten av utdanningen søkeren framlegger kvalifikasjonsbevis for i henhold til artikkel $13 \mathrm{nr}$. 1 eller 2 , er minst ett år kortere enn det som kreves i vertsstaten,

b) utdanningen som søkeren har gjennomgått, omfatter fagområder som er vesentlig forskjellige fra dem som omfattes av det kvalifikasjonsbeviset som kreves i vertsstaten,

c) det lovregulerte yrket i vertsstaten omfatter en eller flere former for lovregulert yrkesvirksomhet som ikke eksisterer i det tilsvarende yrket i søkerens hjemstat i henhold til artikkel $4 \mathrm{nr}$. 2, og at forskjellen består i særlig utdanning som kreves i vertsstaten og som omfatter fagområder som er vesentlig forskjellige fra dem som omfattes av søkerens kompetanseattest eller kvalifikasjonsbevis.

2. Dersom vertsstaten gjør bruk av muligheten i nr. 1, skal den gi søkeren valget mellom en prøveperiode og en egnethetsprøve.

Dersom en medlemsstat med hensyn til et bestemt yrke anser at det er nødvendig å fravike kravet $\mathrm{i}$ forrige ledd om at medlemsstaten skal gi søkeren valget mellom en prøveperiode og en egnethetsprøve, skal den underrette de andre medlemsstatene og Kommisjonen på forhånd og framlegge en tilstrekkelig begrunnelse for fravikelsen.

Dersom Kommisjonen, etter å ha mottatt alle nødvendige opplysninger, anser at fravikelsen nevnt $\mathrm{i}$ annet ledd ikke er hensiktsmessig eller at det ikke er i samsvar med fellesskapsretten, skal den innen tre måneder anmode vedkommende medlemsstat om å unnlate å treffe det planlagte tiltaket. I fravær av svar fra Kommisjonen innen nevnte frist kan fravikelsen anvendes.

3. Som unntak fra prinsippet i nr. 2 om søkerens rett til å velge, og for yrker der utøvelsen krever nøyaktige kunnskaper om nasjonal lovgivning og der rådgivning og/eller bistand i forbindelse med nasjonal lovgivning utgjør en vesentlig og fast del av yrkesvirksomheten, kan vertsstaten fastsette enten en prøveperiode eller en egnethetsprøve.

Dette får også anvendelse i de tilfeller som framgår av artikkel 10 bokstav b) og c), artikkel 10 bokstav d) om leger og tannleger, artikkel 10 bokstav f) når vandrearbeideren søker godkjenning i en annen medlemsstat der den berørte yrkesvirksomheten utøves av sykepleiere med ansvar for alminnelig sykepleie, eller spesialsykepleiere som har kvalifikasjonsbevis som spesialist, som har deltatt i den utdanningen som fører til at de kan benytte en tittel oppført $\mathrm{i}$ nr. 5.2.2 i vedlegg $\mathrm{V}$ og i artikkel 10 bokstav g).

I de tilfeller som omfattes av artikkel 10 bokstav a), kan vertsstaten kreve en prøveperiode eller en egnethetsprøve dersom vandrearbeideren har til hensikt å utøve yrkesvirksomhet som selvstendig næringsdrivende eller foretaksleder som krever kunnskap om og anvendelse av gjeldende nasjonale særregler, forutsatt at vedkommende myndighet $\mathrm{i}$ vertsstaten krever kunnskap om og anvendelse av disse nasjonale reglene for at medlemsstatens egne borgere skal få adgang til virksomheten.

4. Ved anvendelsen av nr. 1 bokstav b) og c) menes med «fagområder som er vesentlig forskjellige fra» fagområder der kunnskap er avgjørende for utøvelsen av yrket, og der den utdanningen vandrearbeideren har fått, viser viktige forskjeller når det gjelder varighet eller innhold i forhold til den utdanning som kreves i vertsstaten.

5. Nr. 1 får anvendelse idet det tas behørig hensyn til forholdsmessighetsprinsippet. Dersom vertsstaten har til hensikt å kreve at søkeren fullfører en prøveperiode eller avlegger en egnethetsprøve, skal den først undersøke om den kunnskapen som søkeren har ervervet ved sin yrkeserfaring $\mathrm{i}$ en medlemsstat eller i en tredjestat, er av en slik art at den helt eller delvis utligner den vesentlige forskjellen nevnt i nr. 4.

Artikkel 15

\section{Fritak for utligningstiltak på grunnlag av felles plattformer}

1. I denne artikkel mens med «felles plattformer» et sett av kriterier for yrkeskvalifikasjoner som er egnet å utligne de vesentlige forskjeller som er påvist mellom de forskjellige medlemsstatenes utdanningskrav til et bestemt yrke. Disse vesentlige forskjellene skal fastsettes ved en sammenligning av utdanningens varigheten og innhold i minst to tredeler av medlemsstatene, herunder alle medlemsstater som lovregulerer dette yrket. Forskjellene i utdanningens innhold kan være resultatet av vesentlige forskjeller i hva som omfattes av yrkesvirksomheten. 
2. Felles plattformer, slik de er definert i nr. 1, kan oversendes Kommisjonen av medlemsstatene eller av yrkessammenslutninger eller -organisasjoner som er representative på nasjonalt og europeisk plan. Dersom Kommisjonen, etter samråd med medlemsstatene, er av den oppfatning at et utkast til felles plattform vil lette den gjensidige godkjenningen av yrkeskvalifikasjoner, kan den framlegge utkast til tiltak i den hensikt å vedta disse etter framgangsmåten nevnt i artikkel 58 nr. 2.

3. Der søkerens yrkeskvalifikasjoner oppfyller kriteriene fastsatt i tiltaket vedtatt i samsvar med nr. 2, skal vertsstaten frafalle anvendelsen av utligningstiltak i henhold til artikkel 14.

4. Nr. 1-3 skal ikke påvirke medlemsstatenes myndighet til å fastsette hvilke yrkeskvalifikasjoner som kreves for utøvelse av yrker på deres territorium og innholdet $\mathrm{i}$ og organiseringen av deres ordninger for undervisning og yrkesrettet utdanning.

5. Dersom en medlemsstat anser at kriteriene fastsatt $i$ et tiltak vedtatt i samsvar med nr. 2 ikke lenger gir tilstrekkelige garantier med hensyn til yrkeskvalifikasjoner, skal den underrette Kommisjonen om dette, og Kommisjonen skal, dersom dette er hensiktsmessig, framlegge et utkast til tiltak etter framgangsmåten nevnt i artikkel 58 nr. 2.

6. Kommisjonen skal innen 20. oktober 2010 framlegge for Europaparlamentet og Rådet en rapport om anvendelsen av denne artikkel og om nødvendig egnede forslag til endring av denne artikkel.

\section{KAPITTEL II}

Artikkel 16

\section{Krav til yrkeserfaring}

Dersom adgang til eller utøvelse av en av formene for virksomhet oppført i vedlegg IV i en medlemsstat forutsetter allmenne, forretningsmessige eller yrkesfaglige kunnskaper og ferdigheter, skal denne medlemsstaten som tilstrekkelig bevis på slike kunnskaper og ferdigheter godkjenne tidligere utøvelse av den berørte virksomheten i en annen medlemsstat. Virksomheten skal ha vært utøvd i samsvar med artikkel 17, 18 og 19

Artikkel 17

\section{Virksomhet oppført på liste I i vedlegg IV}

1. Når det gjelder de former for virksomhet som er oppført på liste I i vedlegg IV, skal den berørte virksomheten tidligere ha vært utøvd

a) i seks sammenhengende år som selvstendig næringsdrivende eller foretaksleder, eller

b) i tre sammenhengende år som selvstendig næringsdrivende eller foretaksleder, dersom den begunstigede for den berørte virksomheten kan bevise å ha gjennomført en forutgående utdanning på minst tre år, bekreftet ved en attest godkjent av medlemsstaten eller vurdert som fullt ut gyldig av et vedkommende bransjeorgan, eller

c) i fire sammenhengende år som selvstendig næringsdrivende eller foretaksleder, dersom den begunstigede for den berørte virksomheten kan bevise å ha gjennomført, en forutgående utdanning på minst to år, bekreftet ved en attest godkjent av medlemsstaten eller vurdert som fullt ut gyldig av et vedkommende bransjeorgan, eller

d) i tre sammenhengende år som selvstendig næringsdrivende dersom den begunstigede kan bevise å ha utøvd den berørte virksomheten i minst fem år som lønnsmottaker, eller

e) i fem sammenhengende år i en ledende stilling, hvorav minst tre år med tekniske oppgaver og med ansvar for minst én avdeling i selskapet, dersom den begunstigede for den berørte virksomheten kan bevise å ha gjennomført en forutgående utdanning på minst tre år, bekreftet ved en attest godkjent av medlemsstaten eller vurdert som fullt ut gyldig av et vedkommende bransjeorgan.

2. I tilfellene nevnt i bokstav a) og d) kan virksomheten ikke ha vært avsluttet tidligere enn ti år før datoen da den fullstendige søknaden framlegges for vedkommende myndighet nevnt $\mathrm{i}$ artikkel 56.

3. Nr. 1 bokstav e) får ikke anvendelse på virksomhet i gruppe ex 855, frisørvirksomhet, i ISIC-nomenklaturen.

\section{Artikkel 18}

\section{Virksomhet oppført på liste II i vedlegg IV}

1. Når det gjelder de former for virksomhet som er oppført på liste I i vedlegg IV, skal den berørte virksomheten tidligere ha vært utøvd

a) i fem sammenhengende år som selvstendig næringsdrivende eller som foretaksleder, eller

b) i tre sammenhengende år som selvstendig næringsdrivende eller som foretaksleder, dersom den begunstigede for den berørte virksomheten kan bevise å ha gjennomført minst tre års forutgående utdanning, bekreftet ved en attest godkjent av medlemsstaten eller vurdert som fullt ut gyldig av et vedkommende bransjeorgan, eller 
c) i fire sammenhengende år som selvstendig næringsdrivende eller som foretaksleder, dersom den begunstigede for den berørte virksomheten kan bevise å ha gjennomført minst to års forutgående utdanning, bekreftet ved en attest godkjent av medlemsstaten eller vurdert som fullt ut gyldig av et vedkommende bransjeorgan, eller

d) i tre sammenhengende år som selvstendig næringsdrivende eller som foretaksleder, dersom den begunstigede kan bevise å ha utøvd den berørte virksomheten i minst fem år som lønnsmottaker, eller

e) i fem sammenhengende år som lønnsmottaker, dersom den begunstigede for den berørte virksomheten kan bevise å ha gjennomført minst tre års forutgående utdanning, bekreftet ved en attest godkjent av medlemsstaten eller vurdert som fullt ut gyldig av et vedkommende bransjeorgan, eller

f) i seks sammenhengende år som lønnsmottaker, dersom den begunstigede for den berørte virksomheten kan bevise å ha gjennomført minst to års forutgående utdanning, bekreftet ved en attest godkjent av medlemsstaten eller vurdert som fullt ut gyldig av et vedkommende bransjeorgan.

2. I tilfellene nevnt i bokstav a) og d) kan virksomheten ikke ha vært avsluttet tidligere enn ti år før datoen da den fullstendige søknaden framlegges for vedkommende myndighet nevnt i artikkel 56.

Artikkel 19

\section{Virksomhet oppført på liste III i vedlegg IV}

1. Når det gjelder de former for virksomhet som er oppført på liste III i vedlegg IV, skal den berørte virksomheten tidligere ha vært utøvd

a) i tre sammenhengende år som selvstendig næringsdrivende eller som foretaksleder, eller

b) i to sammenhengende år som selvstendig næringsdrivende eller som foretaksleder, dersom den begunstigede for den berørte virksomheten kan bevise å ha gjennomgått forutgående utdanning, bekreftet ved en attest godkjent av medlemsstaten eller vurdert som fullt ut gyldig av et vedkommende bransjeorgan, eller

c) i to sammenhengende år som selvstendig næringsdrivende eller som foretaksleder, dersom den begunstigede kan bevise å ha utøvd den berørte virksomheten i minst tre år som lønnsmottaker, eller

d) i tre sammenhengende år som lønnsmottaker, dersom den begunstigede for den berørte virksomheten kan bevise å ha gjennomgått forutgående utdanning, bevitnet ved en attest godkjent av medlemsstaten eller vurdert som fullt ut gyldig av et vedkommende bransjeorgan.

2. I tilfellene nevnt i bokstav a) og c) kan virksomheten ikke ha vært avsluttet tidligere enn ti år før datoen da den fullstendige søknaden framlegges for vedkommende myndighet nevnt i artikkel 56.

Artikkel 20

Endring av listene over virksomhet i vedlegg IV

Listene over virksomhet i vedlegg IV, som er gjenstand for godkjenning av yrkeserfaring i henhold til artikkel 16, kan endres etter framgangsmåten nevnt i artikkel $58 \mathrm{nr}$. 2 med det formål å ajourføre eller klargjøre nomenklaturen, forutsatt at dette ikke medfører noen endring av virksomheten i de enkelte kategoriene.

KAPITTEL III

\section{Godkjenning på grunnlag av samordning av minstekrav til utdanning}

\section{AVSNITT 1}

\section{Alminnelige bestemmelser}

\section{Artikkel 21}

\section{Prinsippet om automatisk godkjenning}

1. Allemedlemsstaterskalgodkjennedekvalifikasjonsbeviser som lege som gir adgang til yrkesvirksomhet som lege med grunnutdanning og spesialistutdanning, som sykepleier med ansvar for alminnelig sykepleie, som tannlege, som tannlege med spesialistutdanning, som veterinær, som farmasøyt og som arkitekt, slik det framgår av listen i vedlegg V, henholdsvis $\mathrm{nr}$. 5.1.1, 5.1.2, 5.2.2, 5.3.2, 5.3.3, 5.4.2, 5.6.2 og 5.7.1, som oppfyller minstevilkårene for utdanning nevnt $\mathrm{i}$ henholdsvis artikkel 24, 25, 31, 34, 35, 38, 44 og 46, og skal med hensyn til adgang til og utøvelse av yrkesvirksomhet gi slike kvalifikasjonsbeviser samme virkning på medlemsstatens territorium som de kvalifikasjonsbevisene medlemsstaten selv utsteder.

Slike kvalifikasjonsbeviser skal være utstedt av vedkommende organer i medlemsstatene, og der det er hensiktsmessig være ledsaget av attestene $\mathrm{i}$ henholdsvis nr. 5.1.1, 5.1.2, 5.2.2, 5.3.2, 5.3.3, 5.4.2, 5.6.2 og 5.7.1 i vedlegg V.

Bestemmelsene $\mathrm{i}$ første og annet ledd påvirker ikke de ervervede rettighetene nevnt $\mathrm{i}$ artikkel 23, 27, 33, 37, 39 og 49. 
2. Alle medlemsstater skal med henblikk på utøvelse av allmennmedisin innenfor rammen av medlemsstatens nasjonale trygdeordning, godkjenne kvalifikasjonsbevisene oppført $i$ nr. 5.1.4 i vedlegg $\mathrm{V}$, og som er utstedt til medlemsstatenes borgere av de andre medlemsstatene i samsvar med minstekravene til utdanning fastsatt i artikkel 28.

Bestemmelsene $\mathrm{i}$ forrige ledd påvirker ikke de ervervede rettighetene nevnt $\mathrm{i}$ artikkel 30 .

3. Alle medlemsstater skal godkjenne de kvalifikasjonsbeviser som jordmor tildelt medlemsstatenes borgere av de andre medlemsstatene, oppført i nr. 5.5.2 i vedlegg $\mathrm{V}$, som oppfyller minstekravene til utdanning nevnt i artikkel 40 og kriteriene fastsatt i artikkel 41, og skal med hensyn til adgang til og utøvelse av yrkesvirksomheten gi slike kvalifikasjonsbeviser samme virkning på medlemsstatens territorium som de kvalifikasjonsbevisene medlemsstaten selv utsteder. Denne bestemmelsen påvirker ikke de ervervede rettighetene nevnt i artikkel 23 og 43.

4. Medlemsstatene skal ikke være forpliktet til å gi virkning til kvalifikasjonsbeviser nevnt i nr. 5.6.2 i vedlegg $\mathrm{V}$, for etablering av nye apoteker som er åpne for allmennheten. Ved anvendelsen av dette nummer skal apoteker som har vært åpne i mindre enn tre år, også anses som nye apoteker.

5. Kvalifikasjonsbeviser som arkitekt nevnt i nr. 5.7.1 i vedlegg $\mathrm{V}$, som er underlagt automatisk godkjenning i henhold til nr. 1, skal bekrefte fullføring av en utdanning som ble påbegynt tidligst i løpet av det akademiske referanseåret nevnt i nevnte vedlegg.

6. Alle medlemsstater skal for adgang til og utøvelse av yrkesvirksomhet som lege, sykepleier med ansvar for alminnelig sykepleie, tannlege, veterinær, jordmor og farmasøyt kreve at utøveren er i besittelse av et kvalifikasjonsbevis nevnt $\mathrm{i}$ henholdsvis nr. 5.1.1, 5.1.2, 5.1.4, 5.2.2, 5.3.2, 5.3.3, 5.4.2, 5.5.2 og 5.6.2 i vedlegg V, som bekrefter at vedkommende i løpet av hele sin utdanning har ervervet de kunnskaper og ferdigheter som er nevnt i artikkel 24 nr. 3, artikkel 31 nr. 6, artikkel 34 nr. 3, artikkel 38 nr. 3, artikkel 40 nr. 3 og artikkel $44 \mathrm{nr} .3$.

Kunnskapene og ferdighetene nevnt i artikkel 24 nr. 3, artikkel 31 nr. 6, artikkel 34 nr. 3, artikkel 38 nr. 3, artikkel 40 nr. 3 og artikkel 44 nr. 3 kan endres etter framgangsmåten nevnt i artikkel $58 \mathrm{nr}$. 2 for å tilpasse dem til den vitenskapelige og tekniske utvikling.

Slike ajourføringer skal ikke for noen medlemsstats vedkommende medføre en endring av eksisterende prinsipper $\mathrm{i}$ yrkeslovgivningen når det gjelder utdanning og fysiske personers adgangsvilkår.

7. Alle medlemsstatene skal underrette Kommisjonen om de lover og forskrifter de vedtar med hensyn til utstedelse av kvalifikasjonsbeviser på det område dette kapittel omhandler. For kvalifikasjonsbeviser på området nevnt i avsnitt 8 skal denne underretningen i tillegg rettes til de andre medlemsstatene.

Kommisjonen skal offentliggjøre en egnet melding i Den europeiske unions tidende, og angi de betegnelsene som medlemsstatene har vedtatt for kvalifikasjonsbeviser og, der det er hensiktsmessig, det organ som utsteder kvalifikasjonsbeviset, den attesten som ledsager beviset samt tilsvarende yrkestittel $\mathrm{i}$ henholdsvis $\mathrm{nr}$. 5.1.1, 5.1.2, 5.1.4, 5.2.2, 5.3.2, 5.3.3, 5.4.2, 5.5.2, 5.6.2 og 5.7.1 i vedlegg V.

Artikkel 22

\section{Felles bestemmelser om utdanning}

Med hensyn til utdanningen nevnt i artikkel 24, 25, 28, 31, 34, $35,38,40,44$ og 46

a) kan medlemsstatene tillate utdanning på deltid på de vilkår som fastsettes av vedkommende myndigheter; disse myndighetene skal sikre at den samlede varigheten av og nivået og kvaliteten på denne utdanningen ikke er lavere enn for tilsvarende heltidsutdanning, og

b) etter hver enkelt medlemsstats særskilte framgangsmåte skal videreutdanning sikre at personer som har fullført sine studier, er i stand til å holde tritt med den yrkesfaglige utviklingen i den utstrekning dette er nødvendig for å opprettholde en sikker og effektiv yrkesutøvelse.

Artikkel 23

\section{Ervervede rettigheter}

1. Når kvalifikasjonsbeviser som lege som gir adgang til yrkesvirksomhet som lege med grunnutdanning og med spesialistutdanning, som sykepleier med ansvar for alminnelig sykepleie, som tannlege, som tannlege med spesialistutdanning, som veterinær, jordmor og farmasøyt som innehas av borgere i medlemsstatene, ikke oppfyller utdanningskravene nevnt i artikkel 24, 25, 31, 34, 35, 38, 40 og 44, skal alle medlemsstater - med forbehold for de ervervede rettighetene for de berørte yrkene - godkjenne kvalifikasjonsbeviser som er utstedt av disse medlemsstatene som tilstrekkelig bevis, dersom de bekrefter bestått fullført utdanning som ble påbegynt før referansedatoene fastsatt $\mathrm{i} \mathrm{nr} .5 .1 .1,5.1 .2,5.2 .2,5.3 .2,5.3 .3$, 5.4.2, 5.5.2 og 5.6.2 i vedlegg $\mathrm{V}$ og ledsages av en attest som bekrefter at innehaverne av disse kvalifikasjonsbevisene faktisk og rettmessig har utøvd denne virksomheten i minst tre sammenhengende år i løpet av de siste fem årene før attesten ble utstedt. 
2. De samme bestemmelsene får anvendelse på kvalifikasjonsbeviser som lege som gir adgang til yrkesaktivitet som lege med grunnutdanning og med spesialistutdanning, som sykepleier med ansvar for alminnelig sykepleie, som tannlege, som tannlege med spesialistutdanning, som veterinær, som jordmor og som farmasøyt, som er ervervet på den tidligere Tyske demokratiske republikks territorium, som ikke oppfyller alle minstekravene til utdanning fastsatt i artikkel 24, 25, 31, $34,35,38,40$ og 44, dersom disse bevisene bekrefter en bestått utdanning som ble påbegynt før

a) 3. oktober 1990 for leger med grunnutdanning, sykepleiere med ansvar for alminnelig sykepleie, tannleger, tannleger med spesialistutdanning, veterinærer, jordmødre og farmasøyter, og

b) 3. april 1992 for leger med spesialistutdanning.

Kvalifikasjonsbevisene nevnt i første ledd gir innehaveren rett til å utøve yrkesvirksomhet på hele Tysklands territorium på de samme vilkår som kvalifikasjonsbeviser utstedt av vedkommende tyske myndigheter nevnt i nr. 5.1.1, 5.1.2, 5.2.2, 5.3.2, 5.3.3, 5.4.2, 5.5.2 og 5.6.2 i vedlegg V.

3. Uten at det berører bestemmelsene i artikkel $37 \mathrm{nr}$. 1, skal alle medlemsstater godkjenne kvalifikasjonsbeviser som lege som gir adgang til yrkesvirksomhet som lege med grunnutdanning og med spesialistutdanning, som sykepleier med ansvar for alminnelig sykepleie, som veterinær, som farmasøyt, som jordmor og som arkitekt, som innehas av borgere i medlemsstatene og som er utstedt av det tidligere Tsjekkoslovakia eller, for Tsjekkia og Slovakia, der utdanningen ble påbegynt før 1. januar 1993, dersom myndighetene $i$ en av de to nevnte medlemsstatene bekrefter at disse kvalifikasjonsbevisene har samme rettslige gyldighet innenfor deres territorium som de kvalifikasjonsbevisene de selv utsteder og, når det gjelder arkitekter, som de kvalifikasjonsbevisene som er angitt for disse medlemsstatene i nr. 6 i vedlegg VI, når det gjelder adgang til yrkesvirksomhet som lege med grunnutdanning og spesialistutdanning, som sykepleier med ansvar for alminnelig sykepleie, som veterinær, som jordmor, som farmasøyt når det gjelder virksomheten nevnt $\mathrm{i}$ artikkel 45 nr. 2, og som arkitekt når det gjelder virksomheten nevnt $i$ artikkel 48 samt utøvelse av disse formene for virksomhet.

En slik bekreftelse skal ledsages av en attest utstedt av de samme myndighetene som bekrefter at disse personene faktisk og rettmessig har utøvd denne virksomheten på deres territorium i minst tre sammenhengende år i løpet av de fem årene før datoen for utstedelse av attesten.

4. Alle medlemsstater skal godkjenne kvalifikasjonsbeviser som lege som gir adgang til yrkesaktivitet som lege med grunnutdanning og med spesialistutdanning, som sykepleier med ansvar for alminnelig sykepleie, som tannlege, som tannlege med spesialistutdanning, som veterinær, som jordmor, som farmasøyt og som arkitekt, som innehas av borgere $i$ medlemsstatene og er utstedt av den tidligere Sovjetunionen, eller dersom utdanningen ble påbegynt

a) før 20. august 1991 for Estland,

b) før 21. august 1991 for Latvia,

c) før 11. mars 1990 for Litauen,

dersom myndighetene $i$ en av de tre nevnte medlemsstatene bekrefter at disse kvalifikasjonsbevisene har samme rettslige gyldighet innenfor deres territorium som de kvalifikasjonsbevisene de selv utsteder og, når det gjelder arkitekter, som de kvalifikasjonsbevisene som angis for disse medlemsstatene i nr. 6 i vedlegg VI, med hensyn til adgang til yrkesvirksomhet som lege med grunnutdanning og med spesialistutdanning, som sykepleier med ansvar for alminnelig sykepleie, som tannlege, som tannlege med spesialistutdanning, som veterinær, som jordmor, som farmasøyt når det gjelder virksomheten nevnt i artikkel 45 nr. 2 og som arkitekt når det gjelder virksomheten nevnt i artikkel 48 samt utøvelse av disse formene for virksomhet.

En slik bekreftelse skal ledsages av en attest utstedt av de samme vedkommende myndigheter som bekrefter at disse personene faktisk og rettmessig har utøvd den berørte virksomheten på deres territorium i minst tre sammenhengende år i løpet av de fem årene før datoen for utstedelse av attesten.

Når det gjelder kvalifikasjonsbeviser som veterinær utstedt av den tidligere Sovjetunionen eller der denne utdanningen ble påbegynt, for Estland, før 20. august 1991, skal bekreftelsen i forrige ledd ledsages av en attest utstedt av de samme estiske myndigheter som bekrefter at disse personene faktisk og rettmessig har utøvd den berørte virksomheten på deres territorium i minst fem sammenhengende år i løpet av de sju årene før datoen for utstedelse av attesten.

5. Alle medlemsstater skal godkjenne kvalifikasjonsbeviser som lege som gir adgang til yrkesvirksomhet som lege med grunnutdanning og med spesialistutdanning, som sykepleier med ansvar for alminnelig sykepleie, som tannlege, som tannlege med spesialistutdanning, som veterinær, som jordmor, som farmasøyt og som arkitekt, som innehas av borgere i medlemsstatene og som er utstedt av det tidligere Jugoslavia, eller der utdanningen når det gjelder Slovenia ble påbegynt før 25. juni 1991, der myndighetene i de to nevnte medlemsstatene bekrefter at disse kvalifikasjonsbevisene har samme rettslige gyldighet innenfor deres territorium som de kvalifikasjonsbevisene de selv utsteder og, når det gjelder arkitekter, som de kvalifikasjonsbevisene som er angitt for disse medlemsstatene i nr. 6 i vedlegg VI, når det gjelder adgang til yrkesvirksomhet som lege med grunnutdanning og med spesialistutdanning, som sykepleier med ansvar for alminnelig 
sykepleie, som tannlege, som tannlege med spesialistutdanning, som veterinær, som jordmor, som farmasøyt når det gjelder virksomheten nevnt $\mathrm{i}$ artikkel 45 nr. 2, og som arkitekt når det gjelder virksomheten nevnt $\mathrm{i}$ artikkel 48 samt utøvelse av disse formene for virksomhet.

En slik bekreftelse skal ledsages av en attest utstedt av samme vedkommende myndigheter som bekrefter at disse personene faktisk og rettmessig har utøvd den berørte virksomheten på deres territorium i minst tre sammenhengende år i løpet av de fem årene før datoen for utstedelsen av attesten.

6. Alle medlemsstater skal som tilstrekkelig bevis for borgere i medlemsstatene med kvalifikasjonsbeviser som lege, som sykepleier med ansvar for alminnelig sykepleie, som tannlege, som veterinær, som jordmor og som farmasøyt som ikke tilsvarer de titlene som er angitt for denne medlemsstaten i nr. 5.1.1, 5.1.2, 5.1.3, 5.1.4, 5.2.2, 5.3.2, 5.3.3, 5.4.2, 5.5.2 og 5.6.2 i vedlegg V, godkjenne kvalifikasjonsbeviser utstedt av disse medlemsstatene som ledsages av en attest utstedt av vedkommende myndigheter eller organer.

Av attesten nevnt i første ledd skal det framgå at disse kvalifikasjonsbevisene bekrefter at innehaveren har bestått en utdanning i samsvar med henholdsvis artikkel 24, 25, 28, 31, $34,35,38,40$ og 44, og at medlemsstaten som utstedte dem, sidestiller dem med dem som er oppført i nr. 5.1.1, 5.1.2, 5.1.3, 5.1.4, 5.2.2, 5.3.2, 5.3.3, 5.4.2, 5.5.2 og 5.6.2 i vedlegg V.

\section{AVSNITT 2}

\section{Lege}

Artikkel 24

\section{Medisinsk grunnutdanning}

1. Adgang til medisinsk grunnutdanning forutsetter et diplom eller en attest som gir adgang til de berørte studiene ved et universitet.

2. Den medisinske grunnutdanningen skal omfatte minst seks års studier eller 5500 timers teoretisk og praktisk undervisning ved et universitet eller under tilsyn av et universitet.

For personer som påbegynte sine studier før 1. januar 1972, kan utdanningen nevnt $\mathrm{i}$ første ledd omfatte seks måneders praktisk heltidsutdanning på universitetsnivå under tilsyn av vedkommende myndigheter.

3. Medisinsk grunnutdanning skal være en garanti for at vedkommende har ervervet følgende kunnskaper og ferdigheter:

a) tilstrekkelig kunnskap om de vitenskaper som utøvelse av legevirksomhet bygger på, samt en god forståelse av vitenskapelige metoder, herunder prinsippene for måling av biologiske funksjoner, vurdering av vitenskapelig fastlagte fakta og analyse av data,

b) tilstrekkelig forståelse av friske og syke menneskers anatomi, funksjoner og atferd samt av forbindelsene mellom menneskets helsetilstand og dets fysiske og sosiale omgivelser,

c) tilstrekkelig kunnskap om kliniske disipliner og praksis som gir legen et helhetlig bilde av psykiske og fysiske sykdommer, om utøvelse av legevirksomhet ut fra et forebyggende, diagnostisk og terapeutisk synspunkt samt om menneskets forplantning,

d) passende klinisk erfaring på sykehus under nødvendig tilsyn.

Artikkel 25

\section{Spesialistlegeutdanning}

1. Adgang til spesialistlegeutdanningen forutsetter fullføring og godkjenning av seks års studier som del av et studieprogram som nevnt i artikkel 24, der studenten har ervervet relevante grunnleggende medisinske kunnskaper.

2. Spesialistlegeutdanningen skal omfatte teoretisk og praktisk utdanning ved et universitet eller universitetssykehus eller, der dette er hensiktsmessig, ved en helseinstitusjon godkjent for dette formål av vedkommende myndigheter eller organer.

Medlemsstatene skal sikre at varigheten av spesialistlegeutdanningen nevnt i nr. 5.1.3 i vedlegg V, ikke er kortere enn varigheten fastsatt i nevnte nummer. Utdanningen skal gis under tilsyn av vedkommende myndigheter eller organer. Den skal omfatte studentens personlige deltaking $\mathrm{i}$ spesialistlegeutdanningen i den virksomhet og med det ansvar som de berørte tjenestene medfører.

3. Utdanningen skal gis på heltid ved bestemte institusjoner som er godkjent av vedkommende myndigheter. Den forutsetter deltaking $\mathrm{i}$ all medisinsk virksomhet på den avdelingen der utdanningen foregår, herunder vakter, slik at studenten under spesialistutdanning $\mathrm{i}$ hele den normale arbeidsuken og gjennom hele året bruker hele sin arbeidsinnsats på den praktiske og teoretiske utdanningen, etter de framgangsmåter som er fastsatt av vedkommende myndigheter. Disse stillingene skal følgelig avlønnes med et passende beløp.

4. Medlemsstatene skal gjøre utstedelse av kvalifikasjonsbeviser for spesialistlegeutdanning betinget av at utøveren innehar et kvalifikasjonsbeviser for medisinsk grunnutdanning nevnt $\mathrm{i}$ vedlegg $\mathrm{V}$ nr. 5.1.1.

5. Minstekravene til utdanningens varighet nevnt i nr. 5.1.3 i vedlegg $\mathrm{V}$ kan endres etter framgangsmåten nevnt $\mathrm{i}$ artikkel 58 nr. 2 for å tilpasse dem til den vitenskapelige og tekniske utvikling. 
Artikkel 26

\section{Betegnelser for spesialistlegeutdanninger}

Kvalifikasjonsbeviser som lege med spesialistutdanning som nevnt $\mathrm{i}$ artikkel 21, er de kvalifikasjonsbeviser som tildeles av vedkommende myndigheter eller organer nevnt $\mathrm{i}$ nr. 5.1.2 i vedlegg $\mathrm{V}$, som for den berørte spesialistlegeutdanningen tilsvarer de betegnelsene som anvendes $i$ de ulike medlemsstatene og som er nevnt i nr. 5.1.3 i vedlegg V.

Nye medisinske spesialiteter som er felles for minst to femdeler av medlemsstatene, kan oppføres i nr. 5.1.3 i vedlegg V, etter framgangsmåten nevnt i artikkel $58 \mathrm{nr}$. 2, for å ajourføre dette direktiv i lys av endringer i nasjonal lovgivning.

Artikkel 27

\section{Særlige ervervede rettigheter for leger med spesialistutdanning}

1. For leger med spesialistutdanning som tok sin spesialistutdanning på deltid som var omfattet av lover og forskrifter som var i kraft 20. juni 1975 og som påbegynte sin spesialistutdanning senest 31. desember 1983, kan en vertsstat kreve at deres kvalifikasjonsbeviser ledsages av en attest som bekrefter at de faktisk og rettmessig har utøvd virksomheten i minst tre sammenhengende år i løpet av de siste fem årene før av attesten ble utstedt.

2. Alle medlemsstater skal godkjenne kvalifikasjonsbeviset til leger med spesialistutdanning tildelt i Spania til leger som fullførte sin spesialistutdanning før 1. januar 1995, selv om denne utdanningen ikke oppfyller minstekravene til utdanning fastsatt i artikkel 25, dersom dette kvalifikasjonsbeviset ledsages av en attest utstedt av vedkommende spanske myndigheter som bekrefter at personen har bestått eksamen i særskilt yrkeskompetanse avholdt i forbindelse med de ekstraordinære godkjenningstiltakene i kongelig anordning 1497/99 for å sikre at personen har et kunnskaps- og ferdighetsnivå som er sammenlignbart med de leger som innehar et kvalifikasjonsbevis som lege med spesialistutdanning som er definert for Spania $\mathrm{i}$ nr. 5.1.2 og 5.1.3 i vedlegg V.

3. Alle medlemsstater som har opphevet sine lover og forskrifter om utstedelse av kvalifikasjonsbeviser som lege med spesialistutdanning som nevnt $\mathrm{i}$ nr. 5.1.2 og 5.1.3 i vedlegg $\mathrm{V}$, og som har vedtatt tiltak knyttet til ervervede rettigheter til fordel for statens egne borgere, skal gi andre medlemsstaters borgere rett til å dra fordel av disse tiltakene, dersom deres kvalifikasjonsbeviser var utstedt før datoen da vertsstaten sluttet å utstede slike beviser for den berørte spesialistutdanningen.

Datoene for oppheving av disse bestemmelsene framgår av nr. 5.1.3 i vedlegg V.

\section{Artikkel 28}

\section{Særskilt utdanning i allmennmedisin}

1. Adgang til særskilt utdanning $i$ allmennmedisin forutsetter fullføring og godkjenning av seks års studier som del av et studieprogram som nevnt $\mathrm{i}$ artikkel 24.

2. Den særskilte utdanningen i allmennmedisin som leder til tildeling av kvalifikasjonsbeviser utstedt før 1. januar 2006, skal omfatte minst to års studier på heltid. Når det gjelder kvalifikasjonsbeviser utstedt etter denne dato, skal utdanningen omfatte minst tre års studier på heltid.

Der studieprogrammet nevnt i artikkel 24 omfatter praktisk opplæring ved et godkjent sykehus med egnet utstyr og egnede tjenester innenfor allmennmedisin, hos en godkjent allmennpraktiker eller ved et godkjent legesenter innenfor primærhelsetjenesten, kan varigheten av denne praktiske opplæringen medregnes med høyst ett år i tidsrommet fastsatt i første ledd for utdanningsbeviser utstedt tidligst 1. januar 2006.

Alternativet $\mathrm{i}$ annet ledd skal bare kunne benyttes av medlemsstater der varigheten av den særskilte utdanningen $\mathrm{i}$ allmennmedisin per 1. januar 2001 er to år.

3. Den særskilte utdanningen i allmennmedisin skal foregå på heltid under tilsyn av vedkommende myndigheter eller organer. Den skal være mer praktisk enn teoretisk.

Den praktiske delen av utdanningen skal foregå dels i minst seks måneder på et godkjent sykehus med egnet utstyr og egnede tjenester, og dels i minst seks måneder hos en godkjent allmennpraktikers eller ved et godkjent legesenter innenfor primærhelsetjenesten.

Den praktiske delen av utdanningen skal foregå i samarbeid med andre helseinstitusjoner eller -organer innenfor allmennmedisin. Uten at det berører minsteperiodene fastsatt $i$ annet ledd kan imidlertid den praktiske delen av utdanningen i en periode på høyst seks måneder gis ved andre godkjente helseinstitusjoner eller -organer innenfor allmennmedisin. 
Utdanningen forutsetter studentens personlige deltaking i den faglige virksomhet og de ansvarsområder som påhviler de personene som studenten arbeider sammen med.

4. Medlemsstatene skal gjøre utstedelse av kvalifikasjonsbeviser for særskilt utdanning i allmennmedisin betinget av besittelse av et kvalifikasjonsbevis for medisinsk grunnutdanning som nevnt i vedlegg $\mathrm{V}$ nr. 5.1.1.

5. Medlemsstatene kan utstede et kvalifikasjonsbevis som nevnt $\mathrm{i}$ nr. 5.1.4 $\mathrm{i}$ vedlegg $\mathrm{V}$ til en lege som ikke har fullført den utdanningen som er fastsatt $i$ denne artikkel, men som har fullført en annen supplerende utdanning bekreftet ved et kvalifikasjonsbevis utstedt av vedkommende myndigheter i en medlemsstat. De kan imidlertid ikke utstede kvalifikasjonsbeviser med mindre de bekrefter et kunnskapsnivå som tilsvarer den kunnskap som oppnås gjennom utdanningen fastsatt i denne artikkel.

Medlemsstatene skal blant annet fastsette i hvilket omfang søkerens allerede ervervede supplerende utdanning og yrkeserfaring kan erstatte den utdanningen som er fastsatt $i$ denne artikkel.

Medlemsstatene kan bare utstede kvalifikasjonsbeviser som nevnt i nr. 5.1.4 i vedlegg $\mathrm{V}$ dersom søkeren har fått minst seks måneders erfaring i allmennmedisin hos en allmennpraktiserende lege eller på et legesenter for primærhelsetjenester som nevnt i nr. 3 .

\section{Artikkel 29}

\section{Utøvelse av yrkesvirksomhet som allmennpraktiserende lege}

Med forbehold for bestemmelsene om ervervede rettigheter skal medlemsstatene for utøvelse av yrkesvirksomhet som allmennpraktiserende lege innenfor medlemsstatens nasjonale trygdeordning kreve et av kvalifikasjonsbevisene nevnt $i$ nr. 5.1.4 i vedlegg V.

Medlemsstatene kan unnta personer som er i ferd med å gjennomføre særskilt utdanning i allmennmedisin fra dette vilkåret.

\section{Artikkel 30}

\section{Særlige ervervede rettigheter for allmennpraktiserende leger}

1. Alle medlemsstater skal fastsette de ervervede rettighetene. De skal imidlertid anerkjenne som en ervervet rettighet retten til å utøve virksomhet som allmennpraktiserende lege innenfor medlemsstatens nasjonale trygdeordning, uten kvalifikasjonsbeviset nevnt i nr. 5.1.4 i vedlegg V, dersom legen har denne rettigheten på referansedatoen fastsatt i nevnte nummer i henhold til bestemmelser om legeyrket som gir adgang til yrkesvirksomhet som lege med grunnutdanning, og på nevnte dato er etablert på medlemsstatens territorium $\mathrm{i}$ henhold til bestemmelsene i artikkel 21 eller 23 .

Vedkommende myndigheter i alle medlemsstater skal på anmodning utstede en attest som bekrefter innehaverens rett til å utøve yrkesvirksomhet som allmennpraktiserende lege innenfor medlemsstatens nasjonale trygdeordning uten kvalifikasjonsbeviset nevnt i nr. 5.1.4 i vedlegg V, dersom legen har ervervede rettigheter i henhold til første ledd.

2. Alle medlemsstater skal godkjenne attestene som er nevnt i nr. 1 annet ledd og er utstedt til medlemsstaters borgere av andre medlemsstater, og skal gi slike attester samme virkning på sitt territorium som de kvalifikasjonsbeviser som medlemsstaten selv utsteder og som gir adgang til å utøve virksomhet som allmennpraktiserende lege innenfor medlemsstatens nasjonale trygdeordning.

\section{AVSNITT 3}

\section{Sykepleiere med ansvar for alminnelig sykepleie}

$$
\text { Artikkel } 31
$$

\section{Utdanning for sykepleiere med ansvar for alminnelig sykepleie}

1. Adgang til utdanning for sykepleiere med ansvar for alminnelig sykepleie forutsetter fullført allmennutdanning på ti år, bekreftet ved et diplom, en attest eller et annet kvalifikasjonsbevis utstedt av vedkommende myndigheter eller organer i en medlemsstat eller en attest som bekrefter bestått adgangseksamen på tilsvarende nivå til sykepleierskole.

2. Utdanning av sykepleiere med ansvar for alminnelig sykepleie skal gis på heltid, og skal omfatte minst det programmet som er beskrevet i nr. 5.2.1 i vedlegg V.

Innholdet inr. 5.2.1 i vedlegg $\mathrm{V}$ kan endres etter framgangsmåten nevnt i artikkel $58 \mathrm{nr}$. 2 for å tilpasse det til den vitenskapelige og tekniske utvikling.

Slike ajourføringer kan ikke for noen medlemsstats vedkommende medføre noen endring av eksisterende prinsipper i yrkeslovgivningen når det gjelder utdanning og fysiske personers adgangsvilkår.

3. Utdanning av sykepleiere med ansvar for alminnelig sykepleie skal omfatte minst tre års studier eller 4600 timer med teoretisk og klinisk utdanning, hvorav den teoretiske utdanningen utgjør minst en tredel og den kliniske utdanningen minst halvparten av utdanningens samlede minste varighet. Medlemsstatene kan gi delvis unntak for personer som har gjennomgått en del av denne utdanningen i forbindelse med andre utdanninger på minst tilsvarende nivå. 
Medlemsstatene skal sikre at institusjoner som utdanner sykepleiere, er ansvarlige for samordningen av den teoretiske og kliniske utdanningen gjennom hele studieprogrammet.

4. Teoretisk utdanning er den delen av sykepleierutdanningen der sykepleierstudentene får de yrkeskunnskaper, den innsikt og de ferdigheter som er nødvendig for å organisere, gi og vurdere generell helse- og sykepleie. Utdanningen skal gis av lærer i sykepleiefag og av andre kompetente personer, på sykepleierskoler og andre utdanningssteder utvalgt av utdanningsinstitusjonen

5. Klinisk utdanning er den delen av sykepleierutdanningen der sykepleierstudentene, som en del av et lag og i direkte kontakt med friske eller syke enkeltpersoner og/eller grupper, lærer å organisere, yte og vurdere den nødvendige samlede sykepleie, på grunnlag av den kunnskap og de ferdigheter de har tilegnet seg. Sykepleierstudenten skal ikke bare lære å arbeide i lag, men også lære hvordan et lag ledes og hvordan alminnelig sykepleie organiseres, herunder helseundervisning for enkeltpersoner og små grupper, innenfor helseinstitusjonen eller i samfunnet.

Denne utdanningen skal foregå på sykehus og andre helseinstitusjoner og i samfunnet, under tilsyn av lærere i sykepleiefag, i samarbeid med og assistert av andre kvalifiserte sykepleiere. Annet kvalifisert personell kan også ta del i undervisningen.

Sykepleierstudenter skal delta i virksomheten ved den berørte avdelingen i den utstrekning denne virksomheten er hensiktsmessig for deres utdanning, slik at de kan lære å påta seg det ansvar som sykepleiefaget innebærer.

6. Utdanning av sykepleiere med ansvar for alminnelig sykepleie skal være en garanti for at vedkommende har tilegnet seg følgende kunnskaper og ferdigheter:

a) tilstrekkelige kunnskaper om de vitenskaper som alminnelig sykepleie er basert på, herunder tilstrekkelig forståelse av friske og syke menneskers anatomi, funksjoner og atferd samt av forbindelsene mellom menneskets helsetilstand og dets fysiske og sosiale omgivelser,

b) tilstrekkelige kunnskaper om yrkets art og etikk og om de allmenne prinsippene for helse og sykepleie,

c) tilstrekkelig klinisk erfaring; slik erfaring, som bør velges ut fra sin verdi i utdanningen, bør tilegnes under tilsyn av kvalifisert sykepleiepersonell og på steder der antallet kvalifiserte personer og utstyr er egnet for pasientpleie, d) evne til å delta i den praktiske utdanningen av helsepersonell og erfaring i å samarbeide med dette personellet,

e) erfaring i å samarbeide med annet helsepersonell.

Artikkel 32

\section{Utøvelse av yrkesvirksomhet som sykepleier med ansvar for alminnelig sykepleie}

I dette direktiv menes med yrkesvirksomhet som sykepleier med ansvar for alminnelig sykepleie den virksomhet som utøves på yrkesmessig grunnlag, og som er nevnt i nr. 5.2.2 i vedlegg $\mathrm{V}$.

\section{Artikkel 33}

\section{Særlige ervervede rettigheter for sykepleiere med ansvar for alminnelig sykepleie}

1. For at de alminnelige reglene for ervervede rettigheter kan få anvendelse på sykepleiere med ansvar for alminnelig sykepleie, skal virksomheten nevnt i artikkel 23 ha omfattet fullt ansvar for planlegging, organisering og administrasjon av pasientpleie.

2. Nårdetgjelderpolskekvalifikasjonsbeviser for sykepleiere med ansvar for alminnelig sykepleie, får bare følgende bestemmelser om ervervede rettigheter anvendelse. Når det gjelder borgere i medlemsstater som har kvalifikasjonsbeviser som sykepleier med ansvar for alminnelig sykepleie utstedt av, eller dersom utdanningen startet $i$, Polen for 1 . mai 2004 og ikke oppfyller de minstekravene til utdanning som er fastsatt i artikkel 31, skal medlemsstatene godkjenne følgende kvalifikasjonsbeviser som sykepleier med ansvar for alminnelig sykepleie som tilstrekkelig bevis dersom det ledsages av en attest som bekrefter at disse personene faktisk og rettmessig har utøvd virksomhet som sykepleier med ansvar for alminnelig sykepleie i Polen i den perioden som er angitt nedenfor:

a) kvalifikasjonsbevis som sykepleier på universitetsnivå (dyplom licencjata pielćgniarstwa): minst tre sammenhengende år i løpet av de siste fem årene før attestens utstedelsesdato,

b) kvalifikasjonsbevis som sykepleier som bekrefter fullføring av utdanning etter videregående utdanning ved en medisinsk fagskole (dyplom pielęgniarki albo pielęgniarki dyplomowanej): minst fem sammenhengende år i løpet av de siste sju årene før attestens utstedelsesdato. 
Denne virksomhet skal ha omfattet fullt ansvar for planlegging, organisering og administrasjon av pasientpleie.

3. Medlemsstatene skal godkjenne kvalifikasjonsbeviser som sykepleier utstedt i Polen til sykepleiere som fullførte sin utdanning før 1. mai 2004, uten å oppfylle minstekravene til utdanning fastsatt $\mathrm{i}$ artikkel 31 , dersom de bevitnes av et diplom på bachelornivå som er oppnådd på grunnlag av et særlig kompletteringsprogram i henhold til artikkel 11 i polsk lov av 20. april 2004 om endring av loven om yrkene sykepleier og jordmor og om visse andre rettsakter (republikken Polens offisielle kunngjøringsblad av 30. april 2004 nr. 92, pos. 885) og helseministerens forordning av 11. mai 2004 om nærmere vilkår for utdanning av sykepleiere og jordmødre som innehar et eksamensbevis fra videregående skole (avsluttende eksamen — «matura») og som har bestått eksamen ved et medisinsk gymnas eller fagskole som underviser i sykepleier- og jordmoryrket (republikken Polens offisielle kunngjøringsblad av 13. mai $2004 \mathrm{nr}$. 110, pos. 1170), for å kontrollere at vedkommende har et kunnskapsog kompetansenivå som er sammenlignbart med nivået for jordmødre med de kvalifikasjoner som, når det gjelder Polen, er definert i nr. 5.5.2 i vedlegg $\mathrm{V}$.

AVSNITT 4

\section{Tannleger}

Artikkel 34

\section{Grunnutdanning for tannleger}

1. Adgang til grunnutdanning for tannleger forutsetter at kandidaten innehar et diplom eller en attest som gir rett til adgang til de berørte studiene ved universiteter eller høyskoler på et nivå som er godkjent som tilsvarende i en medlemsstat.

2. Grunnutdanning for tannleger skal omfatte $\mathrm{i}$ alt minst fem års teoretiske og praktiske studier på heltid, med minst det studieprogrammet som er beskrevet i nr. 5.3.1 i vedlegg V, ved et universitet, på en høyskole som er godkjent for å være på tilsvarende nivå eller under tilsyn av et universitet.

Innholdet i nr. 5.3.1 i vedlegg V kan endres etter framgangsmåten nevnt i artikkel $58 \mathrm{nr}$. 2 for å tilpasse det til den vitenskapelige og tekniske utvikling.

Slike ajourføringer kan ikke for noen medlemsstats vedkommende medføre noen endring av de eksisterende prinsippene $\mathrm{i}$ yrkeslovgivningen når det gjelder utdanning og fysiske personers adgangsvilkår.
3. Grunnutdanning for tannleger skal være en garanti for at vedkommende har tilegnet seg følgende kunnskaper og ferdigheter:

a) tilstrekkelig kunnskap om de vitenskaper som tannlegevirksomhet bygger på samt en god forståelse av vitenskapelige metoder, herunder prinsippene for måling av biologiske funksjoner, vurdering av vitenskapelig fastlagte fakta og analyse av data,

b) tilstrekkelig kunnskap om friske og syke menneskers allmenntilstand, fysiologi og adferd samt til det fysiske og sosiale miljøs innvirkning på menneskets helsetilstand, i den grad disse forhold påvirker tannlegevirksomheten,

c) tilstrekkelig kunnskap om tennenes, munnens, kjevenes og det omkringliggende vevs oppbygning og funksjon, både i frisk og syk tilstand, samt til forbindelsen mellom disse forhold og pasientens allmenne helsetilstand og fysiske og sosiale velvære,

d) tilstrekkelig kunnskap om kliniske disipliner og metoder som gir tannlegen et helhetlig bilde av misdannelser, skader og sykdommer i tennene, munnen, kjevene og det omkringliggende vev samt om forebyggende, diagnostisk og terapeutisk tannlegevirksomhet,

e) hensiktsmessig klinisk erfaring under passende tilsyn.

Denne utdanningen skal gi vedkommende de ferdigheter som er nødvendig for å utøve enhver virksomhet som innebærer forebygging, diagnose og behandling av misdannelser og sykdommer i tennene, munnen, kjevene og det omkringliggende vev.

\section{Artikkel 35}

\section{Spesialistutdanning for tannleger}

1. Adgang til spesialistutdanning for tannleger forutsetter enten fullføring og godkjenning av fem års teoretisk og praktisk undervisning innenfor rammen av studieprogrammet nevnt $\mathrm{i}$ artikkel 34, eller at vedkommende innehar de dokumentene som er nevnt i artikkel 23 og 37 .

2. Spesialistutdanning for tannleger skal omfatte teoretisk og praktisk undervisning på et universitet, et behandlingssenter for undervisning og forskning eller, der dette er hensiktsmessig, på en helseinstitusjon som er godkjent for dette formål av vedkommende myndigheter eller organer.

Spesialistutdanning for tannleger skal ha en varighet på minst tre år på heltid under tilsyn av vedkommende myndigheter eller organer. Den skal innebære at kandidaten under spesialistutdanning personlig deltar i de berørte institusjoners virksomhet og ansvarsområder. 
Minstekravene til utdanningens varighet nevnt $\mathrm{i}$ annet ledd kan endres etter framgangsmåten nevnt i artikkel $58 \mathrm{nr}$. 2 for å tilpasse dem til den vitenskapelige og tekniske utvikling.

3. Medlemsstatene skal gjøre utstedelse av kvalifikasjonsbeviser for spesialistutdanning for tannleger betinget av at utøveren innehar et kvalifikasjonsbevis for grunnutdanning for tannleger som nevnt i nr. 5.3.2 i vedlegg V.

Artikkel 36

\section{Utøvelse av yrkesvirksomhet som tannlege}

1. I dette direktiv menes med yrkesvirksomhet som tannlege den virksomhet som er definert i nr. 3, og som utøves under yrkestitlene angitt i nr. 5.3.2 i vedlegg V.

2. Yrkesvirksomheten som tannlege bygger på tannlegeutdanningen nevnt i artikkel 34, og utgjør et særskilt yrke atskilt fra yrket som lege eller spesialist. Utøvelse av yrkesvirksomhet som tannlege forutsetter besittelse av et av kvalifikasjonsbevisene som er nevnt i nr. 5.3.2 i vedlegg V. Innehavere av slike kvalifikasjonsbeviser skal sidestilles med dem om er omfattet av artikkel 23 eller 37.

3. Medlemsstatene skal påse at tannleger generelt skal ha adgang til og utøve virksomhet som innebærer forebygging, diagnose og behandling av misdannelser og sykdommer $\mathrm{i}$ tennene, munnen, kjevene og omkringliggende vev i samsvar med de forskrifter og yrkesetiske regler som gjelder på referansedatoene nevnt i nr. 5.3.2 i vedlegg V.

Artikkel 37

\section{Særlige ervervede rettigheter for tannleger}

1. Alle medlemsstater skal, når det gjelder utøvelse av yrkesvirksomhet som tannlege under yrkestitlene angitt $\mathrm{i}$ nr. 5.3.2 i vedlegg V, godkjenne kvalifikasjonsbeviser som lege utstedt i Italia, Spania, Østerrike, Tsjekkia og Slovakia til personer som påbegynte sin medisinske utdanning senest på den referansedato som er fastsatt i nevnte vedlegg for den berørte medlemsstaten, og som er ledsaget av en attest utstedt av vedkommende myndigheter i denne medlemsstaten.

Det skal framgå av attesten at følgende to vilkår er oppfylt:

a) Personeneharfaktisk, rettmessigogsom hovedbeskjeftigelse utøvd virksomheten nevnt $\mathrm{i}$ artikkel $36 \mathrm{i}$ den berørte medlemsstaten i minst tre sammenhengende år i løpet av de siste fem årene før attesten ble utstedt.

b) Personene har tillatelse til å utøve nevnte virksomhet på de samme vilkår som innehavere av kvalifikasjonsbeviser som angis for denne medlemsstaten i nr. 5.3.2 i vedlegg V.

Personer som har bestått minst tre års studier, bekreftet av vedkommende myndigheter $\mathrm{i}$ den berørte medlemsstaten som å tilsvare utdanningen nevnt i artikkel 34 , skal være unntatt fra kravet om tre års praktisk yrkeserfaring som nevnt $\mathrm{i}$ annet ledd bokstav a).

Når det gjelder Tsjekkia og Slovakia, skal kvalifikasjonsbeviser som er ervervet i det tidligere Tsjekkoslovakia, godkjennes på samme måte som tsjekkiske og slovakiske kvalifikasjonsbeviser og på samme vilkår som i forrige ledd.

2. Alle medlemsstater skal godkjenne kvalifikasjonsbeviser som lege som er utstedt i Italia til personer som påbegynte sin medisinske universitetsutdanning mellom 28. januar 1980 og 31. desember 1984, og som er ledsaget av en attest utstedt av vedkommende italienske myndigheter.

Det skal framgå av attesten at følgende tre vilkår er oppfylt:

a) Personene har bestått den relevante egnethetsprøven som avholdes av vedkommende italienske myndigheter for å kontrollere at personene har et kunnskaps- og ferdighetsnivå som tilsvarer nivået for innehavere av de kvalifikasjonsbevisene som er oppført for Italia i nr. 5.3.2 i vedlegg $\mathrm{V}$.

b) Atpersonene faktisk, rettmessig og som hovedbeskjeftigelse har utøvd virksomheten nevnt i artikkel 36 i Italia i minst tre sammenhengende år i løpet av de siste fem årene før attesten ble utstedt.

c) At personene har tillatelse til å utøve, eller faktisk, rettmessig og som hovedbeskjeftigelse utøver, den virksomhet som er nevnt i artikkel 36, på samme vilkår som innehavere av de kvalifikasjonsbeviser som er oppført for Italia i nr. 5.3.2 i vedlegg V.

Personer som har bestått minst tre års studier, bekreftet av vedkommende myndigheter som å tilsvare utdanningen nevnt i artikkel 34, skal være unntatt fra kravet om egnethetsprøven nevnt $\mathrm{i}$ annet ledd bokstav a).

Personer som påbegynte sin medisinske universitetsutdanning etter 31. desember 1984, skal sidestilles med ovennevnte personer, forutsatt at de ovennevnte tre års studier var påbegynt før 31. desember 1994. 


\section{AVSNITT 5}

\section{Veterinærer}

Artikkel 38

\section{Veterinærutdanning}

1. Veterinærutdanningen skal omfatte til sammen minst fem års teoretiske og praktiske studier på heltid ved et universitet, ved en høyskole som er godkjent for å være på tilsvarende nivå eller under tilsyn av et universitet, og som omfatter minst det studieprogrammet som er beskrevet i nr. 5.4.1 i vedlegg V.

Innholdet i nr. 5.4.1 i vedlegg V kan endres etter framgangsmåten nevnt i artikkel $58 \mathrm{nr}$. 2 for å tilpasse det til den vitenskapelige og tekniske utvikling.

Slike ajourføringer kan ikke for noen medlemsstats vedkommende medføre noen endring av de eksisterende prinsippene i yrkeslovgivningen når det gjelder utdanning og fysiske personers adgangsvilkår.

2. Adgang til veterinærutdanningen forutsetter besittelse av et diplom eller en attest som gir innehaveren rett til å studere ved det berørte studiet ved universiteter eller høyskoler godkjent av en medlemsstat som å være på tilsvarende nivå når det gjelder dette studiet.

3. Veterinærutdanningen skal være en garanti for at vedkommende har tilegnet seg følgende kunnskaper og ferdigheter:

a) tilstrekkelig kunnskap om de vitenskaper som virksomheten som veterinær bygger på

b) tilstrekkelig kunnskap om friske dyrs anatomi og funksjoner, skjøtsel av dyr, om forplantning og hygiene generelt samt om fôring, herunder teknologi involvert i framstilling og oppbevaring av fôr som svarer til dyrenes behov,

c) tilstrekkelig kunnskap om dyrs atferd og dyrevern,

d) tilstrekkelig kunnskap om årsaker, art, forløp, virkninger, diagnose og behandling av sykdommer hos dyr, enten hver for seg eller i grupper, herunder spesialkunnskap om de sykdommer som kan overføres til mennesker,

e) tilstrekkelig kunnskap om forebyggende medisin,

f) tilstrekkelig kunnskap om hygiene og teknologi involvert i produksjon og framstilling av samt handel med fôrvarer eller næringsmidler av animalsk opprinnelse beregnet på konsum, g) tilstrekkelig kunnskap om lover og forskrifter om ovennevnte emner,

h) tilstrekkelig klinisk og annen praktisk erfaring under egnet tilsyn.

\section{Artikkel 39}

\section{Særlige ervervede rettigheter for veterinærer}

Uten at det berører artikkel $23 \mathrm{nr}$. 4, og med hensyn til borgere i andre medlemsstater som har kvalifikasjonsbeviser som veterinær utstedt av, eller utdanning som ble påbegynt i, Estland før 1. mai 2004, skal medlemsstatene godkjenne kvalifikasjonsbeviser som veterinær, dersom det ledsages av en attest som bekrefter at personen faktisk og rettmessig har utøvd virksomheten i Estland i minst fem sammenhengende år i løpet av de siste sju årene før attesten ble utstedt.

\section{AVSNITT 6}

\section{Jordmor}

Artikkel 40

\section{Jordmorutdanning}

1. Jordmorutdanningen skal samlet omfatte minst følgende:

a) en særlig jordmorutdanning på heltid som består av minst tre år med teoretiske og praktiske studier (utdanningsvei I) som omfatter minst det studieprogrammet som er beskrevet i nr. 5.5.1 i vedlegg V, eller

b) en særlig jordmorutdanning på heltid med en varighet på 18 måneder (utdanningsvei II) som omfatter minst det studieprogrammet som er beskrevet i nr. 5.5.1 i vedlegg V og som ikke inngikk i tilsvarende undervisning innenfor utdanningen av sykepleiere med ansvar for alminnelig sykepleie.

Medlemsstatene skal sikre at institusjoner som utdanner jordmødre, er ansvarlige for samordningen av teori og praksis i hele studieprogrammet.

Innholdet inr. 5.5.1 i vedlegg V kan endres etter framgangsmåten nevnt i artikkel $58 \mathrm{nr}$. 2 for å tilpasse det til den vitenskapelige og tekniske utvikling.

Slike ajourføringer skal ikke for noen medlemsstats vedkommende medføre noen endring av de eksisterende prinsippene i yrkeslovgivningen når det gjelder utdanning og fysiske personers adgangsvilkår. 
2. Adgang til jordmorutdanningen skal være betinget av ett av følgende vilkår:

a) fullføring av minst ti års allmenn skoleutdanning for utdanningsvei I, eller

b) besittelse av et kvalifikasjonsbevis for sykepleier med ansvar for alminnelig sykepleie som nevnt i nr. 5.2.2 i vedlegg $\mathrm{V}$ for utdanningsvei II.

3. Jordmorutdanningen skal være en garanti for at vedkommende har tilegnet seg følgende kunnskaper og ferdigheter:

a) tilstrekkelig kunnskap om de vitenskaper som jordmorvirksomheten bygger på, særlig obstetrikk og gynekologi,

b) tilstrekkelig kunnskap om yrkets etikk og lovgivning,

c) inngående kunnskaper om biologiske funksjoner, obstetrisk og neonatal anatomi og fysiologi samt kunnskap om sammenhengen mellom menneskets helse og dets fysiske og sosiale miljø og dets adferd,

d) tilstrekkelig klinisk erfaring ervervet ved godkjente institusjoner under tilsyn av personale som er kvalifisert innenfor jordmorvirksomhet og obstetrikk,

e) tilstrekkelig innsikt i utdanning av helsepersonell og erfaring i samarbeid med slikt personell.

\section{Artikkel 41}

\section{Framgangsmåter for godkjenning av kvalifikasjonsbeviser som jordmor}

1. Kvalifikasjonsbeviser som jordmor, som nevnt i nr. 5.5.2 i vedlegg $\mathrm{V}$, skal godkjennes automatisk i henhold til artikkel 21 dersom de oppfyller ett av følgende kriterier:

a) heltids jordmorutdanning på minst tre år som

i) enten forutsetter besittelse av et diplom, en attest eller annet kvalifikasjonsbevis som gir adgang til universiteter eller høyskoler eller som garanterer et tilsvarende kunnskapsnivå, eller

ii) som etterfølges av to års yrkespraksis som det er utstedt en attest for i samsvar med nr. 2,

b) heltids jordmorutdanning i minst to år eller 3600 timer som forutsetter besittelse av et kvalifikasjonsbevis for sykepleier med ansvar for alminnelig sykepleie som nevnt i nr. 5.2.2 i vedlegg V,

c) heltids jordmorutdanning $\mathrm{i}$ minst 18 måneder eller 3000 timer som forutsetter besittelse av et kvalifikasjonsbevis for sykepleier med ansvar for alminnelig sykepleie som nevnt i nr. 5.2.2 i vedlegg V, og som er etterfulgt av ett års yrkespraksis som det er utstedt en attest for i samsvar med nr. 2.

2. Attesten nevnt i nr. 1 skal utstedes av vedkommende myndigheter i hjemstaten. Den skal bekrefte at innehaveren etter å ha oppnådd kvalifikasjonsbeviset som jordmor, på tilfredsstillende måte har utført alle former for jordmorvirksomhet $\mathrm{i}$ en tilsvarende periode ved et sykehus eller en helseinstitusjon godkjent for dette formål.

Artikkel 42

\section{Utøvelse av yrkesvirksomhet som jordmor}

1. Bestemmelsene i dette avsnitt får anvendelse på virksomhet som jordmor slik den er definert av hver enkelt medlemsstat, med forbehold for nr. 2, og som utøves under yrkestitlene angitt i nr. 5.5.2 i vedlegg V.

2. Medlemsstatene skal påse at jordmødre har rett til å få adgang til og utøve minst følgende virksomhet:

a) gi gode opplysninger og råd om familieplanlegging,

b) konstatere graviditet og overvåke normale svangerskap, foreta de undersøkelser som er nødvendige for å overvåke utviklingen av normale svangerskap,

c) forskrive eller gi råd om de undersøkelser som er nødvendige for tidligst mulig å diagnostisere risikosvangerskap,

d) lage et program for framtidige foreldres forberedelse til sin rolle, sørge for en fullstendig forberedelse til fødselen samt gi råd om hygiene og ernæring,

e) pleie og bistå moren under fødselen og overvåke fosterets tilstand i livmoren ved hjelp av egnede kliniske og tekniske midler,

f) forestå spontane fødsler, herunder om nødvendig foreta episiotomi, og i hastetilfeller bistå ved setefødsel,

g) gjenkjenne tegn hos mor eller barn som tyder på unormale forhold som gjør det nødvendig med henvisning til lege samt bistå legen om nødvendig; treffe nødvendige nødtiltak i legens fravær, særlig manuell morkakeløsning, eventuelt etterfulgt av manuell undersøkelse av livmoren, 
h) undersøke og ta seg av den nyfødte, ta alle nødvendige initiativer og eventuelt foreta øyeblikkelig gjenopplivning,

i) pleie og overvåke morens tilstand i tiden etter fødselen, og gi moren alle nødvendige råd om spedbarnsstell slik at hun kan sikre det nyfødte barnet en best mulig utvikling,

j) utføre behandling forskrevet av lege,

k) utarbeide nødvendige skriftlige rapporter.

Artikkel 43

\section{Særlige ervervede rettigheter for jordmødre}

1. Kvalifikasjonsbevis som jordmor utstedt til borgere i medlemsstatene som oppfyller alle minstekravene til utdanning fastsatt $\mathrm{i}$ artikkel 40 , men som i henhold til artikkel 41 ikke blir godkjent med mindre beviset ledsages av en attest om yrkespraksis som nevnt i artikkel 41 nr. 2, skal av alle medlemsstater godkjennes som tilstrekkelig bevis dersom kvalifikasjonsbeviset er utstedt av medlemsstatene før referansedatoen nevnt i nr. 5.5.2 i vedlegg $\mathrm{V}$ og ledsaget av en attest som bekrefter at disse borgerne faktisk og rettmessig har utøvd denne virksomheten i minst to sammenhengende år i løpet av de siste fem årene før attesten ble utstedt.

2. Vilkårene i nr. 1 får anvendelse på borgere i de medlemsstatene som har kvalifikasjonsbeviser som jordmor som bekrefter fullført utdanning på territoriet til det tidligere Øst-Tyskland og som oppfyller alle minstekravene til utdanning fastsatt $\mathrm{i}$ artikkel 40, men der kvalifikasjonsbeviset i henhold til artikkel 41 ikke blir godkjent med mindre det ledsages av attesten om yrkeserfaring nevnt $\mathrm{i}$ artikkel $41 \mathrm{nr}$. 2 som bekrefter et utdanningsforløp som begynte før 3. oktober 1990.

3. Når det gjelder polske kvalifikasjonsbeviser som jordmor, får bare følgende bestemmelser om ervervede rettigheter anvendelse.

Når det gjelder medlemsstaters borgere med kvalifikasjonsbevis som jordmor utstedt av, eller hvis utdanning ble påbegynt $i$, Polen før 1. mai 2004 og som ikke oppfyller minstekravene til utdanning fastsatt $\mathrm{i}$ artikkel 40 , skal medlemsstatene godkjenne følgende kvalifikasjonsbevis som jordmor dersom det ledsages av en attest som bekrefter at disse personene faktisk og rettmessig har utøvd virksomhet som jordmor i den perioden som er angitt nedenfor:

a) kvalifikasjonsbevis som jordmor på universitetsnivå (dyplom licencjata położnictwa): minst tre sammenhengende år i løpet av de siste fem årene før attesten ble utstedt,

b) kvalifikasjonsbevis som jordmor som bekrefter fullføring av utdanning etter videregående utdanning ved en medisinsk fagskole (dyplom położnej): minst fem sammenhengende år i løpet av de siste sju årene før attesten ble utstedt,

4. Medlemsstatene skal godkjenne kvalifikasjonsbeviser som jordmor utstedt i Polen til jordmødre som fullførte sin utdanning før 1. mai 2004 uten å oppfylle minstekravene til utdanning fastsatt $\mathrm{i}$ artikkel 40 , bekreftet av et diplom på bachelornivå som er ervervet på grunnlag av et spesielt kompletteringsprogram i henhold til artikkel 11 i lov av 20 . april 2004 om endring av loven om yrkene sykepleier og jordmor og om visse andre rettsakter (Republikken Polens offisielle kunngjøringsblad av 30. april 2004 nr. 92, pos. 885), og helseministerens forordning av 11. mai 2004 om nærmere vilkår for utdanning av sykepleiere og jordmødre som innehar et eksamensbevis fra videregående skole (avsluttende eksamen — «matura») og som har bestått eksamen ved et medisinsk gymnas eller fagskole som underviser i sykepleier- og jordmoryrket (Republikken Polens offisielle kunngjøringsblad av 13. mai $2004 \mathrm{nr}$. 110, pos. 1170), for å kontrollere at vedkommende har et kunnskaps- og kompetansenivå som er sammenlignbart med nivået for jordmødre med de kvalifikasjoner som, når det gjelder Polen, er angitt i nr. 5.5.2 i vedlegg $\mathrm{V}$.

\section{AVSNITT 7}

\section{Farmasøyt}

\section{Artikkel 44}

\section{Farmasøytutdanning}

1. Adgang til utdanning som farmasøyt forutsetter besittelse av et diplom eller en attest som gir adgang til de berørte studiene ved universiteter eller høyskoler på et nivå som er godkjent som tilsvarende i en medlemsstat.

2. Kvalifikasjonsbevis som farmasøyt skal bekrefte minst fem års utdanning, som omfatter minst

a) fire års heltids teoretisk og praktisk utdanning ved et universitet eller en høyskole på et nivå som er godkjent som tilsvarende, eller under tilsyn av et universitet,

b) seks måneders praktikanttid i et apotek som er åpent for allmennheten eller ved et sykehus, under tilsyn av sykehusets farmasøytiske avdeling. 
Dette utdanningsforløpet skal omfatte minst det studieprogrammet som er beskrevet $\mathrm{i}$ vedlegg $\mathrm{V} \mathrm{nr}$. 5.6.1. Innholdet $\mathrm{i}$ nr. 5.6.1 i vedlegg $\mathrm{V}$ kan endres etter framgangsmåten nevnt i artikkel 58 nr. 2 for å tilpasse det til den vitenskapelige og tekniske utvikling.

Slike ajourføringer skal ikke for noen medlemsstats vedkommende medføre noen endring av de eksisterende prinsippene i yrkeslovgivningen for utdanning og fysiske personers adgangsvilkår.

3. Farmasøytutdanningen skal være en garanti for at vedkommende har tilegnet seg følgende kunnskaper og ferdigheter:

a) tilstrekkelig kunnskap om legemidler og de stoffer som benyttes i framstilling av legemidler,

b) tilstrekkelig kunnskap om farmasøytisk teknologi og fysisk, kjemisk, biologisk og mikrobiologisk kontroll av legemidler,

c) tilstrekkelig kunnskap om stoffskiftet og virkningene av legemidler og om virkemåten til giftige stoffer samt om bruken av legemidler,

d) tilstrekkelig kunnskap til å kunne vurdere vitenskapelige data om legemidler for å kunne gi hensiktsmessige opplysninger på grunnlag av denne kunnskapen,

e) tilstrekkelig kunnskap om juridiske og andre krav i forbindelse med utøvelsen av farmasivirksomhet.

\section{Artikkel 45}

\section{Utøvelse av yrkesvirksomhet som farmasøyt}

1. I dette direktiv menes med virksomhet som farmasøyt virksomhet der adgang til og utøvelse av virksomheten $i$ en eller flere medlemsstater omfattes av vilkår for yrkeskvalifikasjoner, og som er åpen for personer som har ett av kvalifikasjonsbevisene nevnt i nr. 5.6.2 i vedlegg V.

2. Medlemsstatene skal sikre at innehavere av kvalifikasjonsbeviser i farmasi på universitetsnivå eller tilsvarende nivå, og som oppfyller bestemmelsene i artikkel 44 , skal kunne få adgang til og utøve minst følgende virksomhet, med forbehold for eventuelle krav om ytterligere yrkeserfaring:

a) galenisk framstilling av legemidler,

b) framstilling og kontroll av legemidler,

c) kontroll av legemidler i dertil egnet laboratorium,

d) lagring, oppbevaring og distribusjon av legemidler i engrosleddet, e) tillaging, kontroll, lagring og utlevering av legemidler i apotek som er åpne for allmennheten,

f) tillaging, kontroll, lagring og utlevering av legemidler på sykehus,

g) informasjon og rådgivning om legemidler.

3. Dersom en medlemsstat gjør adgang til eller utøvelse av en form for virksomhet som farmasøyt betinget av ytterligere yrkeserfaring i tillegg til besittelse av et kvalifikasjonsbevis som nevnt i nr. 5.6.2 i vedlegg V, skal medlemsstaten godkjenne som tilstrekkelig bevis $i$ så henseende en attest utstedt av vedkommende myndigheter i hjemstaten som bekrefter at personen har utøvd denne virksomheten i hjemstaten i en tilsvarende periode.

4. Godkjenningen nevnt i nr. 3 får ikke anvendelse på den toårige yrkeserfaringen som kreves i storhertugdømmet Luxembourg for tildeling av statlig konsesjon på drift av et apotek som er åpent for allmennheten.

5. Dersom det i en medlemsstat 16. september 1985 fantes et utvelgelsesprøve med det formål å velge hvem blant farmasøytene i nr. 2 som skulle bli eiere av nye apoteker, som åpnes innenfor rammen av et nasjonalt system for geografisk inndeling, kan denne medlemsstaten som unntak fra nr. 1 fortsette med denne utvelgelsesprøven og kreve at borgere i medlemsstater som har ett av kvalifikasjonsbevisene som farmasøyt som angis i nr. 5.6.2 i vedlegg $\mathrm{V}$ eller omfattes av bestemmelsene i artikkel 23, deltar i denne utvelgingen.

\section{AVSNITT 8}

\section{Arkitekt}

\section{Artikkel 46}

\section{Arkitektutdanning}

1. Arkitektutdanningen skal omfatte minst fire års studier på heltid eller seks års studier, hvorav minst tre år på heltid, ved et universitet eller tilsvarende undervisningsinstitusjon. Utdanningen skal være avsluttet med bestått eksamen på universitetsnivå.

Denne utdanningen, som skal være på universitetsnivå og der arkitektur utgjør hoveddelen, skal i like stor grad inneholde teoretiske og praktiske sider ved arkitektutdanningen og være en garanti for at kandidaten erverver følgende kunnskaper og ferdigheter:

a) evne til å utforme arkitektoniske prosjekter som oppfyller både estetiske og tekniske krav, 
b) tilstrekkelig kunnskap om arkitekturens historie og teorier samt beslektede kunstarter, teknologier og humanistiske fag,

c) kunnskap om de skjønne kunsters innflytelse på kvaliteten av arkitektonisk utforming,

d) tilstrekkelig kunnskap om byutforming og -planlegging samt den teknikk som inngår i planleggingsprosessen,

e) forståelse av forholdet mellom mennesker og bygninger og mellom bygninger og deres omgivelser, og av nødvendigheten av å tilpasse bygninger og rommet mellom dem til menneskets behov og målestokk,

f) forståelse av arkitektyrket og av arkitektens rolle i samfunnet, særlig ved utarbeidelsen av prosjekter som tar hensyn til samfunnsforhold,

g) forståelse av undersøkelses- og prosjekteringsmetoder for byggeprosjekter,

h) forståelse av struktur-, anleggs- og ingeniørmessige problemstillinger i forbindelse med bygningkonstruksjon,

i) tilstrekkelig kunnskap om fysiske problemer og teknologi og til bygningers funksjon, for å kunne utstyre dem slik at de blir behagelige å oppholde seg i og gir beskyttelse mot utendørs klima,

j) den nødvendige tekniske kompetanse til å dekke de behov brukerne av bygningen har, innenfor de rammer som settes av kostnadsfaktorer og byggeforskrifter,

k) tilstrekkelig kunnskap om de industrigrener, organisasjoner, forskrifter og framgangsmåter som inngår $\mathrm{i}$ å omsette byggeplaner til bygninger og integrere enkeltplaner i en større plansammenheng.

2. Kunnskapene og ferdighetene oppført i nr. 1 kan endres etter framgangsmåten nevnt i artikkel $58 \mathrm{nr}$. 2 med hensyn til å tilpasse dem til den vitenskapelige og tekniske utvikling.

Slike ajourføringer må ikke for noen medlemsstats vedkommende medføre noen endring av de eksisterende prinsippene i yrkeslovgivningen når det gjelder utdanning og fysiske personers adgangsvilkår.

\section{Artikkel 47}

\section{Unntak fra vilkårene for utdanning av arkitekter}

1. Som unntak fra artikkel 46 skal følgende også godkjennes som oppfyllelse av kravene i artikkel 21: den treårige utdanningen fra «Fachhochschulen» i Forbundsrepublikken Tyskland som forelå 5 . august 1985, som oppfyller kravene nevnt $\mathrm{i}$ artikkel 46 og som gir adgang til virksomheten nevnt $\mathrm{i}$ artikkel 48 i nevnte medlemsstat under yrkestittelen «arkitekt», dersom utdanningen etterfølges av fire års yrkeserfaring i Forbundsrepublikken Tyskland og bekreftes ved en attest utstedt av den yrkessammenslutningen der arkitekten som ønsker å dra fordel av bestemmelsene i dette direktiv, er registrert.

Yrkessammenslutningen skal først kontrollere at det arbeidet som den berørte arkitekten har utført på arkitekturområdet representerer en overbevisende anvendelse av kunnskapene og ferdighetene nevnt i artikkel $46 \mathrm{nr}$. 1. Attesten skal utstedes etter samme framgangsmåte som den som gjelder for registrering i yrkessammenslutningens medlemsregister.

2. Som unntak fra artikkel 46 skal følgende også godkjennes som oppfyllelse av kravene i artikkel 21: utdanning som en del av ordninger for bedring av sosial status eller universitetsstudier på deltid som oppfyller kravene nevnt i artikkel 46, bekreftet ved en eksamen $i$ arkitektur bestått av en person som har arbeidet på arkitekturområdet i minst sju år under tilsyn av en arkitekt eller et arkitektkontor. Denne eksamenen skal være på universitetsnivå og tilsvare den avsluttende eksamenen nevnt $\mathrm{i}$ artikkel 46 nr. 1 første ledd.

Artikkel 48

\section{Utøvelse av yrkesvirksomhet som arkitekt}

1. I dette direktiv menes med yrkesvirksomhet som arkitekt den virksomhet som vanligvis utføres under yrkestittelen «arkitekt».

2. Borgere i en medlemsstat som har tillatelse til å benytte denne yrkestittelen $i$ henhold til en lov som gir vedkommende myndighet $\mathrm{i}$ en medlemsstat myndighet til å gi denne tittelen til borgere i medlemsstater som spesielt har utmerket seg ved kvaliteten på sitt arbeidet på arkitekturområdet, skal anses å oppfylle de vilkår som kreves for utøvelse av yrkesvirksomhet som arkitekt under yrkestittelen «arkitekt». De berørte personenes arkitektvirksomhet skal bekreftes ved en attest utstedt av deres respektive hjemstater. 
Artikkel 49

\section{Særlige ervervede rettigheter for arkitekter}

1. Alle medlemsstater skal godta kvalifikasjonsbeviser som arkitekt nevnt i vedlegg VI, som er utstedt av de andre medlemsstatene for en utdanning som ble påbegynt senest i det akademiske referanseåret angitt $\mathrm{i}$ nevnte vedlegg, selv om de ikke oppfyller minstekravene i artikkel 46, ved å gi dem samme virkning på sine respektive territorier som de kvalifikasjonsbeviser som arkitekt som medlemsstaten selv utsteder, når det gjelder adgang til og utøvelse av yrkesvirksomhet som arkitekt.

På samme vilkår godkjennes attester utstedt av vedkommende myndigheter i Forbundsrepublikken Tyskland som bekrefter at kvalifikasjonsbeviser utstedt av vedkommende myndigheter $\mathrm{i}$ Den tyske demokratiske republikk etter 8. mai 1945, tilsvarer kvalifikasjonsbevisene angitt i nevnte vedlegg.

2. Uten at dette berører nr. 1 skal alle medlemsstater godkjenne følgende kvalifikasjonsbeviser og skal, når det gjelder adgang til og utøvelse av yrkesvirksomhet som arkitekt, gi disse kvalifikasjonsbevisene samme virkning på sine respektive territorier som kvalifikasjonsbeviser som medlemsstaten selv utsteder: attester utstedt til borgere i medlemsstater av de medlemsstatene som har vedtatt regler for adgang til og utøvelse av virksomhet som arkitekt fra og med følgende datoer:

a) 1. januar 1995 for Østerrike, Finland og Sverige,

b) 1. mai 2004 for Tsjekkia, Estland, Kypros, Latvia, Litauen, Ungarn, Malta, Polen, Slovenia og Slovakia,

c) 5. august 1987 for de andre medlemsstatene.

Attestene nevnt i nr. 1 skal bekrefte at innehaveren senest på de respektive datoene hadde tillatelse til å bruke yrkestittelen arkitekt, og at vedkommende $\mathrm{i}$ henhold til disse reglene faktisk har utøvd den berørte virksomheten i minst tre sammenhengende år i løpet av de siste fem årene før attesten ble utstedt.

\section{KAPITTEL IV}

\section{FELLES BESTEMMELSER OM ETABLERING}

\section{Artikkel 50}

\section{Dokumentasjon og formaliteter}

1. Når vedkommende myndigheter i vertsstaten har truffet en beslutning om en søknad om tillatelse til å utøve et lovregulert yrke i henhold til denne avdeling, kan de kreve de dokumenter og attester som det vises til i vedlegg VII.

Dokumentene nevnt i nr. 1 bokstav d), e) og f) i vedlegg VII skal ikke være mer enn tre måneder gamle på det tidspunkt de framlegges.

Medlemsstatene, organer og andre juridiske personer skal behandle de opplysningene de mottar fortrolig.

2. I tilfelle av begrunnet tvil kan vertsstaten kreve at vedkommende myndigheter $\mathrm{i}$ en medlemsstat bekrefter gyldigheten av de attester og kvalifikasjonsbeviser som er utstedt i denne medlemsstaten, samt eventuelt bekrefte at den begunstigede, for yrkene nevnt i kapittel III i denne avdeling, oppfyller minstekravene til utdanning fastsatt i henholdsvis artikkel 24, 25, 28, 31, 34, 35, 38, 40, 44 og 46.

3. I tilfeller av begrunnet tvil og der kvalifikasjonsbeviser som definert $\mathrm{i}$ artikkel $3 \mathrm{nr}$. 1 bokstav c) er utstedt av vedkommende myndighet $\mathrm{i}$ en medlemsstat og omfatter utdanning helt eller delvis ved en institusjon som er lovlig etablert på territoriet til en annen medlemsstat, skal vertsstaten ha rett til å undersøke følgende hos vedkommende organ i den hjemstaten der utstedelsen fant sted:

a) om utdanningsforløpet ved den berørte utdanningsinstitusjonen er formelt godkjent av utdanningsinstitusjonen i hjemstaten der utstedelsen fant sted,

b) om de utstedte kvalifikasjonsbevisene er de samme som ville vært utstedt dersom utdanningen i sin helhet hadde blitt fulgt i den hjemstaten der utstedelsen fant sted, og

c) om kvalifikasjonsbevisene gir de samme yrkesmessige rettigheter på territoriet til hjemstaten der utstedelsen fant sted.

4. Der en vertsstat krever edsavleggelse eller annen avgivelse av en høytidelig erklæring av sine borgere for å få adgang til et lovregulert yrke, og der ordlyden i nevnte ed eller erklæring ikke kan benyttes av borgere $\mathrm{i}$ andre medlemsstater, skal vertsstaten sikre at de berørte personene kan benytte en passende tilsvarende ordlyd.

Artikkel 51

\section{Framgangsmåte for gjensidig godkjenning av yrkeskvalifikasjoner}

1. Vedkommende myndighet i vertsstaten skal bekrefte mottak av søknaden innen én måned etter at den er mottatt, og informere søkeren om eventuelle manglende dokumenter. 
2. En søknad om tillatelse til å utøve et lovregulert yrke skal behandles så snart som mulig, og vedkommende myndighet i vertsstaten skal i alle tilfeller senest tre måneder etter den dato da søkerens fullstendig dokumentasjon ble oversendt, treffe en velbegrunnet beslutning. Denne fristen kan imidlertid forlenges med én måned i saker som faller inn under kapittel I og II i denne avdeling.

3. Beslutningen eller at det ikke fattes noen beslutning før fristen utløper, skal kunne påklages i henhold til nasjonal lovgivning.

\section{Artikkel 52}

\section{Bruk av yrkestitler}

1. Dersom bruken av yrkestittelen som er knyttet til en av formene for virksomhet $\mathrm{i}$ det berørte yrket er lovregulert $i$ en vertsstat, skal borgere fra de andre medlemsstatene som har tillatelse til å utøve et lovregulert yrke på grunnlag av avdeling III, benytte den yrkestittelen som i vertsstaten tilsvarer dette yrket, og bruke den eventuelle forkortelsen.

2. Dersom et yrke $i$ vertsstaten er lovregulert av en sammenslutning eller en organisasjon $i$ betydningen $i$ artikkel 3 nr. 2, kan ikke medlemsstatenes borgere bruke yrkestittelen eller forkortelsen gitt av denne organisasjonen eller sammenslutningen, med mindre de legger fram bevis på medlemskap i den berørte sammenslutningen eller organisasjonen.

Dersom sammenslutningen eller organisasjonen gjør medlemskap betinget av visse kvalifikasjoner, kan den bare gjøre dette på de vilkår som er fastsatt i dette direktiv, når det gjelder andre medlemsstaters borgere som innehar yrkeskvalifikasjoner

\section{AVDELING IV}

\section{NARMERE REGLER FOR UTØVELSE AV YRKET}

\section{Artikkel 53}

\section{Språkkunnskaper}

Personer som omfattes av godkjenning av yrkeskvalifikasjoner, skal ha de språkkunnskaper som er nødvendig for å utøve yrket i vertsstaten.

Artikkel 54

\section{Bruk av akademiske titler}

Uten at det berører artikkel 7 og 52 skal vertsstaten sikre at vedkommende personer har rett til å benytte sine akademiske titler fra hjemstaten samt eventuelle forkortelser for disse på hjemstatens språk. Vertsstaten kan kreve at tittelen etterfølges av navn og adresse til den institusjon eller eksamenskommisjon som har tildelt den. Dersom en akademisk tittel i hjemstaten antas å kunne forveksles med en tittel i vertsstaten som krever tilleggsutdanning som vedkommende person ikke har, kan vertsstaten kreve at vedkommende benytter den akademiske tittelen fra hjemstaten i en hensiktsmessig form som fastsettes av vertsstaten.

Artikkel 55

Tilknytning til sykeforsikringsordning

Uten at det berører artikkel $5 \mathrm{nr} .1$ og artikkel 6 første ledd bokstav b), skal medlemsstater som krever at personer som tilegnet seg sine yrkeskvalifikasjoner på deres territorium skal fullføre en foreberedende praktikanttid og/eller oppnå yrkeserfaring for å kunne tilknyttes en sykeforsikringsordning, frafalle denne plikten for innehavere av kvalifikasjonsbevis som lege og tannlege som er ervervet $i$ andre medlemsstater.

AVDELING V

\section{ADMINISTRATIVT SAMARBEID OG GJENNOMFØRINGSMYNDIGHET}

\section{Artikkel 56}

\section{Vedkommende myndigheter}

1. Vedkommende myndigheter i vertsstaten og i hjemstaten skal samarbeide nært og skal gi hverandre gjensidig bistand for å tilrettelegge anvendelsen av dette direktiv. De skal påse at de opplysninger som utveksles, behandles fortrolig.

2. Vedkommende myndigheter i vertsstaten og i hjemstaten skal utveksle opplysninger om disiplinære eller strafferettslige sanksjoner som vedtas, eller om andre alvorlige, særskilte omstendigheter som kan få konsekvenser for utøvelsen av virksomhet $\mathrm{i}$ henhold til dette direktiv, samtidig som det tas hensyn til lovgivningen om vern av personopplysninger fastsatt i europaparlaments- og rådsdirektiv 95/46/EF av 24. oktober 1995 om vern av fysiske personer i forbindelse med behandling av personopplysninger og om fri utveksling av slike opplysninger $\left.{ }^{1}\right)$ og i europaparlaments- og rådsdirektiv 2002/58/EF av 12. juli 2002 om behandling av personopplysninger og personvern i sektoren for elektronisk kommunikasjon (direktivet om personvern og elektronisk kommunikasjon $)\left({ }^{2}\right)$.

(1) EFT L 281 av 23.11.1995, s. 31. Direktivet endret ved forordning (EF) nr. $1882 / 2003$

(2) EFT L 201 av 31.7.2002, s. 37. 
Hjemstaten skal undersøke riktigheten av nevnte omstendigheter, og hjemstatens myndigheter skal fastsette arten og omfanget av de undersøkelser som må utføres og informere vertsstaten om de konklusjonene den trekker av de tilgjengelige opplysningene.

3. Medlemsstatene skal senest 20. oktober 2007 utpeke de myndigheter og organer som skal ha myndighet til å utstede eller motta kvalifikasjonsbeviser og andre dokumenter eller opplysninger samt de myndigheter og organer som skal ha myndighet til å motta søknader og treffe de beslutninger som er nevnt i dette direktiv, og umiddelbart underrette de øvrige medlemsstatene og Kommisjonen om dette.

4. Hver medlemsstat skal utpeke en koordinator for virksomheten til de myndigheter som er nevnt i nr. 1, og underrette de øvrige medlemsstatene og Kommisjonen om dette.

Koordinatorene har følgende oppgaver:

a) Fremme ensartet anvendelse av dette direktiv.

b) Innhente alle opplysninger som er relevante for anvendelsen av dette direktiv, særlig opplysninger om adgangsvilkår for lovregulerte yrker i medlemsstatene.

For å utføre oppgavene beskrevet under bokstav b) kan koordinatorene henvende seg til kontaktpunktene nevnt $i$ artikkel 57.

\section{Artikkel 57}

\section{Kontaktpunkter}

Hver medlemsstat skal senest 20. oktober 2007 utpeke et kontaktpunkt som skal ha følgende oppgaver:

a) Gi borgerne og kontaktpunktene i de andre medlemsstatene alle nødvendige opplysninger om godkjenning av yrkeskvalifikasjoner fastsatt i dette direktiv, særlig opplysninger om nasjonal lovgivning om yrker og yrkesutøvelse, herunder sosiallovgivning og eventuelt yrkesetiske regler.

b) Bistå borgere med å utøve de rettigheter dette direktiv gir dem, eventuelt i samarbeid med de andre kontaktpunktene og vedkommende myndigheter i vertsstaten.

På anmodning fra Kommisjonen skal kontaktpunktene underrette Kommisjonen om resultatet av de sakene de har behandlet i henhold til bokstav b) senest to måneder etter at de er mottatt.

\section{Artikkel 58}

\section{Komité for godkjenning av yrkeskvalifikasjoner}

1. Kommisjonen skal bistås av en komité for godkjenning av yrkeskvalifikasjoner, heretter kalt «komiteen», sammensatt av representanter for medlemsstatene og ledet av en representant for Kommisjonen.

2. Når det vises til dette nummer, får artikkel 5 og 7 i beslutning 1999/468/EF anvendelse, samtidig som det tas behørig hensyn til bestemmelsene i beslutningens artikkel 8 .

Tidsrommet fastsatt i artikkel $5 \mathrm{nr} .6$ i beslutning 1999/468/EF skal være to måneder.

3. Komiteen fastsetter sin forretningsorden.

$$
\text { Artikkel } 59
$$

\section{Samråd}

Kommisjonen skal sikre samråd mellom eksperter fra de berørte yrkesgruppene på en hensiktsmessig måte, særlig i forbindelse med arbeidet $\mathrm{i}$ komiteen nevnt $\mathrm{i}$ artikkel 58, og skal legge fram en begrunnet rapport om disse samrådene for nevnte komité.

\section{AVDELING VI}

\section{ANDRE BESTEMMELSER}

\section{Artikkel 60}

\section{Rapportering}

1. Fra 20. oktober 2007 skal medlemsstatene annethvert år oversende Kommisjonen en rapport om anvendelsen av ordningen. Rapporten skal i tillegg til generelle merknader inneholde en statistisk oversikt over de beslutninger som er truffet, samt en beskrivelse av de viktigste problemene som anvendelsen av dette direktiv har medført.

2. Fra 20. oktober 2007 skal Kommisjonen hvert femte år utarbeide en rapport om gjennomføringen av dette direktiv.

Artikkel 61

Unntak

Dersom en medlemsstat ved anvendelsen av en av bestemmelsene i dette direktiv, støter på større vanskeligheter på et bestemt område, skal Kommisjonen se nærmere på disse vanskelighetene i samråd med vedkommende medlemsstat.

Der det er hensiktsmessig, skal Kommisjonen treffe beslutning etter framgangsmåten nevnt i artikkel 58 nr. 2 om at vedkommende medlemsstat kan fravike den berørte bestemmelsen $\mathrm{i}$ en begrenset periode. 
Artikkel 62

\section{Oppheving}

Direktiv 77/452/EØF，77/453/EØF，78/686/EØF，78/687/ EØF, 78/1026/EØF, 78/1027/EØF, 80/154/EØF, 80/155/EØF, 85/384/EØF， 85/432/EØF，85/433/EØF，89/48/EØF，92/51/ EØF, 93/16/EØF og 1999/42/EF oppheves med virkning fra 20. oktober 2007. Henvisninger til de opphevede direktivene skal forstås som henvisninger til dette direktiv, og de rettsakter som er vedtatt på grunnlag av disse direktivene, påvirkes ikke av denne opphevingen.

$$
\text { Artikkel } 63
$$

\section{Innarbeiding i nasjonal lovgivning}

Medlemsstatene skal innen 20. oktober 2007 sette i kraft de lover og forskrifter som er nødvendige for å etterkomme dette direktiv. De skal umiddelbart underrette Kommisjonen om dette.

Disse bestemmelsene skal, når de vedtas av medlemsstatene inneholde en henvisning til dette direktiv, eller det skal vises til direktivet når de kunngjøres. Nærmere regler for henvisningen fastsettes av medlemsstatene.

Artikkel 64

\section{Ikrafttredelse}

Dette direktiv trer i kraft dagen etter at det er kunngjort i Den europeiske unions tidende.

Artikkel 65

Adressater

Dette direktiv er rettet til medlemsstatene.

Utferdiget i Strasbourg, 7. september 2005.

For Europaparlamentet

For Rådet

J. BORRELL FONTELLES

President
C. CLARKE

Formann 
VEDLEGG I

Liste over yrkessammenslutninger eller -organisasjoner som oppfyller vilkårene i artikkel 3 nr. 2

$\operatorname{IRLAND}\left({ }^{1}\right)$

1. The Institute of Chartered Accountants in $\operatorname{Ireland}\left({ }^{2}\right)$

2. The Institute of Certified Public Accountants in Ireland $\left({ }^{2}\right)$

3. The Association of Certified Accountants $\left({ }^{2}\right)$

4. Institution of Engineers of Ireland

5. Irish Planning Institute

\section{DET FORENTE KONGERIKE}

1. Institute of Chartered Accountants in England and Wales

2. Institute of Chartered Accountants of Scotland

3. Institute of Chartered Accountants in Ireland

4. Chartered Association of Certified Accountants

5. Chartered Institute of Loss Adjusters

6. Chartered Institute of Management Accountants

7. Institute of Chartered Secretaries and Administrators

8. Chartered Insurance Institute

9. Institute of Actuaries

10. Faculty of Actuaries

11. Chartered Institute of Bankers

12. Institute of Bankers in Scotland

13. Royal Institution of Chartered Surveyors

14. Royal Town Planning Institute

15. Chartered Society of Physiotherapy

16. Royal Society of Chemistry

17. British Psychological Society

18. Library Association

19. Institute of Chartered Foresters

20. Chartered Institute of Building

21. Engineering Council

22. Institute of Energy

23. Institution of Structural Engineers

24. Institution of Civil Engineers

25. Institution of Mining Engineers

${ }^{1}$ ) Irske borgere er også medlemmer av følgende sammenslutninger eller organisasjoner i Det forente kongerike: Institute of Chartered Accountants in England and Wales

Institute of Chartered Accountants of Scotland

Institute of Actuaries

Faculty of Actuaries,

The Chartered Institute of Management Accountants

Institute of Chartered Secretaries and Administrators

Royal Town Planning Institute

Royal Institution of Chartered Surveyors

Chartered Institute of Building.

(2) Bare for revisjonsvirksomhet 
26. Institution of Mining and Metallurgy

27. Institution of Electrical Engineers

28. Institution of Gas Engineers

29. Institution of Mechanical Engineers

30. Institution of Chemical Engineers

31. Institution of Production Engineers

32. Institution of Marine Engineers

33. Royal Institution of Naval Architects

34. Royal Aeronautical Society

35. Institute of Metals

36. Chartered Institution of Building Services Engineers

37. Institute of Measurement and Control

38. British Computer Society 
VEDLEGG II

Liste over utdanninger med en særlig struktur nevnt i artikkel 11 bokstav c) ii)

1. Paramedisinsk og sosialpedagogisk utdanning

Utdanning til følgende:

i Tyskland:

- pediatrisk sykepleier (Kinderkrankenschwester/Kinderkrankenpfleger),

- fysioterapeut (Krankengymnast(in)/Physiotherapeut(in))( $\left.{ }^{1}\right)$,

- ergoterapeut (Beschäftigungs- und Arbeitstherapeut/Ergotherapeut),

- logoped (Logopäde/Logopädin),

- ortoptist (Orthoptist(in)),

- offentlig godkjent barnepedagog (Staatlich anerkannte(r) Erzieher(in)),

- offentlig godkjent spesialpedagog (Staatlich anerkannte(r) Heilpädagoge(-in)),

- teknisk-medisinsk laboratorieassistent (medizinisch-technische(r) Laboratoriums- Assistent(in)),

- teknisk-medisinsk radiologassistent (medizinisch-technische(r) Radiologie-Assistent(in)),

- teknisk-medisinsk assistent innenfor funksjonsdiagnostikk (medizinisch-technische(r) Assistent(in) für Funktionsdiagnostik),

- teknisk assistent innenfor veterinærmedisin (veterinärmedizinisch-technische(r) Assistent(in)),

- dietetiker (Diätassistent(in)),

- apotektekniker (Pharmazieingenieur), oppnådd før 31. mars 1994 i den tidligere tyske demokratiske republikk eller på de nye delstatenes territorium,

- psykiatrisk sykepleier (Psychiatrische(r) Krankenschwester/Krankenpfleger),

- taleterapeut (Sprachtherapeut(in)),

som innebærer utdanning med en samlet varighet på minst 13 år, hvorav

— enten minst tre års yrkesrettet opplæring ved en fagskole, avsluttet med en eksamen, i noen tilfeller supplert med ett eller to års spesialisering avsluttet med en eksamen,

— eller minst to og et halvt år ved en fagskole avsluttet med en eksamen og i tillegg minst seks måneders yrkeserfaring eller minst seks måneders praktikanttid ved en godkjent institusjon,

— eller minst to år ved en fagskole avsluttet med en eksamen og i tillegg minst ett års yrkeserfaring eller minst ett års praktikanttid ved en godkjent institusjon.

\section{i Tsjekkia:}

- helseassistent (zdravotnický asistent),

som innebærer utdanning med en samlet varighet på minst 13 år, hvorav minst åtte års grunnutdanning og fire års yrkesrettet videregående opplæring med helsefaglig studieretning, avsluttet med eksamenen «maturitní zkouška»,

- ernæringsassistent (nutrièní asistent),

som innebærer utdanning med en samlet varighet på minst 13 år, hvorav minst åtte års grunnutdanning og fire års yrkesrettet videregående opplæring med helsefaglig studieretning, avsluttet med eksamenen «maturitní zkouška»,

i Italia:

- tanntekniker (odontotecnico)

- optiker (ottico)

(1) Fra og med 1. juni 1994 ble yrkestittelen «Krankengymnast(in)» erstattet med «Physiotherapeut(in)». Medlemmer av dette yrket som fikk sine diplomer før denne dato, kan likevel, dersom de ønsker det, fortsatt benytte den tidligere tittelen «Krankengymnast(in)». 
som innebærer utdanning med en samlet varighet på minst 13 år, hvorav

- $\quad$ enten minst tre års yrkesrettet opplæring ved en fagskole, avsluttet med en eksamen, i noen tilfeller supplert med ett eller to års spesialisering avsluttet med en eksamen,

- eller minst to og et halvt år ved en fagskole avsluttet med en eksamen og i tillegg minst seks måneders yrkeserfaring eller minst seks måneders praktikanttid ved en godkjent institusjon,

- $\quad$ eller minst to år ved en fagskole avsluttet med en eksamen og i tillegg minst ett års yrkeserfaring eller minst ett års praktikanttid ved en godkjent institusjon.

Kypros:

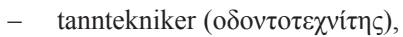

som innebærer utdanning med en samlet varighet på minst 14 år, hvorav minst seks års grunnutdanning, seks års videregående opplæring og to års yrkesrettet høyere utdanning, etterfulgt av ett års yrkeserfaring,

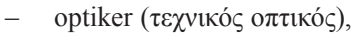

som innebærer utdanning med en samlet varighet på minst 14 år, hvorav minst seks års grunnutdanning, seks års videregående opplæring og to års høyere utdanning, etterfulgt av ett års yrkeserfaring,

i Latvia:

- tannpleier (zobārstniecības māsa),

som innebærer utdanning med en samlet varighet på minst 13 år, hvorav minst ti års grunnutdanning og to års yrkesrettet opplæring ved et lærested for helsefaglig utdanning, etterfulgt av tre års yrkeserfaring, som avsluttes med en bestått eksamen for å oppnå en attest på denne spesialistutdanningen,

- biomedisinsk laboratorieassistent (biomedicīnas laborants),

som innebærer utdanning med en samlet varighet på minst tolv år, hvorav minst ti års grunnutdanning og to års yrkesrettet opplæring ved et lærested for helsefag, etterfulgt av to års yrkeserfaring, som avsluttes med en bestått eksamen for å oppnå en attest på denne spesialistutdanningen,

- tanntekniker (zobu tehniksis),

som innebærer utdanning med en samlet varighet på minst tolv år, hvorav minst ti års grunnutdanning og to års yrkesrettet opplæring ved et lærested for helsefag, etterfulgt av to års yrkeserfaring, som avsluttes med en bestått eksamen for å oppnå en attest på denne spesialistutdanningen,

- fysioterapeutassistent (fizioterapeita asistents),

som innebærer en utdanning med en samlet varighet på minst 13 år, hvorav minst ti års grunnutdanning og to års yrkesrettet opplæring ved et lærested for helsefag, etterfulgt av to års yrkeserfaring, som avsluttes med en bestått eksamen for å oppnå en attest på denne spesialistutdanningen,

i Luxembourg:

- teknisk radiologassistent (assistant(e) technique médical(e) en radiologie),

- teknisk-medisinsk laboratorieassistent (assistant(e) technique médical(e) de laboratoire),

- $\quad$ psykiatrisk sykepleier (infirmier/ière psychiatrique),

- teknisk-medisinsk assistent (kirurgi) (assistant(e) technique medical(e) en chirurgie),

- pediatrisk sykepleier (infirmier/ière puériculteur(trice)),

- anestesisykepleier (infirmier/ière anesthésiste),

- massør med godkjent utdanning (masseur/euse diplômé(e)),

- barnepedagog (éducateur/trice),

som innebærer utdanning med en samlet varighet på minst 13 år, hvorav

- enten minst tre års yrkesrettet opplæring ved en fagskole, avsluttet med en eksamen, i noen tilfeller supplert med ett eller to års spesialisering avsluttet med en eksamen,

- eller minst to og et halvt år ved en fagskole avsluttet med en eksamen og i tillegg minst seks måneders yrkeserfaring eller minst seks måneders praktikanttid ved en godkjent institusjon,

- eller minst to år ved en fagskole avsluttet med en eksamen og i tillegg minst ett års yrkeserfaring eller minst ett års praktikanttid ved en godkjent institusjon.

i Nederland,

- veterinærassistent (dierenartsassistent), 
som innebærer utdanning med en samlet varighet på minst 13 år, hvorav tre års yrkesrettet opplæring på en fagskole (MBO-ordningen) eller tre års yrkesrettet opplæring i den kombinerte lærlingordningen (LLW), som begge avsluttes med en eksamen.

i Østerrike:

- særlig grunnutdanning i pediatrisk sykepleie (spezielle Grundausbildung in der Kinder- und Jugendlichenpflege),

- særlig grunnutdanning i psykiatrisk sykepleie (spezielle Grundausbildung in der psychiatrischen Gesundheitsund Krankenpflege),

- kontaktlinseoptiker (Kontaktlinsenoptiker),

- fotpleier (Fußpfleger),

- høreapparatmaker (Hörgeräteakustiker),

- forhandler av apotekervarer (Drogist),

som innebærer utdanning med en samlet varighet på minst 14 år, hvorav minst fem år innenfor en strukturert utdanningsordning, som består av en læretid på minst tre år som omfatter opplæring delvis på en arbeidsplass og delvis ved en fagskole samt en periode med yrkespraksis og -opplæring, som avsluttes med en yrkeseksamen som gir rett til å utøve yrket og utdanne lærlinger,

- massør (Masseur),

som innebærer utdanning med en samlet varighet på 14 år, hvorav minst fem år innenfor en strukturert utdanningsordning som omfatter en læretid på to år, en periode med yrkespraksis og -opplæring på to år samt en opplæringsperiode på ett år som avsluttes med en yrkeseksamen som gir rett til å utøve yrket og utdanne lærlinger,

- førskolelærer (Kindergärtner/in),

- barnepedagog (Erzieher),

som innebærer utdanning med en samlet varighet på 13 år, herunder fem års yrkesrettet opplæring ved en fagskole, som avsluttes med en eksamen,

i Slovakia:

- lærer i dans ved skoler for grunnleggende kunstutdanning (učitel' v tanečnom odbore na základných umeleckých školách),

som innebærer utdanning med en samlet varighet på minst 14,5 år, hvorav åtte års grunnutdanning, fire års studier ved en videregående skole med særskilt studieretning og et kurs i dansepedagogikk på fem semestre,

- lærer ved særlige utdanningsinstitusjoner og ved sosialtjenesteinstitusjoner (vychovávatel’ v špeciálnych výchovných zariadeniach a v zariadeniach sociálnych služieb),

som innebærer utdanning med en samlet varighet på minst 14 år, hvorav åtte eller ni års grunnutdanning, fire års studier ved en videregående skole med pedagogisk studieretning eller ved en annen videregående skole og to års tilleggsstudier i pedagogikk på deltid. 
2. Håndverksmesterutdanning (Mester/Meister/Maître) som innebcerer utdanning innenfor håndverksvirksomhet som ikke omfattes av dette direktivs avdeling III kapittel II.

Utdanning til følgende:

i Danmark:

- optiker (optometrist),

med en samlet utdanningstid på 14 år, hvorav fem års yrkesrettet opplæring fordelt på to og et halvt år med teoretisk utdanning ved et lærested for yrkesrettet opplæring og to og et halvt år med praktisk utdanning på en arbeidsplass, avsluttet med en bestått eksamen i håndverksfaget, som gir rett til tittelen "Mester",

- ortopeditekniker (ortopædimekaniker),

med en samlet utdanningstid på 12,5 år, hvorav tre og et halvt års yrkesrettet opplæring fordelt på seks måneder med teoretisk utdanning ved et lærested for yrkesrettet opplæring og tre år med praktisk utdanning på en arbeidsplass, avsluttet med en bestått eksamen i håndverksfaget, som gir rett til tittelen «Mester»,

- ortopediskomaker (ortopædiskomager),

med en samlet utdanningstid på 13,5 år, hvorav fire og et halvt års yrkesrettet opplæring fordelt på to år med teoretisk utdanning ved et lærested for yrkesrettet opplæring og to og et halvt år med praktisk utdanning på en arbeidsplass, avsluttet med en bestått eksamen i håndverksfaget, som gir rett til tittelen «Mester»,

i Tyskland:

- optiker (Augenoptiker),

- tanntekniker (Zahntechniker),

- bandasjist (Bandagist),

- høreapparatmaker (Hörgeräte-Akustiker),

- ortopeditekniker (Orhtopädiemechaniker),

- ortopediskomaker (Orthopädieschuhmacher),

i Luxembourg:

- optiker (opticien),

- tanntekniker (mécanicien dentaire),

- høreapparatmaker (audioprothésiste),

- ortopeditekniker/bandasjist (mecanicien orthopédiste/bandagiste),

- ortopediskomaker (orthopédiste-cordonnier),

med en samlet utdanningstid på 14 år, hvorav minst fem års utdanning innenfor en strukturert utdanningsordning, delvis ervervet på en arbeidsplass og delvis ved et lærested for yrkesrettet opplæring, og avsluttet med en eksamen som må bestås for å kunne praktisere et håndverksfag enten som selvstendig næringsdrivende eller som lønnsmottaker med et tilsvarende ansvarsnivå,

i Østerrike:

- bandasjist (Bandagist),

- korsettmaker (Miederwarenerzeuger), 
- optiker (Optiker),

- ortopediskomaker (Orthopädieschuhmacher),

- ortopeditekniker (Orthopädietechniker),

- tanntekniker (Zahntechniker),

- gartner (Gärtner)

som innebærer utdanning med en samlet varighet på minst 14 år, hvorav minst fem år innenfor en strukturert utdanningsordning, fordelt på en læretid på minst tre år delvis på en arbeidsplass og delvis ved et lærested for yrkesrettet opplæring, og en periode på to år med yrkespraksis og -opplæring, avsluttet med en mesterprøve som gir rett til å utøve yrket, undervise lærlinger og bruke tittelen «Meister»,

håndverksmesterutdanning innenfor jord- og skogbruk, dvs.

- mester i landbruksfag (Meister in der Landwirtschaft),

- mester i landbruksøkonomi (Meister in der ländlichen Hauswirtschaft),

- mester i hagebruk (Meister im Gartenbau),

- mester i kommersielt hagebruk (Meister im Feldgemüsebau),

- mester i fruktdyrking og -behandling (Meister im Obstbau und in der Obstverwertung),

- mester i vindyrking og vinframstilling (Meister im Weinbau und in der Kellerwirtschaft),

- mester i meieribruk (Meister in der Molkerei- und Käsereiwirtschaft),

- mester i hestehold (Meister in der Pferdewirtschaft),

- mester i fiskeri (Meister in der Fischereiwirtschaft),

- mester i fjørfeavl (Meister in der Geflügelwirtschaft),

- mester i biavl (Meister in der Bienenwirtschaft),

- mester i skogbruk (Meister in der Forstwirtschaft),

- mester i skogplanting og skogforvaltning (Meister in der Forstgarten- und Forstpflegewirtschaft),

- mester i lagring av landbruksprodukter (Meister in der landwirtschaftlichen Lagerhaltung),

som innebærer utdanning med en samlet varighet på minst 15 år, hvorav minst seks år innenfor en strukturert utdanningsordning, fordelt på en læretid på minst tre år delvis på en arbeidsplass og delvis ved et lærested for yrkesrettet opplæring, og en periode på tre år med yrkespraksis, avsluttet med en mesterprøve i det berørte yrket som gir rett til å undervise lærlinger og bruke tittelen «Meister»,

i Polen:

- lærer innenfor praktisk yrkesrettet opplæring (Nauczyciel praktycznej nauki zawodu),

som innebærer utdanning med en varighet på

i) åtte år med grunnutdanning og fem år med yrkesrettet videregående opplæring eller tilsvarende videregående opplæring på et relevant område, etterfulgt av et kurs i pedagogikk på minst 150 timer, kurs i sikkerhet og hygiene på arbeidsplassen samt to års yrkeserfaring i det yrket som vedkommende skal undervise i, eller

ii) åtte år med grunnutdanning og fem år med yrkesrettet videregående opplæring samt avgangsdiplom fra en fagskole for høyere pedagogisk utdanning, eller 
iii) åtte år med grunnutdanning og to til tre år med grunnleggende yrkesrettet videregående opplæring og minst tre års yrkeserfaring, bekreftet ved en mesterprøve i det berørte yrket etterfulgt av et kurs i pedagogikk på minst 150 timer,

i Slovakia:

- lærer innenfor yrkesrettet opplæring (majster odbornej výchovy),

som innebærer utdanning med en samlet varighet på minst tolv år, hvorav åtte års grunnutdanning, fire års yrkesrettet opplæring (fullført yrkesrettet videregående opplæring og/eller læretid i relevant (tilsvarende) yrkesrettet opplæring eller et lærlingkurs), yrkeserfaring med en samlet varighet på minst tre år innenfor området for den fullførte utdanningen eller læretiden samt tilleggsstudier i pedagogikk ved et pedagogisk fakultet eller ved en teknisk høyskole, eller fullført videregående opplæring og læretid i relevant (tilsvarende) yrkesrettet opplæring eller lærlingkurs, yrkeserfaring med en samlet varighet på minst tre år på området for den fullførte utdanningen eller læretiden samt tilleggsstudier i pedagogikk ved et pedagogisk fakultet eller, innen 1. september 2005, spesialutdanning innenfor området spesialpedagogikk som gis ved metodesentre for lærere innenfor yrkesrettet opplæring ved spesialskoler uten tilleggsstudier i pedagogikk.

3. Sjøfartssektoren

a) Sjøtransport

Utdanning til følgende:

i Tsjekkia:

- dekksmatros (palubní asistent),

- befal med ansvar for brovakt (námořní poručík),

- overstyrmann (první palubní důstojník),

- $\quad$ kaptein (kapitán),

- maskinassistent (strojní asistent),

- befal med ansvar for maskinvakt (strojní důstojník),

- førstemaskinist (druhý strojní důstojník),

- maskinsjef (první strojní důstojník),

- elektriker (elektrotechnik),

- sjefselektriker (elektrodůstojník);

i Danmark:

- skipsfører (skibsfører),

- førstestyrmann (overstyrmand),

- kvartermester, vakthavende styrmann (enestyrmand, vagthavende styrmand),

- vakthavende styrmann (vagthavende styrmann),

- maskinsjef (maskinchef),

- førstemaskinist (1. maskinmester),

- førstemaskinist/vakthavende maskinist (1. maskinmester/vagthavende maskinmester).

i Tyskland:

- kaptein, stort kystfartøy (Kapitän AM),

- $\quad$ kaptein, kystfartøy (Kapitän AK),

- styrmann, stort kystfartøy (Nautischer Schiffsoffizier AMW), 
- styrmann, kystfartøy (Nautischer Schiffsoffizier AKW),

- $\quad$ maskinsjef, grad C (Schiffsbetriebstechniker CT - Leiter von Maschinenanlagen),

- førstemaskinist, grad C (Schiffsmaschinist CMa - Leiter von Maschinenanlagen),

- maskinist, grad C (Schiffsbetriebstechniker CTW),

- førstemaskinist, grad C - eneste maskinoffiser (Schiffsmaschinist CMaW - Technischer Alleinoffizier).

i Italia:

- styrmann (ufficiale di coperta),

- maskinist (ufficiale di macchina),

i Latvia:

- skipselektrisk maskinoffiser (kuǵu elektromehāniķis),

- operatør av kjølemaskineri (kuğa saldēšanas iekārtu mašīnists);

- i Nederland:

- førstestyrmann (kystfartøy) (med tilleggsutdanning) (stuurman kleine handelsvaart (met aanvulling)),

- maskinist på kystfartøy (med diplom) (diploma motordrijver),

- VTS-tjenestemann (VTS-functionaris),

- som innebærer følgende utdanning:

i Tsjekkia:

i) for dekksmatros (palubní asistent),

1. en person som er minst 20 år,

2. a) sjøfartsakademi eller -skole — avdeling for navigasjon, begge kurs må avsluttes med eksamenen «maturitní zkouška», samt godkjent fartstid på minst seks måneder i løpet av studiene, eller

b) godkjent fartstid på minst to år som mannskap, der vedkommende har deltatt i brovakt på støttenivå på skip, og fullført et godkjent kurs som oppfyller den kompetansestandard som er angitt $\mathrm{i}$ avdeling A-II/1 i STCW-regelverket (IMOs internasjonale konvensjon om normer for opplæring, sertifikater og vakthold for sjøfolk) gitt av et sjøfartsakademi eller en sjøfartsskole hos en part i STCWkonvensjonen samt bestått eksamen for eksamenskommisjonen godkjent av MTC (Tsjekkias komité for sjøtransport),

ii) for befal med ansvar for brovakt (námořní poručík),

1. godkjent fartstid i stilling som dekksmatros på skip på 500 brutto registertonn eller mer i minst seks måneder når det gjelder en avgangselev fra en sjøfartsskole eller et sjøfartsakademi, eller ett år når det gjelder en avgangselev fra et godkjent kurs, hvorav minst seks måneder som mannskap som utgjør en del av en brovakt,

2. behørig utfylt og godkjent opplæringsjournal for dekkskadetter,

iii) for overstyrmann (první palubní důstojník),

kompetansebevis som befal med ansvar for brovakt på skip på 500 brutto registertonn eller mer og minst 12 måneders godkjent fartstid i denne stillingen, 
iv) for kaptein (kapitán),

$=$ attest for tjeneste som skipsfører på skip mellom 500 og 3000 brutto registertonn

$=$ kompetansebevis som overstyrmann på skip på 3000 brutto registertonn eller mer og minst seks måneder godkjent fartstid som overstyrmann på skip på 500 brutto registertonn eller mer samt minst seks måneders godkjent fartstid som overstyrmann på skip på 3000 brutto registertonn eller mer,

v) for maskinassistent (strojní asistent),

1. en person som er minst 20 år,

2. sjøfartsakademi eller sjøfartsskole — avdeling for skipsingeniører samt godkjent fartstid på minst seks måneder i løpet av studiene,

vi) for befal med ansvar for maskinvakt (strojní důstojník),

godkjent fartstid på minst seks måneder som maskinassistent som avgangselev fra et sjøfartsakademi eller en sjøfartsskole,

vii) for førstemaskinist (druhý strojní důstojník),

godkjent fartstid på minst 12 måneder som tredjemaskinist på skip drevet av et hovedmaskineri med framdriftskraft på minst $750 \mathrm{~kW}$,

viii) for maskinsjef (první strojní důstojník),

relevant attest for tjeneste som førstemaskinist på skip drevet av et hovedmaskineri med framdriftskraft på minst $3000 \mathrm{~kW}$ og som har minst seks måneders godkjent fartstid i denne stillingen,

ix) for elektriker (elektrotechnik),

1. en person som er minst 18 år,

2. sjøfartsakademi eller annet akademi, fakultet for elektroteknikk eller teknisk skole eller høyskole for elektroteknikk, der alle kurs skal være avsluttet med eksamenen «maturitní zkouška» og minst 12 måneders godkjent praksis på området elektroteknologi,

x) for sjefselektriker (elektrodůstojník);

1. sjøfartsakademi eller annet akademi, fakultet for skipselektroteknikk, eller annet akademi eller en videregående skole med studieretningen elektroteknikk, der alle kurs skal være avsluttet med eksamenen «maturitní zkouška» eller en statlig eksamen,

2. godkjent fartstid som elektriker i en periode på minst 12 måneder for avgangselever fra et akademi eller en høyskole, eller 24 måneder for avgangselever fra en videregående skole,

- i Danmark:

ni års grunnskole etterfulgt av 17 til 36 måneders grunnleggende yrkesrettet opplæring og/eller fartstid, supplert med

i) for vakthavende styrmann, ett års spesialisert yrkesrettet opplæring,

ii) for andre, tre års spesialisert yrkesrettet opplæring,

- i Tyskland:

utdanning med en samlet varighet på mellom 14 og 18 år, hvorav tre års grunnleggende yrkesrettet opplæring og ett års fartstid, etterfulgt av ett eller to års spesialisert yrkesrettet opplæring, eventuelt supplert med to års yrkeserfaring fra sjøfart, 
i) for skipselektrisk maskinoffiser (kuǵu elektromehāniķis),

1. en person som er minst 18 år,

2. som innebærer utdanning med samlet varighet på minst tolv og et halvt år, hvorav av minst ni års grunnutdanning og minst tre års yrkesrettet opplæring. I tillegg kreves fartstid på minst seks måneder som skipselektriker eller som assistent for elektroingeniør på skip med større generatorkraft enn $750 \mathrm{~kW}$. Yrkesrettet opplæring avsluttes med en særlig eksamen avlagt ved vedkommende myndighet i samsvar med opplæringsprogrammet godkjent av transportdepartementet,

ii) for operatør av kjølemaskineri (kuğa saldēšanas iekārtu mašñnists),

1. en person som er minst 18 år,

2. som innebærer utdanning med samlet varighet på minst 13 år, hvorav av minst ni års grunnutdanning og minst tre års yrkesrettet opplæring. I tillegg kreves fartstid på minst 12 måneder som assistent for kjøleingeniør. Yrkesrettet opplæring avsluttes med en særlig eksamen avlagt ved vedkommende myndighet i samsvar med opplæringsprogrammet godkjent av transportdepartementet,

- i Italia:

utdanning med en samlet varighet på 13 år, hvorav minst fem års yrkesrettet opplæring avsluttet med en eksamen, eventuelt supplert med et praksisopphold,

- i Nederland:

i) for førstestyrmann (kystfartøy) (med tilleggsutdanning) (stuurman kleine handelsvaart (met aanvulling)) og maskinist på kystfartøy (med diplom) (diploma motordrijver), med 14 års utdanning, hvorav minst to år ved et spesialisert lærested for yrkesrettet opplæring, avsluttet med et 12 måneders praksisopphold,

ii) for VTS-tjenestemann (VTS-functionaris), en samlet utdanning på minst 15 år, hvorav minst tre års høyere yrkesrettet opplæring («HBO») eller yrkesrettet opplæring på mellomnivå («MBO»), som etterfølges av nasjonale og regionale spesialiseringskurs, som hvert består av minst 12 ukers teoretisk opplæring og avsluttes med en eksamen,

og som er godkjent i henhold til den internasjonale STCW-konvensjonen (Den internasjonale konvensjon om normer for opplæring, sertifikater og vakthold for sjøfolk, 1978).

b) Havfiske

Utdanning til følgende:

i Tyskland:

- kaptein, dyphavsfiske (Kapitän BG/Fischerei),

- $\quad$ kaptein, kystfiske (Kapitän BLK/Fischerei),

- styrmann, dyphavsfiskefartøy (Nautischer Schiffsoffizier BGW/Fischerei),

- styrmann, kystfiskefartøy (Nautischer Schiffsoffizier BK/Fischerei),

i Nederland:

- førstestyrmann/maskinist V (stuurman werktuigkundige V),

- maskinist IV (fiskefartøy) (werktuigkundige IV visvaart),

- førstestyrmann IV (fiskefartøy) (stuurman IV visvaart),

- førstestyrmann/maskinist VI (stuurman werktuigkundig VI), 
som innebærer følgende utdanning:

- $\quad$ i Tyskland, utdanning med en samlet varighet på mellom 14 og 18 år, hvorav tre års grunnleggende yrkesrettet opplæring og ett års fartstid, etterfulgt av ett eller to års spesialisert yrkesrettet opplæring, eventuelt supplert med to års yrkeserfaring fra navigasjon,

- i Nederland, utdanning av varierende varighet mellom 13 og 15 år, hvorav minst to år ved en spesialisert fagskole, supplert med 12 måneders yrkeserfaring,

og som er godkjent i henhold til Torremolinos-konvensjonen (Den internasjonale konvensjon om fiskefartøyers sikkerhet, 1977).

4. Tekniske yrker

Utdanning til følgende:

i Tsjekkia:

- autorisert tekniker, autorisert byggmester (autorizovaný technik, autorizovaný stavitel),

som innebærer yrkesrettet opplæring med en varighet på minst ni år, hvorav fire år på en teknisk videregående skole, fullført med eksamenen «maturitní zkouška» og fem års yrkeserfaring, avsluttet med en prøve i yrkeskvalifikasjoner for å kunne utøve den valgte yrkesvirksomheten innenfor byggfag (i henhold til lov nr. 50/1976 Sb. (bygningsloven) og lov nr. 360/1992 Sb.),

- fører av rullende materiell (fyzická osoba řídící drážní vozidlo),

som innebærer en utdanning med en samlet varighet på minst tolv år, hvorav minst åtte års grunnutdanning og minst fire års yrkesrettet videregående opplæring avsluttet med eksamenen «maturitní zkouška» og avsluttet med statseksamen i rullende materiells framdrift,

- $\quad$ sporkontrolltekniker (drážní revizní technik),

som innebærer en utdanning med en samlet varighet på minst tolv år, hvorav minst åtte års grunnutdanning og minst fire års yrkesrettet videregående opplæring i maskin- eller elektrofag og avsluttet med eksamenen «maturitni zkouška»,

- $\quad$ kjørelærer (učitel autođkoly)

en person som er minst 24 år, utdanning med en samlet varighet på minst tolv år, hvorav minst åtte års grunnutdanning og minst fire års yrkesrettet videregående opplæring med fokus på trafikk eller motor og avsluttet med eksamenen «maturitní zkouška»,

- offentlig godkjent tekniker for meldt av motorvogner (kontrolní technik STK),

en person som er minst 21 år, utdanning med en samlet varighet på minst tolv år, hvorav minst åtte års grunnutdanning og minst fire års yrkesrettet videregående opplæring som avsluttes med eksamenen «maturitní zkouška», etterfulgt av minst to års teknisk praksis. Den berørte personen må ha førerkort, rent rulleblad og ha fullført spesialopplæringen på minst 120 timer for offentlig godkjente teknikere samt bestått eksamen,

- mekaniker for kontroll av utslipp fra biler (mechanik měření emisí),

som innebærer en utdanning med en samlet varighet på minst tolv år, hvorav minst åtte års grunnutdanning og minst fire års yrkesrettet videregående opplæring avsluttet med eksamenen «maturitní zkouška». Videre må søkeren fullføre minst tre års teknisk praksis og spesialopplæringen for «mekaniker for kontroll av utslipp fra biler» med en varighet på åtte timer samt ha bestått eksamen,

- $\quad$ skipsfører klasse I (kapitán I. tř́ídy),

som innebærer en utdanning med en samlet varighet på minst 15 år, hvorav minst åtte års grunnutdanning og tre års yrkesrettet opplæring avsluttet med eksamenen «maturitní zkouška» og fullført med en eksamen bekreftet ved en egnethetsattest. Denne yrkesrettede opplæringen skal etterfølges av fire års yrkeserfaring avsluttet med en eksamen, 
- restauratør av minnesmerker som er å betrakte som kunsthåndverk (restaurátor památek, které jsou díly uměleckých řemesel),

som innebærer en utdanning med en samlet varighet på tolv år dersom den omfatter full teknisk videregående opplæring i restaurering, eller ti til tolv års studier i et tilknyttet emne, pluss fem års yrkeserfaring i tilfelle av full teknisk videregående opplæring avsluttet med eksamenen «maturitní zkouška», eller åtte års yrkeserfaring i tilfelle av teknisk videregående opplæring avsluttet med lærlingeksamen,

- restauratør av kunstverk som ikke er å betrakte som minnesmerker og som oppbevares i samlinger i museer og gallerier, og av andre gjenstander av kulturell verdi (restaurátor děl výtvarných umění, která nejsou památkami a jsou uložena ve sbírkách muzeí a galerií, a ostatních předmětů kulturní hodnoty),

som innebærer en utdanning med en samlet varighet på tolv år, pluss fem års yrkeserfaring i tilfelle av full teknisk videregående opplæring i restaurering og avsluttet med eksamenen «maturitní zkouška»,

- avfallshåndterer (odpadový hospodáŕ),

som innebærer en utdanning med en samlet varighet på minst tolv år, hvorav minst åtte års grunnutdanning og minst fire års yrkesrettet videregående opplæring, avsluttet med eksamenen «maturitní zkouška», og minst fem års erfaring innenfor avfallshåndteringssektoren i løpet av de siste ti årene,

- $\quad$ sprengningsteknisk leder (technický vedoucí odstřelů),

som innebærer en utdanning med en samlet varighet på minst tolv år, hvorav minst åtte års grunnutdanning og minst fire års yrkesrettet videregående opplæring avsluttet med eksamenen «maturitní zkouška»,

og etterfulgt av

to år som sprenger under jorden (for virksomhet under jorden) eller ett år over jorden (for virksomhet over jorden), herunder seks måneder som assisterende sprenger,

opplæringskurs på 100 timer med teoretisk og praktisk opplæring etterfulgt av en eksamen avlagt ved en relevant gruvedistriktsmyndighet,

yrkeserfaring på seks måneder eller mer innenfor planlegging og utføring av større sprengningsarbeider,

opplæringskurs på 32 timer med teoretisk og praktisk opplæring etterfulgt av en eksamen avlagt ved den tsjekkiske gruvemyndigheten,

i Italia:

- landmåler (geometra),

- landbrukstekniker (perito agrario),

som innebærer teknisk videregående opplæring med en varighet på minst 13 år, hvorav åtte års grunnskole etterfulgt av fem års videregående opplæring, herunder tre års yrkesrettet opplæring avsluttet med en teknisk baccalaureat-eksamen, og supplert

i) for landmåler (geometra), enten med et praksisopphold på minst to år i en relevant virksomhet, eller fem års yrkeserfaring,

ii) for landbrukstekniker (perito agrario), med et gjennomført praksisopphold på minst to år,

etterfulgt av en statlig eksamen,

i Latvia:

- lokomotivførerassistent (vilces līdzekḷa vadītāja (mašīnista) palīgs),

en person som er minst 18 år; innebærer utdanning med en samlet varighet på minst tolv år, hvorav minst åtte års grunnutdanning og minst fire års yrkesrettet opplæring. Den yrkesrettede opplæringen avsluttes med en særlig eksamen som arbeidsgiver arrangerer. Kompetansebevis utstedes av vedkommende myndighet for fem år, 


\section{i Nederland:}

- namsmann (gerechtsdeurwaarder),

- tannprotesemaker (tandprotheticus),

som innebærer studier og yrkesrettet opplæring

i) når det gjelder namsmann (gerechtsdeurwaarder), en samlet utdanning på 19 år, hvorav åtte års grunnskole etterfulgt av åtte års videregående skole, herunder fire års teknisk utdanning, avsluttet med en offentlig eksamen og supplert med tre års teoretisk og praktisk yrkesrettet opplæring,

ii) når det gjelder tannprotesemaker (tandprotheticus), en samlet utdanning på minst 15 år på heltid og i tillegg tre år på deltid, hvorav åtte års grunnskole etterfulgt av åtte års allmenn videregående opplæring, fullført tre års yrkesrettet opplæring, som inneholder teoretisk og praktisk opplæring som tanntekniker, supplert med tre års deltidsutdanning som tannprotesemaker, og avsluttet med en eksamen,

i Østerrike:

- forstmann (Förster),

- teknisk konsulent (Technisches Büro),

- utleier av arbeidskraft (Überlassung von Arbeitskräften - Arbeitsleihe),

- arbeidsformidler (Arbeitsvermittlung),

- investeringsrådgiver (Vermögensberater),

- privatetterforsker (Berufsdetektiv),

- sikkerhetsvakt (Bewachungsgewerbe),

- eiendomsmegler (Immobilienmakler),

- eiendomsforvalter (Immobilienverwalter),

- byggprosjektleder (Bauträger, Bauorganisator, Baubetreuer),

- inkassobyrå (Inkassobüro/Inkassoinstitut),

som innebærer utdanning med en samlet varighet på minst 15 år, hvorav åtte års grunnskole etterfulgt av minst fem års teknisk eller økonomisk videregående opplæring, avsluttet med en teknisk eller økonomisk eksamen, supplert med minst to års utdanning og opplæring på en arbeidsplass og avsluttet med en yrkeseksamen,

- forsikringskonsulent (Berater in Versicherungsangelegenheiten),

som innebærer utdanning med en samlet varighet på 15 år, hvorav seks år innenfor en strukturert utdanningsordning, fordelt på en læretid på tre år og tre års yrkespraksis og -opplæring, avsluttet med en eksamen,

- byggmester/planlegging og teknisk beregning (Planender Baumeister),

- tømrermester/planlegging og teknisk beregning (Planender Zimmermeister),

som innebærer utdanning med en samlet varighet på minst 18 år, herunder minst ni års yrkesrettet opplæring fordelt på fire års teknisk videregående opplæring og fem års yrkespraksis og yrkesopplæring, avsluttet med en yrkeseksamen som gir rett til å utøve yrket og undervise lærlinger i å planlegge bygninger, foreta tekniske beregninger og føre tilsyn med bygningsarbeidet (det såkalte Maria Theresia-privilegiet),

- regnskapsfører (Gewerblicher Buchhalter), i henhold til «Gewerbeordnung» av 1994 (lov av 1994 om handel, håndverk og industri),

- selvstendig regnskapsfører (Selbständiger Buchhalter), i henhold til «Bundesgesetz über die Wirtschaftstreuhandberufe» av 1999 (lov av 1999 om yrker innenfor offentlig revisjon), 
i Polen:

- offentlig tekniker som utfører grunnleggende meldt av motorvogner på en kontrollstasjon (diagnosta przeprowadzajàcy badania techniczne w stacji kontroli pojazdów o podstawowym zakresie badañ),

som innebærer åtte års grunnutdanning og fem års yrkesrettet videregående opplæring i bilfag og tre års praksis på en servicestasjon for motorvogner eller på et verksted, som omfatter 51 timer med grunnleggende opplæring $\mathrm{i}$ meldt av motorvogner og bestått kvalifikasjonseksamen,

- tekniker som utfører meldt av motorvogner på en distriktskontrollstasjon (diagnosta przeprowadzajàcy badania techniczne pojazdu w okrægowej stacji kontroli pojazdów),

som innebærer åtte års grunnutdanning og fem års yrkesrettet videregående opplæring i bilfag og fire års praksis på en servicestasjon for motorvogner eller på et verksted, som omfatter 51 timer med grunnleggende opplæring 1 meldt av motorvogner og bestått kvalifikasjonseksamen,

- tekniker som utfører meldt av motorvogner på en kontrollstasjon (diagnosta wykonujący badania techniczne pojazdów w stacji kontroli pojazdów),

som innebærer

i) åtte års grunnutdanning og fem års yrkesrettet videregående opplæring i bilfag og fire års dokumentert praksis på en servicestasjon for motorvogner eller på et verksted, eller

ii) åtte års grunnutdanning og fem års yrkesrettet videregående opplæring på et annet felt enn bilfag samt åtte års dokumentert praksis på en servicestasjon for motorvogner eller på et verksted, som omfatter til sammen 113 timer med fullstendig opplæring, herunder grunn- og spesialopplæring, med eksamener etter hvert trinn,

Varigheten i timer og det generelle omfanget av de enkelte kursene innenfor rammen av den fullstendige opplæringen for denne typen teknikere angis særskilt i infrastrukturdepartementets forordning av 28. november 2002 om detaljerte krav som gjelder teknikere (EFT 2002, nr. 208, pos. 1769),

- togleder (dyżurny ruchu),

som innebærer åtte års grunnutdanning og fire års yrkesrettet videregående opplæring, med jernbanetransport som spesialisering, samt et kurs på 45 dager som forberedelse til utøvelse av yrket som togleder og bestått kvalifikasjonseksamen, eller som innebærer åtte års grunnutdanning og fem års yrkesrettet videregående opplæring med jernbanetransport som spesialisering samt et kurs på 63 dager som forberedelse til utøvelse av yrket som togleder og bestått kvalifikasjonseksamen.

5. Utdanning $i$ Det forente kongerike godkjent som «National Vocational Qualifications» eller som «Scottish Vocational Qualifications»

Utdanning til

- godkjent dyrepleier (listed veterinary nurse),

- elektroingeniør i kullgruve (mine electrical engineer),

- maskiningeniør i kullgruve (mine mechanical engineer),

- tannterapeut (dental therapist),

- tannpleier (dental hygienist),

- optiker (dispensing optician),

- assisterende gruveingeniør (mine deputy),

- skifterettsdommer (insolvency practitioner),

- autorisert skjøteskriver (licensed conveyancer),

- førstestyrmann - laste-/passasjerskip - ingen begrensning (first mate - freight/passenger ships - unrestricted), 
- $\quad$ annenstyrmann - laste-/passasjerskip - ingen begrensning (second mate - freight/passenger ships - unrestricted),

- tredjestyrmann - laste-/passasjerskip - ingen begrensning (third mate - freight/passenger ships - unrestricted),

- dekksoffiser - laste-/passasjerskip - ingen begrensning (deck officer - freight/passenger ships - unrestricted),

- maskinoffiser - laste-/passasjerskip - ubegrenset område (engineer officer - freight/passenger ships - unlimited trading area),

- godkjent teknisk kyndig person innenfor avfallshåndtering (certified technically competent person in waste management),

som fører til kvalifikasjoner som er godkjent som «National Vocational Qualifications» (NVQ) eller i Skottland godkjent som «Scottish Vocational Qualifications», på nivå 3 eller 4 i Det forente kongerikes «National Framework of Vocational Qualifications».

Disse nivåene er definert slik:

- Nivå 3: Kompetanse på et bredt felt av arbeidsoppgaver i en rekke forskjellige sammenhenger der de fleste er komplekse og ikke-rutinepregede. Det medfører betydelig ansvar og selvstendighet, og innebærer ofte tilsyn med eller veiledning av andre.

- Nivå 4: Kompetanse på et bredt felt av komplekse, tekniske eller faglige arbeidsoppgaver utført i en rekke ulike sammenhenger med betydelig personlig ansvar og selvstendighet. Ansvar for andres arbeid og fordeling av ressurser er ofte en del av oppgaven. 


\section{VEDLEGG III}

\section{Liste over lovregulert utdanning nevnt i artikkel $13 \mathrm{nr} .2$ tredje ledd}

I Det forente kongerike:

Lovregulert utdanning som fører til kvalifikasjoner som er godkjent som «National Vocational Qualifications» (NVQ) eller i Skottland godkjent som «Scottish Vocational Qualifications», på nivå 3 eller 4 i Det forente kongerikes «National Framework of Vocational Qualifications».

Disse nivåene er definert slik:

- Nivå 3: Kompetanse på et bredt felt av arbeidsoppgaver utført i en rekke ulike sammenhenger der de fleste er komplekse og ikke-rutinepregede. Det medfører betydelig ansvar og selvstendighet, og innebærer ofte tilsyn med og veiledning av andre.

- Nivå 4: Kompetanse på et bredt felt av komplekse, tekniske eller faglige arbeidsoppgaver utført i en rekke ulike sammenhenger og med betydelig personlig ansvar og selvstendighet. Ansvar for andres arbeid og fordeling av ressurser er ofte en del av oppgaven.

I Tyskland:

Følgende lovregulerte utdanninger:

- Lovregulert utdanning som forbereder for yrkene teknisk assistent (technischer/technische Assistent(in)), handelsassistent (kaufmännischer/kaufmännische Assistent(in)) og yrker innenfor sosialsektoren (soziale Berufe) samt yrket offentlig godkjent åndedretts- og stemmepedagog (staatlich geprüfter Atem-, Sprech- und Stimmlehrer(in)) med en samlet utdanningstid på minst 13 år som forutsetter bestått videregående opplæring (mittlerer Bildungsabschluß), og som omfatter

i) minst tre års $\left.{ }^{1}\right)$ yrkesrettet opplæring ved en fagskole (Fachschule) avsluttet med en eksamen og eventuelt supplert med ett eller to års spesialisering som også avsluttes med en eksamen, eller

ii) minst to og et halvt år ved en fagskole (Fachschule), avsluttet med en eksamen og i tillegg minst seks måneders yrkeserfaring eller et praksisopphold på minst seks måneder ved en godkjent institusjon, eller

iii) minst to år ved en fagskole (Fachschule), avsluttet med en eksamen og i tillegg minst ett års yrkeserfaring eller et praksisopphold på minst ett år ved en godkjent institusjon.

- Lovregulert utdanning for yrkene offentlig godkjent (staatlich geprüfte(r)) tekniker (Techniker(in)), bedriftsøkonom (Betriebswirte(in)), designer (Gestalter(in)) og husmorvikar (Familienpfleger(in)) med en samlet utdanningstid på minst 16 år og som forutsetter fullført grunnskole eller tilsvarende utdanning (av en varighet på minst ni år) samt minst tre års bestått utdanning ved en yrkesskole (Berufsschule), og som etter minst to års yrkeserfaring omfatter minst to års utdanning på heltid eller en deltidsutdanning av tilsvarende varighet.

- Lovregulert utdanning og lovregulert tilleggsutdanning med en samlet varighet på minst 15 år som vanligvis forutsetter fullført grunnskole (av en varighet på minst ni år) og fullført yrkesrettet opplæring (vanligvis tre år) og som vanligvis omfatter minst to års (som regel tre års) yrkespraksis samt en eksamen i forbindelse med tilleggsutdanningen, der forberedelsen omfatter opplæringskurs som enten tas parallelt med yrkespraksisen (minst 1000 timer) eller på heltid (minst ett år).

Tyske myndigheter skal oversende Kommisjonen og de øvrige medlemsstater en liste over de utdanningsalternativer som berøres av dette vedlegg.

${ }^{1}$ Den korteste varigheten kan reduseres fra tre år til to år dersom vedkommende innehar de kvalifikasjoner som er nødvendige for adgang til universitetet («Abitur»), dvs.13 års forutgående utdanning og opplæring, eller de kvalifikasjoner som er nødvendige for adgang til «Fachhochschulen» («Fachhochschulreife»), dvs. tolv års forutgående utdanning og opplæring. 
I Nederland:

- Lovregulert utdanning med en samlet varighet på minst 15 år som vanligvis forutsetter grunnutdanning av en varighet på åtte år, pluss fire år med enten allmenn videregående opplæring på mellomnivå («MAVO») eller forberedende yrkesrettet opplæring («VBO») eller allmenn videregående opplæring på et høyere nivå, som omfatter tre eller fire år på en fagskole for yrkesrettet opplæring på mellomnivå («MBO»), avsluttet med en eksamen.

- Lovregulert utdanning med en samlet varighet på minst 16 år, som vanligvis forutsetter grunnutdanning av en varighet på åtte år, etterfulgt av fire år med minst forberedende yrkesrettet («VBO») eller allmenn videregående opplæring på et høyere nivå, som omfatter minst fire år med yrkesrettet opplæring i lærlingordningen, som omfatter minst én dag per uke med teoretisk undervisning på en skole og praktisk opplæring ved et senter for praktisk opplæring eller i en bedrift de andre dagene, og som avsluttes med en eksamen på andre eller tredje nivå.

Nederlandske myndigheter skal oversende Kommisjonen og de øvrige medlemsstater en liste over de utdanningsalternativer som berøres av dette vedlegg.

\section{I Østerrike:}

- Utdanning ved læresteder for høyere yrkesrettet opplæring (Berufsbildende Höhere Schulen) og læresteder for høyere jord- og skogbruksutdanning (Höhere Land- und Forstwirtschaftliche Lehranstalten), herunder særlige typer (einschließlich der Sonderformen), der struktur og nivå er fastsatt ved lover og forskrifter.

Denne utdanningen har en samlet varighet på minst 13 år, og omfatter fem års yrkesrettet opplæring, avsluttet med en bestått endelig eksamen som bevis på yrkeskompetanse.

- Utdanning ved håndverksmesterskoler (Meisterschulen), i håndverksmesterklasser (Meisterklassen), skoler for utdanning av håndverksmestere $\mathrm{i}$ industrien (Werkmeisterschulen) eller skole for utdanning av håndverkere $\mathrm{i}$ byggfag (Bauhandwerkerschulen), der struktur og nivå er fastsatt ved lover og forskrifter.

Denne utdanningen har en samlet varighet på minst 13 år og omfatter ni års grunnutdanning, etterfulgt av enten minst tre års yrkesrettet opplæring ved en fagskole eller minst tre års opplæring vekselvis i en bedrift og på en yrkesskole (Berufsschule), som i begge tilfeller avsluttes med en eksamen og suppleres med fullføring av minst et ett års utdanning på en håndverksmesterskole (Meisterschule), i en håndverksmesterklasse (Meisterklassen), på en skole for utdanning av håndverksmestere i industrien (Werkmeisterschulen) eller på en skole for utdanning av håndverkere i byggfag (Bauhandwerkerschulen). I de fleste tilfeller er den samlede varigheten minst 15 år, og omfatter perioder med yrkeserfaring, som enten kommer før utdanningen ved disse institusjonene eller ledsages av deltidsutdanning (minst 960 timer).

Østerrikske myndigheter skal oversende Kommisjonen og de øvrige medlemsstatene en liste over de utdanningsalternativer som berøres av dette vedlegg. 


\title{
VEDLEGG IV
}

Virksomhet knyttet til kategoriene av yrkeserfaring nevnt i artikkel 17, 18 og 19

\section{Liste I}

Næringshovedgrupper som omfattes av direktiv 64/427/EØF, endret ved direktiv 69/77/EØF, og av direktiv 68/366/EØF og 82/489/EØF

\author{
Direktiv 64/427/EØF \\ (Liberaliseringsdirektiv 64/429/EØF)
}

NICE-nomenklatur (tilsvarer noringshovedgruppene 23-40 ISIC)

\begin{tabular}{|c|c|c|}
\hline \multirow[t]{9}{*}{ Næringshovedgruppe } & 23 & Tekstilindustri \\
\hline & 232 & Foredling av tekstilråvarer på ullbearbeidingsmaskiner \\
\hline & 233 & Foredling av tekstilråvarer på bomullsbearbeidingsmaskiner \\
\hline & 234 & Foredling av tekstilråvarer på silkebearbeidingsmaskiner \\
\hline & 235 & Foredling av tekstilråvarer på lin- og hampbearbeidingsmaskiner \\
\hline & 236 & Annen tekstilfiberindustri (jute, harde fibrer osv.), repslageri \\
\hline & 237 & Veving og strikking \\
\hline & 238 & Etterbehandling av tekstiler \\
\hline & 239 & Annen tekstilindustri \\
\hline \multirow{6}{*}{ Næringshovedgruppe } & 24 & Produksjon av sko, klær og sengetøy \\
\hline & 241 & Serieproduksjon av sko (unntatt gummi- og tresko) \\
\hline & 242 & Håndsøm og reparasjon av sko \\
\hline & 243 & Produksjon av klær (unntatt pelsvarer) \\
\hline & 244 & Produksjon av madrasser og sengetøy \\
\hline & 245 & Pelsvareindustri \\
\hline \multirow[t]{7}{*}{ Næringshovedgruppe } & 25 & Tre- og korkindustri, unntatt tremøbelindustri \\
\hline & 251 & Sagbruk og høvleri \\
\hline & 252 & Produksjon av halvfabrikater av tre \\
\hline & 253 & Serieproduksjon av byggeelementer av tre og parkett \\
\hline & 254 & Produksjon av treemballasje \\
\hline & 255 & Produksjon av andre trevarer (unntatt møbler) \\
\hline & 259 & Produksjon av strå-, kurv-, kork-, flette- og børstevarer \\
\hline Næringshovedgruppe & 26 & 260 Tremøbelindustri \\
\hline \multirow[t]{3}{*}{ Næringshovedgruppe } & 27 & Treforedlingsindustri \\
\hline & 271 & Produksjon av tremasse, cellulose, papir og papp \\
\hline & 272 & Foredling av papir og papp \\
\hline Næringshovedgruppe & 28 & 280 Grafisk virksomhet og forlagsvirksomhet \\
\hline
\end{tabular}


næringshovedgruppe

næringshovedgruppe

Næringshovedgruppe
Produksjon av lær og lærvarer

Produksjon av lær (garving og beredning)

Produksjon av lærvarer

Produksjon av gummi, basisplast, kunstige og syntetiske fibrer og stivelsesprodukter

Gummi- og asbestforedling

Foredling av basisplast

Produksjon av kunstige og syntetiske fibrer

Kjemisk industri

Produksjon av kjemiske grunnstoffer og videreforedling av disse produkter

Spesialisert produksjon av kjemiske produkter, hovedsakelig for anvendelse innenfor industri og landbruk (herunder produksjon av industrielt fett og oljer av vegetabilsk eller animalsk opprinnelse innbefattet i næringshovedgruppe 312 ISIC)

Spesialisert produksjon av kjemiske produkter hovedsakelig for privat forbruk og for kontorbruk (bortsett fra framstilling av legemidler og farmasøytiske produkter (ex næringshovedgruppe 319 ISIC)

\section{Petroleumsindustri}

Produksjon av mineralprodukter (unntatt metaller)

Teglverk

Produksjon av glass og glassvarer

Produksjon av steintøy, porselen, fajanse og ildfaste produkter

Produksjon av sement, foredling av kalkstein og gipsstein

Produksjon av bygningsmaterialer og materialer til offentlige arbeider av betong, sement og gips

Bearbeiding og foredling av naturstein og produksjon av andre ikkemetalliske mineralprodukter

Jern- og metallindustri

Jern- og stålproduserende industri (i henhold til EKSF-traktaten, herunder smelteovner)

Stålrørsproduksjon

Trekkerier og kaldvalseverk

Produksjon og første foredling av ikke-jernholdige metaller

Støperier

Jern- og metallvareindustri (unntatt maskiner og transportmidler)

Smi-, press- og hammerverk

Videreforedling og overflatebehandling av stål

Produksjon av stål- og lettmetallkonstruksjoner

Bygging av kjeler og beholdere

Produksjon av verktøy og artikler av metall (unntatt elektrisk materiell)

Forskjellig hjelpevirksomhet for mekanisk industri 


\begin{tabular}{|c|c|c|}
\hline \multirow[t]{10}{*}{ Næringshovedgruppe } & 36 & Maskinindustri \\
\hline & 361 & Produksjon av landbruksmaskiner og traktorer \\
\hline & 362 & Produksjon av kontormaskiner \\
\hline & 363 & $\begin{array}{l}\text { Produksjon av metallbearbeidingsmaskiner, innretninger for maskiner og } \\
\text { maskinverktøy }\end{array}$ \\
\hline & 364 & Produksjon av tekstilmaskiner med tilbehør og symaskiner \\
\hline & 365 & $\begin{array}{l}\text { Produksjonavmaskinerog apparater fornærings-ognytelsesmiddelindustrien, } \\
\text { kjemisk industri og tilknyttet industri }\end{array}$ \\
\hline & 366 & $\begin{array}{l}\text { Produksjon av smelte- og valseverksinnretninger, bergverksmaskiner, } \\
\text { støperimaskiner, bygningsmaskiner, løfte- og frakteinnretninger }\end{array}$ \\
\hline & 367 & Produksjon av tannhjul, drivhjul, valselagre og andre drivkraftelementer \\
\hline & 368 & Produksjon av maskiner for andre bestemte industribransjer \\
\hline & 369 & Produksjon av andre maskiner og apparater \\
\hline \multirow[t]{10}{*}{ Næringshovedgruppe } & 37 & Elektronisk industri \\
\hline & 371 & Produksjon av isolerte elektrokabler og ledninger \\
\hline & 372 & $\begin{array}{l}\text { Produksjon av elektromotorer, generatorer og transformatorer og fordelings- } \\
\text { og installasjonsutstyr }\end{array}$ \\
\hline & 373 & Produksjon av industrielt elektrisk utstyr \\
\hline & 374 & $\begin{array}{l}\text { Produksjon av telekommunikasjonsutstyr, måle- og regneapparater og } \\
\text { elektromedisinske apparater }\end{array}$ \\
\hline & 375 & $\begin{array}{l}\text { Produksjon av radio- og fjernsynsmottakere, elektroakustisk utstyr og } \\
\text { elektronisk utstyr }\end{array}$ \\
\hline & 376 & Produksjon av elektriske husholdningsapparater \\
\hline & 377 & Produksjon av lamper og belysningsartikler \\
\hline & 378 & Produksjon av batterier og akkumulatorer \\
\hline & 379 & Reparasjon montering og teknisk installasjon av elektroniske produkter \\
\hline \multirow{5}{*}{$\begin{array}{l}\text { ex } \\
\text { næringshovedgruppe }\end{array}$} & 38 & Produksjon av transportmidler \\
\hline & 383 & Produksjon av motorvogner og motorvogndeler \\
\hline & 384 & Motorvogn- og sykkelreparasjonsverksteder \\
\hline & 385 & Produksjon av motorsykler, sykler og deler til disse \\
\hline & 389 & Produksjon av andre transportmidler \\
\hline \multirow[t]{9}{*}{ Næringshovedgruppe } & 39 & Finmekanikk, optikk og annen foredlingsvirksomhet \\
\hline & 391 & Produksjon av finmekaniske produkter, måle- og kontrollapparater \\
\hline & 392 & $\begin{array}{l}\text { Produksjon av medisinsk-mekaniske og ortopedisk-mekaniske produkter } \\
\text { (unntatt ortopedisk skotøy) }\end{array}$ \\
\hline & 393 & Produksjon av optisk og fotografisk utstyr \\
\hline & 394 & Produksjon og reparasjon av ur \\
\hline & 395 & Produksjon av smykke- og gullsmedvarer, bearbeiding av edelstener \\
\hline & 396 & Produksjon og reparasjon av musikkinstrumenter \\
\hline & 397 & Produksjon av leke- og sportsvarer \\
\hline & 399 & Annen foredlingsvirksomhet \\
\hline \multirow[t]{6}{*}{ Næringshovedgruppe } & 40 & Bygg- og anleggsvirksomhet \\
\hline & 400 & $\begin{array}{l}\text { Alminnelig bygg- og anleggsvirksomhet (ikke spesialisert), } \\
\text { nedrivningsvirksomhet }\end{array}$ \\
\hline & 401 & Oppføring av råbygg (for beboelseshus og annet) \\
\hline & 402 & Anleggsvirksomhet, bygging av veier, broer, jernbaner osv. \\
\hline & 403 & Installasjonsvirksomhet \\
\hline & 404 & Innredningsvirksomhet \\
\hline
\end{tabular}


Direktiv 68/366/EØF

(liberaliseringsdirektiv 68/365/EØF)

NICE-nomenklatur

$\begin{array}{lll}\text { Næringshovedgruppe } & \text { 20A } & \text { 200 Produksjon av vegetabilske og animalske oljer og fett } \\ \text { 20B } & \text { Produksjon av næringsmidler, unntatt drikkevarer } \\ 201 & \text { Slakting og produksjon av kjøttvarer, herunder kjøtthermetikk } \\ 202 & \text { Produksjon av meierivarer } \\ 203 & \text { Konservering av frukt og grønnsaker } \\ 204 & \text { Konservering av fisk og andre produkter fra havet } \\ 205 & \text { Produksjon av kornvarer } \\ 206 & \text { Produksjon av baker- og konditorvarer } \\ 207 & \text { Sukkerindustri } \\ 208 & \text { Produksjon av kakao, sjokolade og andre sukkervarer } \\ 209 & \text { Produksjon av næringsmidler ellers } \\ 21 & \text { Produksjon av drikkevarer } \\ 211 & \text { Produksjon av etylalkohol ved gjæring, gjær og sprit } \\ 212 & \text { Produksjon av vin og alkoholholdige drikkevarer uten malt } \\ 213 & \text { Produksjon av øl, malt og maltdrikker } \\ 214 & \text { Tapping av mineralvann og produksjon av alkoholfrie drikkevarer } \\ \text { ex } 30 & \begin{array}{l}\text { Foredling av gummi, basisplast, kunstige og syntetiske fibrer og } \\ \text { stivelsesprodukter }\end{array} \\ 304 & \text { Produksjon av stivelsesprodukter } \\ & \text { ISIC-nomenklatur } \\ & \\ & \end{array}$

ex 855 Frisørvirksomhet (unntatt fotterapeutvirksomhet og fagskoler for skjønnhetspleie)

\section{Liste II}

Næringshovedgrupper som omfattes av direktiv 75/368/EØF, 75/369/EØF, og 82/470/EØF

1

Direktiv 75/368/EØF (virksomhet vist til i artikkel $5 \mathrm{nr}$. 1)

ISIC-nomenklatur

ex $04 \quad$ Fiske

$043 \quad$ Innlandsfiske

ex 38 Produksjon av transportmidler

$381 \quad$ Skipsbygging og reparasjon av skip

382 Produksjon av jernbanemateriell

$386 \quad$ Produksjon av luftfartøy (herunder romfartsmateriell) 
Virksomhet knyttet til transport og annen virksomhet enn transport innenfor følgende grupper:

ex 711 Drift av sove- og spisevogner, vedlikehold av jernbanemateriell på reparasjonsverksteder, rengjøring av jernbanevogner

ex 712 Vedlikehold av materiell til persontransport i by- og forstadsområder samt mellom byer

ex 713 Vedlikehold av annet materiell til persontransport på landevei (f.eks. biler, rutebiler, drosjer)

ex 714 Drift og vedlikehold av anlegg i forbindelse med landeveistransport (f.eks. landeveier, tunneler og broer med bompenger, rutebilstasjoner, parkeringsplasser, vognstaller for buss og sporvogner)

ex 716 Virksomhet knyttet til transport på innlands vannvei (f.eks. drift og vedlikehold av vannvei, havner og andre anlegg for transport på innlands vannvei; bukserings- og losvirksomhet i havner, merking av farvann, lasting og lossing av fartøy og andre tilsvarende virksomheter som f.eks. berging av skip, tauing, drift av båthus)

Kommunikasjon: posttjenester og telekommunikasjoner

ex 85

Personlig tjenesteyting

$854 \quad$ Vask, kjemisk rensing, farging

ex 856 Fotografatelier: portrettfotografering, kommersiell fotografering, unntatt pressefotografer

ex 859 Personlig tjenesteyting ikke nevnt andre steder (bare vedlikehold og rengjøring av bygninger eller lokaler)

Direktiv 75/369/EØF (artikkel 6:der virksomheten anses for å vaere industri- eller håndverksvirksomhet)

\section{ISIC-nomenklatur}

Følgende virksomhet utenom fast utsalgssted:

a) Kjøp og salg av varer

- $\quad$ ved omreisende selgere, dørselgere og gateselgere (ex næringshovedgruppe 612 ISIC),

- utenom faste anlegg i salgshaller, og på torg,

b) virksomhet som omfattes av overgangstiltak som allerede er vedtatt, og som uttrykkelig utelukker eller unnlater å nevne utøvelse av slik virksomhet utenom fast utsalgssted.

Direktiv 82/470/EØF (artikkel $6 \mathrm{nr} .1$ og 3)

Gruppe 718 og 720 i ISIC-nomenklaturen

Virksomheten består særlig i

- $\quad$ å tilrettelegge, tilby og selge, til fast pris eller mot provisjon, enkeltstående eller samlede arrangementer i forbindelse med en reise eller et opphold (transport, kost, losji, utflukter osv.), uansett formålet med reisen (artikkel 2 avsnitt B bokstav a)),

_ å opptre som mellommann mellom speditører innenfor de forskjellige transportformene og avsenderne eller mottakerne av gods samt å utføre forskjellige oppgaver i tilknytning til dette, for eksempel

a) ved å inngå kontrakter med speditørene for oppdragsgivernes regning,

bb) ved å velge den transportformen, det foretaket og den ruten som anses mest fordelaktig for oppdragsgiveren,

cc) ved å sørge for den praktiske tilrettelegging av transporten (f.eks. nødvendig emballasje) og utføre forskjellige tilleggsoppgaver under transporten (f.eks. sørge for isforsyning til kjølevogner),

dd) vedåutføreformaliteteneiforbindelsemed transporten,f.eks. utstedefraktbrev, ogå samleog fordele forsendelser, 
ee) ved å samordne de forskjellige transportetappene ved å sørge for transitt, videreforsendelse og omlasting og forskjellige avsluttende oppgaver,

ff) ved å sørge for frakt til transportørene og transportmuligheter for avsendere og mottakere av gods,

- å beregne transportkostnadene og kontrollere avregningen av disse,

- å treffe visse midlertidige eller varige tiltak i en reders eller en sjøtransportvirksomhets navn og for dennes regning (overfor havnemyndigheter, skipsutstyrsfirmaer osv.).

Virksomhet nevnt i artikkel 2 avsnitt A bokstav a), b) og d).

Liste III

Direktiv 64/222/EØF, 68/364/EØF, 68/368/EØF, 75/368/EØF, 75/369/EØF, 70/523/EØF og 82/470/EØF

Direktiv 64/222/EØF

(liberaliseringsdirektiv 64/223/EØF og 64/224/EØF)

1. Selvstendig virksomhet innenfor engroshandel, med unntak av engroshandel med legemidler og farmasøytiske produkter, med giftige produkter og sykdomsframkallende stoffer eller med kull (ex gruppe 611).

2. Yrkesvirksomhet som mellommann som i henhold til en eller flere fullmakter har i oppdrag å forberede eller avslutte forretninger $i$ en annens navn og for en annens regning.

3. Yrkesvirksomhet som mellommann som, uten å ha varig oppdrag, etablerer forbindelser mellom personer som ønsker å inngå kontrakter direkte med hverandre, forbereder deres forretninger eller hjelper til med avslutningen av disse.

4. Yrkesvirksomhet som mellommann, som avslutter forretninger i eget navn for en annens regning.

5. Yrkesvirksomhet som mellommann, som gjennomfører engroshandelsauksjoner for en annens regning.

6. Yrkesvirksomhet som mellommann, som går fra dør til dør for å oppta bestillinger.

7. Yrkesvirksomhet som består i tjenesteyting av en lønnet mellommann som er i lønnet arbeid hos et eller flere foretak innenfor handel, industri eller håndverk.

Direktiv 68/364/EØF

(liberaliseringsdirektiv 68/363/EØF)

Ex gruppe 612 ISIC: Detaljhandel

Virksomhet som er unntatt:

012

640
Utleie av landbruksmaskiner

Omsetning av fast eiendom, utleie

Utleie av motorvogner, vogner og hester

Utleie av jernbanevogner og -godsvogner

Utleie av maskiner til handelsbedrifter

Utleie av kinoplasser og -filmer

Utleie av teaterplasser og teaterutstyr

Utleie av skip, båter, sykler og myntautomater

Utleie av møblerte rom

Utleie av lintøy

Utleie av klær 
Direktiv 68/368/EØF

(liberaliseringsdirektiv 68/367/EØF)

ISIC-nomenklatur

Ex næringshovedgruppe 85 ISIC:

1. Restauranter og skjenkesteder (gruppe 852 ISIC)

2. Hoteller og andre overnattingssteder og campingplasser (gruppe 853 ISIC)

Direktiv 75/368/EØF (artikkel 7)

All virksomhet oppført $i$ vedlegget til direktiv 75/368/EØF bortsett fra virksomhet som er nevnt $i$ artikkel $5 \mathrm{nr} .1 \mathrm{i}$ dette direktiv (liste II $\mathrm{nr}$. 1 i dette vedlegg).

\section{ISIC-nomenklatur}

ex $62 \quad$ Banker og andre finansinstitusjoner

ex $620 \quad$ Foretak som kjøper og lisensierer patentrettigheter

ex $71 \quad$ Transport

ex 713 Persontransport på landevei, unntatt transport med motorkjøretøyer

ex 719 Transport i rørledninger av hydrokarboner og andre flytende kjemiske produkter

ex $82 \quad$ Samfunnstjenester

827 Biblioteker, museer, botaniske og zoologiske hager

ex $84 \quad$ Fritidsaktiviteter

843 Fritidsaktiviteter som ikke er oppført andre steder:

- Idrettsaktiviteter (idrettsplasser, arrangement av idrettsstevner osv.), unntatt virksomhet som idrettsinstruktør

- Spill (veddeløpsstaller, spillebaner, veddeløpsbaner osv.)

- Andre fritidstilbud (sirkus, fornøyelsesparker og annen underholdning )

ex $85 \quad$ Personlige tjenester

ex $851 \quad$ Hushjelp

ex 855 Skjønnhetspleie og manikyrvirksomhet, unntatt pedikyrvirksomhet og fagskoler for skjønnhetspleie og frisører

ex 859 Personlige tjenester ikke nevnt annet sted, unntatt idrettsmassasje og paramedisinsk massasje utført av ikke-legeutdannede personer, og dessuten fjellførervirksomhet, gruppert som følger:

- Desinfeksjon og skadedyrbekjempelse

- Utleie av klær og oppbevaring

- Ekteskapsbyråer og liknende virksomhet

- Virksomhet som har karakter av sannsiger- og spådomsvirksomhet

- Tjenester innenfor hygiene og virksomhet knyttet til dette

- Begravelsesbyråer og vedlikehold av kirkegårder

- Reiseledere og turisttolker 
Følgende virksomhet uten fast utsalgssted:

a) Kjøp og salg av varer

- ved omreisende selgere, dørselgere og gateselgere (ex gruppe 612 ISIC),

- uten faste anlegg i salgshaller, og på torg,

b) virksomhet som omfattes av overgangstiltak som allerede er vedtatt, og som uttrykkelig utelukker eller unnlater å nevne utøvelse av slik virksomhet uten fast utsalgssted.

6

\section{Direktiv 70/523/EØF}

Selvstendig virksomhet innenfor engroshandel med kull og mellommannsvirksomhet innenfor kullhandel (ex gruppe 6112 ISIC)

$$
7
$$

$$
\text { Direktiv 82/470/EØF (artikkel } 6 \text { nr. 2) }
$$

Virksomhet nevnt i artikkel 2 avsnitt A bokstav c) og e), avsnitt B bokstav b), avsnitt C og avsnitt D

Disse formene for virksomhet består særlig i

- $\quad$ å leie jernbanevogner til person- eller godstransport,

_ $\quad$ å opptre som mellommann ved kjøp, salg eller leie av fartøyer,

- $\quad$ å utarbeide, forhandle og avslutte kontrakter om transport av utvandrere,

- $\quad$ å motta til oppbevaring for deponentens regning alle slags gjenstander og varer, uansett om disse er undergitt tollbehandling eller ikke, i lager, pakkhus, møbellager, kjølelager, siloer osv.,

- $\quad$ å utstede til deponente en kvittering for den gjenstand eller vare som er mottatt til oppbevaring,

- $\quad$ å skaffe innhegninger, fôr og salgssteder for kveg i midlertidig forvaring, enten i påvente av salg, eller i transitt til eller fra markedet,

- kontroll eller teknisk vurdering av motorkjøretøyer,

- å måle og veie varer. 
$V E D L E G G V$

Godkjenning på grunnlag av samordning av minstekrav til utdanning

V.1. LEGE

5.1.1. Kvalifikasjonsbevis - medisinsk grunnutdanning

\begin{tabular}{|c|c|c|c|c|}
\hline Stat & Kvalifikasjonsbevis & $\begin{array}{l}\text { Organ som utsteder } \\
\text { kvalifikasjonsbeviset }\end{array}$ & $\begin{array}{l}\text { Attest som ledsager } \\
\text { kvalifikasjonsbeviset }\end{array}$ & Referansedato \\
\hline $\begin{array}{l}\text { België/ } \\
\text { Belgique/ } \\
\text { Belgien }\end{array}$ & $\begin{array}{l}\text { Diploma van arts/Diplôme de } \\
\text { docteur en médecine }\end{array}$ & $\begin{array}{l}\text { Les universités/De } \\
\text { universiteiten } \\
\text { - } \quad \text { Le Jury compétent } \\
\text { d'enseignement de } \\
\text { la Communauté } \\
\text { française/De bevoegde } \\
\text { Examencommissie van de } \\
\text { Vlaamse Gemeenschap }\end{array}$ & & 20. desember 1976 \\
\hline $\begin{array}{l}\text { Česká } \\
\text { republika }\end{array}$ & $\begin{array}{l}\text { Diplom o ukončení studia ve } \\
\text { studijním programu všeobecné } \\
\text { lékařství (doktor medicíny, } \\
\text { MUDr.) }\end{array}$ & $\begin{array}{l}\text { Lékářská fakulta univerzity v } \\
\text { České republice }\end{array}$ & $\begin{array}{l}\text { - Vysvědčení o státní } \\
\text { rigorózní zkoušce }\end{array}$ & 1. mai 2004 \\
\hline Danmark & $\begin{array}{l}\text { Bevis for bestået } \\
\text { lægevidenskabelig } \\
\text { embedseksamen }\end{array}$ & Medicinsk universitetsfakultet & 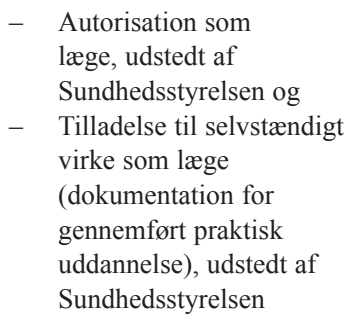 & 20. desember 1976 \\
\hline Deutschland & $\begin{array}{l}\text { - Zeugnis über die Ärztliche } \\
\text { Prüfung } \\
\text { - } \text { Zeugnis über die } \\
\text { Ärztliche Staatsprüfung } \\
\text { und Zeugnis über die } \\
\text { Vorbereitungszeit als } \\
\text { Medizinalassistent, soweit } \\
\text { diese nach den deutschen } \\
\text { Rechtsvorschriften noch } \\
\text { für den Abschluss der } \\
\text { ärztlichen Ausbildung } \\
\text { vorgesehen war }\end{array}$ & Zuständige Behörden & & 20. desember 1976 \\
\hline Eesti & $\begin{array}{l}\text { Diplom arstiteaduse õppekava } \\
\text { läbimise kohta }\end{array}$ & Tartu Ülikool & & 1. mai 2004 \\
\hline $\mathrm{E} \lambda \lambda \alpha \dot{\alpha} \varsigma$ & 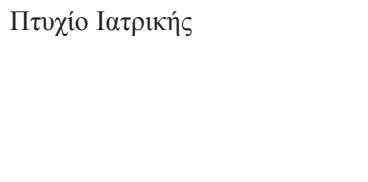 & 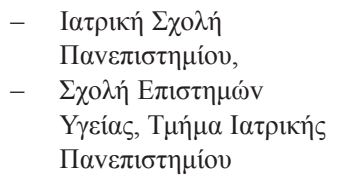 & & 1. januar 1981 \\
\hline España & $\begin{array}{l}\text { Título de Licenciado en } \\
\text { Medicina y Cirugía }\end{array}$ & $\begin{array}{l}\text { - Ministerio de Educación y } \\
\text { Cultura } \\
-\quad \text { El rector de una } \\
\text { Universidad }\end{array}$ & & 1. januar 1986 \\
\hline France & $\begin{array}{l}\text { Diplôme d'Etat de docteur en } \\
\text { médecine }\end{array}$ & Universités & & 20. desember 1976 \\
\hline Ireland & Primary qualification & Competent examining body & Certificate of experience & 20. desember 1976 \\
\hline Italia & $\begin{array}{l}\text { Diploma di laurea in medicina } \\
\text { e chirurgia }\end{array}$ & Università & $\begin{array}{l}\text { Diploma di abilitazione } \\
\text { all'esercizio della medicina e } \\
\text { chirurgia }\end{array}$ & 20. desember 1976 \\
\hline
\end{tabular}




\begin{tabular}{|c|c|c|c|c|}
\hline Stat & Kvalifikasjonsbevis & $\begin{array}{l}\text { Organ som utsteder } \\
\text { kvalifikasjonsbeviset }\end{array}$ & $\begin{array}{l}\text { Attest som ledsager } \\
\text { kvalifikasjonsbeviset }\end{array}$ & Referansedato \\
\hline 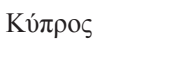 & 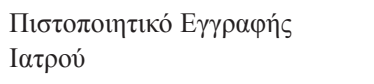 & 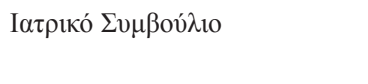 & & 1. mai 2004 \\
\hline Latvija & ārsta diploms & Universitātes tipa augstskola & & 1. mai 2004 \\
\hline Lietuva & $\begin{array}{l}\text { Aukštojo mokslo diplomas, } \\
\text { nurodantis suteiktą gydytojo } \\
\text { kvalifikaciją }\end{array}$ & Universitetas & $\begin{array}{l}\text { Internatūros pažymèjimas, } \\
\text { nurodantis suteiktą medicinos } \\
\text { gydytojo profesinę kvalifikaciją }\end{array}$ & 1. mai 2004 \\
\hline Luxembourg & $\begin{array}{l}\text { Diplôme d'Etat de docteur } \\
\text { en médecine, chirurgie et } \\
\text { accouchements, }\end{array}$ & Jury d'examen d'Etat & Certificat de stage & 20. desember 1976 \\
\hline Magyarország & $\begin{array}{l}\text { Általános orvos oklevél (doctor } \\
\text { medicinae univer- sae, röv.: dr. } \\
\text { med. univ.) }\end{array}$ & Egyetem & & 1. mai 2004 \\
\hline Malta & $\begin{array}{l}\text { Lawrja ta' Tabib tal-Medi- cina } \\
\text { u l-Kirurgijia }\end{array}$ & Universita' ta' Malta & $\begin{array}{l}\text { Certifikat ta' reġistrazzjoni } \\
\text { maћrug mill-Kunsill Mediku }\end{array}$ & 1. mai 2004 \\
\hline Nederland & $\begin{array}{l}\text { Getuigschrift van met goed } \\
\text { gevolg afgelegd artsexamen }\end{array}$ & Faculteit Geneeskunde & & 20. desember 1976 \\
\hline \multirow[t]{2}{*}{ Österreich } & $\begin{array}{l}\text { 1. Urkunde über die } \\
\text { Verleihung des akademischen } \\
\text { Grades Doktor der gesamten } \\
\text { Heilkunde (bzw. Doctor } \\
\text { medicinae universae, Dr.med. } \\
\text { univ.) }\end{array}$ & $\begin{array}{l}\text { 1. Medizinische Fakultät einer } \\
\text { Universität }\end{array}$ & & \multirow[t]{2}{*}{ 1. januar 1994} \\
\hline & $\begin{array}{l}\text { 2. Diplom über die spezifische } \\
\text { Ausbildung zum Arzt für } \\
\text { Allgemeinmedizin bzw. } \\
\text { Facharztdiplom }\end{array}$ & $\begin{array}{l}\text { 2. Österreichische } \\
\text { Ärztekammer }\end{array}$ & & \\
\hline Polska & $\begin{array}{l}\text { Dyplom ukończenia studiów } \\
\text { wyższych na kierunku } \\
\text { lekarskim z tytułem «lekarza» }\end{array}$ & $\begin{array}{l}\text { 1. Akademia Medyczna } \\
\text { 2. Uniwersytet Medyczny } \\
\text { 3. Collegium Medicum } \\
\text { Uniwersytetu Jagiellońskiego }\end{array}$ & Lekarski Egzamin Państwowy & 1. mai 2004 \\
\hline Portugal & $\begin{array}{l}\text { Carta de Curso de licenciatura } \\
\text { em medicina }\end{array}$ & Universidades & $\begin{array}{l}\text { Diploma comprovativo da } \\
\text { conclusão do internato geral } \\
\text { emitido pelo Ministério da } \\
\text { Saúde }\end{array}$ & 1. januar 1986 \\
\hline Slovenija & $\begin{array}{l}\text { Diploma, s katero se podeljuje } \\
\text { strokovni naslov «doktor } \\
\text { medicine/doktorica medicine» }\end{array}$ & Univerza & & 1. mai 2004 \\
\hline Slovensko & $\begin{array}{l}\text { Vysokoškolský diplom o } \\
\text { udelení akademického titulu } \\
\text { «doktor medicíny» («MUDr.») }\end{array}$ & Vysoká škola & & 1. mai 2004 \\
\hline Suomi/ Finland & $\begin{array}{l}\text { Lääketieteen lisensiaatin } \\
\text { tutkinto/Medicine } \\
\text { licentiatexamen }\end{array}$ & $\begin{array}{ll}- & \text { Helsingin yliopisto/ } \\
& \text { Helsingfors universitet } \\
- & \text { Kuopion yliopisto } \\
- & \text { Oulun yliopisto } \\
- & \text { Tampereen yliopisto } \\
- & \text { Turun yliopisto }\end{array}$ & $\begin{array}{l}\text { Todistus läkärin } \\
\text { perusterveydenhuollon } \\
\text { lisäkoulutuksesta/Examenbevis } \\
\text { om tilläggsutbildning för läkare } \\
\text { inom primärvården }\end{array}$ & 1. januar 1994 \\
\hline Sverige & Läkarexamen & Universitet & $\begin{array}{l}\text { Bevis om praktisk utbildning } \\
\text { som utfärdas av Socialstyrelsen }\end{array}$ & 1. januar 1994 \\
\hline $\begin{array}{l}\text { United } \\
\text { Kingdom }\end{array}$ & Primary qualification & Competent examining body & Certificate of experience & 20. desember 1976 \\
\hline
\end{tabular}


5.1.2. Kvalifikasjonsbevis - lege med spesialistutdanning

\begin{tabular}{|c|c|c|c|}
\hline Stat & Kvalifikasjonsbevis & Organ som utsteder kvalifikasjonsbeviset & Referansedato \\
\hline $\begin{array}{l}\text { België/ } \\
\text { Belgique/ } \\
\text { Belgien }\end{array}$ & $\begin{array}{l}\text { Bijzondere beroepstitel van geneesheer- } \\
\text { specialist/Titre professionnel particulier de } \\
\text { médecin spécialiste }\end{array}$ & $\begin{array}{l}\text { Minister bevoegd voor Volksgezondheid/ } \\
\text { Ministre de la Santé publique }\end{array}$ & 20. desember 1976 \\
\hline $\begin{array}{l}\text { Česká } \\
\text { republika }\end{array}$ & Diplom o specializaci & Ministerstvo zdravotnictví & 1. mai 2004 \\
\hline Danmark & $\begin{array}{l}\text { Bevis for tilladelse til at betegne sig som } \\
\text { speciallæge }\end{array}$ & Sundhedsstyrelsen & 20. desember 1976 \\
\hline Deutschland & Fachärztliche Anerkennung & Landesärztekammer & 20. desember 1976 \\
\hline Eesti & Residentuuri lõputunnistus eriarstiabi erialal & Tartu Ülikool & 1. mai 2004 \\
\hline \multirow[t]{2}{*}{ 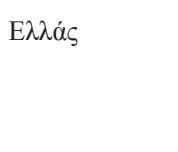 } & \multirow[t]{2}{*}{ 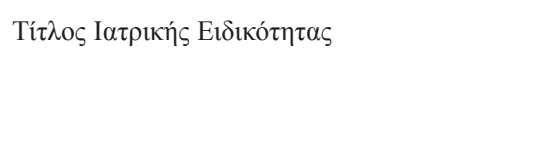 } & 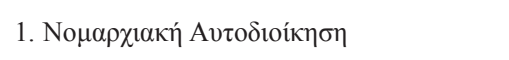 & \multirow[t]{2}{*}{ 1. januar 1981} \\
\hline & & 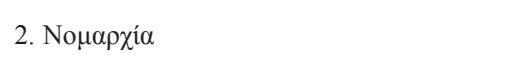 & \\
\hline España & Título de Especialista & Ministerio de Educación y Cultura & 1. januar 1986 \\
\hline \multirow[t]{4}{*}{ France } & 1. Certificat d'études spéciales de médecine & 1. Universités & \multirow[t]{4}{*}{ 20. desember 1976} \\
\hline & 2. Attestation de médecin spécialiste qualifié & 2. Conseil de l’Ordre des médecins & \\
\hline & 3. Certificat d'études spéciales de médecine & 3. Universités & \\
\hline & $\begin{array}{l}\text { 4. Diplôme d'études spécialisées ou } \\
\text { spécialisation complémentaire qualifiante de } \\
\text { médecine }\end{array}$ & 4. Universités & \\
\hline Ireland & Certificate of Specialist doctor & Competent authority & 20. desember 1976 \\
\hline Italia & Diploma di medico specialista & Università & 20. desember 1976 \\
\hline Kór $\rho \circ \varsigma$ & 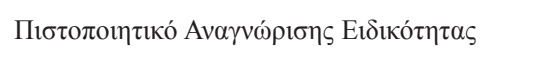 & 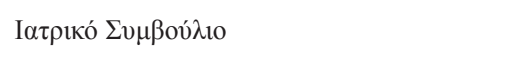 & 1. mai 2004 \\
\hline Latvija & $\begin{array}{l}\text { «Sertifikāts»—-kompetentu iestāžu izsniegts } \\
\text { dokuments, kas apliecina, ka persona ir } \\
\text { nokārtojusi sertifikācijas eksāmenu specialitātē }\end{array}$ & $\begin{array}{l}\text { Latvijas Ārstu biedrība } \\
\text { Latvijas Ārstniecības personu profesionālo } \\
\text { organizāciju savienība }\end{array}$ & 1. mai 2004 \\
\hline Lietuva & $\begin{array}{l}\text { Rezidentūros pažymèjimas, nurodantis suteiktą } \\
\text { gydytojo specialisto profesinę kvalifikaciją }\end{array}$ & Universitetas & 1. mai 2004 \\
\hline Luxembourg & Certificat de médecin spécialiste & Ministre de la Santé publique & 20. desember 1976 \\
\hline Magyarország & Szakorvosi bizonyítvány & $\begin{array}{l}\text { Az Egészségügyi, Szociális és Családügyi } \\
\text { Minisztérium illetékes testülete }\end{array}$ & 1. mai 2004 \\
\hline Malta & Ċertifikat ta' Speċjalista Mediku & Kumitat ta' Approvazzjoni dwar Specjjalisti & 1. mai 2004 \\
\hline
\end{tabular}




\begin{tabular}{|c|c|c|c|}
\hline Stat & Kvalifikasjonsbevis & Organ som utsteder kvalifikasjonsbeviset & Referansedato \\
\hline Nederland & $\begin{array}{l}\text { Bewijs van inschrijving in een } \\
\text { Specialistenregister }\end{array}$ & $\begin{array}{l}\text { - Medisch Specialisten Registratie Commissie } \\
\text { (MSRC) van de Koninklijke Nederlandsche } \\
\text { Maatschappij tot Bevordering der } \\
\text { Geneeskunst } \\
\text { - } \\
\text { Sociaal-Geneeskundigen Registratie } \\
\text { Commissie van de Koninklijke } \\
\text { Nederlandsche Maatschappij tot } \\
\text { Bevordering der Geneeskunst }\end{array}$ & 20. desember 1976 \\
\hline Österreich & Facharztdiplom & Österreichische Ärztekammer & 1. januar 1994 \\
\hline Polska & Dyplom uzyskania tytułu specjalisty & Centrum Egzaminów Medycznych & 1. mai 2004 \\
\hline \multirow[t]{2}{*}{ Portugal } & 1. Grau de assistente & 1. Ministério da Saúde & \multirow[t]{2}{*}{ 1. januar 1986} \\
\hline & 2. Titulo de especialista & 2. Ordem dos Médicos & \\
\hline \multirow[t]{2}{*}{ Slovenija } & \multirow[t]{2}{*}{ Potrdilo o opravljenem specialističnem izpitu } & 1. Ministrstvo za zdravje & \multirow[t]{2}{*}{ 1. mai 2004} \\
\hline & & 2. Zdravniška zbornica Slovenije & \\
\hline Slovensko & Diplom o špecializácii & Slovenská zdravotnícka univerzita & 1. mai 2004 \\
\hline \multirow[t]{5}{*}{ Suomi/ Finland } & \multirow[t]{5}{*}{ Erikoislääkärin tutkinto/Specialläkarexamen } & 1. Helsingin yliopisto/Helsingfors universitet & \multirow[t]{5}{*}{ 1. januar 1994} \\
\hline & & 2. Kuopion yliopisto & \\
\hline & & 3. Oulun yliopisto & \\
\hline & & 4. Tampereen yliopisto & \\
\hline & & 5. Turun yliopisto & \\
\hline Sverige & $\begin{array}{l}\text { Bevis om specialkompetens som läkare, utfärdat } \\
\text { av Socialstyrelsen }\end{array}$ & Socialstyrelsen & 1. januar 1994 \\
\hline $\begin{array}{l}\text { United } \\
\text { Kingdom }\end{array}$ & Certificate of Completion of specialist training & Competent authority & 20. desember 1976 \\
\hline
\end{tabular}

\subsubsection{Betegnelser for spesialistutdanninger $\mathrm{i}$ medisin}

\begin{tabular}{|c|c|c|}
\hline \multirow{2}{*}{ Stat } & $\begin{array}{l}\text { Anestesiologi } \\
\text { Utdanningens korteste varighet: tre år }\end{array}$ & $\begin{array}{l}\text { Generell kirurgi } \\
\text { Utdanningens korteste varighet: fem år }\end{array}$ \\
\hline & Betegnelse & Betegnelse \\
\hline Belgique/België/Belgien & Anesthésie-réanimation/Anesthesie reanimatie & Chirurgie/Heelkunde \\
\hline Česká republika & Anesteziologie a resuscitace & Chirurgie \\
\hline Danmark & Anæstesiologi & Kirurgi elsler kirurgiske sygdomme \\
\hline Deutschland & Anästhesiologie & (Allgemeine) Chirurgie \\
\hline Eesti & Anestesioloogia & Üldkirurgia \\
\hline$E \lambda \lambda \alpha \dot{\alpha}$ & 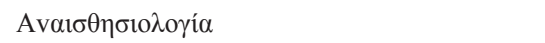 & Хвєроирүıки́ \\
\hline
\end{tabular}




\begin{tabular}{|c|c|c|}
\hline Stat & $\begin{array}{l}\text { Anestesiologi } \\
\text { Utdanningens korteste varighet: tre år }\end{array}$ & $\begin{array}{l}\text { Generell kirurgi } \\
\text { Utdanningens korteste varighet: fem år }\end{array}$ \\
\hline & Betegnelse & Betegnelse \\
\hline España & Anestesiología y Reanimación & Cirugía general y del aparato digestivo \\
\hline France & Anesthésiologie-Réanimation chirurgicale & Chirurgie générale \\
\hline Ireland & Anaesthesia & General surgery \\
\hline Italia & Anestesia e rianimazione & Chirurgia generale \\
\hline 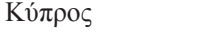 & 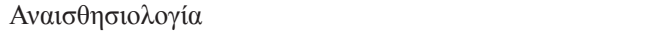 & 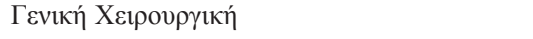 \\
\hline Latvija & Anesteziologija un reanimatologija & Ķirurǵija \\
\hline Lietuva & Anesteziologija reanimatologija & Chirurgija \\
\hline Luxembourg & Anesthésie-réanimation & Chirurgie générale \\
\hline Magyarország & Aneszteziológia és intenzív terápia & Sebészet \\
\hline Malta & Anesteżija u Kura Intensiva & Kirurġija Ġenerali \\
\hline Nederland & Anesthesiologie & Heelkunde \\
\hline Österreich & Anästhesiologie und Intensivmedizin & Chirurgie \\
\hline Polska & Anestezjologia i intensywna terapia & Chirurgia ogólna \\
\hline Portugal & Anestesiologia & Cirurgia geral \\
\hline Slovenija & $\begin{array}{l}\text { Anesteziologija, reanimatologija in perioperativna } \\
\text { intenzivna medicina }\end{array}$ & Splošna kirurgija \\
\hline Slovensko & Anestéziológia a intenzívna medicína & Chirurgia \\
\hline Suomi/Finland & Anestesiologia ja tehohoito/Anestesiologi och intensivvård & Yleiskirurgia/Allmän kirurgi \\
\hline Sverige & Anestesi och intensivvård & Kirurgi \\
\hline United Kingdom & Anaesthetics & General surgery \\
\hline
\end{tabular}




\begin{tabular}{|c|c|c|}
\hline Stat & $\begin{array}{c}\text { Nevrokirurgi } \\
\text { Utdanningens korteste varighet: fem år }\end{array}$ & $\begin{array}{l}\text { Fødselshjelp og kvinnesykdommer } \\
\text { Utdanningens korteste varighet: fire år }\end{array}$ \\
\hline & Betegnelse & Betegnelse \\
\hline Belgique/België/ Belgien & Neurochirurgie & Gynécologie - obstétrique/Gynaecologie en verloskunde \\
\hline Česká republika & Neurochirurgie & Gynekologie a porodnictví \\
\hline Danmark & Neurokirurgi eller kirurgiske nervesygdomme & $\begin{array}{l}\text { Gynækologi og obstetrik eller kvindesygdomme og } \\
\text { fødselshjælp }\end{array}$ \\
\hline Deutschland & Neurochirurgie & Frauenheilkunde und Geburtshilfe \\
\hline Eesti & Neurokirurgia & Sünnitusabi ja günekoloogia \\
\hline 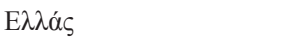 & 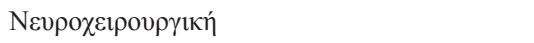 & 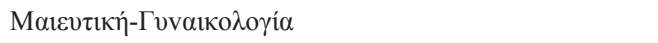 \\
\hline España & Neurocirugía & Obstetricia y ginecología \\
\hline France & Neurochirurgie & Gynécologie — obstétrique \\
\hline Ireland & Neurosurgery & Obstetrics and gynaecology \\
\hline Italia & Neurochirurgia & Ginecologia e ostetricia \\
\hline Kv́ $\pi \rho \circ$ & 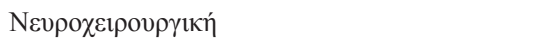 & 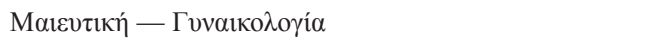 \\
\hline Latvija & Neiroķirurǵija & Ginekoloǵija un dzemdniecība \\
\hline Lietuva & Neurochirurgija & Akušerija ginekologija \\
\hline Luxembourg & Neurochirurgie & Gynécologie — obstétrique \\
\hline Magyarország & Idegsebészet & Szülészet-nőgyógyászat \\
\hline Malta & Newrokirurgija & Ostetric̈ja u Ġinekologija \\
\hline Nederland & Neurochirurgie & Verloskunde en gynaecologie \\
\hline Österreich & Neurochirurgie & Frauenheilkunde und Geburtshilfe \\
\hline Polska & Neurochirurgia & Położnictwo i ginekologia \\
\hline Portugal & Neurocirurgia & Ginecologia e obstetricia \\
\hline Slovenija & Nevrokirurgija & Ginekologija in porodništvo \\
\hline Slovensko & Neurochirurgia & Gynekológia a pôrodníctvo \\
\hline Suomi/Finland & Neurokirurgia/Neurokirurgi & $\begin{array}{l}\text { Naistentaudit ja synnytykset/Kvinnosjukdomar och } \\
\text { förlossningar }\end{array}$ \\
\hline Sverige & Neurokirurgi & Obstetrik och gynekologi \\
\hline United Kingdom & Neurosurgery & Obstetrics and gynaecology \\
\hline
\end{tabular}




\begin{tabular}{|c|c|c|}
\hline Stat & $\begin{array}{l}\text { Indremedisin } \\
\text { Utdanningens korteste varighet: fem år }\end{array}$ & $\begin{array}{l}\text { Øyesykdommer } \\
\text { Utdanningens korteste varighet: tre år }\end{array}$ \\
\hline & Betegnelse & Betegnelse \\
\hline Belgique/België/Belgien & Médecine interne/Inwendige geneeskunde & Ophtalmologie/Oftalmologie \\
\hline Česká republika & Vnitřní lékařství & Oftalmologie \\
\hline Danmark & Intern medicin & Oftalmologi eller øjensygdomme \\
\hline Deutschland & Innere Medizin & Augenheilkunde \\
\hline Eesti & Sisehaigused & Oftalmoloogia \\
\hline 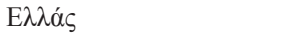 & 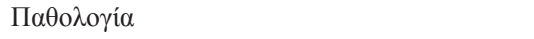 & 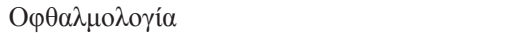 \\
\hline España & Medicina interna & Oftalmología \\
\hline France & Médecine interne & Ophtalmologie \\
\hline Ireland & General medicine & Ophthalmic surgery \\
\hline Italia & Medicina interna & Oftalmologia \\
\hline Kú $\pi \rho \circ \varsigma$ & 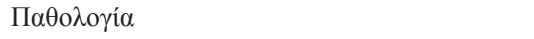 & 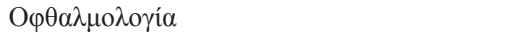 \\
\hline Latvija & Internā medicīna & Oftalmologija \\
\hline Lietuva & Vidaus ligos & Oftalmologija \\
\hline Luxembourg & Médecine interne & Ophtalmologie \\
\hline Magyarország & Belgyógyászat & Szemészet \\
\hline Malta & Medic̈ina Interna & Oftalmologija \\
\hline Nederland & Interne geneeskunde & Oogheelkunde \\
\hline Österreich & Innere Medizin & Augenheilkunde und Optometrie \\
\hline Polska & Choroby wewnętrzne & Okulistyka \\
\hline Portugal & Medicina interna & Oftalmologia \\
\hline Slovenija & Interna medicina & Oftalmologija \\
\hline Slovensko & Vnútorné lekárstvo & Oftalmológia \\
\hline Suomi/Finland & Sisätaudit/Inre medicin & Silmätaudit/Ögonsjukdomar \\
\hline Sverige & Internmedicin & Ögonsjukdomar (oftalmologi) \\
\hline United Kingdom & General (internal) medicine & Ophthalmology \\
\hline
\end{tabular}




\begin{tabular}{|c|c|c|}
\hline Stat & $\begin{array}{l}\text { Øre-nese-halssykdommer } \\
\text { Utdanningens korteste varighet: tre år }\end{array}$ & $\begin{array}{l}\text { Barnesykdommer } \\
\text { Utdanningens korteste varighet: fire år }\end{array}$ \\
\hline & Betegnelse & Betegnelse \\
\hline Belgique/België/Belgien & Oto-rhino-laryngologie/Otorhinolaryngologie & Pédiatrie/Pediatrie \\
\hline Česká republika & Otorinolaryngologie & Dětské lékařství \\
\hline Danmark & Oto-rhino-laryngologi eller øre-næse-halssygdomme & Pædiatri eller sygdomme hos børn \\
\hline Deutschland & Hals-Nasen-Ohrenheilkunde & Kinder- und Jugendmedizin \\
\hline Eesti & Otorinolarüngoloogia & Pediaatria \\
\hline 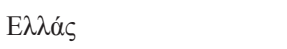 & 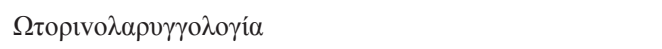 & 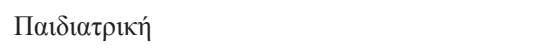 \\
\hline España & Otorrinolaringología & Pediatría y sus áreas específicas \\
\hline France & Oto-rhino-laryngologie & Pédiatrie \\
\hline Ireland & Otolaryngology & Paediatrics \\
\hline Italia & Otorinolaringoiatria & Pédiatria \\
\hline Kú $\pi \rho \circ \varsigma$ & $\Omega \tau о \rho ı v о \lambda \alpha \rho v \gamma \gamma о \lambda о \gamma i ́ \alpha$ & 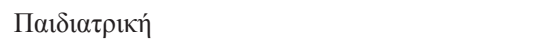 \\
\hline Latvija & Otolaringologijia & Pediatrija \\
\hline Lietuva & Otorinolaringologija & Vaikų ligos \\
\hline Luxembourg & Oto-rhino-laryngologie & Pédiatrie \\
\hline Magyarország & Fül-orr-gégegyógyászat & Csecsemő- és gyermekgyógyászat \\
\hline Malta & Otorinolaringologija & Pedjatrija \\
\hline Nederland & Keel-, neus- en oorheelkunde & Kindergeneeskunde \\
\hline Österreich & Hals-, Nasen- und Ohrenkrankheiten & Kinder- und Jugendheilkunde \\
\hline Polska & Otorynolaryngologia & Pediatria \\
\hline Portugal & Otorrinolaringologia & Pediatria \\
\hline Slovenija & Otorinolaringológija & Pediatrija \\
\hline Slovensko & Otorinolaryngológia & Pediatria \\
\hline Suomi/Finland & $\begin{array}{l}\text { Korva-, nenä- ja kurkkutaudit/Öron-, näs- och } \\
\text { halssjukdomar }\end{array}$ & Lastentaudit/Barnsjukdomar \\
\hline Sverige & Öron-, näs- och halssjukdomar (oto-rhino-laryngologi) & Barn- och ungdomsmedicin \\
\hline United Kingdom & Otolaryngology & Paediatrics \\
\hline
\end{tabular}




\begin{tabular}{|c|c|c|}
\hline Stat & $\begin{array}{l}\text { Lungesykdommer } \\
\text { Utdanningens korteste varighet: fire år }\end{array}$ & $\begin{array}{l}\text { Urologi } \\
\text { Utdanningens korteste varighet: fem år }\end{array}$ \\
\hline & Betegnelse & Betegnelse \\
\hline Belgique/België/ Belgien & Pneumologie & Urologie \\
\hline Česká republika & Tuberkulóza a respirační nemoci & Urologie \\
\hline Danmark & Medicinske lungesygdomme & Urologi eller urinvejenes kirurgiske sygdomme \\
\hline Deutschland & Pneumologie & Urologie \\
\hline Eesti & Pulmonoloogia & Uroloogia \\
\hline $\mathrm{E} \lambda \lambda \alpha \dot{\alpha} \varsigma$ & 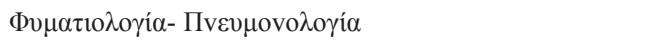 & 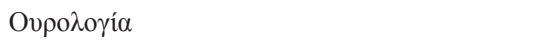 \\
\hline España & Neumología & Urología \\
\hline France & Pneumologie & Urologie \\
\hline Ireland & Respiratory medicine & Urology \\
\hline Italia & Malattie dell'apparato respiratorio & Urologia \\
\hline 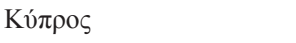 & 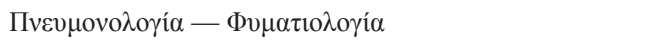 & 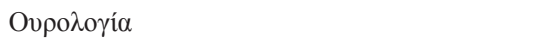 \\
\hline Latvija & Ftiziopneimonologija & Urologija \\
\hline Lietuva & Pulmonologija & Urologija \\
\hline Luxembourg & Pneumologie & Urologie \\
\hline Magyarország & Tüdőgyógyászat & Urológia \\
\hline Malta & Medicina Respiratorja & Urologija \\
\hline Nederland & Longziekten en tuberculose & Urologie \\
\hline Österreich & Lungenkrankheiten & Urologie \\
\hline Polska & Choroby płuc & Urologia \\
\hline Portugal & Pneumologia & Urologia \\
\hline Slovenija & Pnevmologija & Urologija \\
\hline Slovensko & Pneumológia a ftizeológia & Urológia \\
\hline Suomi/Finland & $\begin{array}{l}\text { Keuhkosairaudet ja allergologia/Lungsjukdomar och } \\
\text { allergologi }\end{array}$ & Urologia/Urologi \\
\hline Sverige & Lungsjukdomar (pneumologi) & Urologi \\
\hline United Kingdom & Respiratory medicine & Urology \\
\hline
\end{tabular}




\begin{tabular}{|c|c|c|}
\hline Stat & $\begin{array}{c}\text { Ortopedisk kirurgi } \\
\text { Utdanningens korteste varighet: fem år }\end{array}$ & $\begin{array}{l}\text { Patologisk anatomi } \\
\text { Utdanningens korteste varighet: fire år }\end{array}$ \\
\hline & Betegnelse & Betegnelse \\
\hline Belgique/België/Belgien & Chirurgie orthopédique/Orthopedische heelkunde & Anatomie pathologique/Pathologische anatomie \\
\hline Česká republika & Ortopedie & Patologická anatomie \\
\hline Danmark & Ortopædisk kirurgi & Patologisk anatomi eller vævs- og celleundersøgelser \\
\hline Deutschland & Orthopädie (und Unfallchirurgie) & Pathologie \\
\hline Eesti & Ortopeedia & Patoloogia \\
\hline 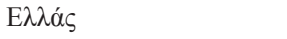 & О $\rho \theta \pi \varepsilon \varepsilon \delta 1 \kappa \eta ́$ & 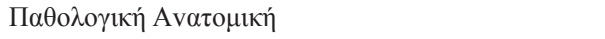 \\
\hline España & Cirugía ortopédica y traumatología & Anatomía patológica \\
\hline France & Chirurgie orthopédique et traumatologie & Anatomie et cytologie pathologiques \\
\hline Ireland & Trauma and orthopaedic surgery & Histopathology \\
\hline Italia & Ortopedia e traumatologia & Anatomia patologica \\
\hline Kú $\pi \rho \circ \varsigma$ & О $\rho \theta \pi \varepsilon \delta\llcorner\kappa \eta ́$ & 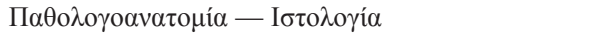 \\
\hline Latvija & Traumatologija un ortopēdija & Patologija \\
\hline Lietuva & Ortopedija traumatologija & Patologija \\
\hline Luxembourg & Orthopédie & Anatomie pathologique \\
\hline Magyarország & Ortopédia & Patológia \\
\hline Malta & Kirurgija Ortopedika & Istopatologija \\
\hline Nederland & Orthopedie & Pathologie \\
\hline Österreich & Orthopädie und Orthopädische Chirurgie & Pathologie \\
\hline Polska & Ortopedia i traumatologia narządu ruchu & Patomorfologia \\
\hline Portugal & Ortopedia & Anatomia patologica \\
\hline Slovenija & Ortopedska kirurgija & Anatomska patologija in citopatologija \\
\hline Slovensko & Ortopédia & Patologická anatómia \\
\hline Suomi/Finland & Ortopedia ja traumatologia/Ortopedi och traumatologi & Patologia/Patologi \\
\hline Sverige & Ortopedi & Klinisk patologi \\
\hline United Kingdom & Trauma and orthopaedic surgery & Histopathology \\
\hline
\end{tabular}




\begin{tabular}{|c|c|c|}
\hline Stat & $\begin{array}{l}\text { Nevrologi } \\
\text { Utdanningens korteste varighet: fire år }\end{array}$ & $\begin{array}{c}\text { Psykiatri } \\
\text { Utdanningens korteste varighet: fire år }\end{array}$ \\
\hline & Betegnelse & Betegnelse \\
\hline Belgique/België/Belgien & Neurologie & Psychiatrie de l'adulte/Volwassen psychiatrie \\
\hline Česká republika & Neurologie & Psychiatrie \\
\hline Danmark & Neurologi eller medicinske nervesygdomme & Psykiatri \\
\hline Deutschland & Neurologie & Psychiatrie und Psychotherapie \\
\hline Eesti & Neuroloogia & Psühhiaatria \\
\hline 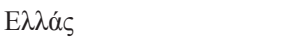 & 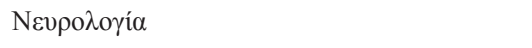 & 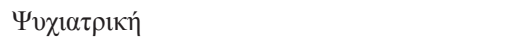 \\
\hline España & Neurología & Psiquiatría \\
\hline France & Neurologie & Psychiatrie \\
\hline Ireland & Neurology & Psychiatry \\
\hline Italia & Neurologia & Psichiatria \\
\hline 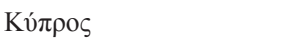 & 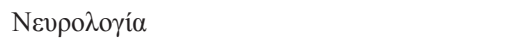 & $\Psi \nu \chi 1 \alpha \tau \rho ı n^{\prime}$ \\
\hline Latvija & Neirologija & Psihiatrija \\
\hline Lietuva & Neurologija & Psichiatrija \\
\hline Luxembourg & Neurologie & Psychiatrie \\
\hline Magyarország & Neurológia & Pszichiátria \\
\hline Malta & Newrologija & Psikjatrija \\
\hline Nederland & Neurologie & Psychiatrie \\
\hline Österreich & Neurologie & Psychiatrie \\
\hline Polska & Neurologia & Psychiatria \\
\hline Portugal & Neurologia & Psiquiatria \\
\hline Slovenija & Nevrologija & Psihiatrija \\
\hline Slovensko & Neurológia & Psychiatria \\
\hline Suomi/Finland & Neurologia/Neurologi & Psykiatria/Psykiatri \\
\hline Sverige & Neurologi & Psykiatri \\
\hline United Kingdom & Neurology & General psychiatry \\
\hline
\end{tabular}




\begin{tabular}{|c|c|c|}
\hline Stat & $\begin{array}{l}\text { Diagnostisk radiologi } \\
\text { Utdanningens korteste varighet: fire år }\end{array}$ & $\begin{array}{l}\text { Radioterapi } \\
\text { Utdanningens korteste varighet: fire år }\end{array}$ \\
\hline & Betegnelse & Betegnelse \\
\hline Belgique/België/Belgien & Radiodiagnostic/Röntgendiagnose & Radiothérapie-oncologie/Radiotherapie-oncologie \\
\hline Česká republika & Radiologie a zobrazovací metody & Radiační onkologie \\
\hline Danmark & Diagnostik radiologi eller røntgenundersøgelse & Onkologi \\
\hline Deutschland & (Diagnostische) Radiologie & Strahlentherapie \\
\hline Eesti & Radioloogia & Onkoloogia \\
\hline 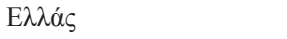 & 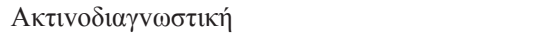 & 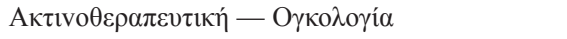 \\
\hline España & Radiodiagnóstico & Oncología radioterápica \\
\hline France & Radiodiagnostic et imagerie médicale & Oncologie radiothérapique \\
\hline Ireland & Diagnostic radiology & Radiation oncology \\
\hline Italia & Radiodiagnostica & Radioterapia \\
\hline Kú $\pi \rho \circ \varsigma$ & 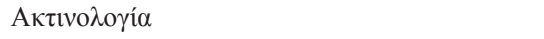 & 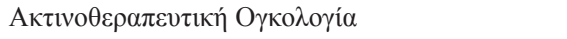 \\
\hline Latvija & Diagnostiskā radiologija & Terapeitiskā radiologija \\
\hline Lietuva & Radiologija & Onkologija radioterapija \\
\hline Luxembourg & Radiodiagnostic & Radiothérapie \\
\hline Magyarország & Radiológia & Sugárterápia \\
\hline Malta & Radjologija & Onkologija u Radjoterapija \\
\hline Nederland & Radiologie & Radiotherapie \\
\hline Österreich & Medizinische Radiologie-Diagnostik & Strahlentherapie - Radioonkologie \\
\hline Polska & Radiologia i diagnostyka obrazowa & Radioterapia onkologiczna \\
\hline Portugal & Radiodiagnóstico & Radioterapia \\
\hline Slovenija & Radiologija & Radioterapija in onkologija \\
\hline Slovensko & Rádiológia & Radiačná onkológia \\
\hline Suomi/Finland & Radiologia/Radiologi & Syöpätaudit/Cancersjukdomar \\
\hline Sverige & Medicinsk radiologi & Tumörsjukdomar (allmän onkologi) \\
\hline United Kingdom & Clinical radiology & Clinical oncology \\
\hline
\end{tabular}




\begin{tabular}{|c|c|c|}
\hline Stat & $\begin{array}{c}\text { Plastikkirurgi } \\
\text { Utdanningens korteste varighet: fem år }\end{array}$ & $\begin{array}{l}\text { Klinisk biologi } \\
\text { Utdanningens korteste varighet: fire år }\end{array}$ \\
\hline & Betegnelse & Betegnelse \\
\hline Belgique/België/Belgien & $\begin{array}{l}\text { Chirurgie plastique, reconstructrice et esthétique/ } \\
\text { Plastische, reconstructieve en esthetische heelkunde }\end{array}$ & Biologie clinique/Klinische biologie \\
\hline Česká republika & Plastická chirurgie & \\
\hline Danmark & Plastikkirurgi & \\
\hline Deutschland & Plastische (und Ästhetische) Chirurgie & \\
\hline Eesti & Plastika- ja rekonstruktiivkirurgia & Laborimeditsiin \\
\hline 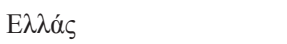 & 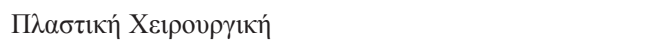 & \\
\hline España & Cirugía plástica, estética y reparadora & Análisis clínicos \\
\hline France & Chirurgie plastique, reconstructrice et esthétique & Biologie médicale \\
\hline Ireland & Plastic, reconstructive and aesthetic surgery & \\
\hline Italia & Chirurgia plastica e ricostruttiva & Patologia clinica \\
\hline Kú $\pi \rho \circ \varsigma$ & 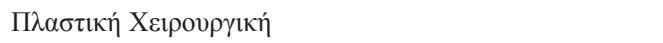 & \\
\hline Latvija & Plastiskā k̦irurǵija & \\
\hline Lietuva & Plastinė ir rekonstrukcinè chirurgija & Laboratorinè medicina \\
\hline Luxembourg & Chirurgie plastique & Biologie clinique \\
\hline Magyarország & Plasztikai (égési) sebészet & Orvosi laboratóriumi diagnosztika \\
\hline Malta & Kirurgija Plastika & \\
\hline Nederland & Plastische Chirurgie & \\
\hline Österreich & Plastische Chirurgie & Medizinische Biologie \\
\hline Polska & Chirurgia plastyczna & Diagnostyka laboratoryjna \\
\hline Portugal & Cirurgia plástica e reconstrutiva & Patologia clínica \\
\hline Slovenija & Plastična, rekonstrukcijska in estetska kirurgija & \\
\hline Slovensko & Plastická chirurgia & Laboratórna medicína \\
\hline Suomi/Finland & Plastiikkakirurgia/Plastikkirurgi & \\
\hline Sverige & Plastikkirurgi & \\
\hline United Kingdom & Plastic surgery & \\
\hline
\end{tabular}




\begin{tabular}{|c|c|c|}
\hline \multirow{2}{*}{ Stat } & $\begin{array}{c}\text { Medisinsk mikrobiologi } \\
\text { Utdanningens korteste varighet: fire år }\end{array}$ & $\begin{array}{c}\text { Klinisk kjemi } \\
\text { Utdanningens korteste varighet: fire år }\end{array}$ \\
\hline & Betegnelse & Betegnelse \\
\hline \multicolumn{3}{|c|}{ Belgique/België/ Belgien } \\
\hline Česká republika & Lékařská mikrobiologie & Klinická biochemie \\
\hline Danmark & Klinisk mikrobiologi & Klinisk biokemi \\
\hline Deutschland & Mikrobiologie (Virologie) und Infektionsepidemiologie & Laboratoriumsmedizin \\
\hline \multicolumn{3}{|l|}{ Eesti } \\
\hline$E \lambda \lambda \alpha \dot{\alpha} \varsigma$ & 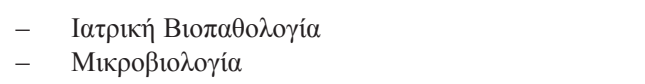 & \\
\hline España & Microbiología y parasitología & Bioquímica clínica \\
\hline \multicolumn{3}{|l|}{ France } \\
\hline Ireland & Microbiology & Chemical pathology \\
\hline Italia & Microbiologia e virologia & Biochimica clinica \\
\hline Ки́ & Мiкроßıороүía & \\
\hline Latvija & Mikrobiologija & \\
\hline \multicolumn{3}{|l|}{ Lietuva } \\
\hline Luxembourg & Microbiologie & Chimie biologique \\
\hline Magyarország & Orvosi mikrobiológia & \\
\hline Malta & Mikrobijologija & Patologija Kimika \\
\hline Nederland & Medische microbiologie & Klinische chemie \\
\hline Österreich & Hygiene und Mikrobiologie & Medizinische und Chemische Labordiagnostik \\
\hline Polska & Mikrobiologia lekarska & \\
\hline \multicolumn{3}{|l|}{ Portugal } \\
\hline Slovenija & Klinična mikrobiologija & Medicinska biokemija \\
\hline Slovensko & Klinická mikrobiológia & Klinická biochémia \\
\hline Suomi/Finland & Kliininen mikrobiologia/Klinisk mikrobiologi & Kliininen kemia/Klinisk kemi \\
\hline Sverige & Klinisk bakteriologi & Klinisk kemi \\
\hline United Kingdom & Medical microbiology and virology & Chemical pathology \\
\hline
\end{tabular}




\begin{tabular}{|c|c|c|}
\hline Stat & $\begin{array}{l}\text { Immunologi } \\
\text { Utdanningens korteste varighet: fire år }\end{array}$ & $\begin{array}{c}\text { Torakskirurgi } \\
\text { Utdanningens korteste varighet: fem år }\end{array}$ \\
\hline & Betegnelse & Betegnelse \\
\hline Belgique/België/ Belgien & & Chirurgie thoracique/Heelkunde op de thorax $(*)$ \\
\hline Česká republika & Alergologie a klinická imunologie & Kardiochirurgie \\
\hline Danmark & Klinisk immunologi & Thoraxkirurgi eller brysthulens kirurgiske sygdomme \\
\hline Deutschland & & Thoraxchirurgie \\
\hline Eesti & & Torakaalkirurgia \\
\hline 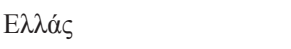 & & 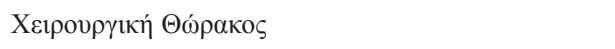 \\
\hline España & Immunología & Cirugía torácica \\
\hline France & & Chirurgie thoracique et cardiovasculaire \\
\hline Ireland & Immunology (clinical and laboratory) & Thoracic surgery \\
\hline Italia & & $\begin{array}{ll}- & \text { Chirurgia toracica } \\
- & \text { Cardiochirurgia }\end{array}$ \\
\hline Kv́ $\pi \rho \circ \varsigma$ & 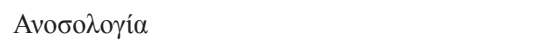 & 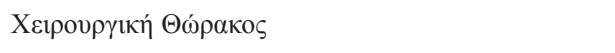 \\
\hline Latvija & Imunoloğija & Torakālā ķ̧irurǵija \\
\hline Lietuva & & Krūtinės chirurgija \\
\hline Luxembourg & Immunologie & Chirurgie thoracique \\
\hline Magyarország & Allergológia és klinikai immunológia & Mellkassebészet \\
\hline Malta & Immunologija & Kirurg̈ija Kardjo-Toraċika \\
\hline Nederland & & Cardio-thoracale chirurgie \\
\hline Österreich & Immunologie & \\
\hline Polska & Immunologia kliniczna & Chirurgia klatki piersiowej \\
\hline Portugal & & Cirurgia cardiotorácica \\
\hline Slovenija & & Torakalna kirurgija \\
\hline Slovensko & Klinická imunológia a alergológia & Hrudníková chirurgia \\
\hline Suomi/Finland & & Sydän-ja rintaelinkirurgia/Hjärt- och thoraxkirurgi \\
\hline Sverige & Klinisk immunologi & Thoraxkirurgi \\
\hline United Kingdom & Immunology & Cardo-thoracic surgery \\
\hline
\end{tabular}

Opphevingsdatoer i henhold til artikkel 27 nr. 3:

(*) 1. januar 1983 


\begin{tabular}{|c|c|c|}
\hline \multirow{2}{*}{ Stat } & $\begin{array}{l}\text { Barnekirurgi } \\
\text { Utdanningens korteste varighet: fem år }\end{array}$ & $\begin{array}{c}\text { Karkirurgi } \\
\text { Utdanningens korteste varighet: fem år }\end{array}$ \\
\hline & Betegnelse & Betegnelse \\
\hline Belgique/België/ Belgien & & Chirurgie des vaisseaux/Bloedvatenheelkunde $\left(^{*}\right)$ \\
\hline Česká republika & Dětská chirurgie & Cévní chirurgie \\
\hline Danmark & & Karkirurgi eller kirurgiske blodkarsygdomme \\
\hline Deutschland & Kinderchirurgie & Gefäßchirurgie \\
\hline Eesti & Lastekirurgia & Kardiovaskulaarkirurgia \\
\hline E $\lambda \lambda a ́ s$ & 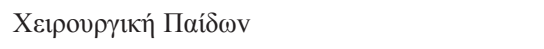 & 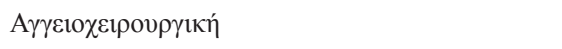 \\
\hline España & Cirugía pediátrica & Angiología y cirugía vascular \\
\hline France & Chirurgie infantile & Chirurgie vasculaire \\
\hline Ireland & Paediatric surgery & \\
\hline Italia & Chirurgia pediatrica & Chirurgia vascolare \\
\hline Ки́лроs & 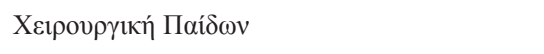 & 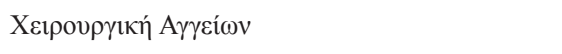 \\
\hline Latvija & Bērnu ķirurğija & Asinsvadu ķirurǵija \\
\hline Lietuva & Vaikų chirurgija & Kraujagyslių chirurgija \\
\hline Luxembourg & Chirurgie pédiatrique & Chirurgie vasculaire \\
\hline Magyarország & Gyermeksebészet & Érsebészet \\
\hline Malta & Kirurgija Pedjatrika & Kirurgija Vaskolari \\
\hline \multicolumn{3}{|l|}{ Nederland } \\
\hline Österreich & Kinderchirurgie & \\
\hline Polska & Chirurgia dziecięca & Chirurgia naczyniowa \\
\hline Portugal & Cirurgia pediátrica & Cirurgia vascular \\
\hline Slovenija & & Kardiovaskularna kirurgija \\
\hline Slovensko & Detská chirurgia & Cievna chirurgia \\
\hline Suomi/Finland & Lastenkirurgia/Barnkirurgi & Verisuonikirurgia/Kärlkirurgi \\
\hline Sverige & Barn- och ungdomskirurgi & \\
\hline United Kingdom & Paediatric surgery & \\
\hline
\end{tabular}

Opphevingsdatoer i henhold til artikkel 27 nr. 3:

(*) 1. januar 1983 


\begin{tabular}{|c|c|c|}
\hline \multirow{2}{*}{ Stat } & $\begin{array}{c}\text { Hjertesykdommer } \\
\text { Utdanningens korteste varighet: fire år }\end{array}$ & $\begin{array}{c}\text { Fordøyelsessykdommer } \\
\text { Utdanningens korteste varighet: fire år }\end{array}$ \\
\hline & Betegnelse & Betegnelse \\
\hline Belgique/België/ Belgien & Cardiologie & Gastro-entérologie/Gastro-enterologie \\
\hline Česká republika & Kardiologie & Gastroenterologie \\
\hline Danmark & Kardiologi & $\begin{array}{l}\text { Medicinsk gastroenterologi eller medicinske } \\
\text { mavetarmsygdomme }\end{array}$ \\
\hline Deutschland & Innere Medizin und Schwerpunkt Kardiologie & Innere Medizin und Schwerpunkt Gastroenterologie \\
\hline Eesti & Kardioloogia & Gastroenteroloogia \\
\hline 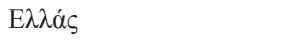 & 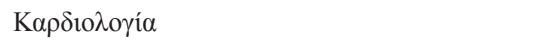 & 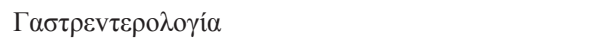 \\
\hline España & Cardiología & Aparato digestivo \\
\hline France & Pathologie cardio-vasculaire & Gastro-entérologie et hépatologie \\
\hline Ireland & Cardiology & Gastro-enterology \\
\hline Italia & Cardiologia & Gastroenterologia \\
\hline Ки́ & 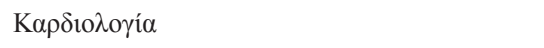 & 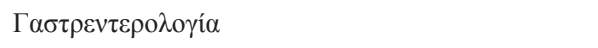 \\
\hline Latvija & Kardiologija & Gastroenterologija \\
\hline Lietuva & Kardiologija & Gastroenterologija \\
\hline Luxembourg & Cardiologie et angiologie & Gastro-enterologie \\
\hline Magyarország & Kardiológia & Gasztroenterológia \\
\hline Malta & Kardjologija & Gastroenterologija \\
\hline Nederland & Cardiologie & Leer van maag-darm-leverziekten \\
\hline \multicolumn{3}{|l|}{ Österreich } \\
\hline Polska & Kardiologia & Gastrenterologia \\
\hline Portugal & Cardiologia & Gastrenterologia \\
\hline Slovenija & & Gastroenterologija \\
\hline Slovensko & Kardiológia & Gastroenterológia \\
\hline Suomi/Finland & Kardiologia/Kardiologi & Gastroenterologia/Gastroenterologi \\
\hline Sverige & Kardiologi & Medicinsk gastroenterologi och hepatologi \\
\hline United Kingdom & Cardiology & Gastro-enterology \\
\hline
\end{tabular}




\begin{tabular}{|c|c|c|}
\hline \multirow{2}{*}{ Stat } & $\begin{array}{c}\text { Revmatologi } \\
\text { Utdanningens korteste varighet: fire år }\end{array}$ & $\begin{array}{l}\text { Generell hematologi } \\
\text { Utdanningens korteste varighet: tre år }\end{array}$ \\
\hline & Betegnelse & Betegnelse \\
\hline Belgique/België/ Belgien & Rhumathologie/reumatologie & \\
\hline Česká republika & Revmatologie & Hematologie a transfúzní lékařství \\
\hline Danmark & Reumatologi & Hæmatologi eller blodsygdomme \\
\hline Deutschland & Innere Medizin und Schwerpunkt Rheumatologie & $\begin{array}{l}\text { Innere Medizin und Schwerpunkt Hämatologie und } \\
\text { Onkologie }\end{array}$ \\
\hline Eesti & Reumatoloogia & Hematoloogia \\
\hline $\mathrm{E} \lambda \lambda \alpha \dot{\alpha}$ & 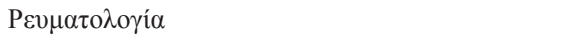 & 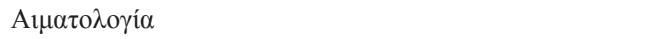 \\
\hline España & Reumatología & Hematología y hemoterapia \\
\hline France & Rhumatologie & \\
\hline Ireland & Rheumatology & Haematology (clinical and laboratory) \\
\hline Italia & Reumatologia & Ematologia \\
\hline 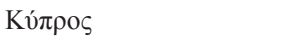 & 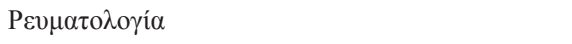 & 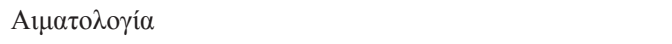 \\
\hline Latvija & Reimatoloǵija & Hematoloǵija \\
\hline Lietuva & Reumatologija & Hematologija \\
\hline Luxembourg & Rhumatologie & Hématologie \\
\hline Magyarország & Reumatológia & Haematológia \\
\hline Malta & Rewmatologija & Ematologija \\
\hline Nederland & Reumatologie & \\
\hline \multicolumn{3}{|l|}{ Österreich } \\
\hline Polska & Reumatologia & Hematologia \\
\hline Portugal & Reumatologia & Imuno-hemoterapia \\
\hline \multicolumn{3}{|l|}{ Slovenija } \\
\hline Slovensko & Reumatológia & Hematológia a transfúziológia \\
\hline Suomi/Finland & Reumatologia/Reumatologi & Kliininen hematologia/Klinisk hematologi \\
\hline Sverige & Reumatologi & Hematologi \\
\hline United Kingdom & Rheumatology & Haematology \\
\hline
\end{tabular}




\begin{tabular}{|c|c|c|}
\hline Stat & $\begin{array}{l}\text { Endokrinologi } \\
\text { Utdanningens korteste varighet: tre år }\end{array}$ & $\begin{array}{l}\text { Fysioterapi } \\
\text { Utdanningens korteste varighet: tre år }\end{array}$ \\
\hline & Betegnelse & Betegnelse \\
\hline Belgique/België/Belgien & & $\begin{array}{l}\text { Médecine physique et réadaptation/Fysische geneeskunde } \\
\text { en revalidatie }\end{array}$ \\
\hline Česká republika & Endokrinologie & Rehabilitační a fyzikální medicína \\
\hline Danmark & $\begin{array}{l}\text { Medicinsk endokrinologi eller medicinske } \\
\text { hormonsygdomme }\end{array}$ & \\
\hline Deutschland & $\begin{array}{l}\text { Innere Medizin und Schwerpunkt Endokrinologie und } \\
\text { Diabetologie }\end{array}$ & Physikalische und Rehabilitative Medizin \\
\hline Eesti & Endokrinoloogia & Taastusravi ja füsiaatria \\
\hline 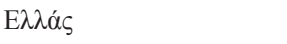 & 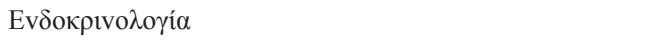 & 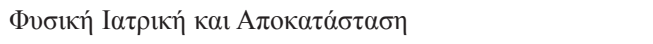 \\
\hline España & Endocrinología y nutrición & Medicina física y rehabilitación \\
\hline France & Endocrinologie, maladies métaboliques & Rééducation et réadaptation fonctionnelles \\
\hline Ireland & Endocrinology and diabetes mellitus & \\
\hline Italia & Endocrinologia e malattie del ricambio & Medicina fisica e riabilitazione \\
\hline Kú $\pi \rho \circ \varsigma$ & 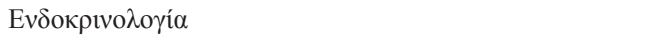 & 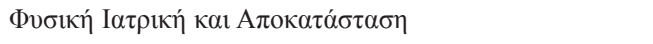 \\
\hline Latvija & Endokrinoloǵija & $\begin{array}{l}\text { Rehabilitologija Fiziskā rehabilitācija } \\
\text { Fizikālā medicīna }\end{array}$ \\
\hline Lietuva & Endokrinologija & Fizinè medicina ir reabilitacija \\
\hline Luxembourg & $\begin{array}{l}\text { Endocrinologie, maladies du métabolisme et de la } \\
\text { nutrition }\end{array}$ & Rééducation et réadaptation fonctionnelles \\
\hline Magyarország & Endokrinológia & Fizioterápia \\
\hline Malta & Endokrinologija u Dijabete & \\
\hline Nederland & & Revalidatiegeneeskunde \\
\hline Österreich & & Physikalische Medizin \\
\hline Polska & Endokrynologia & Rehabilitacja medyczna \\
\hline Portugal & Endocrinologia & $\begin{array}{ll}- & \text { Fisiatria } \\
\text { - } & \text { Medicina física e de reabilitação }\end{array}$ \\
\hline Slovenija & & Fizikalna in rehabilitacijska medicina \\
\hline Slovensko & Endokrinológia & Fyziatria, balneológia a liečebná rehabilitácia \\
\hline Suomi/Finland & Endokrinologia/Endokrinologi & Fysiatria/Fysiatri \\
\hline Sverige & Endokrina sjukdomar & Rehabiliteringsmedicin \\
\hline United Kingdom & Endocrinology and diabetes mellitus & \\
\hline
\end{tabular}




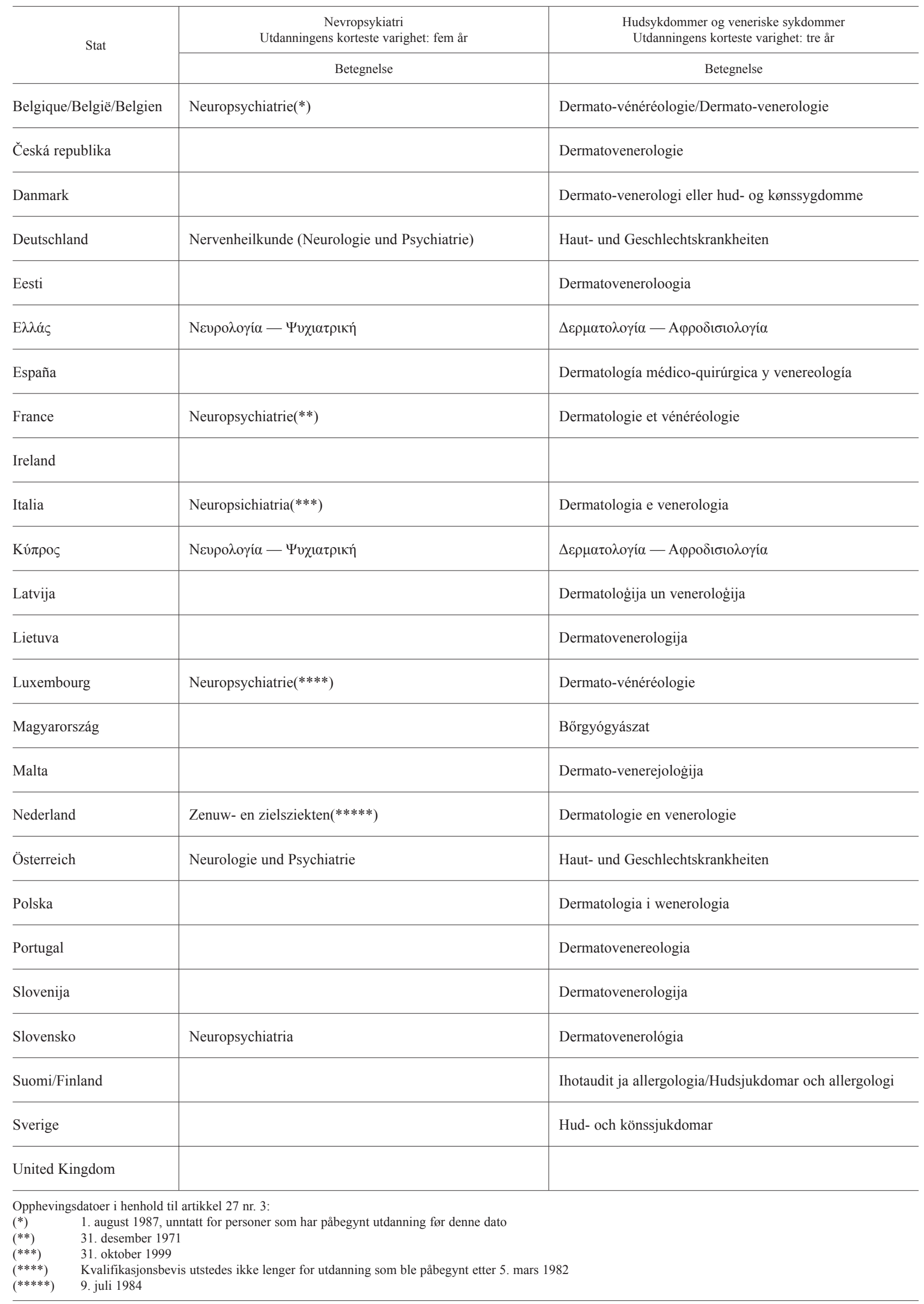




\begin{tabular}{|c|c|c|}
\hline \multirow{2}{*}{ Stat } & $\begin{array}{c}\text { Radiologi } \\
\text { Utdanningens korteste varighet: fire år }\end{array}$ & $\begin{array}{l}\text { Barne- og ungdomspsykiatri } \\
\text { Utdanningens korteste varighet: fire år }\end{array}$ \\
\hline & Betegnelse & Betegnelse \\
\hline Belgique/België/Belgien & & Psychiatrie infanto-juvénile/Kinder- en jeugdpsychiatrie \\
\hline Česká republika & & Dětská a dorostová psychiatrie \\
\hline Danmark & & Børne- og ungdomspsykiatri \\
\hline Deutschland & Radiologie & Kinder- und Jugendpsychiatrie und -psychotherapie \\
\hline \multicolumn{3}{|l|}{ Eesti } \\
\hline 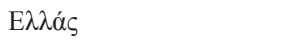 & 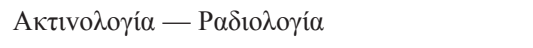 & 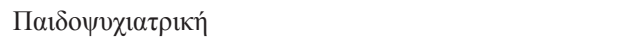 \\
\hline España & Electrorradiología & \\
\hline France & Electro-radiologie $(*)$ & Pédo-psychiatrie \\
\hline Ireland & Radiology & Child and adolescent psychiatry \\
\hline Italia & Radiologia $(* *)$ & Neuropsichiatria infantile \\
\hline Ки́ & & 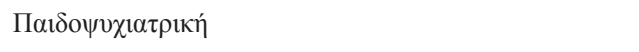 \\
\hline Latvija & & Bērnu psihiatrija \\
\hline Lietuva & & Vaiku ir paauglių psichiatrija \\
\hline Luxembourg & Électroradiologie $(* * *)$ & Psychiatrie infantile \\
\hline Magyarország & Radiológia & Gyermek-és ifjúságpszichiátria \\
\hline \multicolumn{3}{|l|}{ Malta } \\
\hline Nederland & Radiologie $(* * * *)$ & \\
\hline Österreich & Radiologie & \\
\hline Polska & & Psychiatria dzieci i młodzieży \\
\hline Portugal & Radiologia & Pedopsiquiatria \\
\hline Slovenija & & Otroška in mladostniška psihiatrija \\
\hline Slovensko & & Detská psychiatria \\
\hline Suomi/Finland & & Lastenpsykiatria/Barnpsykiatri \\
\hline Sverige & & Barn- och ungdomspsykiatri \\
\hline United Kingdom & & Child and adolescent psychiatry \\
\hline
\end{tabular}

Opphevingsdatoer i henhold til artikkel 27 nr. 3:

(*) 3. desember 1971

(**) 31. oktober 1993

(***) Kvalifikasjonsbevis utstedes ikke lenger for utdanning som ble påbegynt etter 5. mars 1982

$(* * * *) \quad 8$. juli 1984 


\begin{tabular}{|c|c|c|}
\hline \multirow[t]{2}{*}{ Stat } & $\begin{array}{c}\text { Geriatri } \\
\text { Utdanningens korteste varighet: fire år }\end{array}$ & $\begin{array}{l}\text { Nyresykdommer } \\
\text { Utdanningens korteste varighet: fire år }\end{array}$ \\
\hline & Betegnelse & Betegnelse \\
\hline \multicolumn{3}{|c|}{ Belgique/België/ Belgien } \\
\hline Česká republika & Geriatrie & Nefrologie \\
\hline Danmark & Geriatri eller alderdommens sygdomme & Nefrologi eller medicinske nyresygdomme \\
\hline Deutschland & & Innere Medizin und Schwerpunkt Nephrologie \\
\hline Eesti & & Nefroloogia \\
\hline 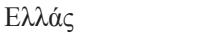 & & 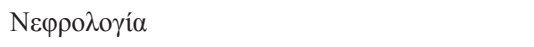 \\
\hline España & Geriatría & Nefrología \\
\hline France & & Néphrologie \\
\hline Ireland & Geriatric medicine & Nephrology \\
\hline Italia & Geriatria & Nefrologia \\
\hline Kú $\pi \rho \circ \varsigma$ & 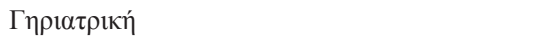 & 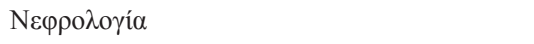 \\
\hline Latvija & & Nefrologiija \\
\hline Lietuva & Geriatrija & Nefrologija \\
\hline Luxembourg & Gériatrie & Néphrologie \\
\hline Magyarország & Geriátria & Nefrológia \\
\hline Malta & Ġerjatrija & Nefrologija \\
\hline Nederland & Klinische geriatrie & \\
\hline \multicolumn{3}{|l|}{ Österreich } \\
\hline Polska & Geriatria & Nefrologia \\
\hline Portugal & & Nefrologia \\
\hline Slovenija & & Nefrologija \\
\hline Slovensko & Geriatria & Nefrológia \\
\hline Suomi/Finland & Geriatria/Geriatri & Nefrologia/Nefrologi \\
\hline Sverige & Geriatrik & Medicinska njursjukdomar (nefrologi) \\
\hline United Kingdom & Geriatrics & Renal medicine \\
\hline
\end{tabular}




\begin{tabular}{|c|c|c|}
\hline \multirow{2}{*}{ Stat } & $\begin{array}{l}\text { Smittsomme sykdommer } \\
\text { Utdanningens korteste varighet: fire år }\end{array}$ & $\begin{array}{l}\text { Samfunnsmedisin } \\
\text { Utdanningens korteste varighet: fire år }\end{array}$ \\
\hline & Betegnelse & Betegnelse \\
\hline \multicolumn{3}{|c|}{ Belgique/België/ Belgien } \\
\hline Česká republika & Infekční lékařství & Hygiena a epidemiologie \\
\hline Danmark & Infektionsmedicin & Samfundsmedicin \\
\hline Deutschland & & Öffentliches Gesundheitswesen \\
\hline Eesti & Infektsioonhaigused & \\
\hline 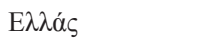 & & 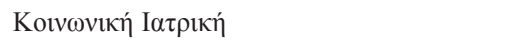 \\
\hline España & & Medicina preventiva y salud pública \\
\hline France & & Santé publique et médecine sociale \\
\hline Ireland & Infectious diseases & Public health medicine \\
\hline Italia & Malattie infettive & Igiene e medicina preventiva \\
\hline 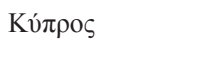 & 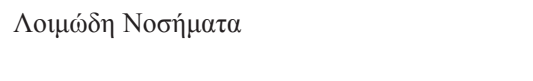 & 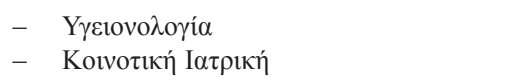 \\
\hline Latvija & Infektologija & \\
\hline Lietuva & Infektologija & \\
\hline Luxembourg & Maladies contagieuses & Santé publique \\
\hline Magyarország & Infektológia & Megelőző orvostan és népegészségtan \\
\hline Malta & Mard Infettiv & Saћћa Pubblika \\
\hline Nederland & & Maatschappij en gezondheid \\
\hline Österreich & & Sozialmedizin \\
\hline Polska & Choroby zakaźne & Zdrowie publiczne, epidemiologia \\
\hline Portugal & Infecciologia & Saúde pública \\
\hline Slovenija & Infektologija & Javno zdravje \\
\hline Slovensko & Infektológia & Verejné zdravotníctvo \\
\hline Suomi/Finland & Infektiosairaudet/Infektionssjukdomar & Terveydenhuolto/Hälsovård \\
\hline Sverige & Infektionssjukdomar & Socialmedicin \\
\hline United Kingdom & Infectious diseases & Public health medicine \\
\hline
\end{tabular}




\begin{tabular}{|c|c|c|}
\hline \multirow{2}{*}{ Stat } & $\begin{array}{l}\text { Farmakologi } \\
\text { Utdanningens korteste varighet: fire år }\end{array}$ & $\begin{array}{c}\text { Arbeidsmedisin } \\
\text { Utdanningens korteste varighet: fire år }\end{array}$ \\
\hline & Betegnelse & Betegnelse \\
\hline Belgique/België/Belgien & & Médecine du travail/Arbeidsgeneeskunde \\
\hline Česká republika & Klinická farmakologie & Pracovní lékařství \\
\hline Danmark & Klinisk farmakologi & Arbejdsmedicin \\
\hline Deutschland & Pharmakologie und Toxikologie & Arbeitsmedizin \\
\hline \multicolumn{3}{|l|}{ Eesti } \\
\hline 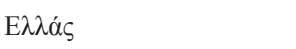 & & 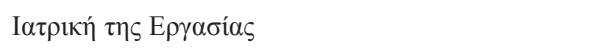 \\
\hline España & Farmacología clínica & Medicina del trabajo \\
\hline France & & Médecine du travail \\
\hline Ireland & Clinical pharmacology and therapeutics & Occupational medicine \\
\hline Italia & Farmacologia & Medicina del lavoro \\
\hline 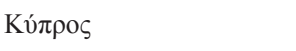 & & 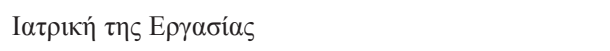 \\
\hline Latvija & & Arodslimības \\
\hline Lietuva & & Darbo medicina \\
\hline Luxembourg & & Médecine du travail \\
\hline Magyarország & Klinikai farmakológia & Foglalkozás-orvostan (üzemorvostan) \\
\hline Malta & Farmakologija Klinika u t-Terapewtika & Medicina Okkupazzjonali \\
\hline Nederland & & $\begin{array}{l}\text { - } \quad \text { Arbeid en gezondheid, bedrijfsgeneeskunde } \\
\text { - } \quad \text { Arbeid en gezondheid, verzekeringsgeneeskunde }\end{array}$ \\
\hline Österreich & Pharmakologie und Toxikologie & Arbeits- und Betriebsmedizin \\
\hline Polska & Farmakologia kliniczna & Medycyna pracy \\
\hline Portugal & & Medicina do trabalho \\
\hline Slovenija & & Medicina dela, prometa in športa \\
\hline Slovensko & Klinická farmakológia & Pracovné lekárstvo \\
\hline Suomi/Finland & $\begin{array}{l}\text { Kliininen farmakologia ja lääkehoito/Klinisk farmakologi } \\
\text { och läkemedelsbehandling }\end{array}$ & Työterveyshuolto/Företagshälsovård \\
\hline Sverige & Klinisk farmakologi & Yrkes- och miljömedicin \\
\hline United Kingdom & Clinical pharmacology and therapeutics & Occupational medicine \\
\hline
\end{tabular}




\begin{tabular}{|c|c|c|}
\hline \multirow{2}{*}{ Stat } & $\begin{array}{c}\text { Allergologi } \\
\text { Utdanningens korteste varighet: tre år }\end{array}$ & $\begin{array}{l}\text { Nukleærmedisin } \\
\text { Utdanningens korteste varighet: fire år }\end{array}$ \\
\hline & Betegnelse & Betegnelse \\
\hline Belgique/België/Belgien & & Médecine nucléaire/Nucleaire geneeskunde \\
\hline Česká republika & Alergologie a klinická imunologie & Nukleární medicína \\
\hline Danmark & $\begin{array}{l}\text { Medicinsk allergologi eller medicinske } \\
\text { overfølsomhedssygdomme }\end{array}$ & Klinisk fysiologi og nuklearmedicin \\
\hline Deutschland & & Nuklearmedizin \\
\hline \multicolumn{3}{|l|}{ Eesti } \\
\hline 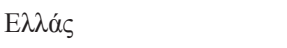 & A $\lambda \lambda \varepsilon \rho \gamma 10 \lambda \circ \gamma i ́ \alpha$ & 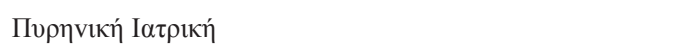 \\
\hline España & Alergología & Medicina nuclear \\
\hline France & & Médecine nucléaire \\
\hline \multicolumn{3}{|l|}{ Ireland } \\
\hline Italia & Allergologia ed immunologia clinica & Medicina nucleare \\
\hline Kú $\pi \rho \circ \varsigma$ & $\mathrm{A} \lambda \lambda \varepsilon \rho \gamma 10 \lambda \circ \gamma^{i} \alpha$ & 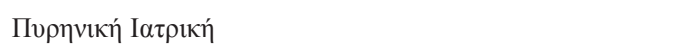 \\
\hline Latvija & Alergologijija & \\
\hline Lietuva & Alergologija ir klinikinė imunologija & \\
\hline Luxembourg & & Médecine nucléaire \\
\hline Magyarország & Allergológia és klinikai immunológia & Nukleáris medicina (izotóp diagnosztika) \\
\hline Malta & & Medicina Nukleari \\
\hline Nederland & Allergologie en inwendige geneeskunde & Nucleaire geneeskunde \\
\hline Österreich & & Nuklearmedizin \\
\hline Polska & Alergologia & Medycyna nuklearna \\
\hline Portugal & Imuno-alergologia & Medicina nuclear \\
\hline Slovenija & & Nuklearna medicina \\
\hline Slovensko & Klinická imunológia a alergológia & Nukleárna medicína \\
\hline Suomi/Finland & & $\begin{array}{l}\text { Kliininen fysiologia ja isotooppilääketiede/Klinisk fysiologi } \\
\text { och nukleärmedicin }\end{array}$ \\
\hline Sverige & Allergisjukdomar & Nukleärmedicin \\
\hline United Kingdom & & Nuclear medicine \\
\hline
\end{tabular}




\begin{tabular}{|c|c|}
\hline \multirow{2}{*}{ Stat } & \multirow[t]{2}{*}{$\begin{array}{l}\text { Kjevekirurgi (medisinsk grunnutdanning) } \\
\text { Utdanningens korteste varighet: fem år }\end{array}$} \\
\hline & \\
\hline \multicolumn{2}{|c|}{ Belgique/België/ Belgien } \\
\hline Česká republika & Maxilofaciální chirurgie \\
\hline \multicolumn{2}{|l|}{ Danmark } \\
\hline \multicolumn{2}{|l|}{ Deutschland } \\
\hline \multicolumn{2}{|l|}{ Eesti } \\
\hline \multicolumn{2}{|l|}{ 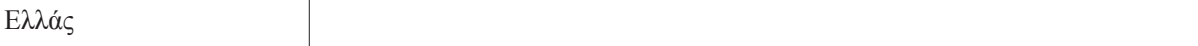 } \\
\hline España & Cirugía oral y maxilofacial \\
\hline France & Chirurgie maxillo-faciale et stomatologie \\
\hline \multicolumn{2}{|l|}{ Ireland } \\
\hline Italia & Chirurgia maxillo-facciale \\
\hline \multicolumn{2}{|l|}{ 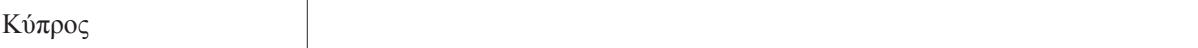 } \\
\hline Latvija & Mutes, sejas un žokḷu ķirurǵija \\
\hline Lietuva & Veido ir žandikaulių chirurgija \\
\hline Luxembourg & Chirurgie maxillo-faciale \\
\hline Magyarország & Szájsebészet \\
\hline \multicolumn{2}{|l|}{ Malta } \\
\hline \multicolumn{2}{|l|}{ Nederland } \\
\hline Österreich & Mund- Kiefer- und Gesichtschirurgie \\
\hline Polska & Chirurgia szczekowo-twarzowa \\
\hline Portugal & Cirurgia maxilo-facial \\
\hline Slovenija & Maxilofaciálna kirurgija \\
\hline Slovensko & Maxilofaciálna chirurgia \\
\hline \multicolumn{2}{|l|}{ Suomi/Finland } \\
\hline \multicolumn{2}{|l|}{ Sverige } \\
\hline United Kingdom & \\
\hline
\end{tabular}




\begin{tabular}{|c|c|}
\hline \multirow[t]{2}{*}{ Stat } & $\begin{array}{l}\text { Biologisk hematologi } \\
\text { Utdanningens korteste varighet: fire år }\end{array}$ \\
\hline & Betegnelse \\
\hline \multicolumn{2}{|c|}{ Belgique/België/Belgien } \\
\hline \multicolumn{2}{|l|}{ Česká republika } \\
\hline Danmark & Klinisk blodtypeserologi(*) \\
\hline \multicolumn{2}{|l|}{ Deutschland } \\
\hline \multicolumn{2}{|l|}{ Eesti } \\
\hline \multicolumn{2}{|l|}{ 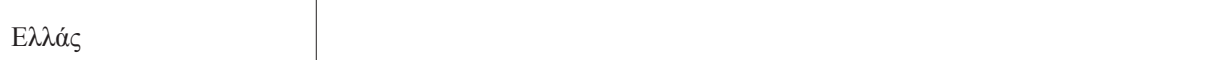 } \\
\hline \multicolumn{2}{|l|}{ España } \\
\hline France & Hématologie \\
\hline \multicolumn{2}{|l|}{ Ireland } \\
\hline \multicolumn{2}{|l|}{ Italia } \\
\hline \multicolumn{2}{|l|}{ Kú $\pi \rho \circ \varsigma$} \\
\hline \multicolumn{2}{|l|}{ Latvija } \\
\hline \multicolumn{2}{|l|}{ Lietuva } \\
\hline Luxembourg & Hématologie biologique \\
\hline \multicolumn{2}{|l|}{ Magyarország } \\
\hline \multicolumn{2}{|l|}{ Malta } \\
\hline \multicolumn{2}{|l|}{ Nederland } \\
\hline \multicolumn{2}{|l|}{ Österreich } \\
\hline \multicolumn{2}{|l|}{ Polska } \\
\hline Portugal & Hematologia clinica \\
\hline \multicolumn{2}{|l|}{ Slovenija } \\
\hline \multicolumn{2}{|l|}{ Slovensko } \\
\hline \multicolumn{2}{|l|}{ Suomi/Finland } \\
\hline \multicolumn{2}{|l|}{ Sverige } \\
\hline United Kingdom & \\
\hline
\end{tabular}




\begin{tabular}{|c|c|c|}
\hline \multirow{2}{*}{ Stat } & $\begin{array}{l}\text { Stomatologi } \\
\text { Utdanningens korteste varighet: tre år }\end{array}$ & $\begin{array}{l}\text { Dermatologi } \\
\text { Utdanningens korteste varighet: fire år }\end{array}$ \\
\hline & Betegnelse & Betegnelse \\
\hline \multicolumn{3}{|c|}{ Belgique/België/Belgien } \\
\hline \multicolumn{3}{|l|}{ Česká republika } \\
\hline \multicolumn{3}{|l|}{ Danmark } \\
\hline \multicolumn{3}{|l|}{ Deutschland } \\
\hline \multicolumn{3}{|l|}{ Eesti } \\
\hline \multicolumn{3}{|l|}{ 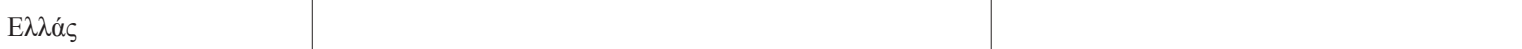 } \\
\hline España & Estomatología & \\
\hline France & Stomatologie & \\
\hline Ireland & & Dermatology \\
\hline Italia & Odontostomatologia $(*)$ & \\
\hline \multicolumn{3}{|l|}{ 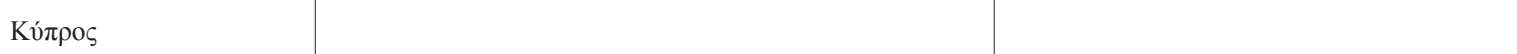 } \\
\hline \multicolumn{3}{|l|}{ Latvija } \\
\hline \multicolumn{3}{|l|}{ Lietuva } \\
\hline Luxembourg & Stomatologie & \\
\hline \multicolumn{3}{|l|}{ Magyarország } \\
\hline Malta & & Dermatologija \\
\hline \multicolumn{3}{|l|}{ Nederland } \\
\hline \multicolumn{3}{|l|}{ Österreich } \\
\hline \multicolumn{3}{|l|}{ Polska } \\
\hline Portugal & Estomatologia & \\
\hline \multicolumn{3}{|l|}{ Slovenija } \\
\hline \multicolumn{3}{|l|}{ Slovensko } \\
\hline \multicolumn{3}{|l|}{ Suomi/Finland } \\
\hline \multicolumn{3}{|l|}{ Sverige } \\
\hline United Kingdom & & Dermatology \\
\hline
\end{tabular}

Opphevingsdatoer i henhold til artikkel 27 nr. 3:

(*) 31. desember 1994 


\begin{tabular}{|c|c|c|}
\hline \multirow{2}{*}{ Stat } & $\begin{array}{c}\text { Venerologi } \\
\text { Utdanningens korteste varighet: fire år }\end{array}$ & $\begin{array}{l}\text { Tropemedisin } \\
\text { Utdanningens korteste varighet: fire å }\end{array}$ \\
\hline & Betegnelse & Betegnelse \\
\hline \multicolumn{3}{|c|}{ Belgique/België/Belgien } \\
\hline \multicolumn{3}{|l|}{ Česká republika } \\
\hline \multicolumn{3}{|l|}{ Danmark } \\
\hline \multicolumn{3}{|l|}{ Deutschland } \\
\hline \multicolumn{3}{|l|}{ Eesti } \\
\hline \multicolumn{3}{|l|}{ 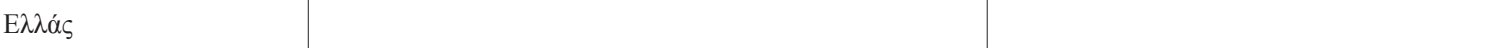 } \\
\hline \multicolumn{3}{|l|}{ España } \\
\hline \multicolumn{3}{|l|}{ France } \\
\hline Ireland & Genito-urinary medicine & Tropical medicine \\
\hline Italia & & Medicina tropicale \\
\hline \multicolumn{3}{|l|}{ 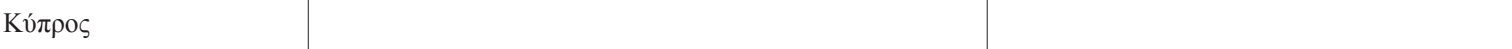 } \\
\hline \multicolumn{3}{|l|}{ Latvija } \\
\hline \multicolumn{3}{|l|}{ Lietuva } \\
\hline \multicolumn{3}{|l|}{ Luxembourg } \\
\hline Magyarország & & Trópusi betegségek \\
\hline Malta & Medic̈ina Uro-ġenetali & \\
\hline \multicolumn{3}{|l|}{ Nederland } \\
\hline Österreich & & Spezifische Prophylaxe und Tropenhygiene \\
\hline Polska & & Medycyna transportu \\
\hline Portugal & & Medicina tropical \\
\hline \multicolumn{3}{|l|}{ Slovenija } \\
\hline Slovensko & & Tropická medicína \\
\hline \multicolumn{3}{|l|}{ Suomi/Finland } \\
\hline \multicolumn{3}{|l|}{ Sverige } \\
\hline United Kingdom & Genito-urinary medicine & Tropical medicine \\
\hline
\end{tabular}




\begin{tabular}{|c|c|c|}
\hline \multirow{2}{*}{ Stat } & $\begin{array}{l}\text { Gastroenterologisk kirurgi } \\
\text { Utdanningens korteste varighet: fem år }\end{array}$ & $\begin{array}{l}\text { Akuttmedisin } \\
\text { Utdanningens korteste varighet: fem år }\end{array}$ \\
\hline & Betegnelse & Betegnelse \\
\hline Belgique/België/Belgien & Chirurgie abdominale/Heelkunde op het abdomen(*) & \\
\hline Česká republika & & $\begin{array}{ll}\text { - } & \text { Traumatologie } \\
\text { - } & \text { Urgentní medicína }\end{array}$ \\
\hline Danmark & $\begin{array}{l}\text { Kirurgisk gastroenterologi eller kirurgiske mave- } \\
\text { tarmsygdomme }\end{array}$ & \\
\hline Deutschland & Visceralchirurgie & \\
\hline \multicolumn{3}{|l|}{ Eesti } \\
\hline \multicolumn{3}{|l|}{ 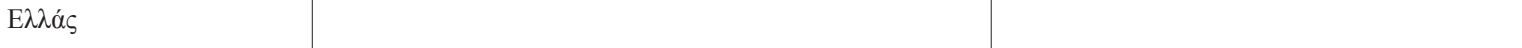 } \\
\hline España & Cirugía del aparato digestivo & \\
\hline France & Chirurgie viscérale et digestive & \\
\hline Ireland & & Emergency medicine \\
\hline Italia & Chirurgia dell'apparato digerente & \\
\hline \multicolumn{3}{|l|}{ 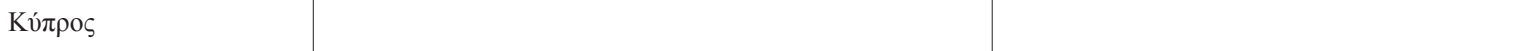 } \\
\hline \multicolumn{3}{|l|}{ Latvija } \\
\hline Lietuva & Abdominalinè chirurgija & \\
\hline Luxembourg & Chirurgie gastro-entérologique & \\
\hline Magyarország & & Traumatológia \\
\hline Malta & & Medic̈ina tal-Aćcidenti u 1-Emerg̉enza \\
\hline \multicolumn{3}{|l|}{ Nederland } \\
\hline \multicolumn{3}{|l|}{ Österreich } \\
\hline Polska & & Medycyna ratunkowa \\
\hline \multicolumn{3}{|l|}{ Portugal } \\
\hline Slovenija & Abdominalna kirurgija & \\
\hline Slovensko & Gastroenterologická chirurgia & $\begin{array}{l}\text { - Úrazová chirurgia } \\
\text { - } \quad \text { Urgentná medicína }\end{array}$ \\
\hline Suomi/Finland & Gastroenterologinen kirurgia/Gastroenterologisk kirurgi & \\
\hline \multicolumn{3}{|l|}{ Sverige } \\
\hline United Kingdom & & Accident and emergency medicine \\
\hline
\end{tabular}

Opphevingsdatoer i henhold til artikkel 27 nr. 3:

(*) 1. januar 1983 


\begin{tabular}{|c|c|c|}
\hline \multirow[t]{2}{*}{ Stat } & $\begin{array}{l}\text { Klinisk nevrofysiologi } \\
\text { Utdanningens korteste varighet: fire år }\end{array}$ & $\begin{array}{c}\text { Kjevekirurgi og munnhulesykdommer (grunnutdanning for leger } \\
\text { og tannleger) }\left({ }^{(}\right) \\
\text {Utdanningens korteste varighet: fire år }\end{array}$ \\
\hline & Betegnelse & Betegnelse \\
\hline Belgique/België/Belgien & & $\begin{array}{l}\text { Stomatologie et chirurgie orale et maxillo-faciale/ } \\
\text { Stomatologie en mond-, kaak- en aangezichtschirurgie }\end{array}$ \\
\hline \multicolumn{3}{|l|}{ Česká republika } \\
\hline Danmark & Klinisk neurofysiologi & \\
\hline Deutschland & & Mund-, Kiefer- und Gesichtschirurgie \\
\hline \multicolumn{3}{|l|}{ Eesti } \\
\hline \multicolumn{3}{|l|}{ 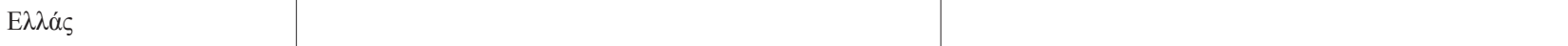 } \\
\hline España & Neurofisiología clínica & \\
\hline \multicolumn{3}{|l|}{ France } \\
\hline Ireland & Clinical neurophysiology & Oral and maxillo-facial surgery \\
\hline \multicolumn{3}{|l|}{ Italia } \\
\hline Ки́ $\pi \rho \circ \varsigma$ & & 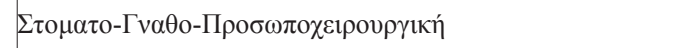 \\
\hline \multicolumn{3}{|l|}{ Latvija } \\
\hline \multicolumn{3}{|l|}{ Lietuva } \\
\hline Luxembourg & & Chirurgie dentaire, orale et maxillo-faciale \\
\hline Magyarország & & Arc-állcsont-szájsebészet \\
\hline Malta & Newrofiżjologija Klinika & Kirurgija tal-ghadam tal-wic̀c \\
\hline \multicolumn{3}{|l|}{ Nederland } \\
\hline \multicolumn{3}{|l|}{ Österreich } \\
\hline \multicolumn{3}{|l|}{ Polska } \\
\hline \multicolumn{3}{|l|}{ Portugal } \\
\hline \multicolumn{3}{|l|}{ Slovenija } \\
\hline \multicolumn{3}{|l|}{ Slovensko } \\
\hline Suomi/Finland & Kliininen neurofysiologia/Klinisk neurofysiologi & Suu- ja leukakirurgia/Oral och maxillofacial kirurgi \\
\hline Sverige & Klinisk neurofysiologi & \\
\hline United Kingdom & Clinical neurophysiology & Oral and maxillo-facial surgery \\
\hline
\end{tabular}


5.1.4. Kvalifikasjonsbevis - allmennmedisin

\begin{tabular}{|c|c|c|c|}
\hline Stat & Kvalifikasjonsbevis & Yrkestittel & Referansedato \\
\hline België/Belgique/Belgien & $\begin{array}{l}\text { Ministerieel erkenningsbesluit } \\
\text { van huisarts/Arrêté ministériel } \\
\text { d'agrément de médecin généraliste }\end{array}$ & Huisarts/Médecin généraliste & 31. desember 1994 \\
\hline Česká republika & $\begin{array}{l}\text { Diplom o specializaci «všeobecné } \\
\text { lékařství» }\end{array}$ & Všeobecný lékař & 1. mai 2004 \\
\hline Danmark & $\begin{array}{l}\text { Tilladelse til at anvende betegnelsen } \\
\text { alment praktiserende læge/ } \\
\text { Speciallægel i almen medicin }\end{array}$ & $\begin{array}{l}\text { Almen praktiserende læge/ } \\
\text { Speciallæge i almen medicin }\end{array}$ & 31. desember 1994 \\
\hline Deutschland & $\begin{array}{l}\text { Zeugnis über die spezifische } \\
\text { Ausbildung in der Allgemeinmedizin }\end{array}$ & $\begin{array}{l}\text { Facharzt/Fachärztin } \quad \text { für } \\
\text { Allgemeinmedizin }\end{array}$ & 31. desember 1994 \\
\hline Eesti & Diplom peremeditsiini erialal & Perearst & 1. mai 2004 \\
\hline 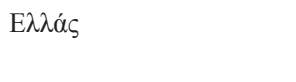 & 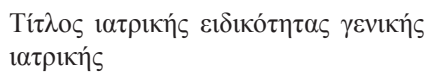 & 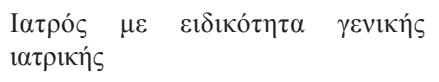 & 31. desember 1994 \\
\hline España & $\begin{array}{l}\text { Título de especialista en medicina } \\
\text { familiar y comunitaria }\end{array}$ & $\begin{array}{l}\text { Especialista en medicina familiar y } \\
\text { comunitaria }\end{array}$ & 31. desember 1994 \\
\hline France & $\begin{array}{l}\text { Diplôme d'Etat de docteur en } \\
\text { médecine (avec document annexé } \\
\text { attestant la formation spécifique en } \\
\text { médecine générale) }\end{array}$ & $\begin{array}{l}\text { Médecin qualifié en médecine } \\
\text { générale }\end{array}$ & 31. desember 1994 \\
\hline Ireland & $\begin{array}{l}\text { Certificate of specific qualifications } \\
\text { in general medical practice }\end{array}$ & General medical practitioner & 31. desember 1994 \\
\hline Italia & $\begin{array}{l}\text { Attestato di formazione specifica in } \\
\text { medicina generale }\end{array}$ & Medico di medicina generale & 31. desember 1994 \\
\hline Kú $\pi \rho \circ$ & 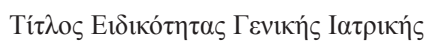 & 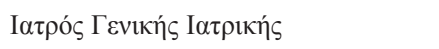 & 1. mai 2004 \\
\hline Latvija & Ģimenes ārsta sertifikāts & Ģimenes (vispārējās prakses) ārsts & 1. mai 2004 \\
\hline Lietuva & $\begin{array}{l}\text { Šeimos gydytojo rezidentūros } \\
\text { pažymèjimas }\end{array}$ & Šeimos medicinos gydytojas & 1. mai 2004 \\
\hline Luxembourg & $\begin{array}{l}\text { Diplôme de formation spécifique en } \\
\text { medicine générale }\end{array}$ & Médecin généraliste & 31. desember 1994 \\
\hline Magyarország & $\begin{array}{l}\text { Háziorvostan } \quad \text { szakorvosa } \\
\text { bizonyítvány }\end{array}$ & Háziorvostan szakorvosa & 1. mai 2004 \\
\hline Malta & Tabib tal-familja & Medic̈ina tal-familja & 1. mai 2004 \\
\hline Nederland & $\begin{array}{l}\text { Certificaat van inschrijving in het } \\
\text { register van erkende huisartsen } \\
\text { van de Koninklijke Nederlandsche } \\
\text { Maatschappij tot bevordering der } \\
\text { geneeskunst }\end{array}$ & Huisarts & 31. desember 1994 \\
\hline Österreich & Arzt für Allgemeinmedizin & Arzt für Allgemeinmedizin & 31. desember 1994 \\
\hline Polska & $\begin{array}{l}\text { Diplôme: Dyplom uzyskania tytułu } \\
\text { specjalisty w dziedzinie medycyny } \\
\text { rodzinnej }\end{array}$ & $\begin{array}{l}\text { Specjalista w dziedzinie medycyny } \\
\text { rodzinnej }\end{array}$ & 1. mai 2004 \\
\hline
\end{tabular}




\begin{tabular}{|c|c|c|c|}
\hline Stat & Kvalifikasjonsbevis & Yrkestittel & Referansedato \\
\hline Portugal & $\begin{array}{l}\text { Diploma do internato complementar } \\
\text { de clínica geral }\end{array}$ & Assistente de clínica geral & 31. desember 1994 \\
\hline Slovenija & $\begin{array}{l}\text { Potrdilo o opravljeni specializaciji iz } \\
\text { družinske medicine }\end{array}$ & $\begin{array}{l}\text { Specialist družinske medicine/ } \\
\text { Specialistka družinske medicine }\end{array}$ & 1. mai 2004 \\
\hline Slovensko & $\begin{array}{l}\text { Diplom o špecializácii v odbore } \\
\text { «všeobecné lekárstvo» }\end{array}$ & Všeobecný lekár & 1. mai 2004 \\
\hline Suomi/ Finland & $\begin{array}{l}\text { Todistus lääkärin } \\
\text { perusterveyde nhuollo n } \\
\text { lisäkoulutuksesta/Bevis om } \\
\text { tilläggsutbildning av läkare i } \\
\text { primärvård }\end{array}$ & Yleisläkäri/Allmänläkare & 31. desember 1994 \\
\hline Sverige & $\begin{array}{l}\text { Bevis om kompetens som } \\
\text { allmänpraktiserande läkare } \\
\text { (Europaläkare) utfärdat av } \\
\text { Socialstyrelsen }\end{array}$ & $\begin{array}{l}\text { Allmänpraktiserande läkare } \\
\text { (Europaläkare) }\end{array}$ & 31. desember 1994 \\
\hline United Kingdom & $\begin{array}{l}\text { Certificate of prescribed/equivalent } \\
\text { experience }\end{array}$ & General medical practitioner & 31. desember 1994 \\
\hline
\end{tabular}

\section{V.2. SYKEPLEIER MED ANSVAR FOR ALMINNELIG SYKEPLEIE}

\subsubsection{Studieprogram for sykepleiere med ansvar for alminnelig sykepleie}

Studieprogrammet som skal føre til kvalitetsbevis som sykepleier med ansvar for alminnelig sykepleie, skal omfatte følgende to deler:

A. Teoretisk undervisning

a. Sykepleie:

- yrkets art og etikk

- alminnelige prinsipper for helse og sykepleie

- prinsipper for sykepleie i forbindelse med

- allmennmedisin og spesialistmedisin

- generell kirurgi og spesialistkirurgi

- barnepleie og pediatri

- pleie ved svangerskap og fødsel

- psykisk helse og psykiatri

- geriatrisk pleie og geriatri

B. Klinisk undervisning

- Sykepleie i forbindelse med

- allmennmedisin og spesialistmedisin

- generell kirurgi og spesialistkirurgi

- barnepleie og pediatri

- pleie ved svangerskap og fødsel

- psykisk helse og psykiatri

- geriatrisk pleie og geriatri

- hjemmesykepleie b. Grunnleggende fag:

- anatomi og fysiologi

- patolog

- bakteriologi, virologi og parasittologi

- biofysikk, biokjemi og radiologi

- dietetikk

- hygiene:

- forebyggende medisin

- helselære

- farmakolog c. Samfunnsfag:

$$
\begin{array}{ll}
\text { - } & \text { sosiologi } \\
\text { - } & \text { psykologi }
\end{array}
$$

- prinsipper for administrasjon

- prinsipper for undervisning

- sosial- og helselovgivning

- sykepleievirksomhetens juridiske aspekter

Undervisningen i ett eller flere av disse fag kan skje innenfor eller i tilknytning til de øvrige fagene.

Den teoretiske undervisningen skal veies opp mot og samordnes med den kliniske undervisningen på en slik måte at de kunnskaper og ferdigheter som er nevnt i dette vedlegg, kan tilegnes på en passende måte. 
5.2.2. Kvalifikasjonsbevis - sykepleier med ansvar for alminnelig sykepleie

\begin{tabular}{|c|c|c|c|c|}
\hline Stat & Kvalifikasjonsbevis & $\begin{array}{l}\text { Organ som utsteder } \\
\text { kvalifikasjonsbeviset }\end{array}$ & Yrkestittel & Referansedato \\
\hline $\begin{array}{l}\text { België/Belgique/ } \\
\text { Belgien }\end{array}$ & 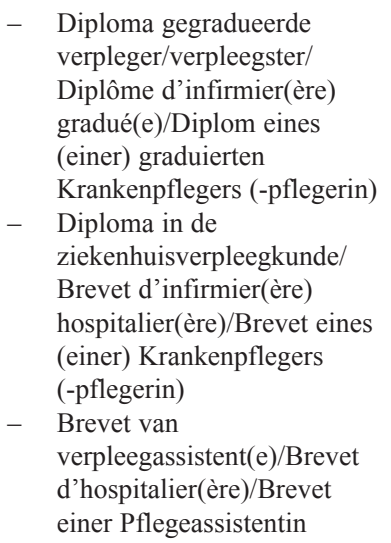 & $\begin{array}{l}\text { _- De erkende } \\
\text { opleidingsinstituten/ } \\
\text { Les établissements } \\
\text { d'enseignement reconnus/ } \\
\text { Die anerkannten } \\
\text { Ausbildungsanstalten } \\
\text { De bevoegde } \\
\text { Examencommissie van de } \\
\text { Vlaamse Gemeenschap/ } \\
\text { Le Jury compétent } \\
\text { d'enseignement de la } \\
\text { Communauté française/Der } \\
\text { zuständige Prüfungsausschüß } \\
\text { der Deutschsprachigen } \\
\text { Gemeinschaft }\end{array}$ & $\begin{array}{ll}- & \text { Hospitalier(ère)/ } \\
\text { Verpleegassistent(e) } \\
-\quad \text { Infirmier(ère) } \\
\text { hospitalier(ère)/ } \\
\text { Ziekenhuisverpleger(- } \\
\text { verpleegster) }\end{array}$ & 29. juni 1979 \\
\hline Česká republika & $\begin{array}{l}\text { 1. Diplom o ukončení studia } \\
\text { ve studijním programu } \\
\text { ošetřovatelství ve studijním } \\
\text { oboru všeobecná sestra } \\
\text { (bakalář, Bc.), accompanied } \\
\text { by the following certificate: } \\
\text { Vysvědčení o státní } \\
\text { závěrečné zkoušce } \\
\text { 2. Diplom o ukončení } \\
\text { studia ve studijním oboru } \\
\text { diplomovaná všeobecná } \\
\text { sestra (diplomovaný } \\
\text { specialista, DiS.), } \\
\text { accompanied by the } \\
\text { following certificate: } \\
\text { Vysvědčení o absolutoriu }\end{array}$ & $\begin{array}{l}\text { 2. Vyšší odborná škola zřízená } \\
\text { nebo uznaná státem }\end{array}$ & $\begin{array}{l}\text { 1. Všeobecná sestra } \\
\text { 2. Všeobecný ošetřovatel }\end{array}$ & 1. mai 2004 \\
\hline Danmark & $\begin{array}{l}\text { Eksamensbevis efter gennemført } \\
\text { sygeplejerskeuddannelse }\end{array}$ & $\begin{array}{l}\text { Sygeplejeskole godkendt af } \\
\text { Undervisningsministeriet }\end{array}$ & Sygeplejerske & 29. juni 1979 \\
\hline Deutschland & $\begin{array}{l}\text { Zeugnis über die staatliche } \\
\text { Prüfung in der Krankenpflege }\end{array}$ & Staatlicher Prüfungsausschuss & $\begin{array}{l}\text { Gesundheits- und } \\
\text { Krankenpflegerin/Gesundheits- } \\
\text { und Krankenpfleger }\end{array}$ & 29. juni 1979 \\
\hline Eesti & Diplom õe erialal & $\begin{array}{l}\text { 1. Tallinna Meditsiinikool } \\
\text { 2. Tartu Meditsiinikool } \\
\text { 3. Kohtla-Järve Meditsiinikool }\end{array}$ & õde & 1. mai 2004 \\
\hline E $\lambda \lambda \alpha \dot{\alpha}$ & 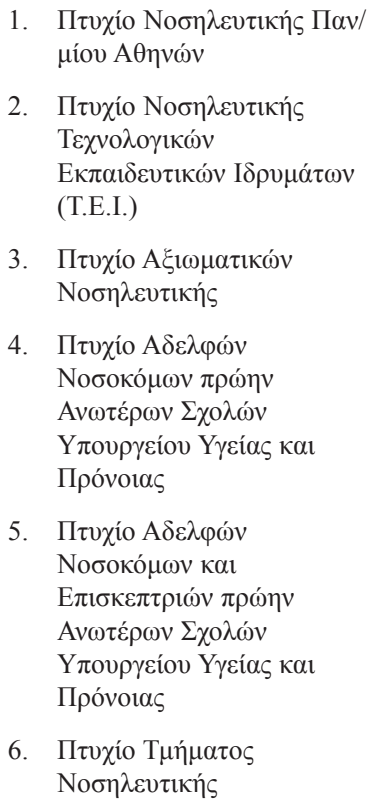 & 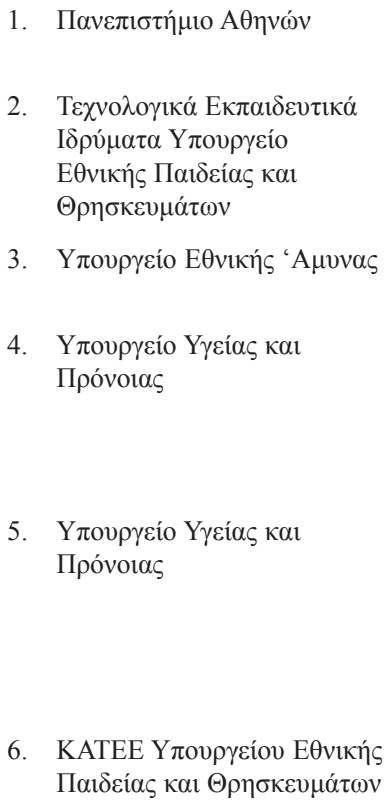 & 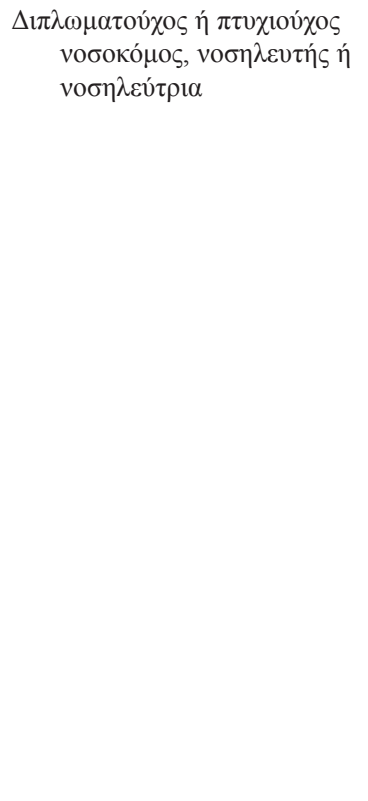 & 1. januar 1981 \\
\hline
\end{tabular}




\begin{tabular}{|c|c|c|c|c|}
\hline España & $\begin{array}{l}\text { Título de Diplomado } \\
\text { universitario en Enfermería }\end{array}$ & $\begin{array}{l}\text { - Ministerio de Educación y } \\
\text { Cultura } \\
\text { - } \quad \text { El rector de una universidad }\end{array}$ & Enfermero/a diplomado/a & 1. januar 1986 \\
\hline France & 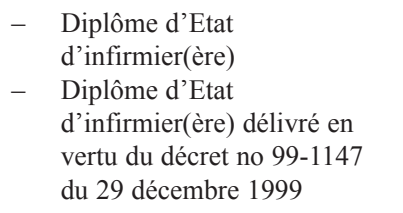 & Le ministère de la santé & Infirmer(ère) & 29. juni 1979 \\
\hline Ireland & $\begin{array}{l}\text { Certificate of Registered General } \\
\text { Nurse }\end{array}$ & $\begin{array}{l}\text { An Bord Altranais (The Nursing } \\
\text { Board) }\end{array}$ & Registered General Nurse & 29. juni 1979 \\
\hline Italia & $\begin{array}{l}\text { Diploma di infermiere } \\
\text { professionale }\end{array}$ & Scuole riconosciute dallo Stato & Infermiere professionale & 29. juni 1979 \\
\hline 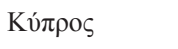 & 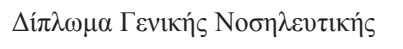 & 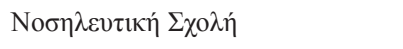 & 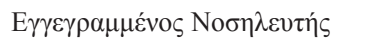 & 1. mai 2004 \\
\hline Latvija & $\begin{array}{l}\text { 1. Diploms par māsas } \\
\text { kvalifikācijas iegūšanu } \\
\text { 2. Māsas diploms }\end{array}$ & $\begin{array}{l}\text { 1. Māsu skolas } \\
\text { 2. niversitātes tipa augstskola } \\
\text { pamatojoties uz Valsts } \\
\text { eksāmenu komisijas lēmumu }\end{array}$ & Māsa & 1. mai 2004 \\
\hline Lietuva & $\begin{array}{l}\text { 1. Aukštojo mokslo diplomas, } \\
\text { nurodantis suteiktą } \\
\text { bendrosios praktikos } \\
\text { slaugytojo profesinę } \\
\text { kvalifikaciją }\end{array}$ & $\begin{array}{l}\text { 1. Universitetas } \\
\text { 2. Kolegija }\end{array}$ & Bendrosios praktikos slaugytojas & 1. mai 2004 \\
\hline Luxembourg & $\begin{array}{l}\text { - Diplôme d'Etat d'infirmier } \\
\text { - } \quad \text { Diplôme d'Etat d'infirmier } \\
\text { hospitalier gradué }\end{array}$ & $\begin{array}{l}\text { Ministère de l'éducation } \\
\text { nationale, de la formation } \\
\text { professionnelle et des sports }\end{array}$ & Infirmier & 29. juni 1979 \\
\hline Magyarország & $\begin{array}{l}\text { 1. Ápoló bizonyítvány } \\
\text { 2. Diplomás ápoló oklevél } \\
\text { 3. Egyetemi okleveles ápoló } \\
\text { oklevél }\end{array}$ & $\begin{array}{l}\text { 1. Iskola } \\
\text { 2. Egyetem/föiskola } \\
\text { 3. Egyetem }\end{array}$ & Ápoló & 1. mai 2004 \\
\hline Malta & $\begin{array}{l}\text { Lawrja jew diploma fl-istudji tal- } \\
\text { infermerija }\end{array}$ & Universita' ta' Malta & $\begin{array}{l}\text { Infermier Registrat tal-Ewwel } \\
\text { Livell }\end{array}$ & 1. mai 2004 \\
\hline Nederland & $\begin{array}{l}\text { 1. Diploma's verpleger } \\
\text { A, verpleegster A, } \\
\text { verpleegkundige A } \\
\text { 2. Diploma verpleegkundige } \\
\text { MBOV (Middelbare } \\
\text { Beroepsopleiding } \\
\text { Verpleegkundige) } \\
\text { 3. Diploma verpleegkundige } \\
\text { HBOV (Hogere } \\
\text { Beroepsopleiding } \\
\text { Verpleegkundige) } \\
\text { 4. Diploma beroepsonderwijs } \\
\text { verpleegkundige - } \\
\text { Kwalificatieniveau } 4 \\
\text { 5. Diploma hogere } \\
\text { beroepsopleiding } \\
\text { verpleegkundige - } \\
\text { Kwalificatieniveau } 5\end{array}$ & $\begin{array}{l}\text { 1. } \begin{array}{l}\text { Door een van overheidswege } \\
\text { benoemde examencommissie }\end{array} \\
\text { 2. } \begin{array}{l}\text { Door een van overheidswege } \\
\text { benoemde examencommissie }\end{array} \\
\text { 3. Door een van overheidswege } \\
\text { benoemde examencommissie }\end{array}$ & Verpleegkundige & 29. juni 1979 \\
\hline
\end{tabular}




\begin{tabular}{|c|c|c|c|c|}
\hline Österreich & $\begin{array}{l}\text { 1. Diplom als «Diplomierte } \\
\text { Gesundheits- und } \\
\text { Krankenschwester, } \\
\text { Diplomierter Gesundheits- } \\
\text { und Krankenpfleger» } \\
\\
\text { 2. Diplom als «Diplomierte } \\
\text { Krankenschwester, } \\
\text { Diplomierter } \\
\text { Krankenpfleger» }\end{array}$ & $\begin{array}{l}\text { 1. Schule für allgemeine } \\
\text { Gesundheits- und } \\
\text { Krankenpflege }\end{array}$ & $\begin{array}{ll}- & \text { Diplomierte } \\
& \text { Krankenschwester } \\
- & \text { Diplomierter Krankenpfleger }\end{array}$ & 1. januar 1994 \\
\hline Polska & $\begin{array}{l}\text { Dyplom ukończenia studiów } \\
\text { wyższych na kierunku } \\
\text { pielegniarstwo z tytułem } \\
\text { «magister pielegniarstwa» }\end{array}$ & $\begin{array}{l}\text { Instytucja prowadząca } \\
\text { kształcenie na poziomie } \\
\text { wyższym uznana przez właściwe } \\
\text { władze } \\
\text { Higher educational institution } \\
\text { recognised by the competent } \\
\text { authorities) }\end{array}$ & Pielegniarka & 1. mai 2004 \\
\hline Portugal & $\begin{array}{l}\text { 1. Diploma do curso de } \\
\text { enfermagem geral } \\
\text { 2. Diploma/carta de curso de } \\
\text { bacharelato em enfermagem }\end{array}$ & $\begin{array}{l}\text { 1. Escolas de Enfermagem } \\
\text { 2. Escolas Superiores de } \\
\text { Enfermagem } \\
\text { 3. Escolas Superiores de } \\
\text { Enfermagem; Escolas } \\
\text { Superiores de Saúde }\end{array}$ & Enfermeiro & 1. januar 1986 \\
\hline Slovenija & $\begin{array}{l}\text { Diploma, s katero se podeljuje } \\
\text { strokovni naslov «diplomirana } \\
\text { medicinska sestra/diplomirani } \\
\text { zdravstvenik» }\end{array}$ & $\begin{array}{l}\text { 1. Univerza } \\
\text { 2. Visoka strokovna šola }\end{array}$ & $\begin{array}{l}\text { Diplomirana medicinska sestra/ } \\
\text { Diplomirani zdravstvenik }\end{array}$ & 1. mai 2004 \\
\hline Slovensko & 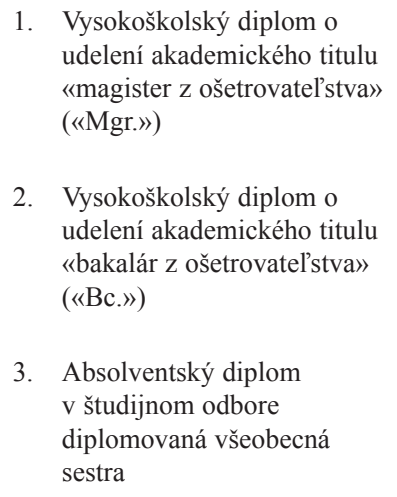 & $\begin{array}{l}\text { 1. Vysoká škola } \\
\text { 2. Vysoká škola } \\
\text { 3. Stredná zdravotnícka škola }\end{array}$ & Sestra & 1. mai 2004 \\
\hline Suomi/ Finland & $\begin{array}{l}\text { 1. Sairaanhoitajan tutkinto/ } \\
\text { Sjukskötarexamen } \\
\text { 2. Sosiaali- ja terveysalan } \\
\text { ammattikorkeakoulututkinto, } \\
\text { sairaanhoitaja (AMK)/ } \\
\text { Yrkeshögskoleexamen inom } \\
\text { hälsovård och det sociala } \\
\text { området, sjukskötare (YH) }\end{array}$ & $\begin{array}{l}\text { 1. Terveydenhuolto- } \\
\text { oppilaitokset/ } \\
\text { Hälsovårdsläroanstalter } \\
\text { 2. Ammattikorkeakoulut/ } \\
\text { Yrkeshögskolor }\end{array}$ & Sairaanhoitaja/Sjukskötare & 1. januar 1994 \\
\hline Sverige & Sjuksköterskeexamen & Universitet eller högskola & Sjuksköterska & 1. januar 1994 \\
\hline United Kingdom & $\begin{array}{l}\text { Statement of Registration as a } \\
\text { Registered General Nurse in part } \\
1 \text { or part } 12 \text { of the register kept } \\
\text { by the United Kingdom Central } \\
\text { Council for Nursing, Midwifery } \\
\text { and Health Visiting }\end{array}$ & Various & $\begin{array}{l}\text { - State Registered Nurse } \\
\text { - } \quad \text { Registered General Nurse }\end{array}$ & 29. juni 1979 \\
\hline
\end{tabular}




\section{V.3. TANNLEGE}

\subsubsection{Studieprogram for tannleger}

Studieprogrammet som skal føre til kvalifikasjonsbevis som tannlege, skal minst omfatte følgende fag. Undervisningen i ett eller flere av disse fagene kan skje innenfor eller i tilknytning til de øvrige fagene.

A. Grunnleggende fag

$$
\begin{aligned}
& \text { - Kjemi } \\
& \text { - Fysikk } \\
& \text { - Biologi }
\end{aligned}
$$

B. Medisinsk-biologiske og allmennmedisinske fag

$$
\begin{array}{ll}
- & \text { Anatomi } \\
- & \text { Embryologi } \\
- & \text { Histologi, herunder cytologi } \\
- & \text { Fysiologi } \\
- & \text { Biokjemi (eller fysiologisk kjemi) } \\
- & \text { Patologisk anatomi } \\
- & \text { Allmenn patologi } \\
- & \text { Farmakologi } \\
- & \text { Mikrobiologi } \\
- & \text { Hygiene } \\
- & \text { Forebyggende medisin og epidemiologi } \\
- & \text { Radiologi } \\
- & \text { Fysioterapi } \\
- & \text { Generell kirurgi } \\
- & \text { Allmennmedisin, herunder pediatri } \\
- & \text { Otorhinolaryngologi (øre-nese- } \\
& \text { halssykdommer) } \\
- & \text { Dermato-venerologi } \\
- & \text { Allmenn psykologi, psykopatologi og } \\
& \text { nevropatologi } \\
- & \text { Anestesiologi } \\
\hline &
\end{array}
$$

\begin{tabular}{|c|c|c|c|c|c|}
\hline Stat & Kvalifikasjonsbevis & $\begin{array}{l}\text { Organ som utsteder } \\
\text { kvalifikasjonsbeviset }\end{array}$ & $\begin{array}{l}\text { Attest som ledsager } \\
\text { kvalifikasjonsbeviset }\end{array}$ & Yrkestittel & Referansedato \\
\hline $\begin{array}{l}\text { België/Belgique/ } \\
\text { Belgien }\end{array}$ & $\begin{array}{l}\text { Diploma van tandarts/ } \\
\text { Diplôme licencié en } \\
\text { science dentaire }\end{array}$ & $\begin{array}{l}\text { - De universiteiten/ } \\
\text { Les universités } \\
\text { - De bevoegde } \\
\text { Examen- commissie } \\
\text { van de Vlaamse } \\
\text { Gemeenschap/Le } \\
\text { Jury compétent } \\
\text { d'enseignement de } \\
\text { la Communauté } \\
\text { française }\end{array}$ & & $\begin{array}{l}\text { Licentiaat in de } \\
\text { tandheelkunde/Licencié } \\
\text { en science dentaire }\end{array}$ & 28. januar 1980 \\
\hline Česká republika & $\begin{array}{lr}\text { Diplom o } & \text { ukončení } \\
\text { studia ve } & \text { studijním } \\
\text { programu zubní lékařství } \\
\text { (doktor } & \text { zubního } \\
\text { lékařství) } & \end{array}$ & $\begin{array}{llll}\begin{array}{l}\text { Lékařská } \\
\text { univerzity }\end{array} & \text { vakulta } & \text { České } \\
\text { republice } & & \end{array}$ & $\begin{array}{l}\text { Vysvědčení o státní } \\
\text { rigorózní zkoušce }\end{array}$ & Zubní lékař & 1. mai 2004 \\
\hline Danmark & $\begin{array}{l}\text { Bevis for } \\
\text { tandlægeeksamen } \\
\text { (odontologisk } \\
\text { kandidateksamen) }\end{array}$ & $\begin{array}{l}\text { Tandlægehøjskolerne, } \\
\text { Sundhedsvidenskabeligt } \\
\text { universitetsfakultet }\end{array}$ & $\begin{array}{l}\text { Autorisation som } \\
\text { tandlæge, udstedt af } \\
\text { Sundhedsstyrelsen }\end{array}$ & Tandlæge & 28. januar 1980 \\
\hline
\end{tabular}

C. Fag som er direkte knyttet til tannlegevirksomhet

- Proteselære

- Tannlegematerialer

- Konserverende tannpleie

- Forebyggende tannpleie

- Anestesi og smertestillende midler i tannpleien

- Spesialkirurgi

- Spesialpatologi

- Klinisk praksis

- Pedodonti

- Kjeveortopedi

- Periodonti

- Odontologisk radiologi

- Bittfunksjonslære

- Yrkesorganisering, -etikk og -lovgivning

- Tannlegevirksomhetens sosiale aspekter

5.3.2. Kvalifikasjonsbevis - grunnutdanning for tannleger 


\begin{tabular}{|c|c|c|c|c|c|}
\hline Stat & Kvalifikasjonsbevis & $\begin{array}{l}\text { Organ som utsteder } \\
\text { kvalifikasjonsbeviset }\end{array}$ & $\begin{array}{l}\text { Attest som ledsager } \\
\text { kvalifikasjonsbeviset }\end{array}$ & Yrkestittel & Referansedato \\
\hline Deutschland & $\begin{array}{l}\text { Zeugnis über die } \\
\text { Zahnärztliche Prüfung }\end{array}$ & Zuständige Behörden & & Zahnarzt & 28. januar 1980 \\
\hline Eesti & $\begin{array}{l}\text { Diplom } \\
\text { hambaarstiteaduse } \\
\text { õppekava läbimise kohta }\end{array}$ & Tartu Ülikool & & Hambaarst & 1. mai 2004 \\
\hline 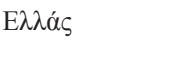 & 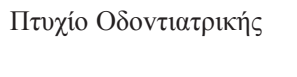 & 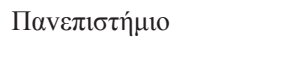 & & 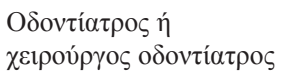 & 1. januar 1981 \\
\hline España & $\begin{array}{l}\text { Título de Licenciado en } \\
\text { Odontología }\end{array}$ & $\begin{array}{lr}\text { El rector de una } \\
\text { universidad }\end{array}$ & & $\begin{array}{l}\text { Licenciado en } \\
\text { odontología }\end{array}$ & 1. januar 1986 \\
\hline France & $\begin{array}{l}\text { Diplôme d'Etat de } \\
\text { docteur en chirurgie } \\
\text { dentaire }\end{array}$ & Universités & & Chirurgien-dentiste & 28. januar 1980 \\
\hline Ireland & $\begin{aligned} &- \text { Bachelor in Dental } \\
& \text { Science (B.Dent. } \\
& \text { Sc.) } \\
&-\quad \text { Bachelor of Dental } \\
& \text { Surgery (BDS) } \\
&-\quad \text { Licentiate in Dental } \\
& \text { Surgery (LDS) }\end{aligned}$ & $\begin{array}{ll}- & \text { Universities } \\
- & \text { Royal College of } \\
& \text { Surgeons in Ireland }\end{array}$ & & $\begin{array}{ll}- & \text { Dentist } \\
- & \text { Dental practitioner } \\
- & \text { Dental surgeon }\end{array}$ & 28. januar 1980 \\
\hline Italia & $\begin{array}{l}\text { Diploma di laurea in } \\
\text { Odontoiatria e Protesi } \\
\text { Dentaria }\end{array}$ & Università & $\begin{array}{l}\text { Diploma di abilitazione } \\
\text { all'esercizio } \\
\text { profella } \\
\text { odontoiatra }\end{array}$ & Odontoiatra & 28. januar 1980 \\
\hline 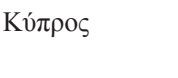 & 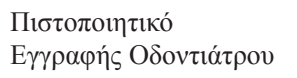 & 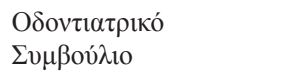 & & 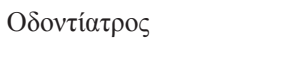 & 1. mai 2004 \\
\hline Latvija & Zobārsta diploms & $\begin{array}{l}\text { Universitātes } \\
\text { augstskola }\end{array}$ & $\begin{array}{l}\text { Rezidenta diploms par } \\
\text { zobārsta pēcdiploma } \\
\text { izglîtības programmas } \\
\text { pabeigšanu, ko } \\
\text { izsniedz universitātes } \\
\text { tipa augstskola un } \\
\text { «Sertifikāts» - } \\
\text { kompetentas iestādes } \\
\text { izsniegts dokuments, } \\
\text { kas apliecina, ka } \\
\text { persona ir nokārtojusi } \\
\text { sertifikācijas eksāmenu } \\
\text { zobārstniecībā }\end{array}$ & Zobārsts & 1. mai 2004 \\
\hline Lietuva & $\begin{array}{lr}\text { Aukštojo } & \text { mokslo } \\
\text { diplomas, } & \text { nurodantis } \\
\text { suteiktą } & \text { gydytojo } \\
\text { odontologo kvalifikaciją }\end{array}$ & Universitetas & $\begin{array}{l}\text { Internatūros } \\
\text { pažymejimas, } \\
\text { nurodantis suteiktą } \\
\text { gydytojo odontologo } \\
\text { profesinę kvalifikaciją }\end{array}$ & Gydytojas odontologas & 1. mai 2004 \\
\hline Luxembourg & $\begin{array}{l}\text { Diplôme d'Etat de } \\
\text { docteur en médecine } \\
\text { dentaire }\end{array}$ & Jury d'examen d'Etat & & Médecin-dentiste & 28. januar 1980 \\
\hline Magyarország & $\begin{array}{l}\text { Fogorvos oklevél (doctor } \\
\text { medicinae dentariae, } \\
\text { röv.: dr. med. dent.) }\end{array}$ & Egyetem & & Fogorvos & 1. mai 2004 \\
\hline
\end{tabular}




\begin{tabular}{|c|c|c|c|c|c|}
\hline Stat & Kvalifikasjonsbevis & $\begin{array}{l}\text { Organ som utsteder } \\
\text { kvalifikasjonsbeviset }\end{array}$ & $\begin{array}{l}\text { Attest som ledsager } \\
\text { kvalifikasjonsbeviset }\end{array}$ & Yrkestittel & Referansedato \\
\hline Malta & $\begin{array}{l}\text { Lawrja fil- Kirurgija } \\
\text { Dentali }\end{array}$ & Universita' ta Malta & & Kirurgu Dentali & 1. mai 2004 \\
\hline Nederland & $\begin{array}{l}\text { Universitair getuigschrift } \\
\text { van een met goed gevolg } \\
\text { afgelegd tandartsexamen }\end{array}$ & Faculteit Tandheelkunde & & Tandarts & 28. januar 1980 \\
\hline Österreich & $\begin{array}{l}\text { Bescheid über die } \\
\text { Verleihung des } \\
\text { akademischen } \\
\text { Grades «Doktor der } \\
\text { Zahnheilkunde» }\end{array}$ & $\begin{array}{l}\text { Medizinische Fakultät } \\
\text { der Universität }\end{array}$ & & Zahnarzt & 1. januar 1994 \\
\hline Polska & $\begin{array}{lr}\text { Dyplom } & \text { ukończenia } \\
\text { studiów } & \text { wyższych } \\
z \quad \text { tytułem } & \text { «lekarz } \\
\text { dentysta» } & \end{array}$ & $\begin{array}{l}\text { 1. Akademia Medyczna, } \\
\text { 2.Uniwersytet } \\
\text { Medyczny, } \\
\text { 3.Collegium Medicum } \\
\text { Uniwersytetu } \\
\text { Jagiellońskiego }\end{array}$ & $\begin{array}{l}\text { Lekarsko - } \\
\text { Dentystyczny } \\
\text { Egzamin Państwowy }\end{array}$ & Lekarz dentysta & 1. mai 2004 \\
\hline Portugal & $\begin{array}{l}\text { Carta de curso de } \\
\text { licenciatura em medicina } \\
\text { dentária }\end{array}$ & $\begin{array}{ll}- & \text { Faculdades } \\
- & \text { Institutos Superiores }\end{array}$ & & Médico dentista & 1. januar 1986 \\
\hline Slovenija & $\begin{array}{l}\text { Diploma, s katero se } \\
\text { podeljuje strokovni } \\
\text { naslov «doktor dentalne } \\
\text { medicine/doktorica } \\
\text { dentalne medicine» }\end{array}$ & - Univerza & $\begin{array}{l}\text { Potrdilo o opravljenem } \\
\text { strokovnem izpitu za } \\
\text { poklic zobozdravnik/ } \\
\text { zobozdravnica }\end{array}$ & $\begin{array}{l}\text { Doktor dentalne } \\
\text { medicine/Doktorica } \\
\text { dentalne medicine }\end{array}$ & 1. mai 2004 \\
\hline Slovensko & $\begin{array}{l}\text { Vysokoškolský diplom } \\
\text { o udelení akademického } \\
\text { titulu «doktor zubného } \\
\text { lekárstva» («MDDr.») }\end{array}$ & - Vysoká škola & & Zubný lekár & 1. mai 2004 \\
\hline Suomi/ Finland & $\begin{array}{l}\text { Hammaslääketieteen } \\
\text { lisensiaatin tutkinto/ } \\
\text { Odontologie } \\
\text { licentiatexamen }\end{array}$ & $\begin{array}{ll}- & \text { Helsingin yliopisto/ } \\
& \text { Helsingfors } \\
\text { universitet }\end{array}$ & $\begin{array}{l}\text { Terveydenhuollon } \\
\text { oikeusturvakeskuksen } \\
\text { päätös käytännön } \\
\text { palvelun } \\
\text { hyväksymisestä/Beslut } \\
\text { av Rättskyddscentralen } \\
\text { för hälsovården om } \\
\text { godkännande av } \\
\text { praktisk tjänstgöring }\end{array}$ & $\begin{array}{l}\text { Hammaslääkäri/ } \\
\text { Tandläkare }\end{array}$ & 1. januar 1994 \\
\hline Sverige & Tandläkarexamen & $\begin{array}{lll}- & \text { Universitetet } & \text { i } \\
& \text { Umeå } & \\
- & \text { Universitetet } & \mathrm{i} \\
& \text { Göteborg } \\
- & \text { Karolinska Institutet } \\
- & \text { Malmö Högskola }\end{array}$ & $\begin{array}{l}\text { Endast för } \\
\text { examensbevis som } \\
\text { erhållits före den } \\
1 \text { juli 1995, ett } \\
\text { utbildningsbevis } \\
\text { som utfärdats av } \\
\text { Socialstyrelsen }\end{array}$ & Tandläkare & 1. januar 1994 \\
\hline United Kingdom & $\begin{array}{l}\text { - Bachelor of Dental } \\
\text { Surgery (BDS or } \\
\text { B.Ch.D.) } \\
-\quad \text { Licentiate in Dental } \\
\text { Surgery }\end{array}$ & $\begin{array}{ll}- & \text { Universities } \\
- & \text { Royal Colleges }\end{array}$ & & $\begin{array}{ll}- & \text { Dentist } \\
- & \text { Dental practitioner } \\
- & \text { Dental surgeon }\end{array}$ & 28. januar 1980 \\
\hline
\end{tabular}


5.3.3. Kvalifikasjonsbevis - tannlege med spesialistutdanning

\begin{tabular}{|c|c|c|c|}
\hline \multicolumn{4}{|c|}{ Kjeveortopedi } \\
\hline Stat & Kvalifikasjonsbevis & Organ som utsteder kvalifikasjonsbeviset & Referansedato \\
\hline België/Belgique/Belgien & $\begin{array}{l}\text { Titre professionnel particulier de dentiste } \\
\text { spécialiste en orthodontie/Bijzondere beroepstitel } \\
\text { van tandarts specialist in de orthodontie }\end{array}$ & $\begin{array}{l}\text { Ministre de la Santé publique/Minister bevoegd } \\
\text { voor Volksgezondheid }\end{array}$ & 27. januar 2005 \\
\hline Danmark & $\begin{array}{l}\text { Bevis for tilladelse til at betegne sig som } \\
\text { specialtandlæge } \mathrm{i} \text { ortodonti }\end{array}$ & Sundhedsstyrelsen & 28. januar 1980 \\
\hline Deutschland & $\begin{array}{l}\text { Fachzahnärztliche Anerkennung für } \\
\text { Kieferorthopädie; }\end{array}$ & Landeszahnärztekammer & 28. januar 1980 \\
\hline Eesti & Residentuuri lõputunnistus ortodontia erialal & Tartu Ülikool & 1. mai 2004 \\
\hline 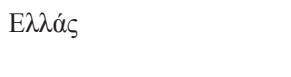 & 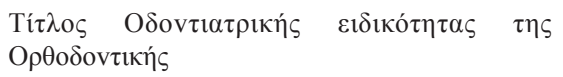 & 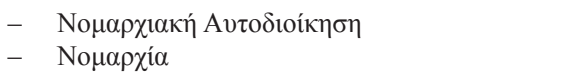 & 1. januar 1981 \\
\hline France & Titre de spécialiste en orthodontie & $\begin{array}{l}\text { Conseil National de l'Ordre des chirurgiens } \\
\text { dentistes }\end{array}$ & 28. januar 1980 \\
\hline Ireland & Certificate of specialist dentist in orthodontics & $\begin{array}{l}\text { Competent authority recognised for this purpose } \\
\text { by the competent minister }\end{array}$ & 28. januar 1980 \\
\hline Italia & Diploma di specialista in Ortognatodonzia & Università & 21. mai 2005 \\
\hline Kú $\pi \rho \circ$ & 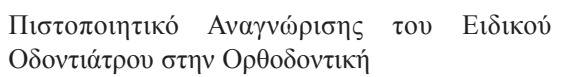 & 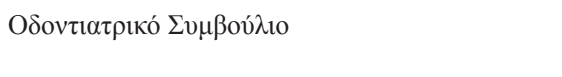 & 1. mai 2004 \\
\hline Latvija & $\begin{array}{l}\text { «Sertifikāts»_- kompetentas iestādes izsniegts } \\
\text { dokuments, kas apliecina, ka persona ir } \\
\text { nokārtojusi sertifikācijas eksāmenu ortodontijā }\end{array}$ & Latvijas Ārstu biedrība & 1. mai 2004 \\
\hline Lietuva & $\begin{array}{l}\text { Rezidentūros pažymėjimas, nurodantis suteiktą } \\
\text { gydytojo ortodonto profesinę kvalifikaciją }\end{array}$ & Universitetas & 1. mai 2004 \\
\hline Magyarország & Fogszabályozás szakorvosa bizonyítvány & $\begin{array}{l}\text { Az Egészségügyi, Szociális és Családügyi } \\
\text { Minisztérium illetékes testülete }\end{array}$ & 1. mai 2004 \\
\hline Malta & Ċertifikat ta' speċjalista dentali fl-Ortodonzja & Kumitat ta’ Approvazzjoni dwar Speċjalisti & 1. mai 2004 \\
\hline Nederland & $\begin{array}{l}\text { Bewijs van inschrijving als orthodontist in het } \\
\text { Specialistenregister }\end{array}$ & $\begin{array}{l}\text { Specialisten Registratie Commissie (SRC) van } \\
\text { de Nederlandse Maatschappij tot bevordering der } \\
\text { Tandheelkunde }\end{array}$ & 28. januar 1980 \\
\hline Polska & $\begin{array}{l}\text { Dyplom uzyskania tytułu specjalisty w dziedzinie } \\
\text { ortodoncji }\end{array}$ & Centrum Egzaminów Medycznych & 1. mai 2004 \\
\hline Slovenija & $\begin{array}{l}\text { Potrdilo o opravljenem specialističnem izpitu iz } \\
\text { čeljustne in zobne ortopedije }\end{array}$ & $\begin{array}{l}\text { 1. Ministrstvo za zdravje } \\
\text { 2. Zdravniška zbornica Slovenije }\end{array}$ & 1. mai 2004 \\
\hline Suomi/Finland & $\begin{array}{l}\text { Erikoishammaslääkärin tutkinto, hampaiston } \\
\text { oikomishoito/Specialtand-läkarexamen, } \\
\text { tandreglering }\end{array}$ & $\begin{array}{ll}- & \text { Helsingin yliopisto/Helsingfors universitet } \\
\text { - } & \text { Oulun yliopisto } \\
\text { - } & \text { Turun yliopisto }\end{array}$ & 1. januar 1994 \\
\hline Sverige & Bevis om specialistkompetens i tandreglering & Socialstyrelsen & 1. januar 1994 \\
\hline United Kingdom & $\begin{array}{l}\text { Certificate of Completion of specialist training } \\
\text { in orthodontics }\end{array}$ & Competent authority recognised for this purpose & 28. januar 1980 \\
\hline
\end{tabular}




\begin{tabular}{|c|c|c|c|}
\hline \multicolumn{4}{|c|}{ Oralkirurgi } \\
\hline Stat & Kvalifikasjonsbevis & Organ som utsteder kvalifikasjonsbevis & Referansedato \\
\hline Danmark & $\begin{array}{l}\text { Bevis for tilladelse til at betegne } \\
\text { sig som specialtandlæge i } \\
\text { hospitalsodontologi }\end{array}$ & Sundhedsstyrelsen & 28. januar 1980 \\
\hline Deutschland & $\begin{array}{l}\text { Fachzahnärztliche } \\
\text { Anerkennung für Oralchirurgie/ } \\
\text { Mundchirurgie }\end{array}$ & Landeszahnärztekammer & 28. januar 1980 \\
\hline 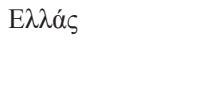 & 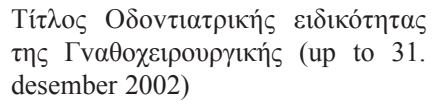 & 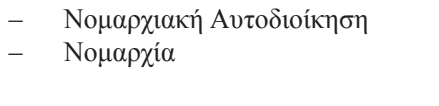 & 1. januar 2003 \\
\hline Ireland & $\begin{array}{l}\text { Certificate of specialist dentist in } \\
\text { oral surgery }\end{array}$ & $\begin{array}{l}\text { Competent authority recognised } \\
\text { for this purpose by the competent } \\
\text { minister }\end{array}$ & 28. januar 1980 \\
\hline Italia & $\begin{array}{l}\text { Diploma di specialista in Chirurgia } \\
\text { Orale }\end{array}$ & Università & 21. mai 2005 \\
\hline Kú $\pi \rho \circ \varsigma$ & 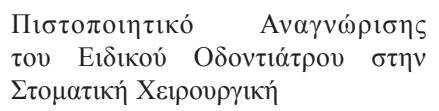 & 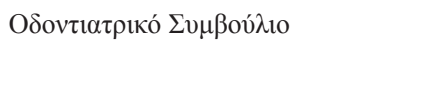 & 1. mai 2004 \\
\hline Lietuva & $\begin{array}{l}\text { Rezidentūros pažymėjimas, } \\
\text { nurodantis suteiktą burnos chirurgo } \\
\text { profesinę kvalifikaciją }\end{array}$ & Universitetas & 1. mai 2004 \\
\hline Magyarország & $\begin{array}{l}\text { Dento-alveoláris sebészet szakorvosa } \\
\text { bizonyítvány }\end{array}$ & $\begin{array}{l}\text { Az Egészségügyi, Szociális és } \\
\text { Családügyi Minisztérium illetékes } \\
\text { testülete }\end{array}$ & 1. mai 2004 \\
\hline Malta & $\begin{array}{l}\text { Certifikat ta’ speċjalista dentali fil- } \\
\text { Kirurgija tal-halq }\end{array}$ & $\begin{array}{l}\text { Kumitat ta' Approvazzjoni dwar } \\
\text { Specjalisti }\end{array}$ & 1. mai 2004 \\
\hline Nederland & $\begin{array}{l}\text { Bewijs van inschrijving als } \\
\text { kaakchirurg in het Specialistenregister }\end{array}$ & $\begin{array}{l}\text { Specialisten Registratie Commissie } \\
\text { (SRC) van de Nederlandse } \\
\text { Maatschappij tot bevordering der } \\
\text { Tandheelkunde }\end{array}$ & 28. januar 1980 \\
\hline Polska & 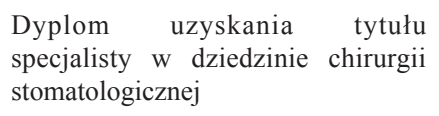 & Centrum Egzaminów Medycznych & 1. mai 2004 \\
\hline Slovenija & $\begin{array}{l}\text { Potrdilo o opravljenem } \\
\text { specialističnem izpitu iz oralne } \\
\text { kirurgije }\end{array}$ & $\begin{array}{l}\text { 1. Ministrstvo za zdravje } \\
\text { 2. Zdravniška zbornica Slovenije }\end{array}$ & 1. mai 2004 \\
\hline Suomi/ Finland & $\begin{array}{l}\text { Erikoishammaslääkärin tutkinto, suu- } \\
\text { ja leuka-kirurgia/Specialtandläkar- } \\
\text { examen, oral och maxillofacial } \\
\text { kirurgi }\end{array}$ & $\begin{array}{l}\text { - Helsingin yliopisto/Helsingfors } \\
\text { universitet } \\
\text { - } \quad \text { Oulun yliopisto } \\
-\quad \text { Turun yliopisto }\end{array}$ & 1. januar 1994 \\
\hline Sverige & $\begin{array}{l}\text { Bevis om specialist-kompetens i } \\
\text { tandsystemets kirurgiska sjukdomar }\end{array}$ & Socialstyrelsen & 1. januar 1994 \\
\hline United Kingdom & $\begin{array}{l}\text { Certificate of completion of specialist } \\
\text { training in oral surgery }\end{array}$ & $\begin{array}{l}\text { Competent authority recognised for } \\
\text { this purpose }\end{array}$ & 28. januar 1980 \\
\hline
\end{tabular}




\section{V.4. Veterinær}

\subsubsection{Studieprogram for veterincerer}

Studieprogrammet som skal føre kvalifikasjonsbevis som veterinær, skal minst omfatte følgende fag.

Undervisningen i ett eller flere av disse fagene kan skje innenfor eller i tilknytning til de øvrige fagene.

A. Grunnleggende fag

- Fysikk

- Kjemi

- Zoologi

- Plantebiologi

- Biomatematikk

B. Spesialfag

a. Grunnleggende fag

- Anatomi (herunder histologi og
embryologi)
- Fysiologi
- Biokjemi
- Genetikk
- Farmakologi
- Farmasi
$-\quad$ Toksikologi
- Mikrobiologi
- Immunologi
- Epidemiologi
- Yrkesetikk

b. Kliniske fag

$$
\begin{aligned}
& \text { - Obstetrikk } \\
& \text { - Patologi (herunder patologisk } \\
& \text { anatomi) } \\
& \text { - Parasittologi } \\
& \text { - Klinisk medisin og kirurgi } \\
& \text { (herunder anestesiologi) } \\
& \text { - Klinisk undervisning om ulike } \\
& \text { - Forebyggende medisin } \\
& \text { - Radiologi } \\
& \text { - Forplantning } \\
& \text { forplantningslidelser } \\
& \text { - Offentlig veterinærmedisin og }
\end{aligned}
$$

\begin{tabular}{|c|c|c|c|c|}
\hline Stat & Kvalifikasjonsbevis & $\begin{array}{l}\text { Organ som utsteder } \\
\text { kvalifikasjonsbeviset }\end{array}$ & $\begin{array}{l}\text { Attest som ledsager } \\
\text { kvalifikasjonsbeviset }\end{array}$ & Referansedato \\
\hline $\begin{array}{l}\text { België/Belgique/ } \\
\text { Belgien }\end{array}$ & $\begin{array}{l}\text { Diploma van dierenarts/Diplôme } \\
\text { de docteur en médecine vétérinaire }\end{array}$ & 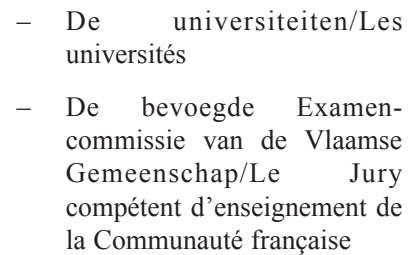 & & $\begin{array}{l}\text { 21. desember } \\
1980\end{array}$ \\
\hline
\end{tabular}

c. Animalsk produksjon

$$
\begin{aligned}
& \text { - Animalsk produksjon } \\
& \text { - } \text { Animalsk ernæring } \\
& \text { - } \text { Agronomi } \\
& \text { - Landbruksøkonomi } \\
& \text { - Dyrehold } \\
& \text { - } \text { Veterinærhygiene } \\
& \text { - Dyreetologi og dyrevern }
\end{aligned}
$$

d. Næringsmiddelhygiene

- Inspeksjon og kontroll av fôr eller næringsmidler av animalsk opprinnelse

- Næringsmiddelhygiene og -teknologi

- Praktisk arbeid (herunder praktisk arbeid på steder med slakting og behandling av næringsmidler)

Praktisk utdanning kan skje i form av en praksistid, forutsatt at dette foregår på heltid og under direkte tilsyn av vedkommende myndighet, og ikke overstiger seks måneder innenfor den samlede utdanningsperioden på fem år.

Fordelingen av teoretisk og praktisk utdanning i de ulike gruppene av emner skal være balansert og samordnet slik at kunnskap og erfaring kan tilegnes på en måte som vil gjøre det mulig for veterinæren å utføre alle sine oppgaver.

5.4.2. Kvalifikasjonsbevis - veterinar 


\begin{tabular}{|c|c|c|c|c|}
\hline Stat & Kvalifikasjonsbevis & $\begin{array}{l}\text { Organ som utsteder } \\
\text { kvalifikasjonsbeviset }\end{array}$ & $\begin{array}{l}\text { Attest som ledsager } \\
\text { kvalifikasjonsbeviset }\end{array}$ & Referansedato \\
\hline Česká republika & $\begin{array}{l}\text { - Diplom o ukončení studia } \\
\text { ve studijním programu } \\
\text { veterinární lékařství (doktor } \\
\text { veterinární medicíny, MVDr.) } \\
\text { - Diplom o ukončení studia } \\
\text { ve studijním programu } \\
\text { veterinární hygiena a ekologie } \\
\text { (doktor veterinární medicíny, } \\
\text { MVDr.) }\end{array}$ & $\begin{array}{l}\text { Veterinární fakulta univerzity v } \\
\text { České republice }\end{array}$ & & 1. mai 2004 \\
\hline Danmark & $\begin{array}{l}\text { Bevis for bestået kandidateksamen } \\
\text { i veterinærvidenskab }\end{array}$ & $\begin{array}{l}\text { Kongelige Veterinær- og } \\
\text { Landbohøjskole }\end{array}$ & & $\begin{array}{l}\text { 21. desember } \\
1980\end{array}$ \\
\hline Deutschland & $\begin{array}{l}\text { Zeugnis über das Ergebnis } \\
\text { des Dritten Abschnitts der } \\
\text { Tierärztlichen Prüfung und das } \\
\text { Gesamtergebnis der Tierärztlichen } \\
\text { Prüfung }\end{array}$ & $\begin{array}{l}\text { Der Vorsitzende des } \\
\text { Prüfungsausschusses für die } \\
\text { Tierärztliche Prüfung einer } \\
\text { Universität oder Hochschule }\end{array}$ & & $\begin{array}{l}\text { 21. desember } \\
1980\end{array}$ \\
\hline Eesti & $\begin{array}{ll}\text { Diplom: } & \text { täitnud } \\
\text { veterinaarmeditsiini õppekava }\end{array}$ & Eesti Põllumajandusülikool & & 1. mai 2004 \\
\hline$E \lambda \lambda \dot{\alpha} \varsigma$ & 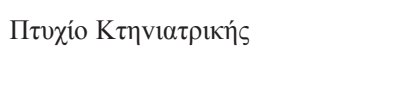 & 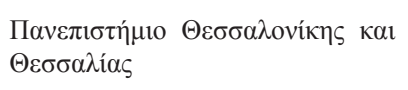 & & 1. januar 1981 \\
\hline España & Título de Licenciado en Veterinaria & $\begin{array}{l}\text { Ministerio de Educación y } \\
\text { Cultura } \\
\text { - } \quad \text { El rector de una universidad }\end{array}$ & & 1. januar 1986 \\
\hline France & $\begin{array}{l}\text { Diplôme d'Etat de docteur } \\
\text { vétérinaire }\end{array}$ & & & $\begin{array}{l}\text { 21. desember } \\
1980\end{array}$ \\
\hline Ireland & 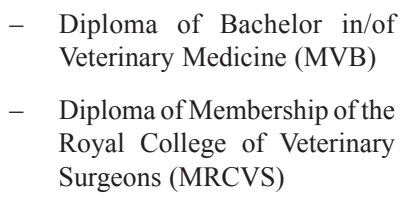 & & & $\begin{array}{l}\text { 21. desember } \\
1980\end{array}$ \\
\hline Italia & $\begin{array}{l}\text { Diploma di laurea in medicina } \\
\text { veterinaria }\end{array}$ & Università & $\begin{array}{l}\text { Diploma di } \begin{array}{l}\text { abilitazione } \\
\text { all'esercizio della medicina } \\
\text { veterinaria }\end{array} \\
\end{array}$ & 1. januar 1985 \\
\hline 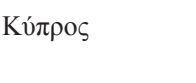 & 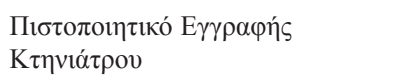 & 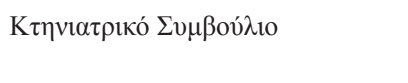 & & 1. mai 2004 \\
\hline Latvija & Veterinārārsta diploms & $\begin{array}{l}\text { Latvijas Lauksaimniecības } \\
\text { Universitāte }\end{array}$ & & 1. mai 2004 \\
\hline Lietuva & $\begin{array}{l}\text { Aukštojo mokslo diplomas } \\
\text { (veterinarijos gydytojo (DVM)) }\end{array}$ & Lietuvos Veterinarijos Akademija & & 1. mai 2004 \\
\hline
\end{tabular}




\begin{tabular}{|c|c|c|c|c|}
\hline Stat & Kvalifikasjonsbevis & $\begin{array}{l}\text { Organ som utsteder } \\
\text { kvalifikasjonsbeviset }\end{array}$ & $\begin{array}{l}\text { Attest som ledsager } \\
\text { kvalifikasjonsbeviset }\end{array}$ & Referansedato \\
\hline Luxembourg & $\begin{array}{l}\text { Diplôme d'Etat de docteur en } \\
\text { médecine vétérinaire }\end{array}$ & Jury d'examen d'Etat & & $\begin{array}{l}\text { 21. desember } \\
1980\end{array}$ \\
\hline Magyarország & $\begin{array}{l}\text { Állatorvos doktor oklevél - } \\
\text { dr. med. vet. }\end{array}$ & $\begin{array}{l}\text { Szent István Egyetem Állatorvos- } \\
\text { tudományi Kar }\end{array}$ & & 1. mai 2004 \\
\hline Malta & Liċenzja ta' Kirurgu Veterinarju & Kunsill tal-Kirurgi Veterinarji & & 1. mai 2004 \\
\hline Nederland & $\begin{array}{l}\text { Getuigschrift van met goed gevolg } \\
\text { afgelegd diergeneeskundig/ } \\
\text { veeartse-nijkundig examen }\end{array}$ & & & $\begin{array}{l}\text { 21. desember } \\
1980\end{array}$ \\
\hline Österreich & $\begin{array}{ll}- & \text { Diplom-Tierarzt } \\
\text { - } & \text { Magister } \\
\text { veterinariae }\end{array}$ & Universität & $\begin{array}{l}\text { - Doktor der Veterinärmedizin } \\
\text { - Doctor medicinae veterinariae } \\
\text { - Fachtierarzt }\end{array}$ & 1. januar 1994 \\
\hline Polska & Dyplom lekarza weterynarii & $\begin{array}{l}\text { 1. Szkoła Główna Gospodarstwa } \\
\text { Wiejskiego w Warszawie } \\
\text { 2. Akademia Rolnicza we } \\
\text { Wrocławiu } \\
\text { 3. Akademia Rolnicza w Lublinie } \\
\text { 4. Uniwersytet Warmińsko- } \\
\text { Mazurski w Olsztynie }\end{array}$ & & 1. mai 2004 \\
\hline Portugal & $\begin{array}{l}\text { Carta de curso de licenciatura em } \\
\text { medicina veterinária }\end{array}$ & Universidade & & 1. januar 1986 \\
\hline Slovenija & $\begin{array}{l}\text { Diploma, s katero se podeljuje } \\
\text { strokovni naslov «doktor } \\
\text { veterinarske medicine/doktorica } \\
\text { veterinarske medicine» }\end{array}$ & Univerza & $\begin{array}{lcc}\text { Spričevalo o } & \text { opravljenem } \\
\text { državnem izpitu } & \text { s področja } \\
\text { veterinarstva } & & \end{array}$ & 1. mai 2004 \\
\hline Slovensko & $\begin{array}{l}\text { Vysokoškolský diplom o } \\
\text { udelení akademického titulu } \\
\text { «doktor veterinárskej medicíny» } \\
\text { («MVDr.») }\end{array}$ & $\begin{array}{l}\text { Univerzita veterinárskeho } \\
\text { lekárstva }\end{array}$ & & 1. mai 2004 \\
\hline Suomi/ Finland & $\begin{array}{l}\text { Eläinlääketieteen lisensiaatin } \\
\text { tutkinto/Veterinärmedicine } \\
\text { licentiatexamen }\end{array}$ & $\begin{array}{l}\text { Helsingin yliopisto/Helsingfors } \\
\text { universitet }\end{array}$ & & 1. januar 1994 \\
\hline Sverige & Veterinärexamen & Sveriges Lantbruksuniversitet & & 1. januar 1994 \\
\hline \multirow[t]{6}{*}{ United Kingdom } & $\begin{array}{l}\text { 1. Bachelor of Veterinary Science } \\
\text { (BVSc) }\end{array}$ & 1. University of Bristol & & \multirow[t]{6}{*}{$\begin{array}{l}\text { 21. desember } \\
1980\end{array}$} \\
\hline & $\begin{array}{l}\text { 2. Bachelor of Veterinary Science } \\
\text { (BVSc) }\end{array}$ & 2. University of Liverpool & & \\
\hline & $\begin{array}{l}\text { 3. Bachelor of Veterinary Medicine } \\
\text { (BvetMB) }\end{array}$ & 3. University of Cambridge & & \\
\hline & $\begin{array}{l}\text { 4. Bachelor of Veterinary Medicine } \\
\text { and Surgery (BVM\&S) }\end{array}$ & 4. University of Edinburgh & & \\
\hline & $\begin{array}{l}\text { 5. Bachelor of Veterinary Medicine } \\
\text { and Surgery (BVM\&S) }\end{array}$ & 5. University of Glasgow & & \\
\hline & $\begin{array}{l}\text { 6. Bachelor of Veterinary Medicine } \\
\text { (BvetMed) }\end{array}$ & 6. University of London & & \\
\hline
\end{tabular}




\section{V.5. JORDMOR}

\subsubsection{Studieprogram for jordmødre (utdanning av type I og II)}

Studieprogrammet for å oppnå kvalifikasjonsbevis som jordmor omfatter følgende to deler:

A. Teoretisk og teknisk undervisning

a. Grunnleggende fag

$$
\begin{aligned}
& \text { - } \text { Grunnleggende anatomi og fysiologi } \\
& \text { - } \text { Grunnleggende patologi } \\
& \text { - } \quad \text { Grunnleggende bakteriologi, virologi og parasittologi } \\
& \text { - } \quad \text { Grunnleggende biofysikk, biokjemi og radiologi } \\
& \text { - } \quad \text { Pediatri, særlig med hensyn til nyfødte } \\
& \text { - } \quad \text { Hygiene, helselære, forebyggende medisin, } \\
& \quad \text { tidlig diagnostisering av sykdommer } \\
& \text { - } \quad \text { Ernæring og dietetikk, særlig med hensyn } \\
& \quad \text { til kvinner, nyfødte og spedbarn } \\
& \text { - } \quad \text { Grunnleggende sosiologi og sosialmedisinske spørsmål } \\
& \text { - } \quad \text { Grunnleggende farmakologi } \\
& \text { - } \quad \text { Psykologi } \\
& \text { - } \quad \text { Undervisningsprinsipper og -metoder } \\
& \text { - } \quad \text { Helse- og sosiallovgivning og helsevesenets organisering } \\
& \text { - } \quad \text { Yrkesetikk og -lovgivning } \\
& \text { - } \quad \text { Seksualundervisning og familieplanlegging } \\
& \text { - } \quad \text { Rettssikkerhet for mor og barn }
\end{aligned}
$$

\section{B. Praktisk og klinisk utdanning}

Denne utdanningen skal foregå under egnet tilsyn og omfatte:

- Rådgivning for gravide kvinner, herunder minst 100 prenatale undersøkelser.

- Tilsyn med og pleie av minst 40 fødende kvinner.

- Eleven skal ha forestått minst 40 fødsler, men der dette antallet ikke kan nås på grunn av mangel på fødende, kan antallet reduseres til minst 30, forutsatt at eleven deltar aktivt i arbeidet ved ytterligere 20 fødsler.

- Aktive deltaking ved setefødsler. Der dette ikke er mulig på grunn av mangel på setefødsler, kan praksis foregå i en simulert situasjon.

- Praktisk gjennomføring av episiotomi og innføring i sutur. Innføringen skal omfatte teoretisk undervisning og klinisk praksis. Suturpraksis omfatter sutur av livmoren etter en episiotomi og en enkel perineal rift. Dette kan, dersom det er absolutt nødvendig, skje i en simulert situasjon.

- Tilsyn med og pleie av 40 kvinner med komplikasjoner før, under eller etter fødsel.

- Tilsyn med og pleie av (herunder undersøkelse av) minst 100 kvinner som nettopp har født samt friske nyfødte barn.

- Tilsyn med og pleie av nyfødte som krever særlig pleie, herunder for tidlig og for sent fødte barn samt undervektige og syke nyfødte.

- Pleie av kvinner med patologiske tilstander innenfor gynekologi og obstetrikk.

- Innføring i pleie innenfor medisin og kirurgi. Innføringen skal omfatte teoretisk undervisning og klinisk praksis.

Den teoretiske og tekniske utdanningen (del A i studieprogrammet) skal være avpasset etter og samordnet med den kliniske utdanningen (del B i det samme programmet), slik at de kunnskapene og den erfaringen som omfattes av dette vedlegg, kan tilegnes på en tilfredsstillende måte.

Den kliniske undervisningen skal foregå i form av veiledet praktisk undervisning på sykehusavdelinger eller i annen helsetjeneste godkjent av vedkommende myndigheter eller organer. Her skal jordmorelevene delta i de berørte avdelingenes virksomhet i den grad denne har utdanningsmessig verdi. De skal få opplæring i det ansvar som er knyttet til jordmorvirksomhet. 
5.5.2. Kvalifikasjonsbevis - jordmor

\begin{tabular}{|c|c|c|c|c|}
\hline Stat & Kvalifikasjonsbevis & $\begin{array}{l}\text { Organ som utsteder } \\
\text { kvalifikasjonsbeviset }\end{array}$ & Yrkestittel & Referansedato \\
\hline $\begin{array}{l}\text { België/Belgique/ } \\
\text { Belgien }\end{array}$ & $\begin{array}{l}\text { Diploma van vroedvrouw/ } \\
\text { Diplôme d'accoucheuse }\end{array}$ & 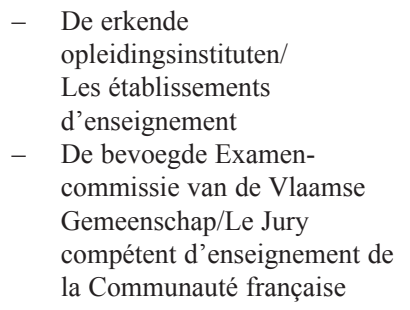 & Vroedvrouw/Accoucheuse & $\begin{array}{l}\text { 23. januar } \\
1983\end{array}$ \\
\hline \multirow[t]{2}{*}{ Česká republika } & $\begin{array}{l}\text { 1. Diplom o ukončení studia } \\
\text { ve studijním programu } \\
\text { ošetřovatelství ve studijním } \\
\text { oboru porodní asistentka } \\
\text { (bakalář, Bc.) } \\
\text { - Vysvědčení o státní závěrečné } \\
\text { zkoušce }\end{array}$ & $\begin{array}{l}\text { 1. Vysoká škola zř́zená nebo } \\
\text { uznaná státem }\end{array}$ & Porodní asistentka/porodní asistent & 1. mai 2004 \\
\hline & $\begin{array}{l}\text { 2. Diplom o ukončení studia ve } \\
\text { studijním oboru diplomovaná } \\
\text { porodní } \\
\text { (diplomovaný asistentka } \\
\text { DiS.) } \\
\text { - } \\
\text { Vysvecialista, } \\
\end{array}$ & $\begin{array}{l}\text { 2. Vyšší odborná škola zř́izená } \\
\text { nebo uznaná státem }\end{array}$ & & \\
\hline Danmark & $\begin{array}{l}\text { Bevis for bestået } \\
\text { jordemodereksamen }\end{array}$ & Danmarks jordemoderskole & Jordemoder & $\begin{array}{l}23 . \quad \text { januar } \\
1983\end{array}$ \\
\hline Deutschland & $\begin{array}{l}\text { Zeugnis über die staatliche } \\
\text { Prüfung für Hebammen und } \\
\text { Entbindungspfleger }\end{array}$ & Staatlicher Prüfungsausschuss & $\begin{array}{ll}- & \text { Hebamme } \\
- & \text { Entbindungspfleger }\end{array}$ & $\begin{array}{l}23 . \quad \text { januar } \\
1983\end{array}$ \\
\hline Eesti & Diplom ämmaemanda erialal & $\begin{array}{l}\text { 1. Tallinna Meditsiinikool } \\
\text { 2. Tartu Meditsiinikool }\end{array}$ & - $\quad$ Ämmaemand & 1. mai 2004 \\
\hline \multirow[t]{3}{*}{$\mathrm{E} \lambda \lambda \dot{\alpha} \varsigma$} & 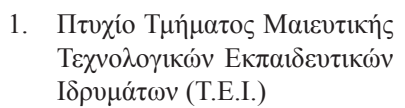 & 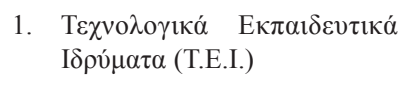 & 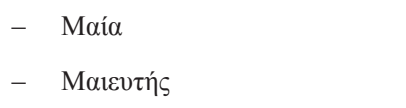 & $\begin{array}{l}23 . \quad \text { januar } \\
1983\end{array}$ \\
\hline & 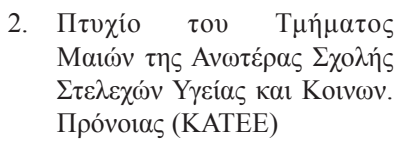 & 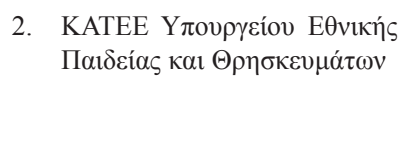 & & \\
\hline & 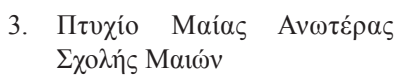 & 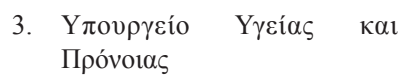 & & \\
\hline España & $\begin{array}{l}\text { - } \quad \text { Título de Matrona } \\
\text { - } \quad \text { Título de Asistente obstétrico } \\
\text { (matrona) } \\
\text { - Título de Enfermería } \\
\text { obstétrica-ginecológica }\end{array}$ & $\begin{array}{l}\text { Ministerio de Educación y } \\
\text { Cultura }\end{array}$ & $\begin{array}{ll}- & \text { Matrona } \\
- & \text { Asistente obstétrico }\end{array}$ & 1. januar 1986 \\
\hline France & Diplôme de sage-femme & L'Etat & Sage-femme & $\begin{array}{l}23 . \quad \text { januar } \\
1983 \text { r }\end{array}$ \\
\hline Ireland & Certificate in Midwifery & An Board Altranais & Midwife & $\begin{array}{ll}23 . & \text { januar } \\
1983 & \end{array}$ \\
\hline Italia & Diploma d'ostetrica & Scuole riconosciute dallo Stato & Ostetrica & $\begin{array}{l}\text { 23. januar } \\
1983 \text { r }\end{array}$ \\
\hline
\end{tabular}




\begin{tabular}{|c|c|c|c|c|}
\hline Stat & Kvalifikasjonsbevis & $\begin{array}{l}\text { Organ som utsteder } \\
\text { kvalifikasjonsbeviset }\end{array}$ & Yrkestittel & Referansedato \\
\hline 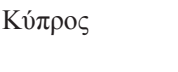 & 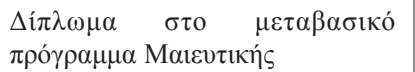 & 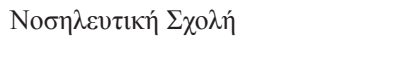 & 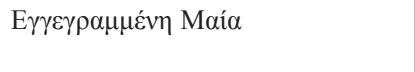 & 1. mai 2004 \\
\hline Latvija & $\begin{array}{l}\text { Diploms par vecmātes } \\
\text { kvalifikācijas iegūšanu }\end{array}$ & Māsu skolas & Vecmāte & 1. mai 2004 \\
\hline Lietuva & $\begin{array}{l}\text { 1. Aukštojo mokslo diplomas, } \\
\text { nurodantis suteiktą bendrosios } \\
\text { praktikos slaugytojo profesinę } \\
\text { kvalifikaciją, ir profesinès } \\
\text { kvalifikacijos pažymèjimas, } \\
\text { nurodantis suteiktą akušerio } \\
\text { profesinę kvalifikaciją } \\
\text { - } \begin{array}{l}\text { Pažymèjimas, liudijantis } \\
\text { profesinę praktiką akušerijoje }\end{array} \\
\text { 2. Aukštojo mokslo diplomas } \\
\text { (neuniversitetinès studijos), } \\
\text { nurodantis suteiktą bendrosios } \\
\text { praktikos slaugytojo profesinę } \\
\text { kvalifikacija, ir profesinęs } \\
\text { kvalifikacijos pažyméjimas, } \\
\text { nurodantis suteiktą akušerio } \\
\text { profesinę kvalifikaciją } \\
\text { - Pažymėjimas, liudijantis } \\
\text { profesinę praktiką } \\
\text { akušerijoje } \\
\text { Aukštojo mokslo diplomas } \\
\text { (neuniversitetinès studijos), } \\
\text { nurodantis suteiktą akušerio } \\
\text { profesinę kvalifikaciją }\end{array}$ & $\begin{array}{l}\text { 1. Universitetas } \\
\text { 2. Kolegija }\end{array}$ & Akušeris & 1. mai 2004 \\
\hline Luxembourg & Diplôme de sage-femme & $\begin{array}{l}\text { Ministère de l'éducation nationale, } \\
\text { de la formation professionnelle et } \\
\text { des sports }\end{array}$ & Sage-femme & $\begin{array}{l}23 . \quad \text { januar } \\
1983\end{array}$ \\
\hline Magyarország & Szülésznő bizonyítvány & Iskola/föiskola & Szülésznő & 1. mai 2004 \\
\hline Malta & $\begin{array}{l}\text { Lawrja jew diploma fl- Istudji tal- } \\
\text { Qwiebel }\end{array}$ & Universita' ta' Malta & Qabla & 1. mai 2004 \\
\hline Nederland & Diploma van verloskundige & $\begin{array}{l}\text { Door het Ministerie van } \\
\text { Volksgezondheid, Welzijn en Sport } \\
\text { erkende opleidings-instellingen }\end{array}$ & Verloskundige & $\begin{array}{l}23 . \quad \text { januar } \\
1983\end{array}$ \\
\hline Österreich & Hebammen-Diplom & $\begin{array}{l}\text { - Hebammenakademie } \\
\text { - Bundeshebammenlehranstalt }\end{array}$ & Hebamme & 1. januar 1994 \\
\hline Polska & $\begin{array}{l}\text { Dyplom ukończenia studiów } \\
\text { wyższych na kierunku położnictwo } \\
\text { z tytułem «magister położnictwa» }\end{array}$ & $\begin{array}{l}\text { Instytucja prowadząca kształcenie } \\
\text { na poziomie wyższym uznana } \\
\text { przez właściwe władze } \\
\text { (Høyere utdanningsinstitusjon } \\
\text { godkjent av vedkommende } \\
\text { myndigheter) }\end{array}$ & Położna & 1. mai 2004 \\
\hline Portugal & 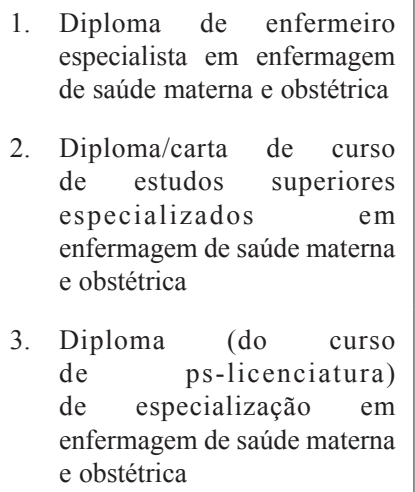 & $\begin{array}{l}\text { 1. Ecolas de Enfermagem } \\
\text { 2. Escolas Superiores de } \\
\text { Enfermagem }\end{array}$ & $\begin{array}{l}\text { Enfermeiro especialista em } \\
\text { enfermagem de saúde materna e } \\
\text { obstétrica }\end{array}$ & 1. januar 1986 \\
\hline
\end{tabular}




\begin{tabular}{|c|c|c|c|c|}
\hline Stat & Kvalifikasjonsbevis & $\begin{array}{l}\text { Organ som utsteder } \\
\text { kvalifikasjonsbeviset }\end{array}$ & Yrkestittel & Referansedato \\
\hline Slovenija & $\begin{array}{l}\text { Diploma, s katero se podeljuje } \\
\text { strokovni naslov «diplomirana } \\
\text { babica/diplomirani babičar» }\end{array}$ & $\begin{array}{l}\text { 1. Univerza } \\
\text { 2. Visoka strokovna šola }\end{array}$ & $\begin{array}{l}\text { diplomirana babica/diplomirani } \\
\text { babičar }\end{array}$ & 1. mai 2004 \\
\hline Slovensko & $\begin{array}{llr}\text { 1. Vysokoškolský } & \text { diplom } \\
\text { o udelení akademického } \\
\text { titulu «bakalár z } & \text { pôrodnej } \\
\text { asistencie» }(« B c . ») & \\
\text { 2. Absolventský } & \text { diplom } \\
\text { v študijnom } & \text { odbore } \\
\text { diplomovaná } & \text { pôrodná } \\
\text { asistentka } & \end{array}$ & $\begin{array}{l}\text { 1. Vysoká škola } \\
\text { 2. Stredná zdravotnícka škola }\end{array}$ & Pôrodná asistentka & 1. mai 2004 \\
\hline Suomi/ Finland & $\begin{array}{l}\text { 1. Kätilön tutkinto/ } \\
\text { barnmorskeexamen } \\
\text { 2. Sosiaali- ja terveysalan } \\
\text { ammattikorkeakoulututkinto, } \\
\text { kätilö (AMK)/ } \\
\text { yrkeshögskoleexamen inom } \\
\text { hälsovård och det sociala } \\
\text { området, barnmorska (YH) }\end{array}$ & $\begin{array}{l}\text { 1. Terveydenhuoltooppi- } \\
\text { laitokset/ } \\
\text { hälsovårdsläroanstalter } \\
\text { 2. Ammattikorkeakoulut/ } \\
\text { Yrkeshögskolor }\end{array}$ & Kätilö/Barnmorska & 1. januar 1994 \\
\hline Sverige & Barnmorskeexamen & Universitet eller högskola & Barnmorska & 1. januar 1994 \\
\hline United Kingdom & $\begin{array}{l}\text { Registreringserklæring som } \\
\text { jordmor i del } 10 \text { i registeret til } \\
\text { United Kingdom Central Council } \\
\text { for Nursing, Midwifery and Health } \\
\text { visiting }\end{array}$ & Flere & Midwife & $\begin{array}{l}23 . \quad \text { januar } \\
1983\end{array}$ \\
\hline
\end{tabular}

\section{V.6. FARMASØYT}

\subsubsection{Studieprogram for farmasøyter}

- Plantebiologi og zoologi

- Fysikk

- Generell og uorganisk kjemi

- Organisk kjemi

- Analytisk kjemi

- Farmasøytisk kjemi, herunder analyse av legemidler

- Generell og anvendt biokjemi (medisinsk)

- Anatomi og fysiologi samt medisinsk terminologi

- Mikrobiologi

- Farmakologi og farmakoterapi

- Farmasøytisk teknologi

- Toksikologi

- Farmakognosi

- Lovgivning og, der dette er hensiktsmessig, yrkesetikk

I balanseringen av teoretisk og praktisk utdanning skal det for hvert enkelt emne legges tilstrekkelig vekt på teori for å opprettholde utdanningens akademiske karakter. 
5.6.2. Kvalifikasjonsbevis - farmasøyt

\begin{tabular}{|c|c|c|c|c|}
\hline Stat & Kvalifikasjonsbevis & $\begin{array}{l}\text { Organ som utsteder } \\
\text { kvalifikasjonsbeviset }\end{array}$ & $\begin{array}{l}\text { Attest som ledsager } \\
\text { kvalifikasjonsbeviset }\end{array}$ & Referansedato \\
\hline $\begin{array}{l}\text { België/Belgique/ } \\
\text { Belgien }\end{array}$ & $\begin{array}{l}\text { Diploma van apotheker/Diplôme } \\
\text { de pharmacien }\end{array}$ & $\begin{array}{l}\text { - } \begin{array}{l}\text { De universiteiten/Les } \\
\text { universités }\end{array} \\
\text { - } \text { De bevoegde } \\
\text { Examencommissie van de } \\
\text { Vlaamse Gemeenschap/ } \\
\text { Le Jury compétent } \\
\text { d'enseignement de la } \\
\text { Communauté française }\end{array}$ & & 1. oktober 1987 \\
\hline Česká republika & $\begin{array}{l}\text { Diplom o ukončení studia ve } \\
\text { studijním programu farmacie } \\
\text { (magistr, Mgr.) }\end{array}$ & $\begin{array}{l}\text { Farmaceutická fakulta univerzity } \\
\text { v České republice }\end{array}$ & $\begin{array}{l}\text { Vysvědčení o státní závěrečné } \\
\text { zkoušce }\end{array}$ & 1. mai 2004 \\
\hline Danmark & $\begin{array}{l}\text { Bevis for bestået farmaceutisk } \\
\text { kandidateksamen }\end{array}$ & $\begin{array}{l}\text { Danmarks } \quad \text { Farmaceutiske } \\
\text { Højskole }\end{array}$ & & 1. oktober 1987 \\
\hline Deutschland & $\begin{array}{l}\text { Zeugnis über die Staatliche } \\
\text { Pharmazeutische Prüfung }\end{array}$ & Zuständige Behörden & & 1. oktober 1987 \\
\hline Eesti & $\begin{array}{l}\text { Diplom proviisori õppekava } \\
\text { läbimisest }\end{array}$ & Tartu Ülikool & & 1. mai 2004 \\
\hline 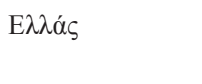 & 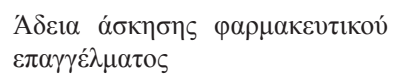 & 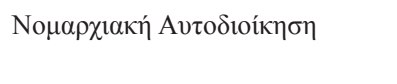 & & 1. oktober 1987 \\
\hline España & Título de Licenciado en Farmacia & $\begin{array}{l}\text { - Ministerio de Educación y } \\
\text { Cultura } \\
\text { - } \quad \text { El rector de una universidad }\end{array}$ & & 1. oktober 1987 \\
\hline France & $\begin{array}{l}\text { - } \begin{array}{l}\text { Diplôme d'Etat de } \\
\text { pharmacien }\end{array} \\
\text { - } \begin{array}{l}\text { Diplôme d'Etat de docteur en } \\
\text { pharmacie }\end{array}\end{array}$ & Universités & & 1. oktober 1987 \\
\hline Ireland & $\begin{array}{l}\text { Certificate of Registered } \\
\text { Pharmaceutical Chemist }\end{array}$ & & & 1. oktober 1987 \\
\hline Italia & $\begin{array}{l}\text { Diploma o certificato di } \\
\text { abilitazione all'esercizio della } \\
\text { professione di farmacista ottenuto } \\
\text { in seguito ad un esame di Stato }\end{array}$ & Università & & $\begin{array}{l}1 \text { November } \\
1993\end{array}$ \\
\hline Ки́ & 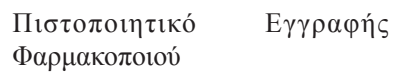 & 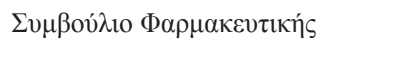 & & 1. mai 2004 \\
\hline Latvija & Farmaceita diploms & Universitātes tipa augstskola & & 1. mai 2004 \\
\hline Lietuva & $\begin{array}{l}\text { Aukštojo mokslo diplomas, } \\
\text { nurodantis suteiktą vaistininko } \\
\text { profesinę kvalifikaciją }\end{array}$ & Universitetas & & 1. mai 2004 \\
\hline
\end{tabular}




\begin{tabular}{|c|c|c|c|c|}
\hline Stat & Kvalifikasjonsbevis & $\begin{array}{l}\text { Organ som utsteder } \\
\text { kvalifikasjonsbeviset }\end{array}$ & $\begin{array}{l}\text { Attest som ledsager } \\
\text { kvalifikasjonsbeviset }\end{array}$ & Referansedato \\
\hline Luxembourg & Diplôme d'Etat de pharmacien & $\begin{array}{l}\text { Jury d'examen d'Etat }+ \text { visa du } \\
\text { ministre de l'éducation nationale }\end{array}$ & & 1. oktober 1987 \\
\hline Magyarország & $\begin{array}{l}\text { Okleveles gyógyszerész oklevél } \\
\text { (magister pharmaciae, röv: mag. } \\
\text { Pharm) }\end{array}$ & Egyetem & & 1. mai 2004 \\
\hline Malta & Lawrja fil-farmacija & Universita' ta' Malta & & 1. mai 2004 \\
\hline Nederland & $\begin{array}{l}\text { Getuigschrift van met goed gevolg } \\
\text { afgelegd apothekersexamen }\end{array}$ & Faculteit Farmacie & & 1. oktober 1987 \\
\hline Österreich & Staatliches Apothekerdiplom & $\begin{array}{l}\text { Bundesministerium für Arbeit, } \\
\text { Gesundheit und Soziales }\end{array}$ & & 1. oktober 1994 \\
\hline Polska & $\begin{array}{l}\text { Dyplom ukończenia studiów } \\
\text { wyższych na kierunku farmacja z } \\
\text { tytułem magistra }\end{array}$ & $\begin{array}{l}\text { 1. Akademia Medyczna } \\
\text { 2. Uniwersytet Medyczny } \\
\text { 3. Collegium Medicum } \\
\text { Uniwersytetu Jagiellońskiego }\end{array}$ & & 1. mai 2004 \\
\hline Portugal & $\begin{array}{l}\text { Carta de curso de licenciatura em } \\
\text { Ciências Farmacêuticas }\end{array}$ & Universidades & & 1. oktober 1987 \\
\hline Slovenija & $\begin{array}{l}\text { Diploma, s katero se podeljuje } \\
\text { strokovni naziv «magister } \\
\text { farmacije/magistra farmacije» }\end{array}$ & Univerza & $\begin{array}{l}\text { Potrdilo o opravljenem } \\
\text { strokovnem izpitu za poklic } \\
\text { magister farmacije/magistra } \\
\text { farmacije }\end{array}$ & 1. mai 2004 \\
\hline Slovensko & $\begin{array}{l}\text { Vysokoškolský diplom o udelení } \\
\text { akademického titulu «magister } \\
\text { farmácie» («Mgr.») }\end{array}$ & Vysoká škola & & 1. mai 2004 \\
\hline Suomi/ Finland & $\begin{array}{l}\text { Proviisorin } \\
\text { Provisorexamen }\end{array}$ & $\begin{array}{l}\text { - Helsingin yliopisto/ } \\
\text { Helsingfors universitet } \\
-\quad \text { Kuopion yliopisto }\end{array}$ & & 1. oktober 1994 \\
\hline Sverige & Apotekarexamen & Uppsala universitet & & 1. oktober 1994 \\
\hline United Kingdom & $\begin{array}{l}\text { Certificate of Registered } \\
\text { Pharmaceutical Chemist }\end{array}$ & & & 1. oktober 1987 \\
\hline
\end{tabular}




\section{7. ARKITEKT}

5.7.1. Kvalifikasjonsbevis - arkitekt godkjent $i$ henhold til artikkel 46

\begin{tabular}{|c|c|c|c|c|}
\hline Stat & Kvalifikasjonsbevis & $\begin{array}{l}\text { Organ som utsteder } \\
\text { kvalifikasjonsbeviset }\end{array}$ & $\begin{array}{l}\text { Attest som ledsager } \\
\text { kvalifikasjonsbeviset }\end{array}$ & $\begin{array}{l}\text { Akademisk } \\
\text { referanseår }\end{array}$ \\
\hline \multirow[t]{2}{*}{$\begin{array}{l}\text { België/ Belgique/ } \\
\text { Belgien }\end{array}$} & $\begin{array}{l}\text { 1. Architect/Architecte } \\
\text { 2. Architect/Architecte } \\
\text { 3. Architect } \\
\text { 4. Architect/Architecte } \\
\text { 5. Architect/Architecte } \\
\text { 6. Burgelijke ingenieur- } \\
\text { architect }\end{array}$ & $\begin{array}{l}\text { 1. Nationale hogescholen voor } \\
\text { architectuur } \\
\text { 2. Hogere-architectuur- } \\
\text { instituten } \\
\text { 3. Provinciaal Hoger Instituut } \\
\text { voor Architectuur te Hasselt } \\
\text { 4. Koninklijke Academies voor } \\
\text { Schone Kunsten } \\
\text { 5. Sint-Lucasscholen } \\
\text { 6. Faculteiten Toegepaste } \\
\text { Wetenschappen van de } \\
\text { Universiteiten } \\
\text { 6. «Faculté Polytechnique» van } \\
\text { Mons }\end{array}$ & & \multirow[t]{2}{*}{$1988 / 1989$} \\
\hline & $\begin{array}{l}\text { 1. Architecte/Architect } \\
\text { 2. Architecte/Architect } \\
\text { 3. Architect } \\
\text { 4. Architecte/Architect } \\
\text { 5. Architecte/Architect } \\
\text { 6. Ingénieur-civil — architecte }\end{array}$ & $\begin{array}{l}\text { 1. Ecoles nationales supérieures } \\
\text { d'architecture } \\
\text { 2. Instituts supérieurs } \\
\text { d'architecture } \\
\text { 3. Ecole provinciale supérieure } \\
\text { d'architecture de Hasselt } \\
\text { 4. Académies royales des } \\
\text { Beaux-Arts } \\
\text { 5. Ecoles Saint-Luc } \\
\text { 6. Facultés des sciences } \\
\text { appliquées des universités } \\
\text { 6. Faculté polytechnique de } \\
\text { Mons }\end{array}$ & & \\
\hline Danmark & Arkitekt cand. arch. & $\begin{array}{ll}- & \text { Kunstakademiets } \\
& \text { Arkitektskole i København } \\
- & \text { Arkitektskolen i Århus }\end{array}$ & & $1988 / 1989$ \\
\hline \multirow[t]{2}{*}{ Deutschland } & $\begin{array}{l}\text { Diplom-Ingenieur, } \\
\text { Diplom-Ingenieur Univ. }\end{array}$ & $\begin{array}{ll}\text { - } & \text { Universitäten (Architektur/ } \\
\text { Hochbau) } \\
\text { - } \\
\text { Technische Hochschulen } \\
\text { (Architektur/Hochbau) } \\
\text { - Technische Universitäten } \\
\text { (Architektur/Hochbau) } \\
-\quad \text { Universitäten- } \\
\text { Gesamthochschulen } \\
\text { (Architektur/Hochbau) } \\
-\quad \text { Hochschulen für bildende } \\
\text { Künste } \\
- & \text { Hochschulen für Künste }\end{array}$ & & \multirow[t]{2}{*}{$1988 / 1989$} \\
\hline & $\begin{array}{l}\text { Diplom-Ingenieur, } \\
\text { Diplom-Ingenieur FH }\end{array}$ & $\begin{array}{l}\text { - Fachhochschulen (Architektur/ } \\
\text { Hochbau) }\left({ }^{1}\right) \\
\text { - Universitäten- } \\
\text { Gesamthochschulen } \\
\text { (Architektur/Hochbau) } \\
\text { bei entsprechenden } \\
\text { Fachhochschulstudiengängen } \\
\text { (1) Diese Diplome sind je } \\
\text { nach Dauer der durch sie } \\
\text { abgeschlossenen Ausbildung } \\
\text { gemäß Artikel 47 Absatz } 1 \\
\text { anzuerkennen. }\end{array}$ & & \\
\hline
\end{tabular}




\begin{tabular}{|c|c|c|c|c|}
\hline Stat & Kvalifikasjonsbevis & $\begin{array}{l}\text { Organ som utsteder } \\
\text { kvalifikasjonsbeviset }\end{array}$ & $\begin{array}{l}\text { Attest som ledsager } \\
\text { kvalifikasjonsbeviset }\end{array}$ & $\begin{array}{l}\text { Akademisk } \\
\text { referanseår }\end{array}$ \\
\hline 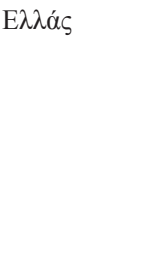 & $\begin{array}{l}\Delta i \pi \lambda \omega \mu \alpha \alpha \quad \alpha \rho \chi 1 \tau \varepsilon ́ \kappa \tau o v \alpha- \\
\mu \eta \chi \alpha v i \kappa o v ́\end{array}$ & 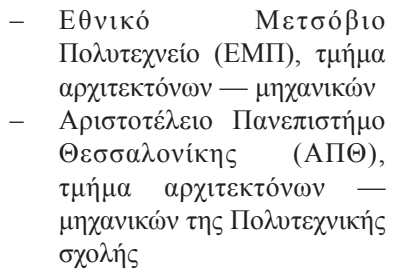 & 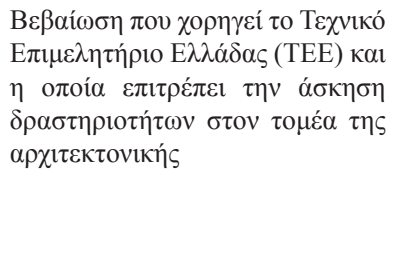 & 1988/1989 \\
\hline España & Título oficial de arquitecto & 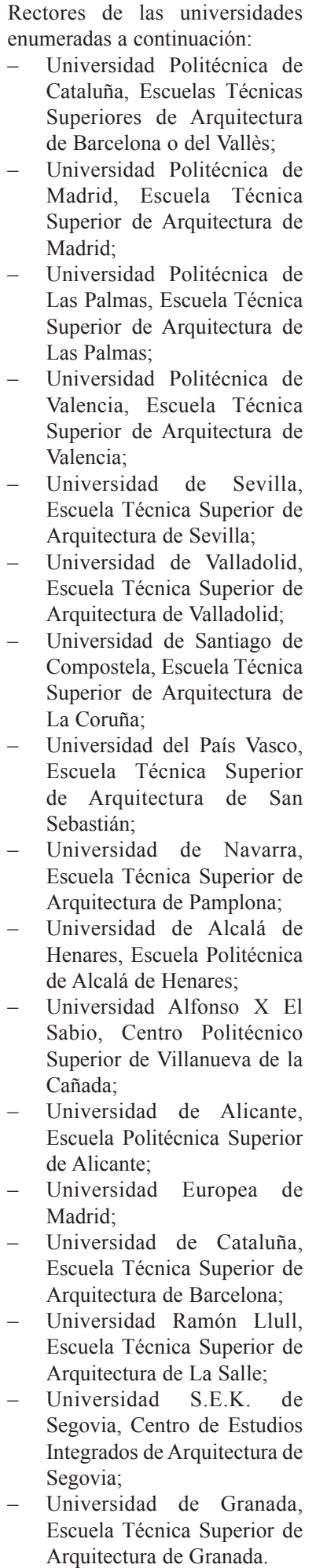 & & $\begin{array}{l}1988 / 1989 \\
1999 / 2000 \\
1999 / 2000 \\
1997 / 1998 \\
1998 / 1999 \\
1999 / 2000 \\
1998 / 1999 \\
1999 / 2000 \\
\end{array}$ \\
\hline
\end{tabular}




\begin{tabular}{|c|c|c|c|c|}
\hline Stat & Kvalifikasjonsbevis & $\begin{array}{l}\text { Organ som utsteder } \\
\text { kvalifikasjonsbeviset }\end{array}$ & $\begin{array}{l}\text { Attest som ledsager } \\
\text { kvalifikasjonsbeviset }\end{array}$ & $\begin{array}{l}\text { Akademisk } \\
\text { referanseår }\end{array}$ \\
\hline \multirow[t]{3}{*}{ France } & $\begin{array}{l}\text { Diplôme d'architecte DPLG, } \\
\text { y compris dans le cadre de } \\
\text { la formation professionnelle } \\
\text { continue et de la promotion } \\
\text { sociale. }\end{array}$ & $\begin{array}{l}\text { 1. Le ministre chargé de } \\
\text { l'architecture }\end{array}$ & & $1988 / 1989$ \\
\hline & 2. Diplôme d'architecte ESA & $\begin{array}{l}\text { 2. Ecole spéciale d'architecture } \\
\text { de Paris }\end{array}$ & & \\
\hline & $\begin{array}{l}\text { 3. Diplôme d'architecte } \\
\text { ENSAIS }\end{array}$ & $\begin{array}{l}\text { 3. Ecole nationale supérieure } \\
\text { des arts et industries } \\
\text { de Strasbourg, section } \\
\text { architecture }\end{array}$ & & \\
\hline \multirow[t]{4}{*}{ Ireland } & $\begin{array}{l}\text { 1. Degree of Bachelor of } \\
\text { Architecture (B.Arch. NUI) }\end{array}$ & $\begin{array}{l}\text { 1. National University of } \\
\text { Ireland to architecture } \\
\text { graduates of University } \\
\text { College Dublin }\end{array}$ & & $1988 / 1989$ \\
\hline & $\begin{array}{l}\text { 2. Degree of Bachelor of } \\
\text { Architecture (B.Arch.) } \\
\text { Previously, until 2002 - } \\
\text { Degree standard diploma in } \\
\text { architecture (Dip. Arch)) }\end{array}$ & $\begin{array}{l}\text { 2. Dublin Institute of } \\
\text { Technology, Bolton Street, } \\
\text { Dublin } \\
\text { College of Technology, } \\
\text { Bolton Street, Dublin) }\end{array}$ & & \\
\hline & $\begin{array}{l}\text { 3. Certificate of associateship } \\
\text { (ARIAI) }\end{array}$ & $\begin{array}{l}\text { 3. Royal Institute of Architects } \\
\text { of Ireland }\end{array}$ & & \\
\hline & $\begin{array}{l}\text { 4. Certificate of membership } \\
\text { (MRIAI) }\end{array}$ & $\begin{array}{l}\text { 4. Royal Institute of Architects } \\
\text { of Ireland }\end{array}$ & & \\
\hline \multirow[t]{2}{*}{ Italia } & 更 & $\begin{array}{ll}- & \text { Università di Camerino } \\
- & \text { Università di Catania } \\
& \text { Sede di Siracusa } \\
- & \text { Università di Chieti } \\
- & \text { Università di Ferrara } \\
- & \text { Università di Firenze } \\
- & \text { Università di Genova } \\
- & \text { Università di Napoli } \\
& \text { Federico II } \\
- & \text { Università di Napoli II } \\
- & \text { Università di Palermo } \\
- & \text { Università di Parma } \\
- & \text { Università di Reggio Calabria } \\
- & \text { Università di Roma «La } \\
& \text { Sapienza» } \\
- & \text { Universtià di Roma III } \\
- & \text { Università di Trieste } \\
- & \text { Politecnico di Bari } \\
- & \text { Politecnico di Milano } \\
- & \text { Politecnico di Torino } \\
- & \text { Istituto universitario di } \\
& \text { architettura di Venezia }\end{array}$ & $\begin{array}{l}\text { Diploma di abilitazione } \\
\text { all'esercizo indipendente della } \\
\text { professione che viene rilasciato } \\
\text { dal ministero della Pubblica } \\
\text { istruzione dopo che il candidato } \\
\text { ha sostenuto con esito positivo } \\
\text { l'esame di Stato davanti ad una } \\
\text { commissione competente }\end{array}$ & $1988 / 1989$ \\
\hline & $\begin{array}{l}\text { - Laurea in ingegneria edile - } \\
\text { architettura }\end{array}$ & $\begin{array}{ll}- & \text { Università dell’Aquilla } \\
- & \text { Università di Pavia } \\
- & \text { Università di Roma«La } \\
& \text { Sapienza» }\end{array}$ & $\begin{array}{l}\text { Diploma di abilitazione } \\
\text { all'esercizo indipendente della } \\
\text { professione che viene rilasciato } \\
\text { dal ministero della Pubblica } \\
\text { istruzione dopo che il candidato } \\
\text { ha sostenuto con esito positivo } \\
\text { l'esame di Stato davanti ad una } \\
\text { commissione competente }\end{array}$ & 1998/1999 \\
\hline
\end{tabular}




\begin{tabular}{|c|c|c|c|c|}
\hline Stat & Kvalifikasjonsbevis & $\begin{array}{l}\text { Organ som utsteder } \\
\text { kvalifikasjonsbeviset }\end{array}$ & $\begin{array}{l}\text { Attest som ledsager } \\
\text { kvalifikasjonsbeviset }\end{array}$ & $\begin{array}{l}\text { Akademisk } \\
\text { referanseår }\end{array}$ \\
\hline & $\begin{array}{l}\text { - Laurea specialistica in } \\
\text { ingegneria edile }- \text { architettura }\end{array}$ & $\begin{array}{ll}- & \text { Università dell'Aquilla } \\
- & \text { Università di Pavia } \\
- & \text { Università di Roma «La } \\
& \text { Sapienza» } \\
- & \text { Università di Ancona } \\
- & \text { Università di Basilicata - } \\
& \text { Potenza } \\
- & \text { Università di Pisa } \\
- & \text { Università di Bologna } \\
- & \text { Università di Catania } \\
- & \text { Università di Genova } \\
- & \text { Università di Palermo } \\
- & \text { Università di Napoli Federico } \\
& \text { II } \\
- & \text { Università di Roma - Tor } \\
& \text { Vergata } \\
- & \text { Università di Trento } \\
- & \text { Politecnico di Bari } \\
- & \text { Politecnico di Milano }\end{array}$ & $\begin{array}{l}\text { Diploma di abilitazione } \\
\text { all'esercizo indipendente della } \\
\text { professione che viene rilasciato } \\
\text { dal ministero della Pubblica } \\
\text { istruzione dopo che il candidato } \\
\text { ha sostenuto con esito positivo } \\
\text { l'esame di Stato davanti ad una } \\
\text { commissione competente }\end{array}$ & $2003 / 2004$ \\
\hline & $\begin{array}{l}\text { Laurea specialistica } \\
\text { quinquennale in Architettura } \\
-\quad \text { Laurea specialistica } \\
\text { quinquennale in Architettura } \\
-\quad \text { Laurea specialistica } \\
\text { quinquennale in Architettura } \\
-\quad \text { Laurea specialistica in } \\
\text { Architettura }\end{array}$ & $\begin{array}{ll}- & \begin{array}{l}\text { Prima Facoltà di Architettura } \\
\text { dell’Università di Roma «La }\end{array} \\
& \text { Sapienza» } \\
- & \text { Università di Ferrara } \\
- & \text { Università di Genova } \\
- & \text { Università di Palermo } \\
- & \text { Politecnico di Milano } \\
- & \text { Politecnico di Bari } \\
- & \text { Università di Roma III } \\
- & \text { Università di Firenze } \\
- & \text { Università di Napoli II } \\
- & \text { Politecnico di Milano II }\end{array}$ & $\begin{array}{l}\text { Diploma di abilitazione } \\
\text { all'esercizo indipendente della } \\
\text { professione che viene rilasciato } \\
\text { dal ministero della Pubblica } \\
\text { istruzione dopo che il candidato } \\
\text { ha sostenuto con esito positivo } \\
\text { l'esame di Stato davanti ad una } \\
\text { commissione competente } \\
\text { Diploma di abilitazione } \\
\text { all'esercizo indipendente della } \\
\text { professione che viene rilasciato } \\
\text { dal ministero della Pubblica } \\
\text { istruzione dopo che il candidato } \\
\text { ha sostenuto con esito positivo } \\
\text { l'esame di Stato davanti ad una } \\
\text { commissione competente } \\
\text { Diploma di abilitazione } \\
\text { all'esercizo indipendente della } \\
\text { professione che viene rilasciato } \\
\text { dal ministero della Pubblica } \\
\text { istruzione dopo che il candidato } \\
\text { ha sostenuto con esito positivo } \\
\text { l'esame di Stato davanti ad una } \\
\text { commissione competente } \\
\text { Diploma di abilitazione } \\
\text { all'esercizo indipendente della } \\
\text { professione che viene rilasciato } \\
\text { dal ministero della Pubblica } \\
\text { istruzione dopo che il candidato } \\
\text { ha sostenuto con esito positivo } \\
\text { l'esame di Stato davanti ad una } \\
\text { commissione competente }\end{array}$ & $\begin{array}{l}1998 / 1999 \\
1999 / 2000 \\
2003 / 2004 \\
2004 / 2005\end{array}$ \\
\hline \multirow[t]{2}{*}{ Nederland } & $\begin{array}{l}\text { 1. Het getuigschrift van het met } \\
\text { goed gevolg afgelegde doctoraal } \\
\text { examen van de studierichting } \\
\text { bouwkunde, afstudeerrichting } \\
\text { architectuur }\end{array}$ & 1. Technische Universiteit te Delft & $\begin{array}{l}\text { Verklaring van de Stichting } \\
\text { Bureau Architectenregister die } \\
\text { bevestigt dat de opleiding voldoet } \\
\text { aan de normen van artikel } 46 \text {. }\end{array}$ & $1988 / 1989$ \\
\hline & $\begin{array}{l}\text { 2. Het getuigschrift van het met } \\
\text { goed gevolg afgelegde doctoraal } \\
\text { examen van de studierichting } \\
\text { bouwkunde, differentiatie } \\
\text { architectuur en urbanistiek }\end{array}$ & $\begin{array}{l}\text { 2. Technische Universiteit te } \\
\text { Eindhoven }\end{array}$ & & \\
\hline
\end{tabular}




\begin{tabular}{|c|c|c|c|c|}
\hline Stat & Kvalifikasjonsbevis & $\begin{array}{l}\text { Organ som utsteder } \\
\text { kvalifikasjonsbeviset }\end{array}$ & $\begin{array}{l}\text { Attest som ledsager } \\
\text { kvalifikasjonsbeviset }\end{array}$ & $\begin{array}{l}\text { Akademisk } \\
\text { referanseår }\end{array}$ \\
\hline & $\begin{array}{l}\text { 3. Het getuigschrift hoger } \\
\text { beroepsonderwijs, op grond van } \\
\text { het met goed gevolg afgelegde } \\
\text { examen verbonden aan de } \\
\text { opleiding van de tweede fase } \\
\text { voor beroepen op het terrein van } \\
\text { de architectuur, afgegeven door } \\
\text { de betrokken examencommissies } \\
\text { van respectievelijk: } \\
\text { - de Amsterdamse Hogeschool } \\
\text { voor de Kunsten te Amsterdam } \\
-\quad \text { de Hogeschool Rotterdam en } \\
\text { omstreken te Rotterdam } \\
-\quad \text { de Hogeschool Katholieke } \\
\text { Leergangen te Tilburg } \\
-\quad \text { de Hogeschool voor de } \\
\text { Kunsten te Arnhem } \\
-\quad \text { de Rijkshogeschool } \\
\text { Groningen te Groningen } \\
\text { - de Hogeschool Maastricht te } \\
\text { Maastricht }\end{array}$ & & & \\
\hline \multirow[t]{6}{*}{ Österreich } & 1. Diplom-Ingenieur, Dipl.-Ing. & $\begin{array}{l}\text { 1. Technische Universität } \\
\text { Graz (Erzherzog-Johann- } \\
\text { Universität Graz) }\end{array}$ & & 1998/1999 \\
\hline & $\begin{array}{l}\text { 2. Dilplom-Ingenieur, } \\
\text { Dipl.-Ing. }\end{array}$ & 2. Technische Universität Wien & & \\
\hline & 3. Diplom-Ingenieur, Dipl.-Ing. & $\begin{array}{l}\text { 3. Universität Innsbruck } \\
\text { (Leopold-Franzens- } \\
\text { Universität Innsbruck) }\end{array}$ & & \\
\hline & $\begin{array}{l}\text { 4. Magister der Architektur, } \\
\text { Magister architecturae, } \\
\text { Mag. Arch. }\end{array}$ & $\begin{array}{l}\text { 4. Hochschule für Angewandte } \\
\text { Kunst in Wien }\end{array}$ & & \\
\hline & $\begin{array}{l}\text { 5. Magister der Architektur, } \\
\text { Magister architecturae, } \\
\text { Mag. Arch. }\end{array}$ & $\begin{array}{l}\text { 5. Akademie der Bildenden } \\
\text { Künste in Wien }\end{array}$ & & \\
\hline & $\begin{array}{l}\text { 6. Magister der Architektur, } \\
\text { Magister architecturae, } \\
\text { Mag. Arch. }\end{array}$ & $\begin{array}{l}\text { 6. Hochschule für künstlerishe } \\
\text { und industrielle Gestaltung in } \\
\text { Linz }\end{array}$ & & \\
\hline Portugal & $\begin{array}{l}\text { Carta de curso de licenciatura em } \\
\text { Arquitectura } \\
\text { Para os cursos iniciados a partir } \\
\text { do ano académico de 1991/92 }\end{array}$ & $\begin{array}{l}\text { - Faculdade de arquitectura } \\
\text { da Universidade técnica de } \\
\text { Lisboa } \\
\text { - Faculdade de arquitectura da } \\
\text { Universidade do Porto } \\
\text { - Escola Superior Artística do } \\
\text { Porto } \\
\text { - Faculdade de Arquitectura } \\
\text { e Artes da Universidade } \\
\text { Lusíada do Porto }\end{array}$ & & $\begin{array}{l}1988 / 1989 \\
1991 / 1992\end{array}$ \\
\hline Suomi/Finland & $\begin{array}{l}\text { Arkkitehdin tutkinto/ } \\
\text { Arkitektexamen }\end{array}$ & $\begin{array}{ll}\text { - } & \begin{array}{l}\text { Teknillinen } \\
\text { Tekniska korkeakoulu/ } \\
\text { högskolan }\end{array} \\
\text { (Helsinki) } & \\
\text { - } & \text { Tampereen teknillinen } \\
& \text { korkeakoulu/Tammerfors } \\
& \text { tekniska högskola } \\
- & \begin{array}{l}\text { Oulun yliopisto/Uleåborgs } \\
\text { universitet }\end{array}\end{array}$ & & 1998/1999 \\
\hline Sverige & Arkitektexamen & $\begin{array}{l}\text { Chalmers Tekniska Högskola AB } \\
\text { Kungliga Tekniska Högskolan } \\
\text { Lunds Universitet }\end{array}$ & & 1998/1999 \\
\hline
\end{tabular}




\begin{tabular}{|c|c|c|c|c|}
\hline Stat & Kvalifikasjonsbevis & $\begin{array}{l}\text { Organ som utsteder } \\
\text { kvalifikasjonsbeviset }\end{array}$ & $\begin{array}{l}\text { Attest som ledsager } \\
\text { kvalifikasjonsbeviset }\end{array}$ & $\begin{array}{l}\text { Akademisk } \\
\text { referanseår }\end{array}$ \\
\hline United Kingdom & $\begin{array}{l} \\
\text { 2. Degrees in architecture } \\
\text { 3. Final examination } \\
\text { 4. Examination in architecture } \\
\text { 5. Examination Part II } \\
\end{array}$ & 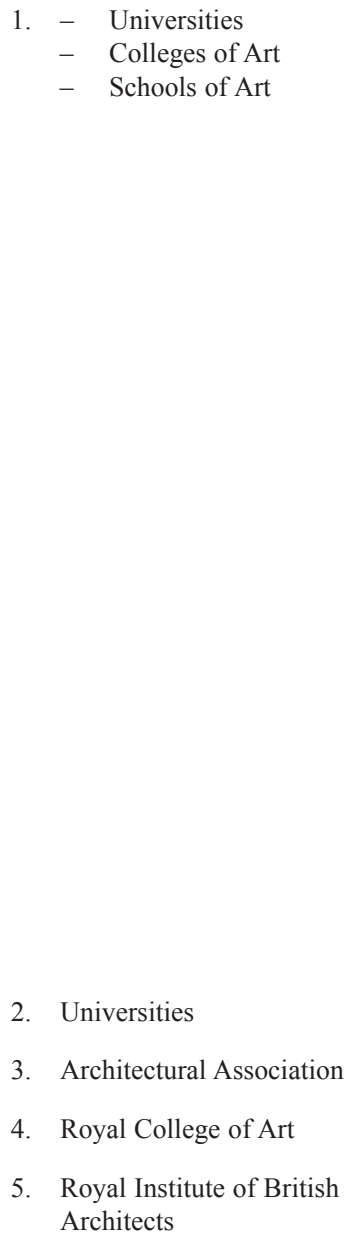 & $\begin{array}{l}\text { Certificate of architectural } \\
\text { education, issued by the } \\
\text { Architects Registration Board. } \\
\text { The diploma and degree courses } \\
\text { in architecture of the universities, } \\
\text { schools and colleges of art should } \\
\text { have met the requisite threshold } \\
\text { standards as laid down in Article } \\
46 \text { of this Directive and in Criteria } \\
\text { for validation published by the } \\
\text { Validation Panel of the Royal } \\
\text { Institute of British Architects and } \\
\text { the Architects Registration Board. } \\
\text { EU nationals who possess } \\
\text { the Royal Institute of British } \\
\text { Architects Part I and Part II } \\
\text { certificates, which are recognised } \\
\text { by ARB as the competent } \\
\text { authority, are eligible. Also EU } \\
\text { nationals who do not possess the } \\
\text { ARB-recognised Part I and Part } \\
\text { II certificates will be eligible for } \\
\text { the Certificate of Architectural } \\
\text { Education if they can satisfy the } \\
\text { Board that their standard and } \\
\text { length of education has met the } \\
\text { requisite threshold standards of } \\
\text { Article } 46 \text { of this Directive and of } \\
\text { the Criteria for validation. }\end{array}$ & $1988 / 1989$ \\
\hline
\end{tabular}


VEDLEGG VI

Ervervede rettigheter som gjelder yrker som omfattes av godkjenning på grunnlag av samordning av minstekrav til utdanning

6. Kvalifikasjonsbevis - arkitekter som omfattes av ervervede rettigheter $i$ henhold til artikkel $49 \mathrm{nr} .1$

\begin{tabular}{|c|c|c|}
\hline Stat & Kvalifikasjonsbevis & $\begin{array}{l}\text { Akademisk } \\
\text { referanseår }\end{array}$ \\
\hline $\begin{array}{l}\text { België/Belgique/ } \\
\text { Belgien }\end{array}$ & 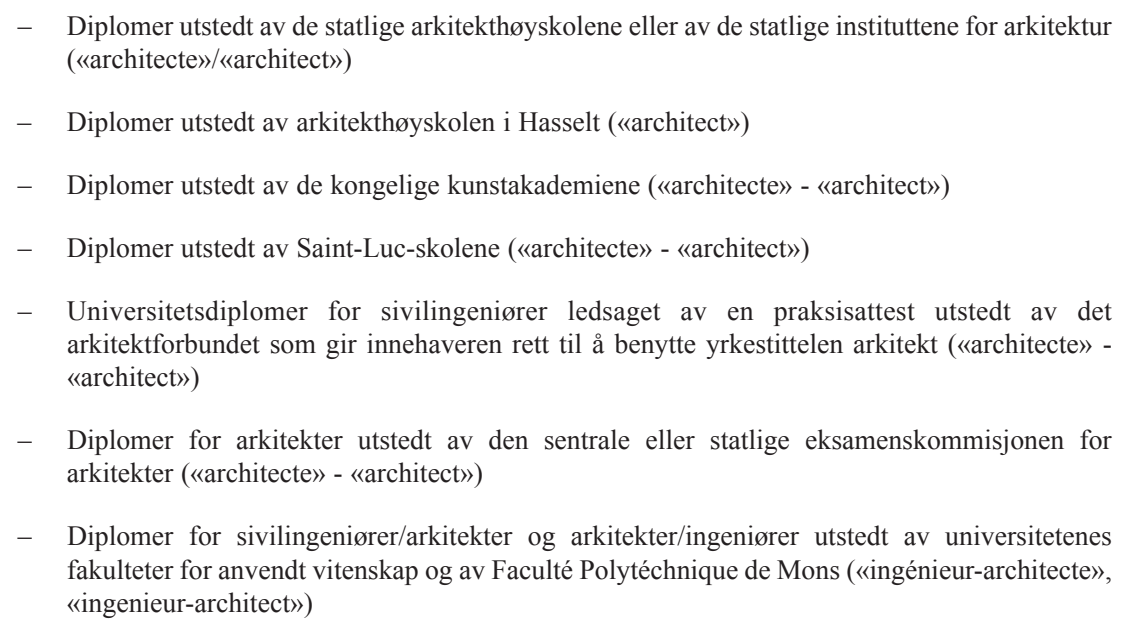 & $1987 / 1988$ \\
\hline Česká republika & 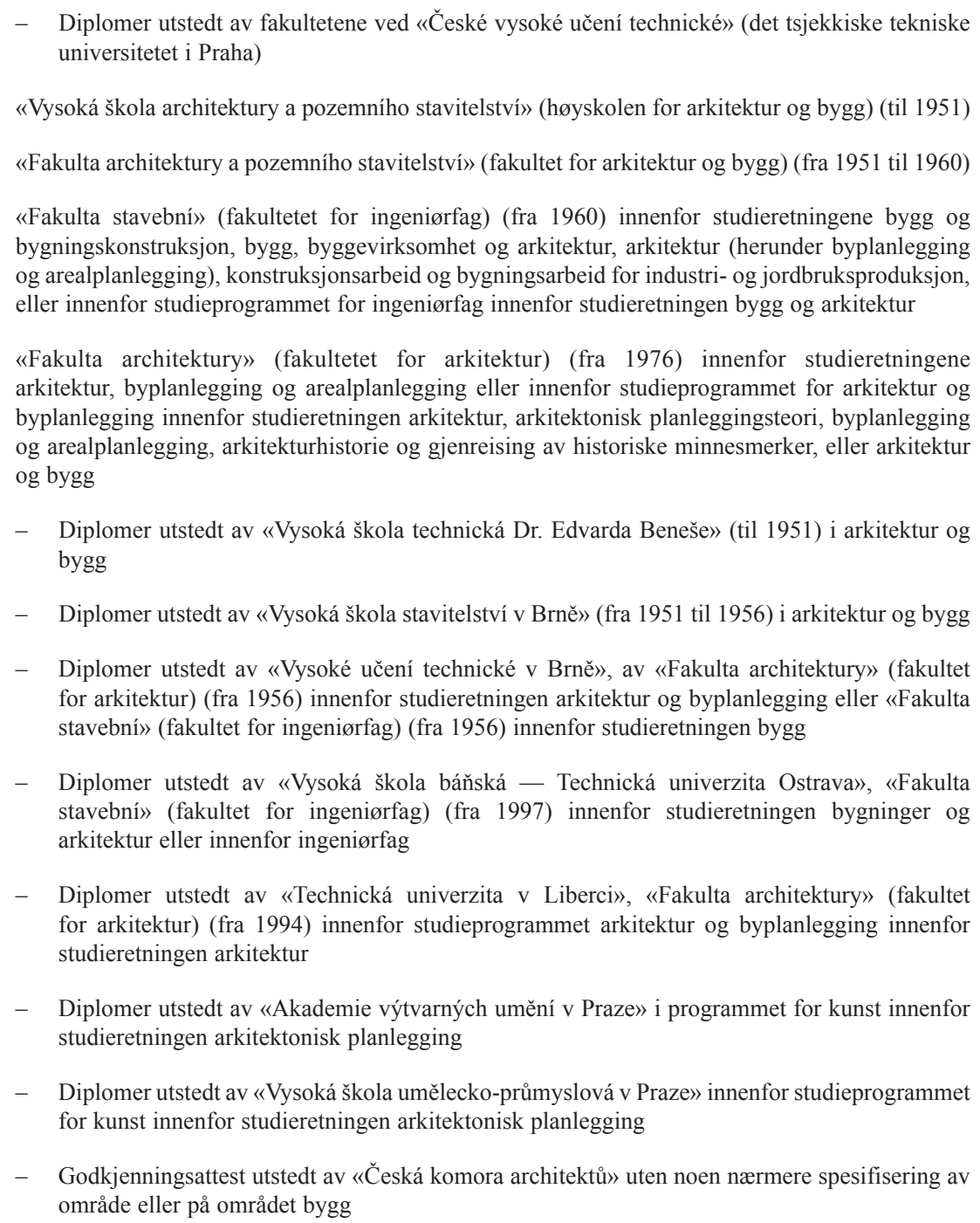 & $2006 / 2007$ \\
\hline
\end{tabular}




\begin{tabular}{|c|c|c|}
\hline Stat & Kvalifikasjonsbevis & $\begin{array}{l}\text { Akademisk } \\
\text { referanseår }\end{array}$ \\
\hline Danmark & 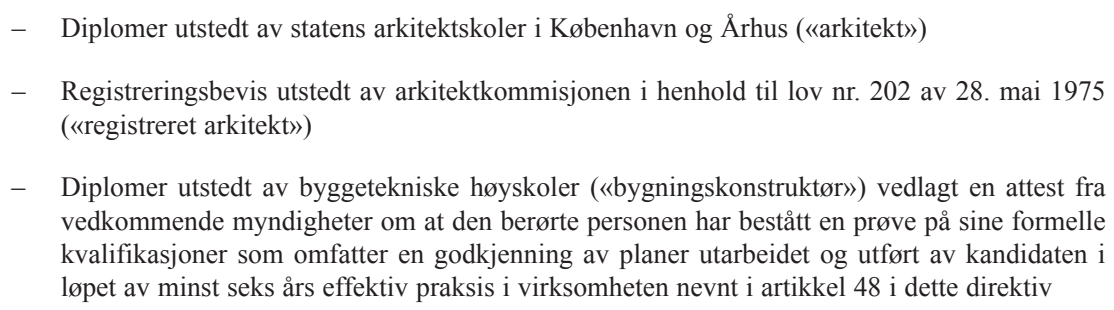 & $1987 / 1988$ \\
\hline Deutschland & $\begin{array}{l}\text { - Diplomer utstedt av kunsthøyskolene («Dipl.-Ing.», «Architekt (HfbK)») } \\
\text { - Diplomer utstedt av arkitektseksjonene («Architektur/Hochbau») ved «Technische } \\
\text { Hochschulen», av arkitektseksjonene («Architektur/Hochbau») ved tekniske universiteter, } \\
\text { av arkitektinstituttene («Architektur/Hochbau») ved universiteter og, i den utstrekning disse } \\
\text { institusjonene er slått sammen til «Gesamthochschulen», av disse «Gesamthochschulen» } \\
\text { («Dipl.-Ing.» og andre titler som senere måtte bli fastsatt for innehaverne av disse diplomene) } \\
\text { - Diplomer utstedt av arkitektseksjonene («Architektur/Hochbau») ved «Fachhochschulen } \\
\text { og i den utstrekning disse institusjoner er slått sammen til «Gesamthochschulen», av } \\
\text { arkitektseksjonene («Architektur/Hochbau») ved disse «Gesamthochschulen» og, når } \\
\text { studietiden er på under fire år, men minst tre år, ledsaget av en attest som bekrefter at } \\
\text { vedkommende har fire års yrkeserfaring i Forbundsrepublikken Tyskland, og som er utstedt av } \\
\text { bransjeorganisasjonen i samsvar med artikkel } 47 \text { nr. } 1 \text { («Ingenieur grad.» og andre titler som } \\
\text { måtte bli fastsatt senere for innehaverne av disse diplomene) } \\
\text { Diplomer («Prüfungszeugnisse») utstedt før 1. januar } 1973 \text { av arkitektseksjonene ved } \\
\text { «Ingenieurschulen» og ved «Werkkunstschulen», ledsaget av en attest fra vedkommende } \\
\text { myndigheter om at den berørte personen har bestått en prøve på sine formelle kvalifikasjoner } \\
\text { som omfatter en godkjenning av planer utarbeidet og utført av kandidaten i løpet av minst seks } \\
\text { års effektiv praksis i de former for virksomhet som er nevnt i artikkel } 48 \text { i dette direktiv }\end{array}$ & $1987 / 1988$ \\
\hline Eesti & $\begin{array}{l}\text { - «Diplom arhitektuuri erialal, väljastatud Eesti Kunstiakadeemia arhitektuuri teaduskonna poolt } \\
\text { alates 1996. aastast» (diplom i arkitektur utstedt av fakultetet for arkitektur ved det estiske } \\
\text { kunstakademiet etter 1996), «väljastatud Tallinna Kunstiülikooli poolt 1989-1995» (utstedt av } \\
\text { kunsthøyskolen i Tallinn i 1989-1995), «väljastatud Eesti NSV Riikliku Kunstiinstituudi poolt } \\
\text { 1951-1988» (utstedt av statens kunstinstitutt i Estland SSR i 1951-1988) }\end{array}$ & $2006 / 2007$ \\
\hline $\mathrm{E} \lambda \lambda \alpha \dot{\alpha} \varsigma$ & 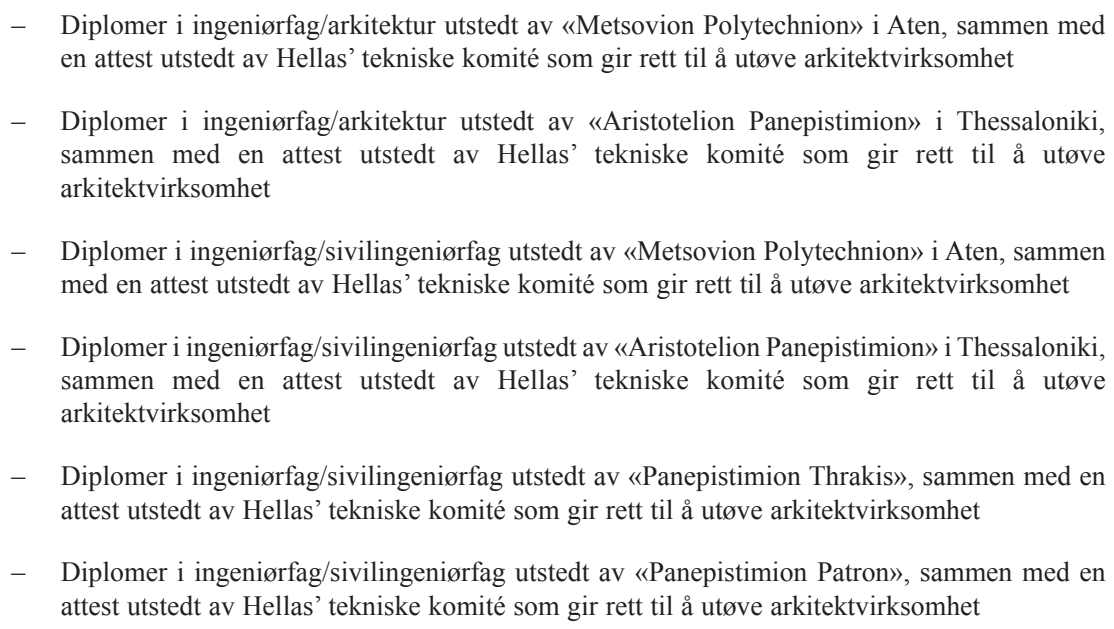 & $1987 / 1988$ \\
\hline España & $\begin{array}{l}\text { Offisiell formell kvalifikasjon som arkitekt («título oficial de arquitecto») utstedt av departementet } \\
\text { for utdanning og vitenskap eller av universitetene }\end{array}$ & $1987 / 1988$ \\
\hline
\end{tabular}




\begin{tabular}{|c|c|c|}
\hline Stat & Kvalifikasjonsbevis & $\begin{array}{l}\text { Akademisk } \\
\text { referanseår }\end{array}$ \\
\hline France & 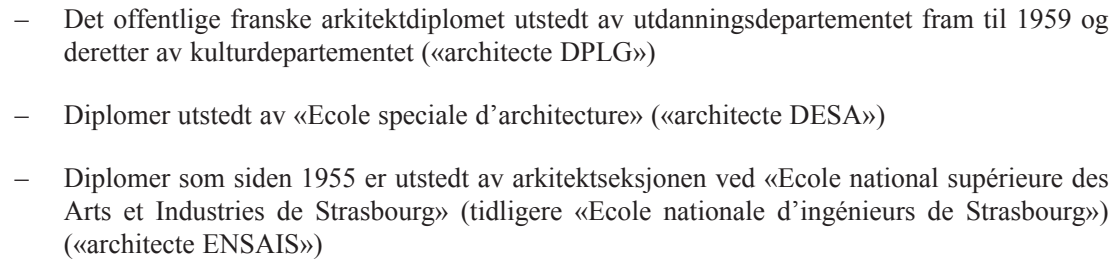 & $1987 / 1988$ \\
\hline Ireland & 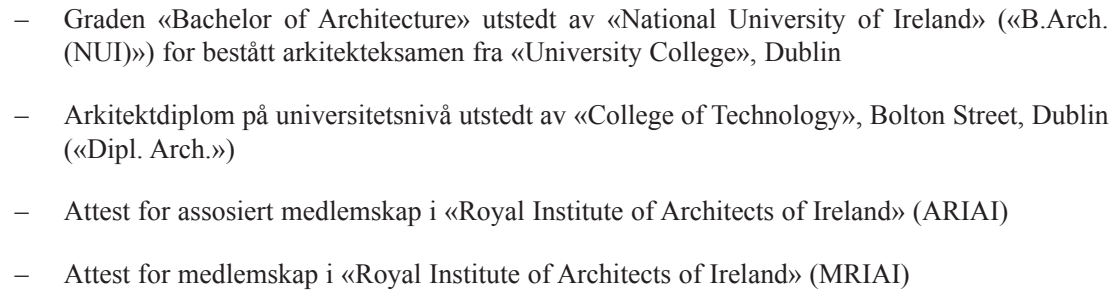 & $1987 / 1988$ \\
\hline Italia & $\begin{array}{l}\text { - Diplomene «laurea in architettura» utstedt av universitetene, de polytekniske instituttene } \\
\text { og arkitekthøyskolene i Venezia og Reggio-Calabria, ledsaget av diplomet som gir rett til } \\
\text { selvstendig utøvelse av arkitektyrket, utstedt av undervisningsministeren etter at kandidaten } \\
\text { har bestått den offentlige eksamenen avlagt for en sakkyndig eksamenskommisjon som gir rett } \\
\text { til selvstendig utøvelse av arkitektyrket («dott. Architetto») } \\
\text { - Diplomene «laurea in ingegneria» i bygningskonstruksjon, utstedt av universitetene og de } \\
\text { polytekniske instituttene, ledsaget av diplom som gir rett til selvstendig utøvelse av et yrke } \\
\text { innenfor arkitektvirksomhet, utstedt av undervisningsministeren etter at kandidaten har bestått } \\
\text { en offentlig eksamen avlagt for en sakkyndig eksamenskommisjon, som gir rett til selvstendig } \\
\text { utøvelse av yrket («dott. Ing. Architetto» eller «dott. in ingegneria civile») }\end{array}$ & $1987 / 1988$ \\
\hline Kú $\pi \rho \circ \varsigma$ & 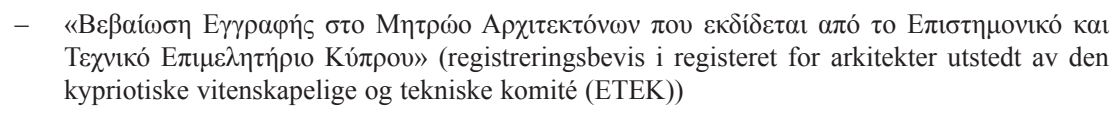 & $2006 / 2007$ \\
\hline Latvija & $\begin{array}{l}\text { - «Arhitekta diploms«» ko izsniegusi Latvijas Valsts Universitātes Inženierceltniecības } \\
\text { fakultātes Arhitektūras nodal̦a līdz 1958.gadam, Rīgas Politehniskā Institūta Celtniecības } \\
\text { fakultātes Arhitektūras nodal̦a no } 1958 \text { gada līdz 1991.gadam, Rīgas Tehniskās Universitātes } \\
\text { Arhitektūras fakultāte kopš 1991. gada, un «Arhitekta prakses sertifikāts», ko izsniedz Latvijas } \\
\text { Arhitektu savienība («arkitektdiplom» utstedt av avdeling for arkitektur ved fakultetet for } \\
\text { ingeniørfag ved Latvias statsuniversitet fram til 1958, av avdeling for arkitektur ved fakultetet } \\
\text { for ingeniørfag ved det polytekniske institutt i Riga fra } 1958 \text { til 1991, av fakultetet for } \\
\text { arkitektur ved det tekniske universitetet i Riga etter } 1991 \text { og } 1992 \text { samt registreringsattest fra } \\
\text { den latviske yrkessammenslutningen for arkitekter) }\end{array}$ & $2006 / 2007$ \\
\hline Lietuva & 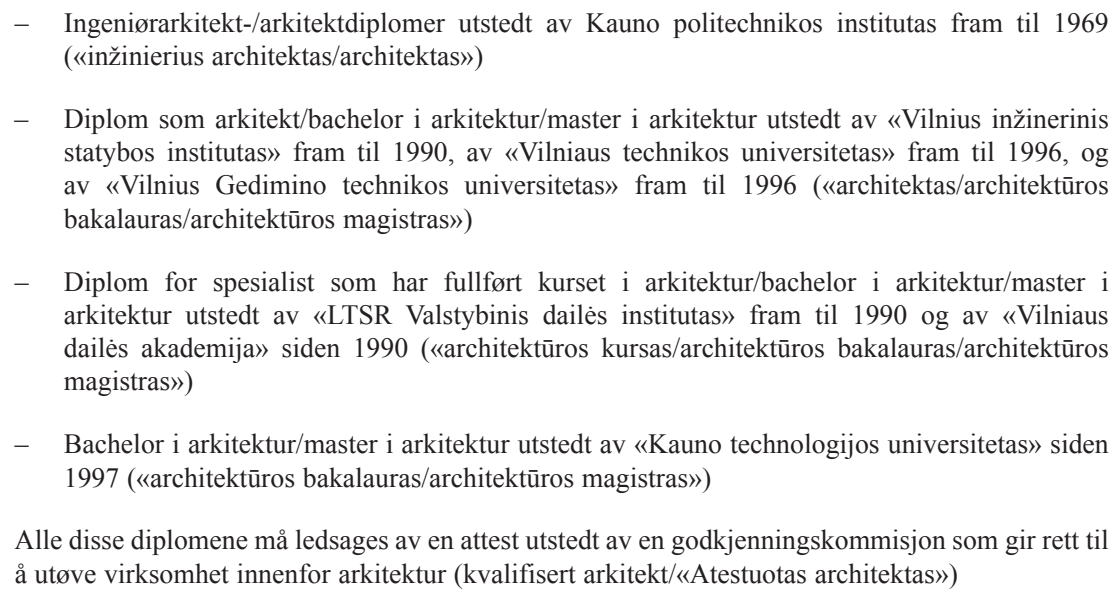 & $2006 / 2007$ \\
\hline
\end{tabular}




\begin{tabular}{|c|c|c|}
\hline Stat & Kvalifikasjonsbevis & $\begin{array}{l}\text { Akademisk } \\
\text { referanseår }\end{array}$ \\
\hline Magyarország & $\begin{array}{l}\text { - Diplomet «okleveles építészmérnök» (diplom i arkitektur, master i arkitekturvitenskap) utstedt } \\
\text { av universitetene } \\
\text { - Diplomet «okleveles építész tervezõ mûvész» (diplom for en master i arkitekturvitenskap og } \\
\text { bygningsingeniørfag) utstedt av universitetene }\end{array}$ & $2006 / 2007$ \\
\hline Malta & $\begin{array}{l}\text { - «Perit: Lawrja ta’ Perit» utstedt av «Universita’ ta’ Malta» som gir rett til registrering som } \\
\text { «Perit» }\end{array}$ & $2006 / 2007$ \\
\hline Nederland & 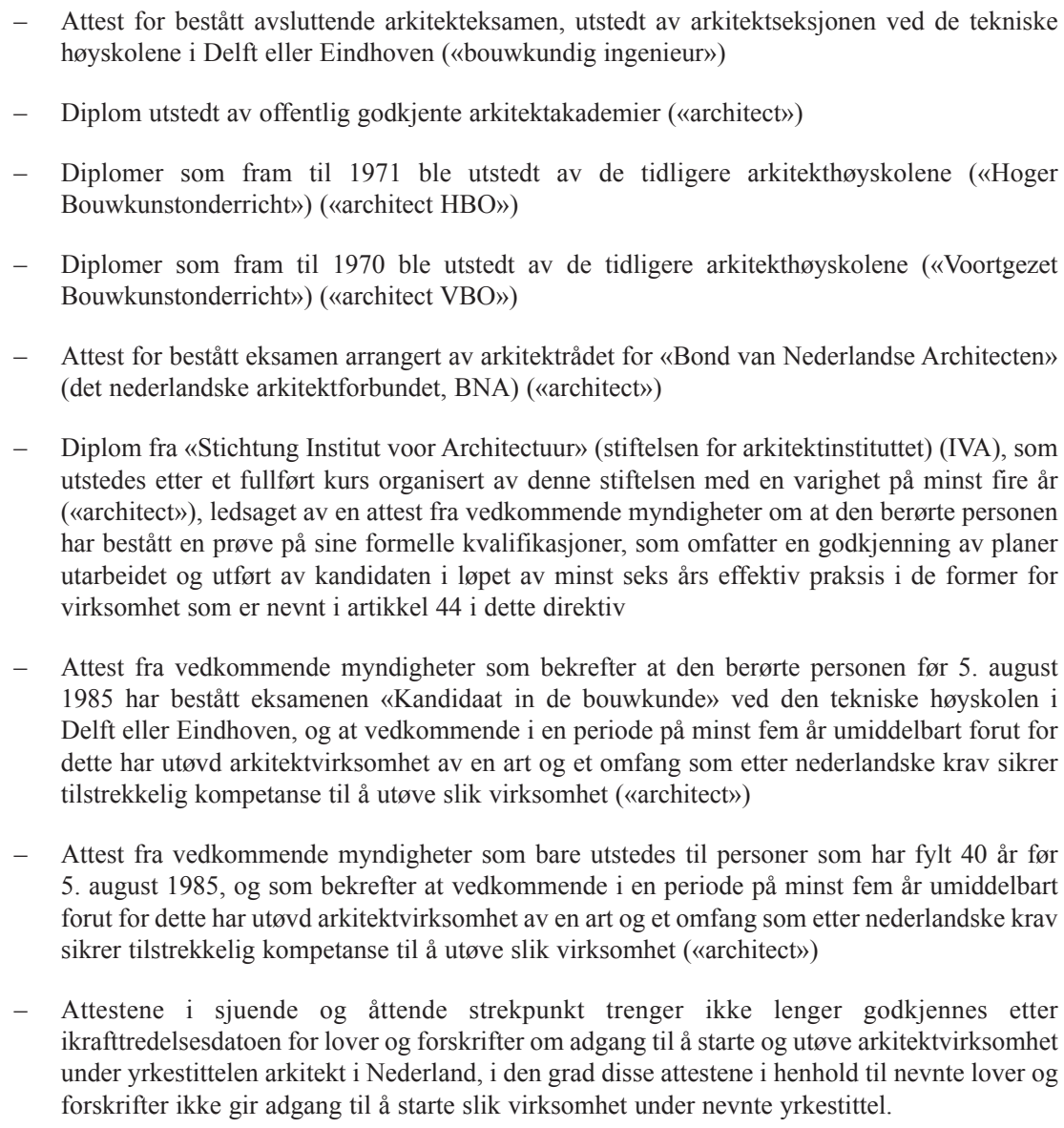 & $1987 / 1988$ \\
\hline Österreich & 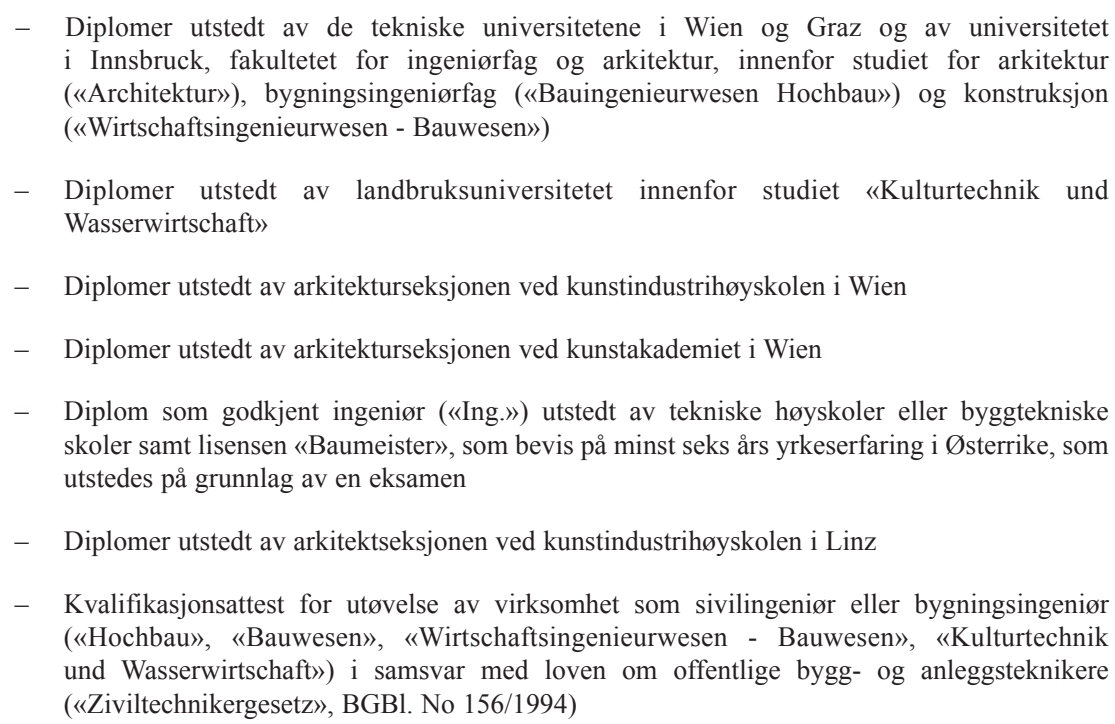 & $1997 / 1998$ \\
\hline
\end{tabular}




\begin{tabular}{l|l|l}
\hline \multicolumn{1}{c|}{ Stat } & \multicolumn{1}{c}{ Kvalifikasjonsbevis } & $\begin{array}{c}\text { Akademisk } \\
\text { referanseår }\end{array}$ \\
\hline Polska & $\begin{array}{l}\text { Diplomer utstedt av fakultetet for arkitektur ved } \\
-\quad \text { Warszawa tekniske universitet, fakultet for arkitektur i Warszawa («Politechnika Warszawska, }\end{array}$ & $2006 / 2007$
\end{tabular}

Wydział Architektury»), yrkestitler for arkitekter: «inżynier architekt», «magister nauk technicznych», «inżynier architekt», «inżyniera magistra architektury», «magistra inżyniera architektury», «magistra inżyniera architekta», «magister inżynier architekt» (fra 1945 til 1948 med tittel «inżynier architekt», «magister nauk technicznych», fra 1951 til 1956 med tittel «inżynier architekt», fra 1954 til 1957, 2. avdeling med tittel «inżyniera magistra architektury», fra 1957 til 1959 med tittel «inżyniera magistra architektury», fra 1959 til 1964 med tittel «magistra inżyniera architektury», fra 1964 til 1982 med tittel «magistra inżyniera architekta», fra 1983 til 1990 med tittel «magister inżynier architekt», etter 1991 med tittel «magistra inżyniera architekta»)

- Krakovs tekniske universitet, fakultet for arkitektur i Krakov («Politechnika Krakowska, Wydział Architektury»), yrkestitler for arkitekter: «magister inżynier architekt» (fra 1945 til 1953 ved universitetet for gruvedrift og metallurgi, polyteknisk fakultet for arkitektur «Akademia Górniczo-Hutnicza, Politechniczny Wydział Architektury»)

- Wrocław tekniske universitet, fakultet for arkitektur i Wrocław («Politechnika Wrocławska, Wydział Architektury»); yrkestitler for arkitekter: «inżynier architekt», «magister nauk technicznych», «magister inżynier architektury», «magister inżynier architekt» (fra 1949 til 1964 med tittel «inżynier architekt», «magister nauk technicznych», fra 1956 til 1964 med tittel «magister inżynier architektury», etter 1964 med tittel «magister inżynier architekt»)

- Det tekniske universitetet i Schlesien, fakultet for arkitektur i Gliwice («Politechnika Śląska, Wydział Architektury»), yrkestitler for arkitekter: «inżynier architekt», «magister inżynier architekt» (fra 1945 til 1955 ved fakultet for ingeniørvitenskap og bygg(«Wydział Inżynieryjno-Budowlany») med tittel «inżynier architekt», fra 1961 til 1969 ved fakultet for industribygg og allmenne ingeniørfag («Wydział Budownictwa Przemysłowego i Ogólnego») med tittel «magister inżynier architekt», fra 1969 til 1976 ved fakultet for sivilingeniørstudier og arkitektur («Wydział Budownictwa i Architektury») med tittel «magister inżynier architekt», etter 1977 ved fakultet for arkitektur («Wydział Architektury») med tittel «magister inżynier architekt» og etter 1995 med tittel «inżynier architekt»)

- Det tekniske universitetet i Poznan, fakultet for arkitektur i Poznań («Politechnika Poznańska Wydział Architektury»), yrkestitler for arkitekter: «inżynier architektury», «inżynier architekt», «magister inżynier architekt» (fra 1945 til 1955, skole for ingeniørfag, fakultet for arkitektur («Szkoła Inżynierska, Wydział Architektury») med tittel «inżynier architektury», etter 1978 med tittel «magister inżynier architekt» og etter 1999 med tittel «inżynier architekt»)

- Det tekniske universitetet i Gdańsk, fakultet for arkitektur i Gdańsk («Politechnika Gdańska, Wydział Architektury»), yrkestitler for arkitekter: «magister inżynier architekt» (fra 1945 til 1969 ved fakultet for arkitektur («Wydział Architektury»), fra 1969 til 1971 ved fakultet for sivilingeniørfag og arkitektur («Wydział Budownictwa i Architektury»), fra 1971 til 1981 ved institutt for arkitektur og byplanlegging («Instytut Architektury i Urbanistyki») og etter 1981 ved fakultet for arkitektur («Wydział Architektury»))

- Det tekniske universitetet i Białystok, fakultet for arkitektur i Białystok («Politechnika Białostocka, Wydział Architektury»), yrkestitler for arkitekter: «magister inżynier architekt» (fra 1975 til 1989 ved institutt for arkitektur («Instytut Architektury»))

- Det tekniske universitetet i Łódź, fakultet for sivilingeniørfag, arkitektur og miljøteknologi i Łódź («Politechnika Łódzka, Wydział Budownictwa, Architektury i Inżynierii Środowiska»), yrkestitler for arkitekter: «inżynier architekt», «magister inżynier architekt» (fra 1973 til 1993 ved fakultet for sivilingeniørfag og arkitektur («Wydział Budownictwa i Architektury») og etter 1992 ved fakultet for sivilingeniørfag, arkitektur og miljøteknologi («Wydział Budownictwa, Architektury i Inżynierii Środowiska»), fra 1973 til 1978 med tittel «inżynier architekt», etter 1978 med tittel «magister inżynier architekt»)

- Det tekniske universitetet i Szczecin, fakultet for sivilingeniørfag og arkitektur i Szczecin («Politechnika Szczecińska, Wydział Budownictwa i Architektury»), yrkestitler for arkitekter: «inżynier architekt»; «magister inżynier architekt» (fra 1948 til 1954 ved høyskolen for ingeniørfag, fakultet for arkitektur «Wyższa Szkoła Inżynierska, Wydział Architektury») med tittel «inżynier architekt», etter 1970 med tittel «magister inżynier architekt» og etter 1998 med tittel «inżynier architekt»)

Alle disse diplomene må ledsages av en attest på medlemskap utstedt av vedkommende regionalt arkitektorgan i Polen som gir rett til å utøve arkitektvirksomhet i Polen. Porto

- Arkitektdiplomet «diploma de arquitecto» utstedt av kunstskolene i Lisboa og i Porto

- Diplomet «diploma do curso de arquitectura» utstedt av kunsthøyskolene i Lisboa og i Porto 


\begin{tabular}{|c|c|c|}
\hline Stat & Kvalifikasjonsbevis & $\begin{array}{l}\text { Akademisk } \\
\text { referanseår }\end{array}$ \\
\hline & $\begin{array}{l}\text { - Diplomet «diploma de licenciatura em arquitectura» utstedt av kunsthøyskolen i Lisboa } \\
\text { _ } \quad \text { Diplomet «carta de curso de licenciatura em arquitectura» utstedt av det tekniske universitetet } \\
\text { i Lisboa og universitetet i Porto } \\
\text { - } \quad \text { Universitetsdiplom i sivilingeniørfag («licenciatura em engenharia civil») utstedt av teknisk } \\
\text { institutt ved det tekniske universitetet i Lisboa } \\
\text { - } \quad \text { Universitetsdiplom i sivilingeniørfag («licenciatura em engenharia civil») utstedt av fakultetet } \\
\text { for ingeniørfag («de Engenharia») ved universitetet i Porto } \\
-\quad \text { Universitetsdiplom i sivilingeniørfag («licenciatura em engenharia civil») utstedt av fakultetet } \\
\text { for vitenskap og teknologi ved universitetet i Coimbra } \\
\text { - Universitetsdiplom i sivilingeniørfag og produksjon («licenciatura em engenharia civil, } \\
\text { produção») utstedt av universitetet i Minho }\end{array}$ & \\
\hline Slovenija & $\begin{array}{l}\text { - «Univerzitetni diplomirani inženir arhitekture/univerzitetna diplomirana inženirka arhitekture» } \\
\text { (universitetsdiplom i arkitektur) utstedt av fakultet for arkitektur, ledsaget av en attest fra en } \\
\text { juridisk godkjent vedkommende myndighet innenfor arkitektur gir rett til å utøve virksomhet } \\
\text { på området arkitektur } \\
\text { - Universitetsdiplom utstedt av teknisk fakulteter som gir rett til tittelen «univerzitetni } \\
\text { diplomirani inženir (univ.dipl.inž.)»/«univerzitetna diplomirana inženirka», ledsaget av en } \\
\text { attest fra en juridisk godkjent vedkommende myndighet innenfor arkitektur gir rett til å utøve } \\
\text { virksomhet på området arkitektur }\end{array}$ & $2006 / 2007$ \\
\hline Slovensko & 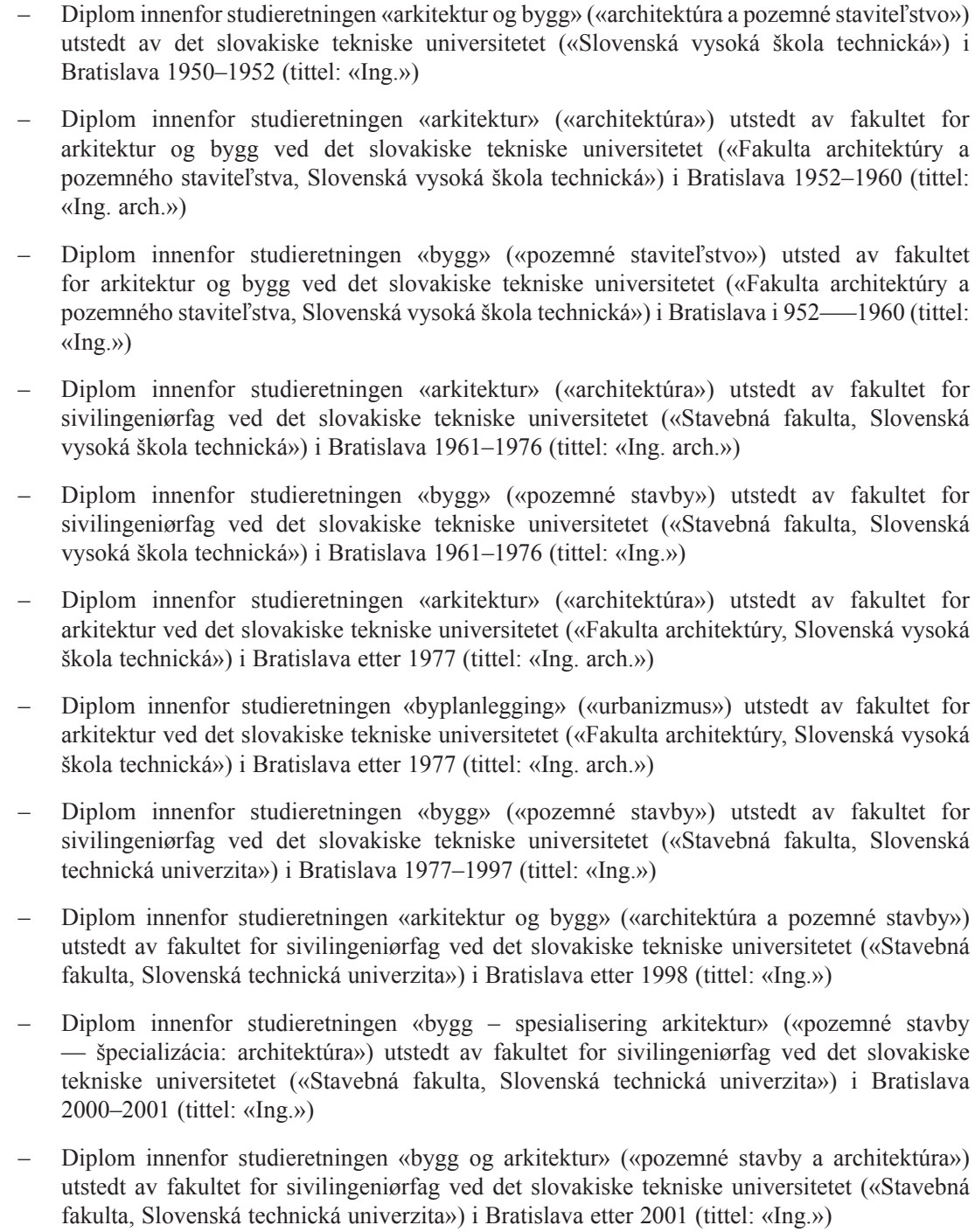 & $2006 / 2007$ \\
\hline
\end{tabular}




\begin{tabular}{|c|c|c|}
\hline Stat & Kvalifikasjonsbevis & $\begin{array}{l}\text { Akademisk } \\
\text { referanseår }\end{array}$ \\
\hline & 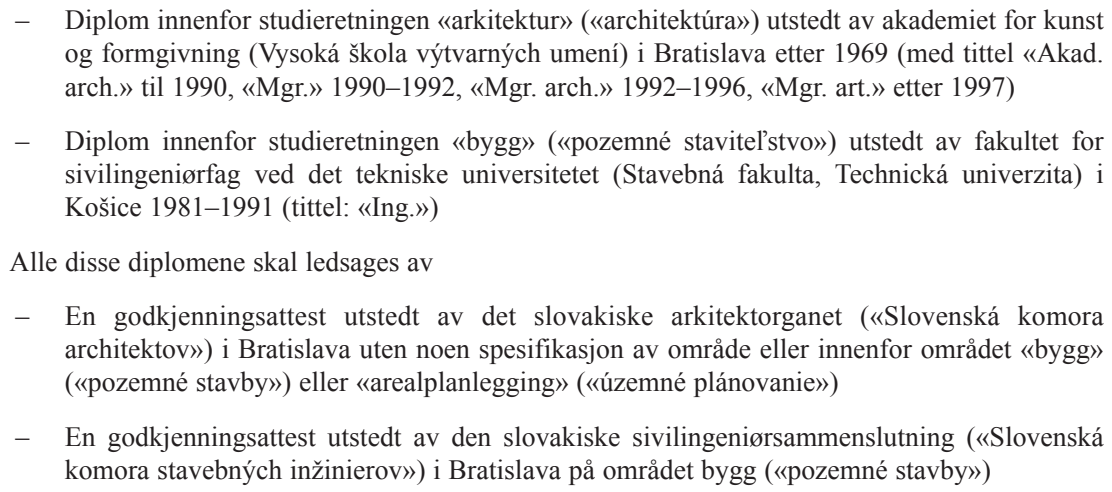 & \\
\hline Suomi/Finland & $\begin{array}{l}\text { - Diplomer utstedt av avdelingene for arkitektur ved de tekniske universitetene og universitet i } \\
\text { Oulu («arkkitehti»/«arkitekt») } \\
\text { - } \quad \text { Diplomer utstedt av de tekniske instituttene («rakennusarkkitehti»//«byggnadsarkitekt») }\end{array}$ & $1997 / 1998$ \\
\hline Sverige & 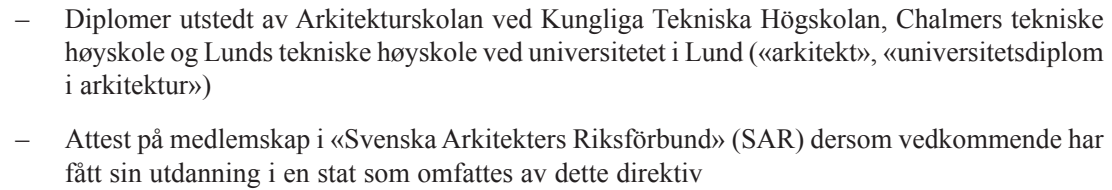 & $1997 / 1998$ \\
\hline United Kingdom & $\begin{array}{l}\text { - Kvalifikasjonsbevis utstedt etter bestått eksamen ved } \\
\text { - } \quad \text { «Royal Institute of British Architects» } \\
\text { - } \quad \text { Arkitektavdelinger ved universiteter, tekniske høyskoler, colleger, akademier, tekniske } \\
\text { skoler og kunstskoler som per 10. juni } 1985 \text { var godkjent av «Architects Registration } \\
\text { Council» i Det forente kongerike med henblikk på opptak i arkitektregisteret («architect») } \\
\text { - En attest på at innehaveren har en ervervet rett til å bruke yrkestittelen arkitekt i henhold til } \\
\text { avsnitt } 6 \mathrm{nr} \text {. } 1 \text { bokstav a), b) eller d) i «Architects Registration Act» av } 1931 \text { («architect») } \\
-\quad \text { En attest på at innehaveren har en ervervet rett til å bruke yrkestittelen arkitekt i henhold til } \\
\text { avsnitt } 2 \mathrm{i} \text { «Architects Registration Act» av } 1938 \text { («architect») }\end{array}$ & $1987 / 1988$ \\
\hline
\end{tabular}




\section{Dokumenter og attester som kan kreves i samsvar med artikkel $50 \mathrm{nr} .1$}

1. Dokumenter

a) Bevis på vedkommendes statsborgerskap.

b) Kopier av kompetanse- eller kvalifikasjonsbeviser som gir adgang til det berørte yrket samt, der det er hensiktsmessig, en attestering av vedkommendes yrkeserfaring.

Vedkommende myndigheter i vertsstaten kan anmode søkeren om å framlegge opplysninger om utdanning i den utstrekning det er nødvendig for å fastslå om det foreligger mulige vesentlige forskjeller i forhold til den utdanningen som kreves i vertsstaten i samsvar med artikkel 14. Der det er umulig for søkeren å framlegge disse opplysningene, skal vedkommende myndigheter i vertsstaten henvende seg til kontaktpunktet, vedkommende myndighet eller annet relevant organ i hjemstaten.

c) Når det gjelder tilfellene i artikkel 16, en attest på virksomhetens art og varighet utstedt av vedkommende myndighet eller organ i hjemstaten eller i den seneste oppholdsstaten.

d) Når vedkommende myndighet i en vertsstat gjør adgang til et lovregulert yrke betinget av at søkerne framlegger bevis på god vandel eller hederlighet eller på at de ikke er erklært konkurs, eller utelukker eller forbyr utøvelse av yrket på grunn av alvorlig forsømmelse i utøvelsen eller overtredelse av straffeloven, skal denne medlemsstaten godta som tilstrekkelig bevis, når det gjelder borgere $\mathrm{i}$ andre medlemsstater som ønsker å utøve dette yrket på denne statens territorium, dokumenter utstedt av vedkommende myndigheter i hjemstaten eller den seneste oppholdsstaten som viser at disse kravene er oppfylt. Disse myndighetene skal framlegge de nødvendige dokumentene innen to måneder.

Der vedkommende myndigheter i hjemstaten eller den seneste oppholdsstaten ikke utsteder dokumentene nevnt i første ledd, kan dette erstattes av en erklæring under ed, eller i stater der det ikke er anledning til slik edsavleggelse, av en forsikring på ære og samvittighet, avgitt av den berørte personen for vedkommende retts- eller forvaltningsmyndighet, eventuelt for en notarius publicus eller et kvalifisert bransjeorgan i hjemstaten eller den seneste oppholdsstaten, som utsteder en attest som bekrefter gyldigheten av nevnte erklæring eller forsikring.

e) Dersom en vertsstat krever at egne borgere som ønsker å starte en lovregulert virksomhet, legger fram attest på vedkommendes fysiske eller psykiske helse, skal denne medlemsstaten godta som tilstrekkelig bevis det dokument som kreves i hjemstaten. I tilfeller der hjemstaten ikke utsteder et slikt dokument, skal vertsstaten godta en attest utstedt av vedkommende myndighet i denne staten. I så fall skal vedkommende myndigheter i hjemstaten framlegge de nødvendige dokumentene innen to måneder.

f) Dersom en vertsstat krever at egne borgere som ønsker å starte i et lovregulert yrke, framlegger

- bevis på søkerens finansielle stilling,

- bevis på at søkeren er forsikret mot den økonomiske risiko som er forbundet med deres yrkesansvar i samsvar med gjeldende lover og forskrifter i vertsstaten om forsikringens vilkår og dekning,

skal denne medlemsstaten godta som tilstrekkelig bevis en attest om dette utstedt av banker og forsikringsselskaper i en annen medlemsstat.

2. Attester

For å lette anvendelsen av dette direktivs avdeling III kapittel III, kan en medlemsstat bestemme at personer som oppfyller utdanningsvilkårene, i tillegg til kvalifikasjonsbevisene skal framlegge en attest fra vedkommende myndigheter i hjemstaten som bekrefter at disse kvalifikasjonsbevisene tilsvarer dem som er omhandlet i dette direktiv. 